\title{
HYDROLOGY OF THE TERTIARY-CRETACEOUS AQUIFER SYSTEM IN THE VICINITY OF FORT RUCKER AVIATION CENTER, ALABAMA
}

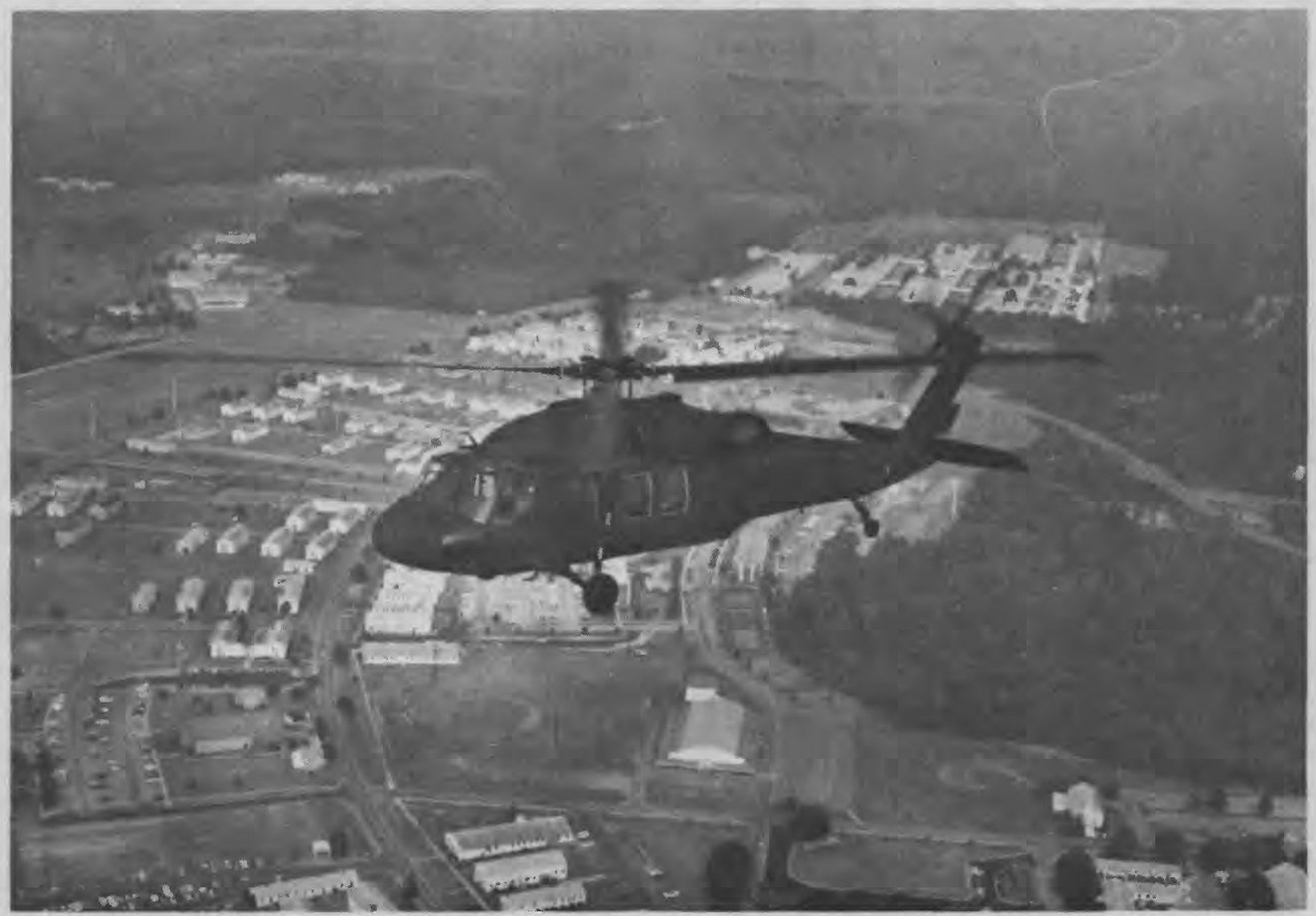

\section{U.S. GEOLOGICAL SURVEY}

Water-Resources Investigations Report 84-4118

Prepared in cooperation with the DEPARTMENT OF THE ARMY, HEADQUARTERS UNITED STATES ARMY AVIATION CENTER, AND FORT RUCKER 
Cover

Photograph courtesy of Fort Rucker Aviation Center. 
HYDROLOGY OF THE TERTIARY-CRETACEOUS AQUIFER SYSTEM

IN THE VICINITY OF FORT RUCKER AVIATION CENTER, ALABAMA

By John C. Scott, Linda R. Law, and Riley H. Cobb

U.S. GEOLOGICAL SURVEY

Water-Resources Investigations Report 84-4118

Prepared in cooperation with the

DEPARTMENT OF THE ARMY

HEADQUARTERS UNITED STATES ARMY AVIATION CENTER and FORT RUCKER 


\section{UNITED STATES DEPARTMENT OF THE INTERIOR \\ WILLIAM P. CLARK, Secretary \\ GEOLOGICAL SURVEY \\ Dallas L. Peck, Director}

For additional information write to:

District Chief

U.S. Geological Survey

520 19th Avenue

Tuscaloosa, Alabama 35401
Copies of this report can be purchased from:

Open-File Services Section

U.S. Geological Survey Box 25425, Federal Center Denver, Colorado 80225 
Abstract............................................. 1

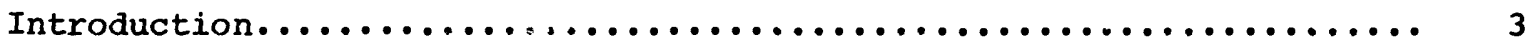

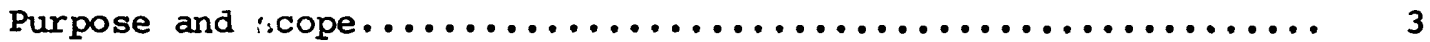

Previous geologic and hydrologic studies................. 5

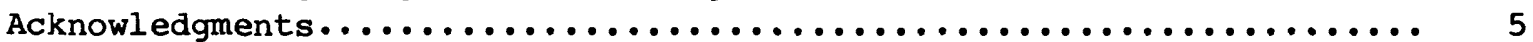

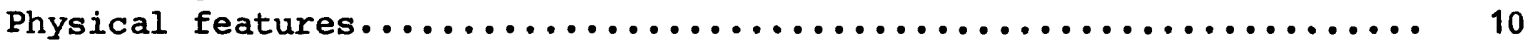

Geologic formations and their water-bearing characteristics....... 10

Ripley Formation................................... 10

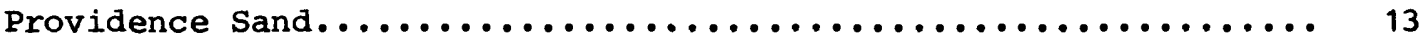

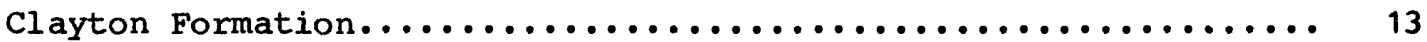

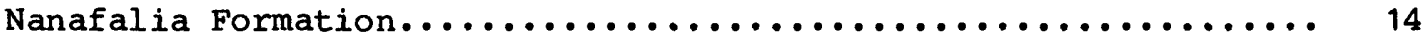

Tuscahoma sand....................................... 14

Hatchetigbee Formation...................................... 14

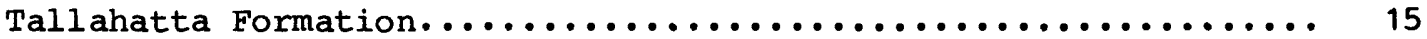

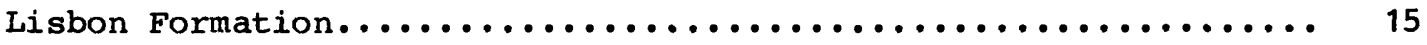

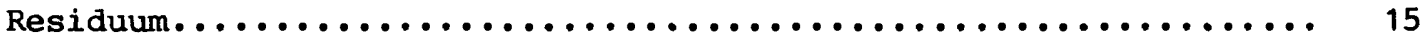

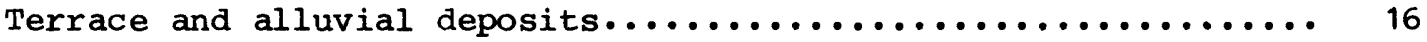

Hydrology of the Tertiary-Cretaceous aquifer system............ 16

Source of ground water............................... 16

Recharge and discharge.............................. 17

Aquifer tests....................................... 17

Withdrawals......................................... 23

Fluctuation of the potentiometric surface................. 25

Effects of withdrawals on the aquifer system.............. 27

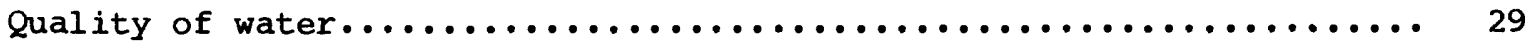

Summary ............................................ 33

Selected references........................................ 34 


\section{ILLUSTRATIONS}

Page

Figure 1. Map showing location of the area of study..............

2. Map showing locations of wells and stratigraphic cross sections.................................... 6

3. Generalized geologic map of the Cretaceous and Tertiary formations in southeastern Alabama................. 8

4. Stratigraphic cross section $A-A^{\prime}$ from Enterprise to Headland ..................................... 11

5. Stratigraphic cross section $B-B^{\prime}$ from Cairns Airfield near Fort Rucker to about three miles north of Ozark.... 12

6. Generalized cross section of the aquifer system.......... 18

7. Map showing locations of wells used in aquifer test at Fort Rucker................................... 20

8. Fence diagram of production wells at Fort Rucker in 1983... 21

9. Drawdown in wells at Fort Rucker during aquifer test...... 22

10. Theoretical arawdown in the upper aquifer at Fort Rucker... 24

11. Fluctuation of the water level in well 24 (lower aquifer), average daily pumpage at Ozark, and total monthly precipitation at Eufaula Wildlife Refuge during 1982-83.. 26

12. Water-level trends in production wells at Fort Rucker

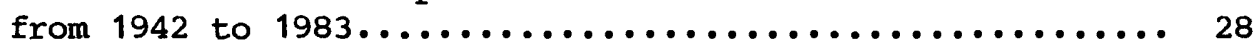

13. Map showing the potentiometric surface of the upper

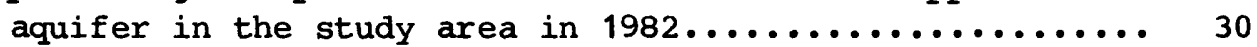

14. Areas of diversion and recharge for the upper aquifer.... 32

\section{TABLES}

Table 1. Records of wells in the Fort Rucker area............. 36

2. Sample logs of wells in the Fort Rucker area............ 75

3. Driller's logs of wells in the Fort Rucker area......... 106 
The following factors may be used to convert the Inch-pound units published herein to International system of units (SI).

Length

Multiply Inch-Pound units

inch $(i n$.

foot ( $f t)$

mile ( $\mathrm{mi}$ )

gallon per minute (gal/min)

million gallons per day

(Mga I/d) $\underline{\text { by }}$

25.4

0.3048

1. 609

Flow

0.06308

0.04381

Transmissivity

foot squared per day $\left(f t^{2} / d\right)$
0.09290
To obtain SI units

millimeter (mm)

meter (m)

kilometer $(\mathrm{km})$

liter per second (L/s) cubic meters per second $\left(\mathrm{m}^{3} / \mathrm{s}\right)$

meter squared per day $\left(\mathrm{m}^{2} / \mathrm{d}\right)$

National Geodetic Vertical Datum of 1929 (NGVD of 1929).

A geodetic datum derived from a general adjustment of the first-order level nets of both the United States and Canada, formerly called mean sea level. This datum is referred to as sea level in this report. 


\section{HYDROLOGY OF THE TERTIARY-CRETACEOUS AQUIFER SYSTEM \\ IN THE VICINITY OF THE FORT RUCKER AVIATION CENTER, ALABAMA}

By John C. Scott, Linda R. Law, and Riley H. Cobb

\section{ABSTRACT}

Fort Rucker Aviation Center in southeast Alabama is dependent on ground water for its water supply. The original well field at Fort Rucker, constructed in 1941-42, consisted of six multi-aquifer wells spaced about 2,000 feet apart. Uppermost screens in all of the wells are in the basal part of the Tuscahoma Sand about 150 to 200 feet below land surface. Forty years of pumpage from the wells resulted in declines in water levels. By 1976, some pumps were breaking suction and the demand for water was greater than the well field could supply. The study area consists of Dale County and parts of Coffee, Geneva, Henry, and Houston Counties.

The Tertiary-Cretaceous aquifer system in the study area consists of the basal part of the Tuscahoma Sand, the Nanafalia Formation, and the Clayton Formation of Tertiary age, and the Providence Sand and Ripley Formation of Cretaceous age. For this report the system is divided into an upper and lower aquifer. The upper aquifer consists of the Tuscahoma Sand, the Nanafalia and Clayton Formations, and the upper part of the Providence Sand. The lower aquifer consists of the lower part of the Providence Sand and the Ripley Formation.

Water levels were measured in selected wells in June and July 1982 to prepare a potentiometric map of the upper aquifer. An aquifer test made at Fort Rucker during the study indicates that the upper aquifer has transmissivity of about $7,800 \mathrm{ft}^{2} /$ day (feet squared per day) and a storage coefficient of $3 \times 10^{-4}$. The aquifer test and a potentiometric map of the principal aquifer system indicate that the original wells at Fort Rucker are spaced too closely. New wells installed at Fort Rucker in 1981 and 1982 resulted in reduced pumpage from the old wells. The combination of reduced pumpage from the old wells and wider spacing between the new wells resulted in a temporary recovery of water levels in the area.

Field water-quality data were collected for most wells in the study area. Field determinations for $\mathrm{pH}$, specific conductance, and temperature indicate that ground water is chemically suitable for most uses.

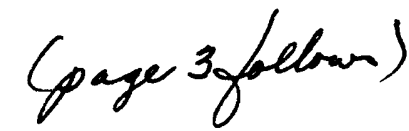




\section{INTRODUCTION}

Fort Rucker Aviation Center is in the southern part of Dale County in southeast Alabama. The study comprises an area of about 1,660 square miles that includes all of Dale County and parts of Coffee, Geneva, Henry, and Houston Counties (see fig. 1). Principal cities in the study area are Dothan, Ozark, and Enterprise. The Fort Rucker military reservation comprises an area of about 90 square miles within the study area.

The original Fort Rucker well field was installed in 1941-42. Six wells were drilled about 2,000 feet apart in a cluster. The wells are multiaquifer, and screens were installed in all of the wells in the basal part of the Tuscahoma Sand 150 to 200 feet below land surface. As a consequence of development of the shallow aquifer and the cone of depression that resulted from 40 years of pumpage, the pumps began breaking suction in the 1960's and serious water shortages began to occur by the summer of 1976 . Attempts were made to reconstruct the wells by removing the shallow well screens, but the reconstruction was essentially unsuccessful. In 1981, facilities engineers at Fort Rucker Aviation Center requested the U.S. Geological Survey to make a hydrologic and geologic study that would assist them in locating and designing a new well field to alleviate immediate and future water-supply problems at the center.

\section{Purpose and Scope}

The puxpose of this study is to evaluate the hydrogeology of the Tertiary-Cretaceous aquifer system in the Fort Rucker area. The study was designed to identify hydrologic problems in the area that would aid facilities engineers in locating and designing a new well field for Fort Rucker.

Field work included inventory of all military, public water-supply, industrial, and irrigation wells in the study area and selected domestic wells where additional information was needed (see fig. 2). Water levels were measured where possible, and field determinations for $\mathrm{pH}$, specific conductance, and water temperature were made at most sites. Water levels were measured in selected wells in the study area in June and July 1982. These data were used to prepare a potentiometric map of the upper aquifer. Drill cuttings, driller's logs, and geophysical logs were collected from four test wells at Fort Rucker and from other wells and test wells drilled in the area during the study. Drill cuttings were described by either the Geological Survey of Alabama or the U.S. Geological Survey. An aquifer test was conducted at Fort Rucker in March 1983 to estimate the hydraulic characteristics of the aquifer, and the magnitude of mutual interference of water levels between wells. 


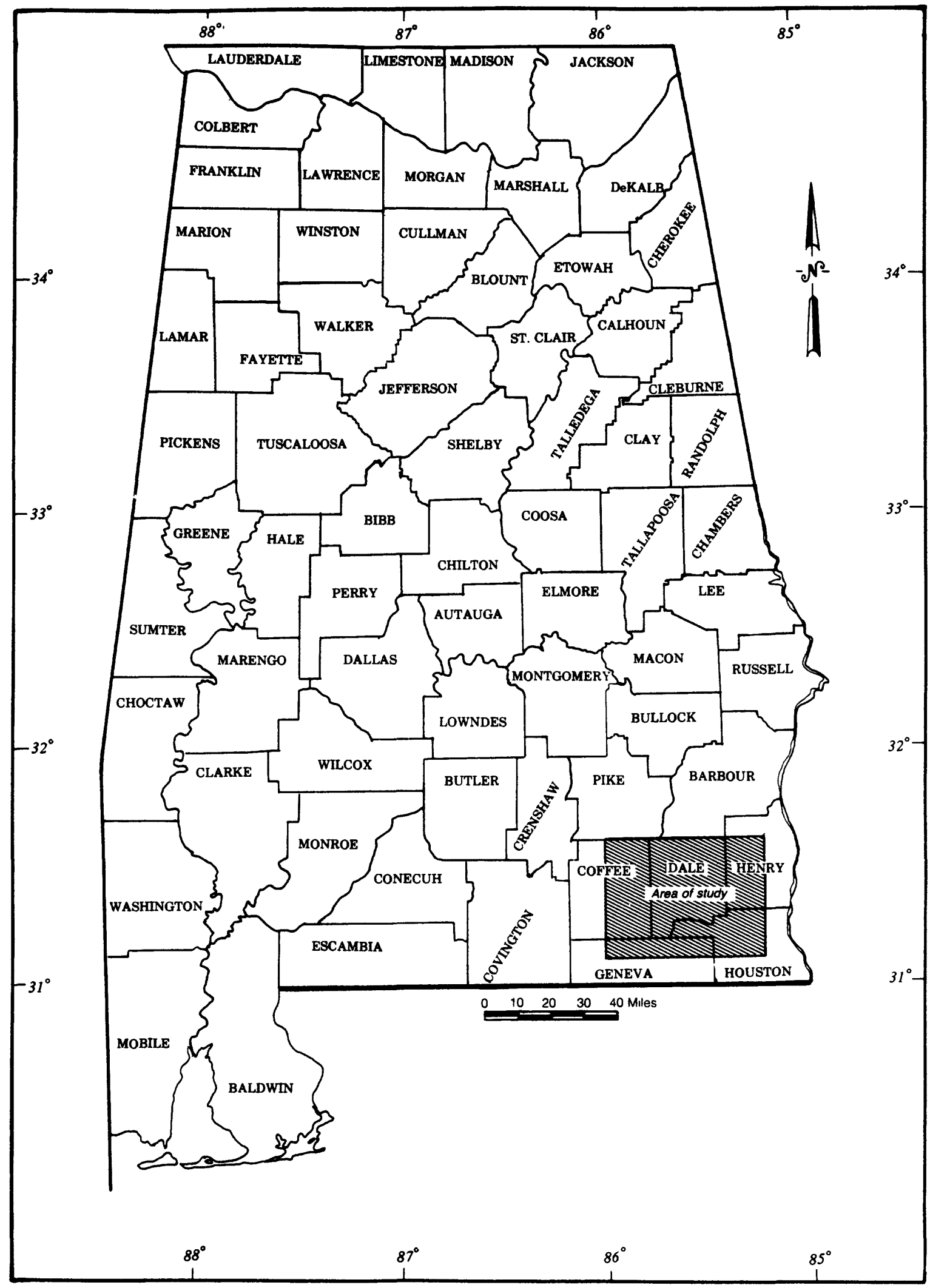

Figure 1.--Location of the area of study.

4 


\section{Previous Geologic and. Hydrologic Studies}

The first published geologic map that included the study area was probably Michael Toumey's geologic map of Alabama. The map was included in his second Biennial Report of the Alabama State Geologist in 1858. More detailed geologic maps of the state were prepared later by Smith and others (1894) and Adams and others (1926). A map of the Tertiary formations in Alabama was prepared by MacNeil (1946). Geologic maps of Coffee, Dale, Geneva, Henry, and Houston Counties were compiled in the 1960's by the U.S. Geological Survey in cooperation with the Geological Survey of Alabama. The geologic map in this report (fig. 3) is modified from the map by MacNeil (1946). MacNeil's map is not as detailed as the county geologic maps, but the detail presented is adequate for this report.

Ground-water data for the study area were published as early as 1907 in Eugene Allen Smith's "Underground Water Resources of Alabama" (Smith, 1907). More recent data are included in LaMoreaux (1948) and carter and others (1949). Water-availability studies were made in the 1960's by the U.S. Geological Survey in cooperation with the Geological Survey of Alabama. Results of these studies were published in county water-availability reports by the Geological Survey of Alabama.

\section{ACKNOWLEDGMENTS}

The authors thank Facilities Engineering personnel at Fort Rucker, and waterworks officials at Dothan, Ozark, Enterprise, and several other cities and towns in the study area. Particular acknowledgment is due Col. Dan Barney, Director of Facilities Engineering at Fort Rucker, Mr. Joseph Hayes, Mr. Robert Flemming, and Mr. John Ard of Fort Rucker for their assistance in the collection of hydrologic data. Acknowledgment is also made to

Layne-Central Company, Pensacola, Florida and Donald Smith of Smith Well and Supply Company, Headland, Alabama for furnishing data for wells in the study area. 


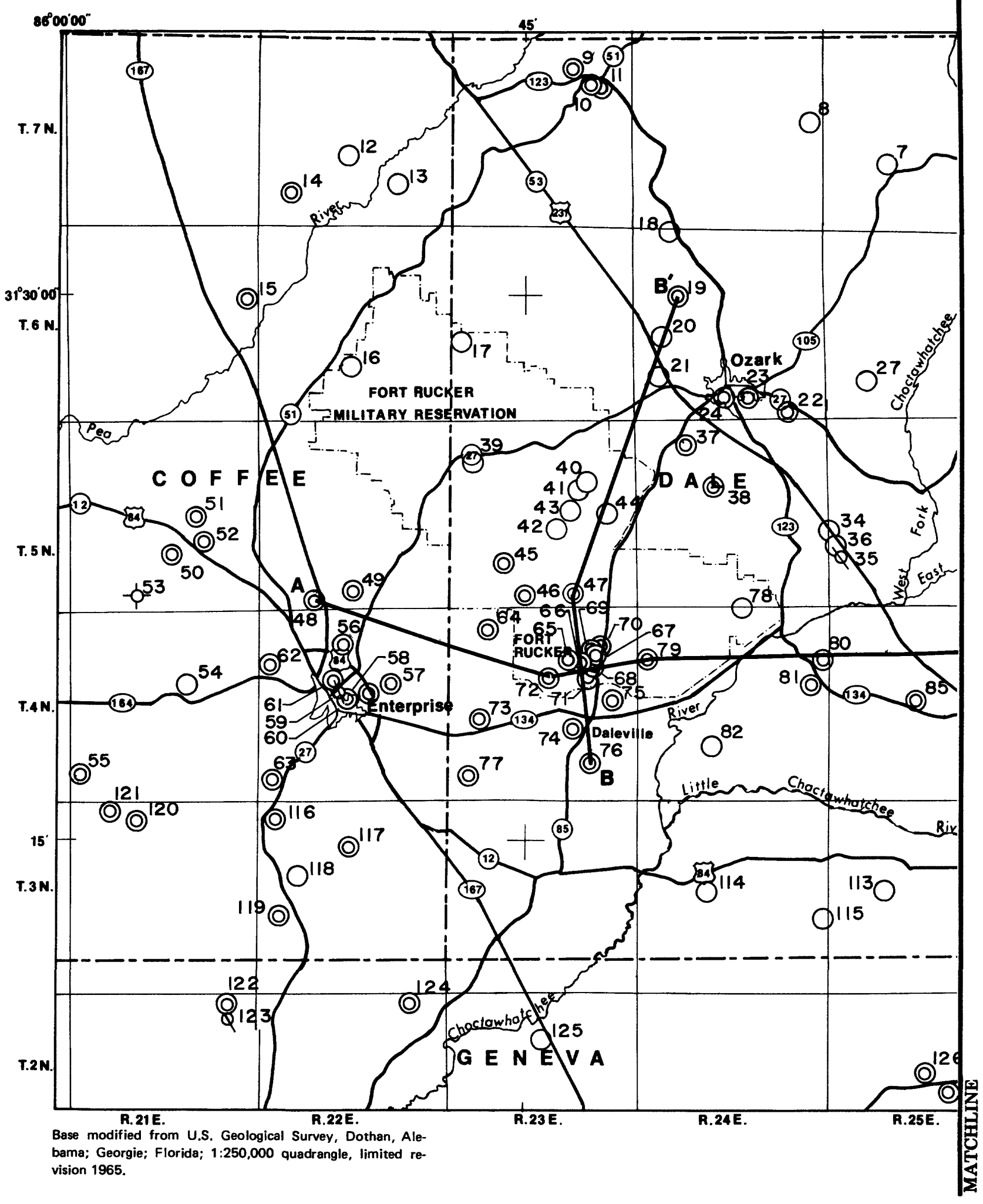

Figure 2.--Locations of wells and stratigraphic cross sections. 


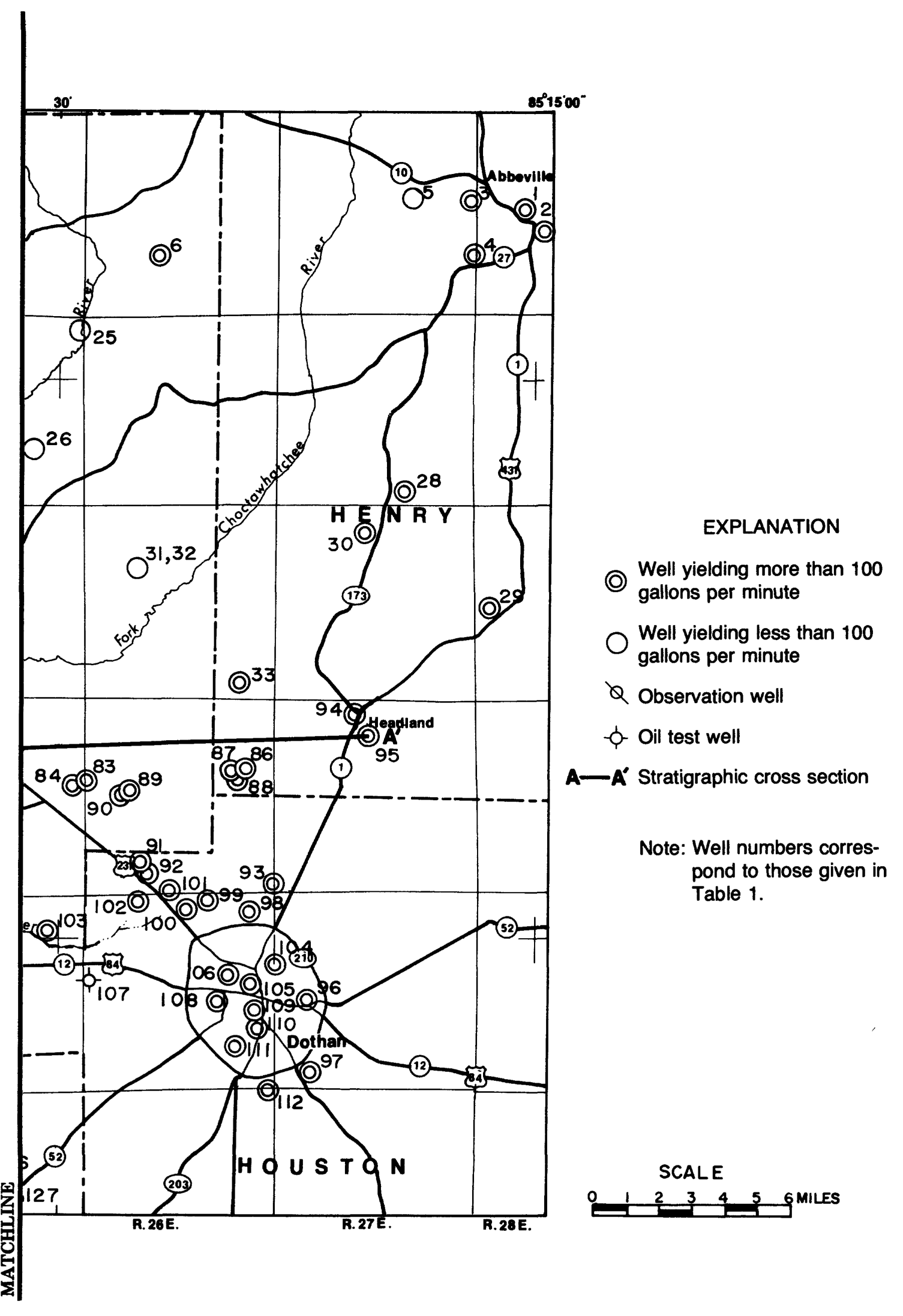




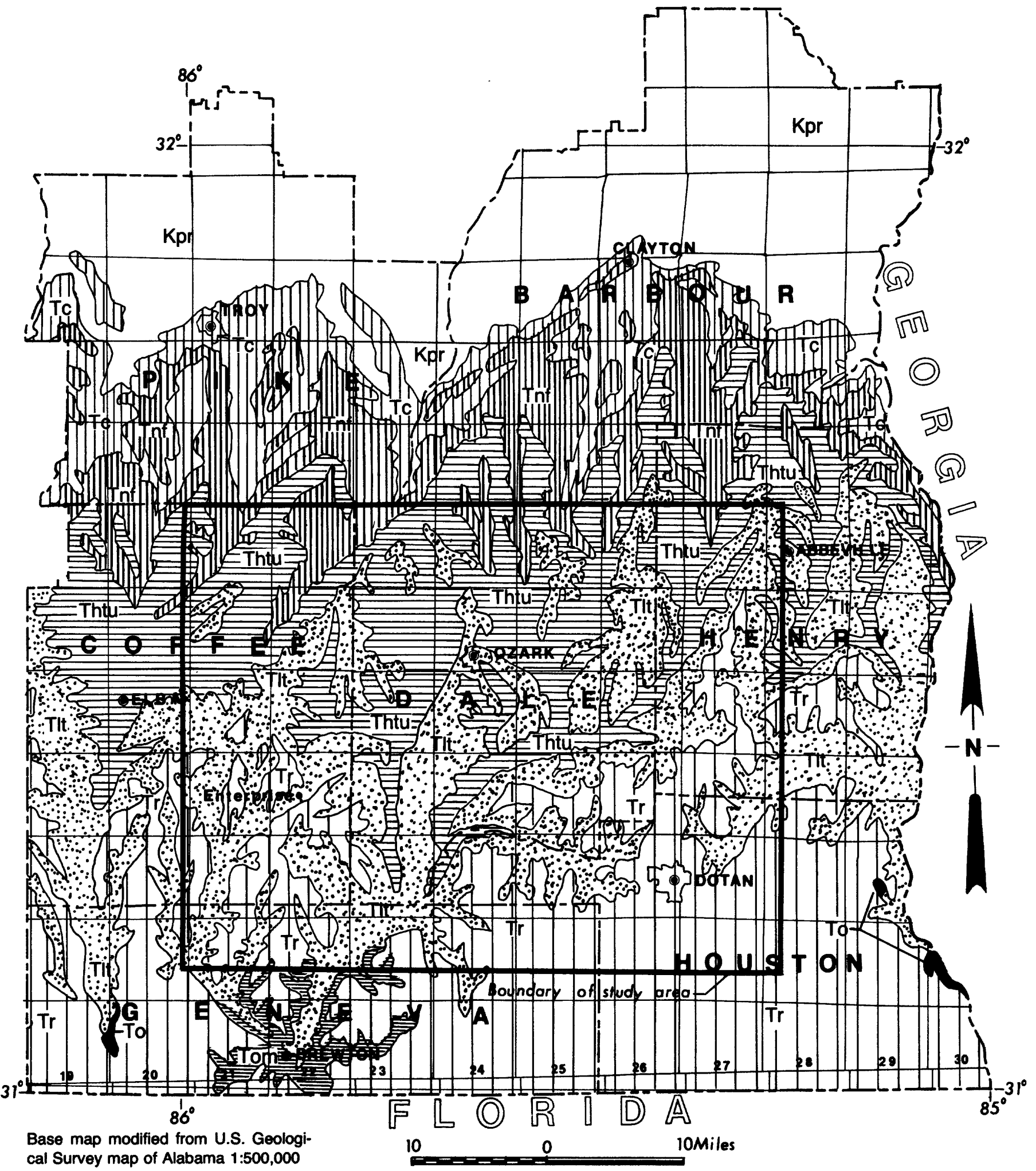

Figure 3.--Generalized geologic map of the Cretaceous and Tertiary formations in southeastern Alabama. 


\section{EXPLANATION}

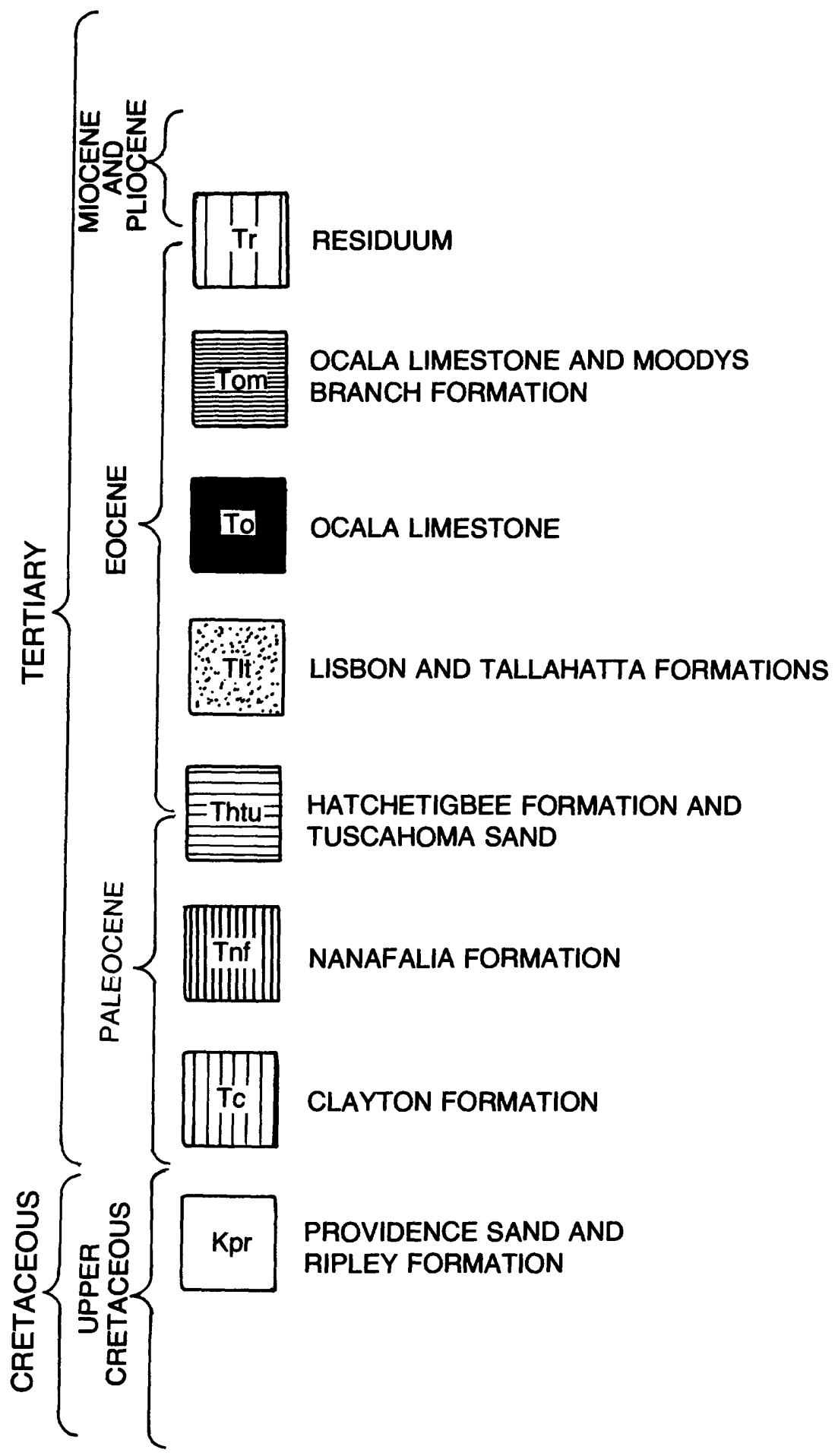


The study area is in the Southern Red Hills and Dougherty Plain districts of the East Gulf Coastal Physiographic section (Sapp and Emplaincourt, 1975). The Southern Red Hills are characterized by sand hills dissected by southwardflowing streams. The Dougherty Plain is a relatively flat upland that slopes gently southward except where dissected by streams.

Most of the study area is drained by the Choctawhatchee River and its tributaries. The northwestern corner of the area is drained by the Pea River and its tributaries, and the eastern edge of the area is draj iten by tributaries to the Chattahoochee and Chipola Rivers.

The average annual rainfall in the study area is about 54 inches. The wettest months usually are March and July; the driest usually are October and November.

\section{GEOLOGIC FORMATIONS AND THEIR WATER-BEARING CHARACTERISTICS}

The study area is underlain by sedimentary deposits of Cretaceous and Tertiary age (fig. 3). These deposits strike generally eastward and dip southward 15 to 25 feet per mile. Geologic formations that comprise the Tertiary-Cretaceous aquifer system are from oldest to youngest, the Ripley Formation and Providence Sand of Cretaceous age and the Clayton and Nanafalia Formations and Tuscahoma Sand of Tertiary age (figs. 4 and 5). The Hatchetigbee, Tallahatta, and Lisbon Formations overlie the Tuscahoma Sand, but are not important aquifers in the study area.

\section{Ripley Formation}

The Ripley Formation is the deepest geologic unit tapped for water supplies in the Fort Rucker area. The Ripley crops out north of the study area in Barbour and Bullock Counties and in the northern part of Pike County. The formation is about 350 to 400 feet thick immediately south of the outcrop and may be more than 500 feet thick in the study area. The Ripley consists of sand and calcareous clay interbedded with calcareous sandstone and sandy limestone. The upper 150 feet of the unit consists mainly of sand and sandy limestone; the lower part consists mainly of calcareous clay and calcareous sandstone. In the outcrop area, the Ripley is subdivided into the Cusseta Sand Member and an upper unnamed member. Analysis of drill cuttings and geophysical logs of test wells at Fort Rucker indicates that subdivision of the formation in the study area is impractical. Sample logs of drill cuttings collected from several wells in the study area are given in table 2. Driller's logs of selected wells are given in table 3. These logs give detailed lithologic descriptions of the Ripley and overlying geologic formations. 


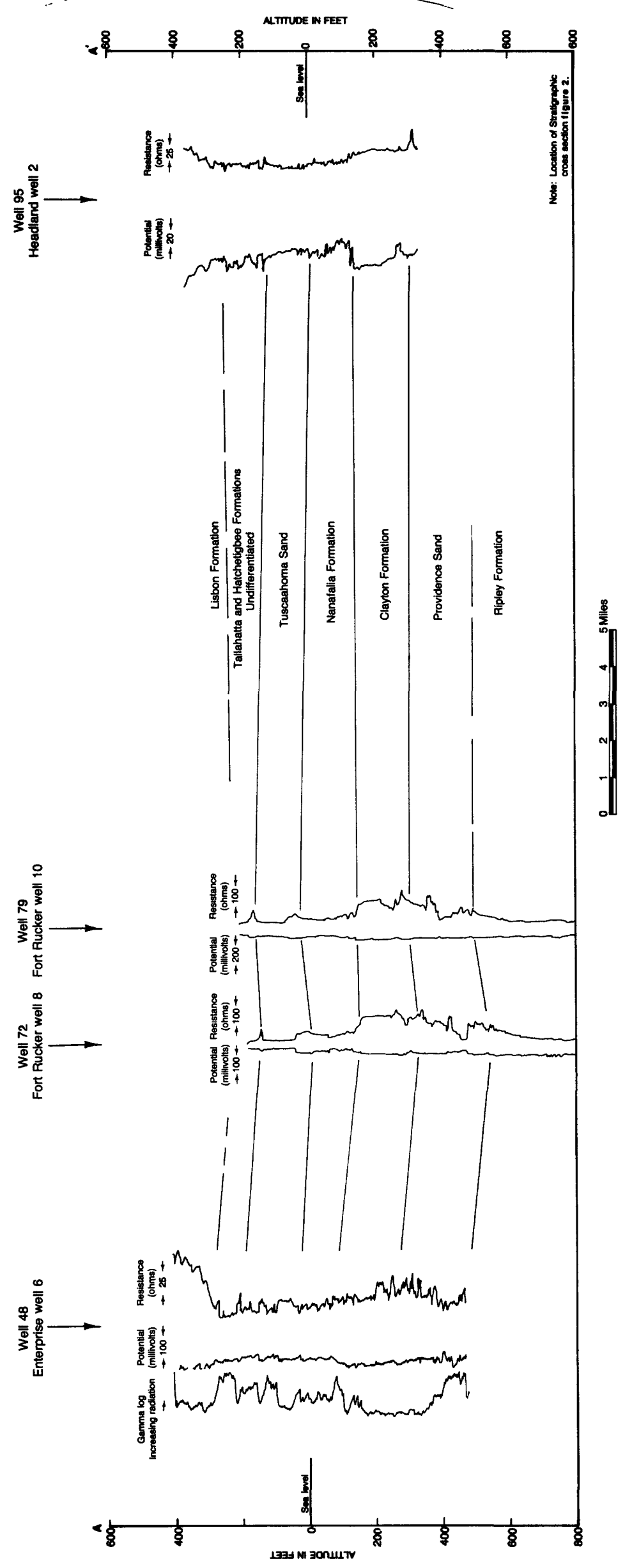

OD 


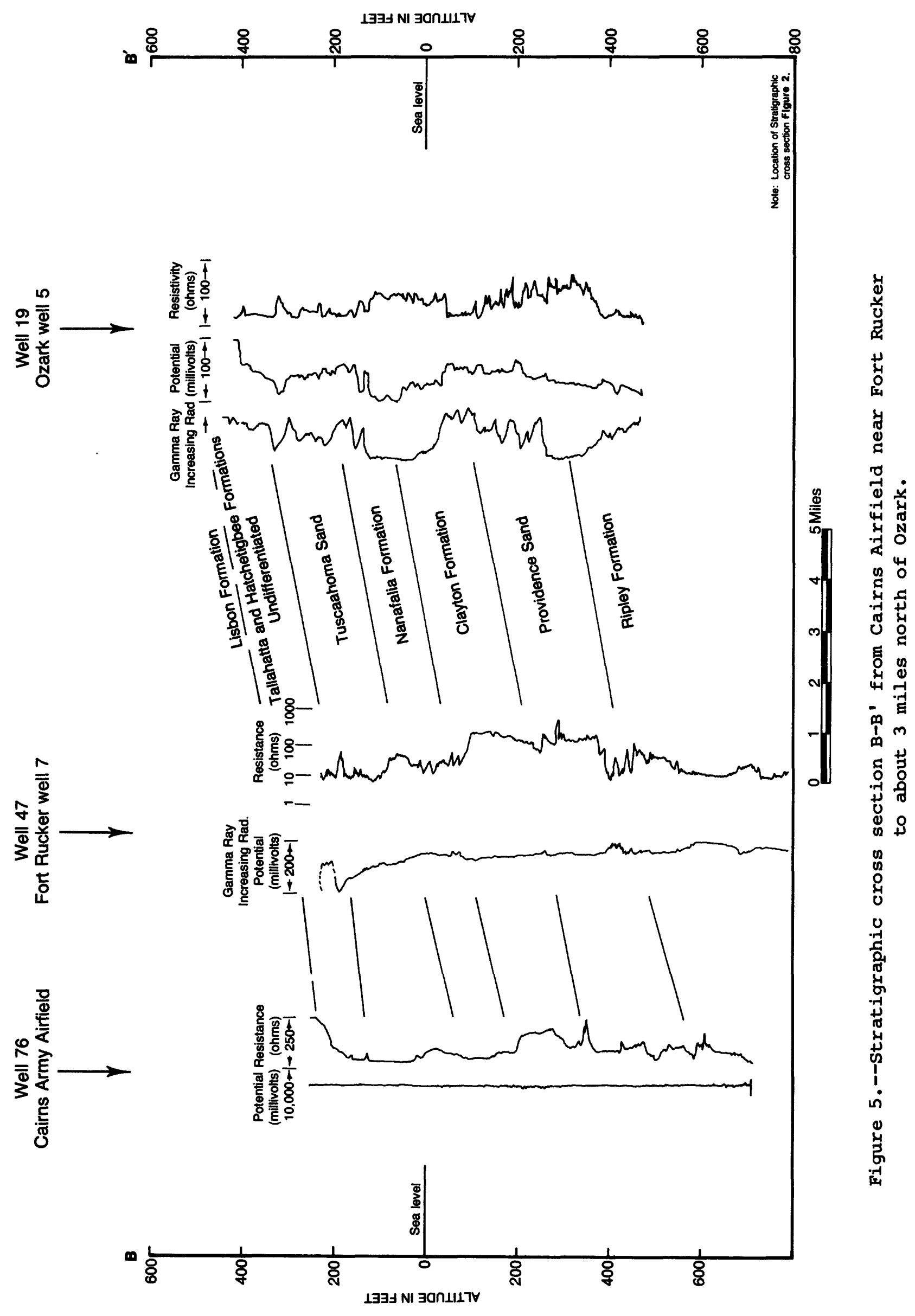


The upper part of the Ripley formation is developed for water supplies at Fort Rucker and the cities of Ozark and Dothan. The Ripley Formation is usually developed in conjunction with the overlying Providence Sand. However, municipal wells at Ozark are apparently screened solely in the Ripley. Ozark well 4 (well 22) had a drawdown of 89 feet after pumping $750 \mathrm{gal} / \mathrm{min}$ (gallons per minute) for 24 hours in 1968.

\section{Providence Sand}

The Providence Sand, the uppermost Cretaceous formation, overlies the Ripley Formation and crops out in Barbour, Bullock, and Pike Counties. The Providence, in the area of outcrop, consists of the Perote Member at the bottom and an unnamed member at the top. The Perote Member consists mainly of clay, and the unnamed upper member consists mainly of sand. These lithologies are present in the subsurface in the Fort Rucker area. Sand in the upper member, however, is interbedded with sandy limestone and calcareous sandstone, and the lower part of the Perote Member is mainly sand. The Providence is about 150 to 220 feet thick in the outcrop area and in the subsurface in the Fort Rucker area.

The Providence is a major source of water supply at Fort Rucker, Enterprise, Dothan, and at several smaller towns and communities in the study area. The Providence is generally developed in conjunction with the underlying Ripley Formation or with the overlying Clayton and Nanfalia Formations and the Tuscahoma Sand. A municipal well at Dothan (well 91), apparently screened solely in the Providence, had a drawdown of 36 feet after pumping $876 \mathrm{gal} / \mathrm{min}$ for 48 hours in 1974 .

\section{Clayton Formation}

The Clayton Formation, the lowermost Tertiary formation in the study area, overlies the Providence Sand and crops out in southern Bullock County and in Barbour and Pike Counties. At outcrops, the clayton consists of a basal sand that is overlain by relatively pure limestone. This limestone is overlain by sandy limestone and sandy clay that comprise the upper part of the formation. The maximum thickness of the clayton in Barbour County is about 125 feet (Newton, 1965) and in Pike County is about 180 feet (Shamberger, 1968). Analysis of drill cuttings from test wells at Fort Rucker indicates that the thickness of the clayton in the study area is about 150 to 175 feet. The lithologic character of the formation in the subsurface is similar to that at outcrops except that most outcrops are deeply weathered and much of the limestone is absent due to solution.

The Clayton is a major aquifer in some parts of southeast Alabama, and is developed in some of the original wells at Fort Rucker. However, tests made in the clayton during the 1981-82 test drilling program at Fort Rucker indicate that the limestone in the clayton is not very permeable in the vicinity of Fort Rucker. The low permeability probably results from the limited extent of solution channel development compared to the more extensive channeldevelopment in the clayton in other parts of the study area. A capacity test for a well developed in the Clayton at Battens Crossroads indicates that the well had a drawdown of 15 feet after pumping 112 gal/min for 24 hours in 1968 . 


\section{Nanafalia Formation}

The Nanafalia Formation overlies the Clayton Formation in the study area, and crops out in southern Barbour and Pike Counties, and in northern Coffee, Dale, and Henry Counties. The Nanafalia consists of siltstone, calcareous clay, and sand in the area of its outcrop. In the subsurface in the Fort Rucker area, the unit consists of glauconitic fossiliferous sand, calcareous carbonaceous clay, and sandy limestone. The Nanafalia is about 100 to 160 feet thick in the study area.

Sand beds in the Nanafalia Formation are a major source of water in the study area. The Nanafalia is usually developed in conjunction with the overlying Tuscahoma Sand and the underlying Clayton Formation and Providence Sand. The original wells at Fort Rucker are screened in the Nanafalia, but are also screened in the Tuscahoma, Clayton, and Providence. A capacity test made for a well at Newville, apparently screened solely in the Nanafalia, indicates that the well had a drawdown of 86 feet after pumping $210 \mathrm{gal} / \mathrm{min}$ for 24 hours in 1974 .

\section{Tuscahoma Sand}

The Tuscahoma Sand overlies the Nanafalia Formation and crops out over a large part of the study area (fig. 3). The basal part of the Tuscahoma consists primarily of glauconitic sand which is 25 to 50 feet thick in the Fort Rucker area. The upper part consists of 80 to 120 feet of calcareous carbonaceous clay. Geohydrologic data indicate that both parts of the Tuscahoma thicken toward the west.

The Tuscahoma is developed for water supplies in conjunction with underlying formations at Fort Rucker, Enterprise, Dothan, and several other towns and communities in the study area. Large capacity wells (wells producing 100 gal/min or more) are rarely developed exclusively in the Tuscahoma. Records of a few wells that are developed exclusively in the Tuscahoma indicate that wells in the Tuscahoma area generally have specific capacities ranging from 1 to 2 (gal/min)/ft (gallons per minute per foot of drawdown).

\section{Hatchetigbee Formation}

The Hatchetigbee Formation overlies the Tuscahoma Sand and crops out in Coffee, Dale, and Henry Counties. The Hatchetigbee is included with the underlying Tuscahoma Sand on MacNeil's geologic map (fig. 3). The Hatchettigbee consists of a basal glauconitic sand bed that is 4 to 10 feet thick at outcrops, and upper beds that consist mainly of carbonaceous clay. The upper part of the unit generally ranges in thickness from 20 feet in Henry county to 50 feet in Coffee County. Test well records indicate that the Hatchetigbee is about 50 feet thick at Fort Rucker.

The Hatchetigbee is not a major aquifer in the study area, and is generally not tapped by large capacity wells. Some domestic wells in the study area are developed in the basal sand bed of the Hatchetigbee. 


\section{Tallahatta Formation}

The Tallahatta Formation overlies the Hatchetigbee Formation and crops out in Coffee, Dale, and Henry Counties. The Tallahatta varies in thickness and lithology throughout the study area. The unit is only about 20 feet thick in northern Coffee County, but is more than 100 feet thick in the southern part of the study area. The Tallahatta consists of silty clay, calcareous sandstone, and fossiliferous silty sand. At some outcrops in Dale and Henry Counties, the Tallahatta contains beds of massive siltstone which are typical of the formation in southwest Alabama. The Tallahatta is included with the overlying Lisbon Formation on MacNeil's geologic map.

The Tallahatta Formation is not a major aquifer in the study area, although it was a principal source of water for Dothan in the early years of Dothan's public water system. Dothan presently (1983) uses one well (well 109) developed in the Tallahatta and the overlying Lisbon Formation. A capacity test made for this well in 1955 indicated a drawdown of 53 feet after pumping $584 \mathrm{gal} / \mathrm{min}$ for 8 hours. The Tallahatta is a principal source of water for several towns and communities south of the study area.

\section{Lisbon Formation}

The Lisbon Formation overlies the Tallahatta Formation and crops out on uplands over much of the study area. The Lisbon generally ranges in thickness from 20 feet in northern Henry County to 150 feet along the southern part of the study area. The Lisbon consists of sand, sandy limestone, and calcareous sandy clay in the subsurface. At outcrops, the Lisbon is generally weathered to massive silty sand.

The Lisbon Formation is not a major aquifer in the study area, mainly because of its proximity to the land surface. The Lisbon is a principal source of water supply south of the study area, especially in southern Houston County where it is developed in conjunction with the overlying Ocala Limestone for irrigation and public water supplies. The Lisbon is developed in some parts of the study area for domestic and stock supplies.

\section{$\underline{\text { Residuum }}$}

The uppermost Tertiary formations in the study area consist of residual clay, sand, gravel, and chert boulders that are the residual remains of the Moodys Branch Formation and the Ocala Limestone of Eocene age and Miocene and (or) Pliocene deposits. These deposits, which have been jumbled due to the solution of the limestone, are collectively named residuum. The residuum is generally less than 25 feet thick at Fort Rucker, but may be as much as 100 feet thick in the Dothan area.

Because of the jumbled heterogeneous characteristics of the residuum, it is not a significant source of water in the study area. Domestic and stock wells in some parts of the area are developed in the residuum. In southern parts of Houston and Geneva Counties, where the Ocala Limestone has not been 
completely dissolved, it is a major aquifer for municipal, irrigation, and other farm-related uses. Some wells in this area are developed solely in the Ocala; others are developed in the Ocala and the underlying Lisbon Formation. The Ocala Limestone and the Moodys Branch Formation undifferentiated crop out along the southern margin of the study area.

\section{Terrace and Alluvial Deposits}

Terrace and alluvial deposits of Quaternary age are present along and adjacent to the flood plains of major streams in the study area. These deposits consist of sand, silt, clay, and small gravel, and are usually not more than 25 feet thick. These deposits, which are not shown on MacNeil's geologic map, are most extensive in the valleys of the Choctawhatchee and Pea Rivers.

The terrace and alluvial deposits are not a major source of water in the study area. A few domestic wells are developed in the deposits.

\section{HYDROLOGY OF THE TERTIARY-CRETACEOUS AQUIFER SYSTEM}

The Tertiary-Cretaceous aquifer system in the study area consists of water-bearing units in several geologic formations. Geologic formations comprising the aquifer system are the basal part of the Tuscahoma Sand and the Nanafalia and Clayton Formations of Tertiary age, and the Providence and Ripley Formation of Cretaceous age (see fig. 6). A clay zone in the upper part of the Tuscahoma Sand is the upper confining layer for the aquifer system and massive clay beds in the lower part of the Ripley Formation comprise the lower confining layer. Geologic and hydrologic data compiled during the study indicate that a clay zone in the Providence Sand is a third confining layer that divides (to some extent) the aquifer system into an upper and lower aquifer. Therefore, for this stsudy, the Tertiary-Cretaceous aquifer system is divided into an upper aquifer consisting of the Tuscahoma sand, the Nanafalia and Clayton Formations, and the upper part of the Providence Sand, and a lower aquifer consisting of the lower part of the Providence Sand and the upper part of the Ripley Formation. Fort Rucker, Dothan, and Enterprise pump water mainly from the upper aquifer; Ozark pumps water from the lower aquifer.

\section{Source of Ground Water}

All ground water in the study area is derived from rainfall that occurs on or north of the area. Most of the rainfall leaves the area as runoff through streams or as evapotranspiration. Some of the rainfall infiltrates downward to recharge the aquifers that underlie the study area. 


\section{Recharge and Discharge}

The amount of recharge received by the aquifers is difficult to estimate because it is dependent on when the rainfall occurs, the intensity and magnitude of the rainfall, and atmospheric and hydrologic conditions such as air temperature and soil-moisture conditions. For example, a 2-inch rainstorm in July will usually run off or remain in the soil zone, later to be evaporated or transpired back to the atmosphere. A 2-inch rain in December will usually result in significant recharge because the evapotranspiration rate is low and because winter rains generally are less intense and of longer duration than summer rainstorms.

The area of recharge for the Tertiary-Cretaceous aquifer system is 20 to 50 miles updip (north) of pumping centers in the study area (see fig. 6). The recharge area for the upper aquifer is 20 to 40 miles updip from the pumping centers; the recharge area for the lower aquifer is 40 to 50 miles updip.

Water moves downdip through the aquifer system to points of downdipdischarge. The principal areas of downdip-discharge are at major pumping centers in the study area. Major centers that pump from the upper aquifer are Fort Rucker, Dothan, and Enterprise. Ozark is the major center that pumps from the lower aquifer.

A large part of the recharge in the outcrop area is lost as discharge to perennial (ground-water supported) streams. A major control on the amount of recharge received by the aquifer is the transmissivity of the aquifer downdip. The downdip-transmissivity limits the amount of water that can move through the aquifer from the area of outcrop. A transmissivity of $7,800 \mathrm{ft}^{2} / \mathrm{d}$ and a hydraulic gradient of $10 \mathrm{ft} / \mathrm{mi}$ will permit about $0.6 \mathrm{Mgal} / \mathrm{d}$ per lineal mile of outcrop area to move through the upper aquifer. Expressed another way, this is about 1.4 inches of recharge per square mile of outcrop.

\section{Aquifer Test}

An aquifer test was conducted at Fort Rucker during the week of March 14-18, 1983. The purposes of the test were to obtain data from which estimates of hydraulic characteristics (transmissivity and storage) of the upper aquifer could be made and to determine the magnitude of pumping-level interference between wells. Well 70 (Fort Rucker well 9) was used as the pumping well during the 24-hour test, and drawdown measurements were made in wells 65, $66,69,71$, and 79 (Fort Rucker wells 1, 2, 4, 6, and 10) which were not pumping during the test period (figs. 7 and 8 ). Wells 47 and 72 (Fort Rucker wells 7 and 8 ) were pumping at a constant rate into the Fort Rucker water system prior to and during the test period. Wells 67 and 68 (Fort Rucker wells 3 and 5) were not pumping, but were not used for the aquifer test.

Data obtained during the test indicate that the Tuscahoma Sand, the Nanafalia and Clayton Formations, and the upper part of the Providence Sand are hydraulically interconnected at Fort Rucker, and can be considered to be a single aquifer (upper aquifer) from a hydrologic viewpoint. Figure 9 is a semi-logrithmic plot of drawdown versus the radius (distance) from the pumping 


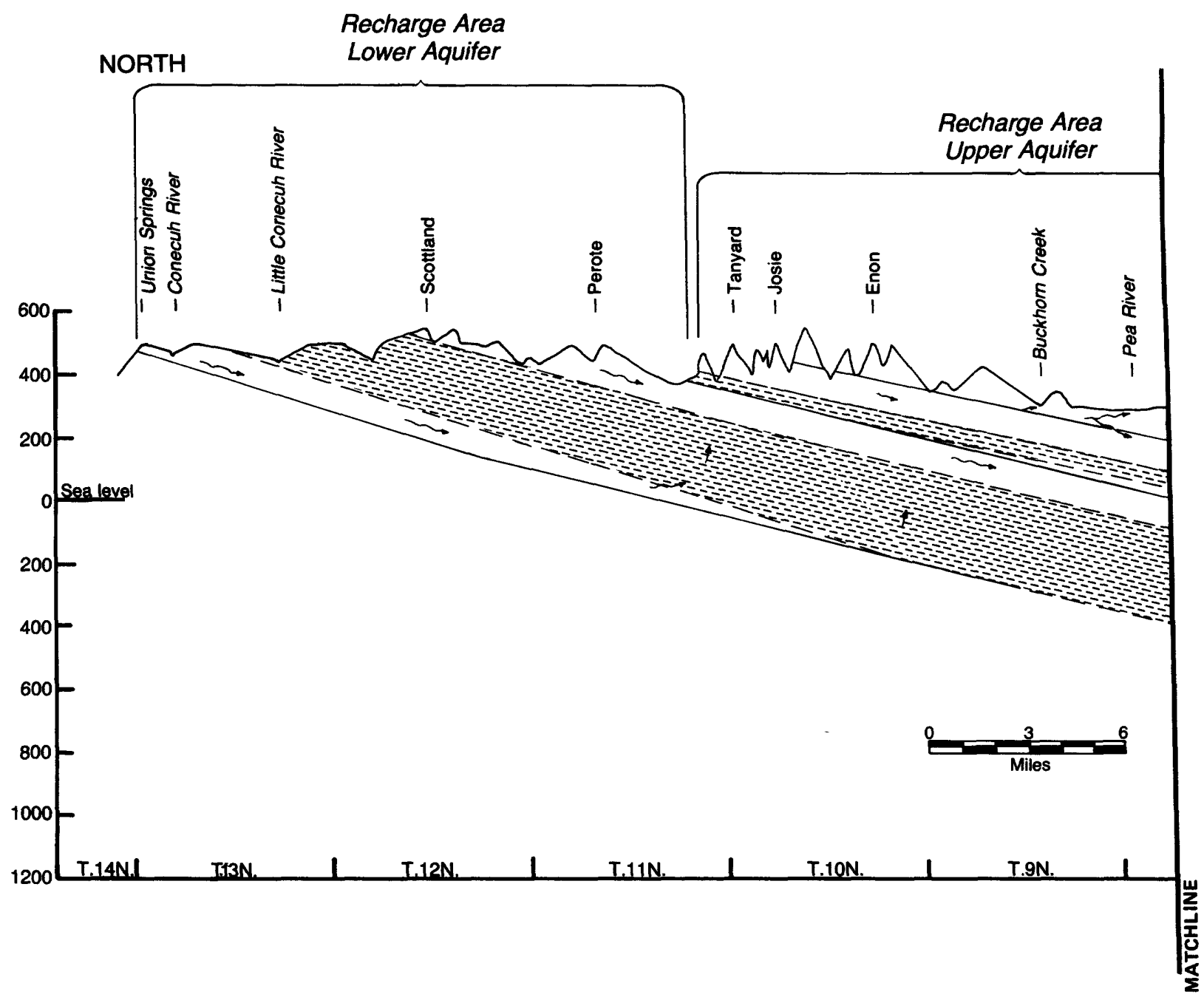

Figure 6.--Generalized cross section of the aquifer system. 


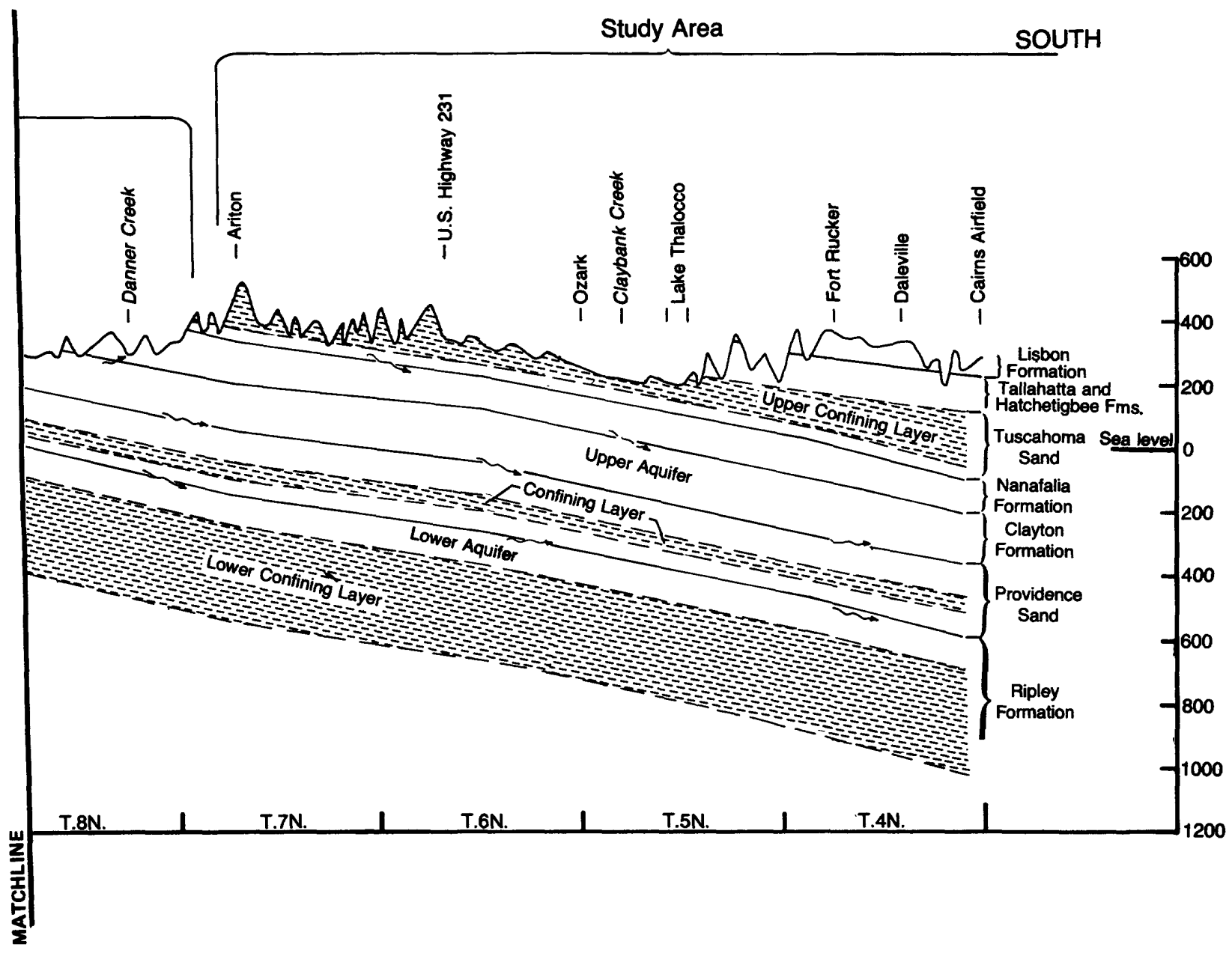




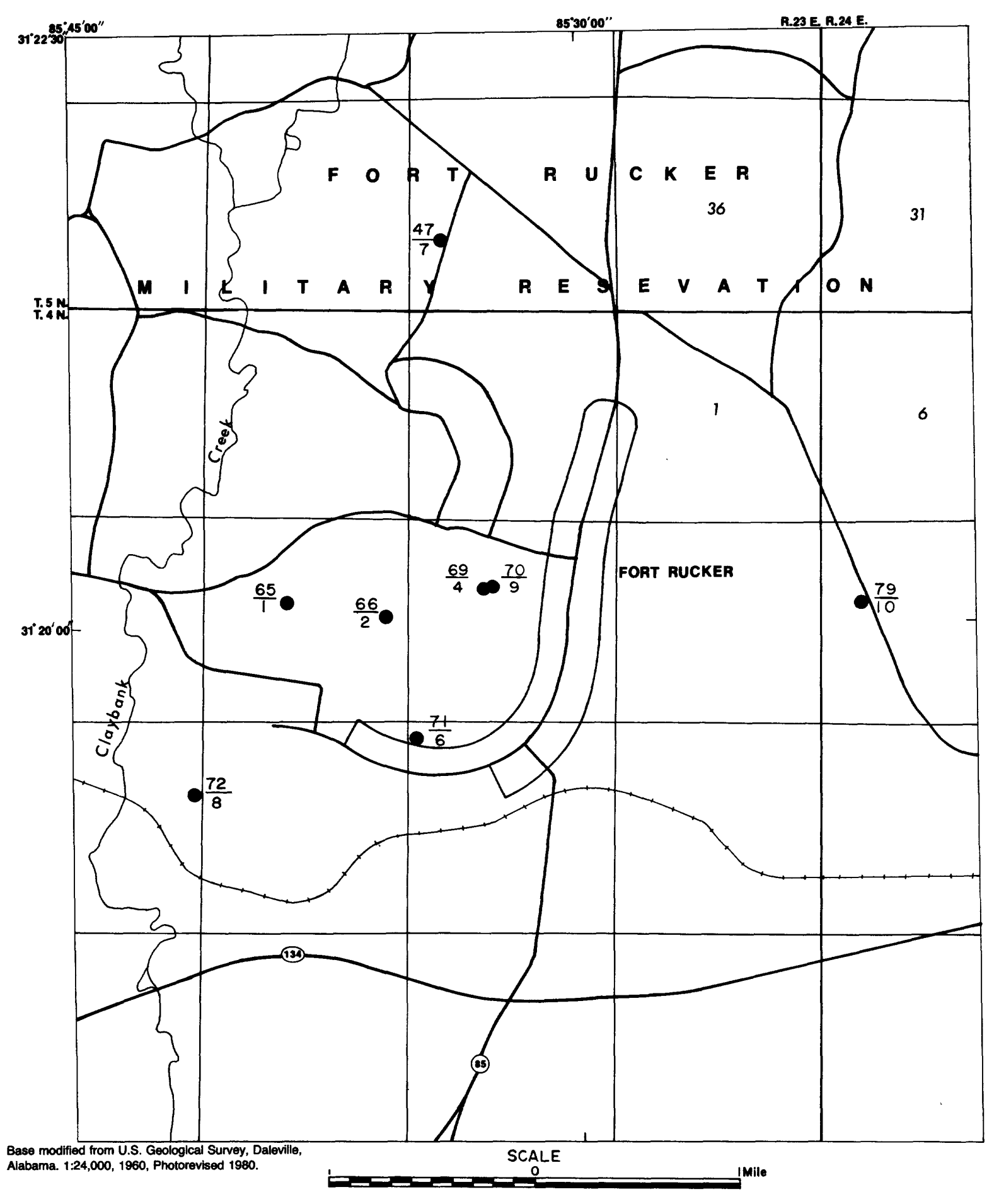

EXPLANATION

$\frac{72}{8}$ Number shown in Figure 2
Fort Rucker well number

Figure 7.--Locations of wells used in aquifer test at Fort Rucker. 


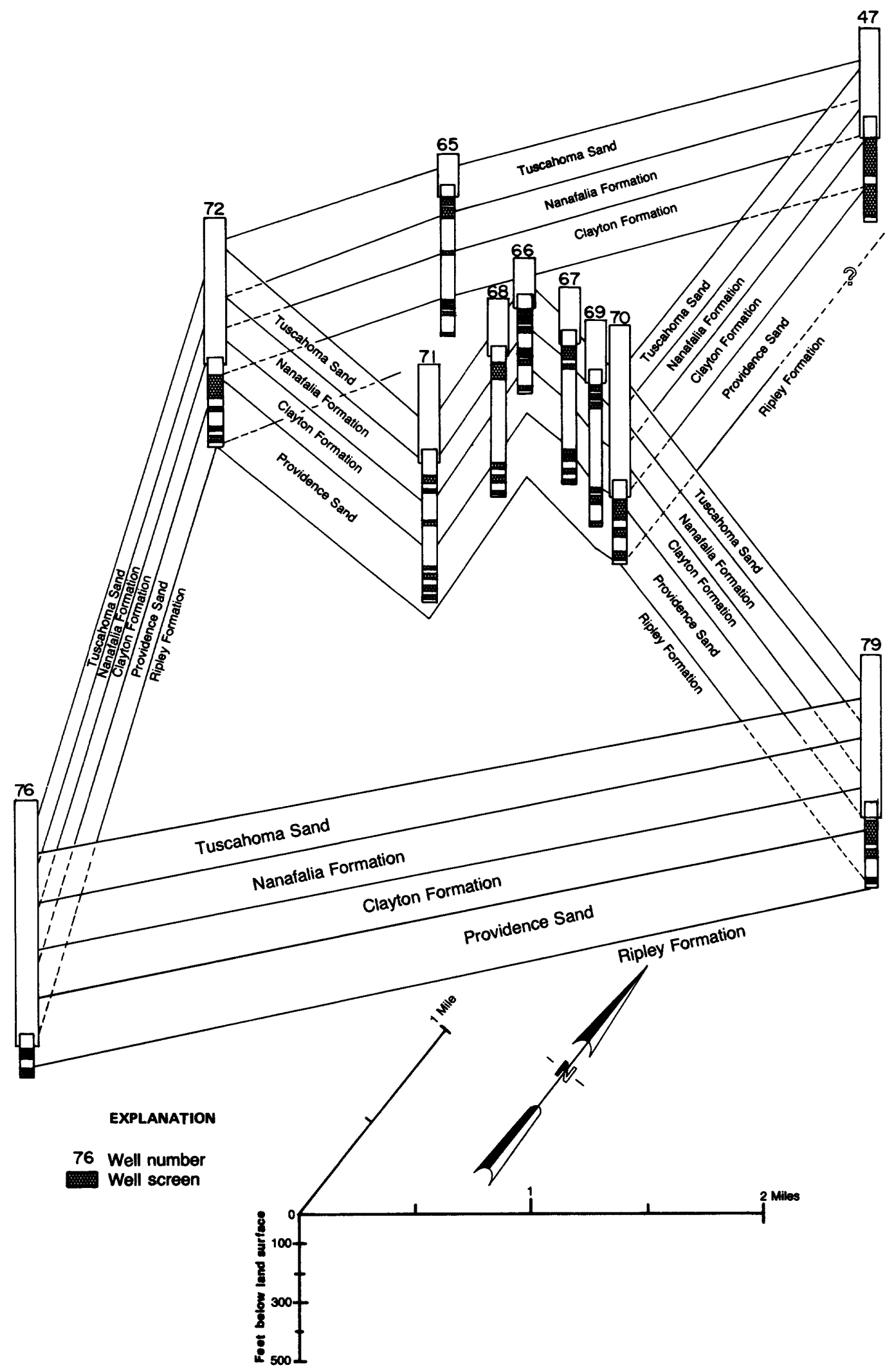

Figure 8.--Fence diagram of production wells at Fort Rucker in 1983. 


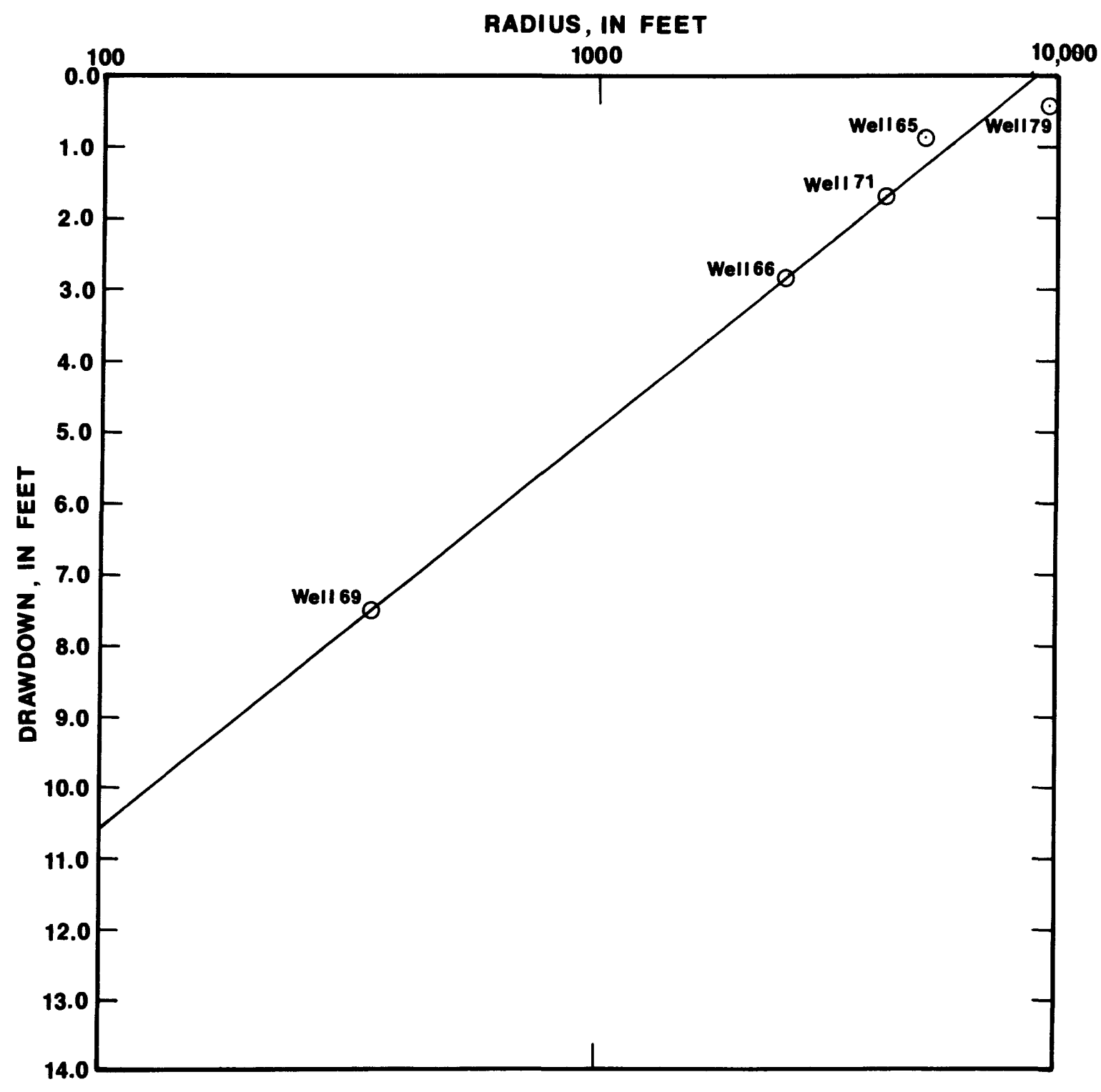

Figure 9.--Drawdown in wells at Fort Rucker during aquifer test. 
well after 24 hours of pumping. The transmissivity is determined by the slope of the line drawn through the points in the following equation:

$$
T=\frac{-2.30 Q}{2 / \log 10 x}
$$

where $T=$ transmissivity, in feet squared per day,

$Q=$ discharge of the well, in cubic feet per day,

$\mathbf{s}=$ drawdown, in feet,

and $r=$ radius, in feet from pumping well.

Computations of data collected during the test indicate that the upper aquifer has a transmissivity of about $7,800 \mathrm{ft}^{2} / \mathrm{d}$ and a coefficient of storage of about $3 \times 10^{-4}$. These values are in the normal range for an artesian aquifer consisting of unconsolidated sediments.

The drawdown data indicate that the interference of pumping levels between the new wells is relatively small, and that interference between well 70 (Fort Rucker well 9) and the old wells is sufficiently small to allow pumping from well 70 and one or more of the old wells without serious mutual interference. Figure 10 is a suite of curves that depicts, in a general way, the theoretical drawdown at various distances from a well that is discharging constantly from the upper aquifer at a rate of $700 \mathrm{gal} / \mathrm{min}$ (Knowles and others, 1963). The curves, which show drawdowns after 1, 5, 10, and 20 years of continuous pumping, may be used to aid in estimating optimum spacing of future wells at Fort Rucker. For example, a well discharging at a rate of 700 gal/min 5,000 feet from an idle well would cause a drawdown of 14.5 feet in the idle well after 20 years of continuous pumping. The curves may also be used to estimate the mutual interference between existing wells. The data plots for the curves were computed from the aquifer characteristics obtained from the aquifer test at Fort Rucker.

Capacity tests made by Fort Rucker personnel in 1975 indicate that the well field was capable of producing from 3.0 to $3.5 \mathrm{Mgal} / \mathrm{d}$ at that time (oral commun., Mr. John Ard, Fort Rucker Waterworks Manager, 1982). Well 47 was placed in production in 1977 and wells 70, 72, and 79 were placed in production in 1982-83. Pumpage from these wells combined with selected pumpage from the original wells will produce 5 to $6 \mathrm{Mgal} / \mathrm{d}$. An additional well, to be completed in 1984, will increase the capacity of the well field by about 0.8 Mgal/d.

\section{Withdrawals}

Pumpage from the aquifer system for public water supplies has increased by as much as a factor of 10 during the past 40 years. Reported daily water use at Dothan was about 1.4 million gallons in 1946 (Carter and others, 1949). Maximum daily use is presently (1983) about 14.8 million gallons. Pumpage at Ozark, which was about $0.25 \mathrm{Mgal} / \mathrm{d}$ in 1946, is presently $2.75 \mathrm{Mgal} / \mathrm{d}$. Pumpage at Enterprise has increased from $0.4 \mathrm{Mgal} / \mathrm{d}$ in 1946 to $5.3 \mathrm{Mgal} / \mathrm{d}$ in 1983 . Historical pumpage records for Fort Rucker are not available. However, water level records compiled for the original wells at Fort Rucker indicate an 


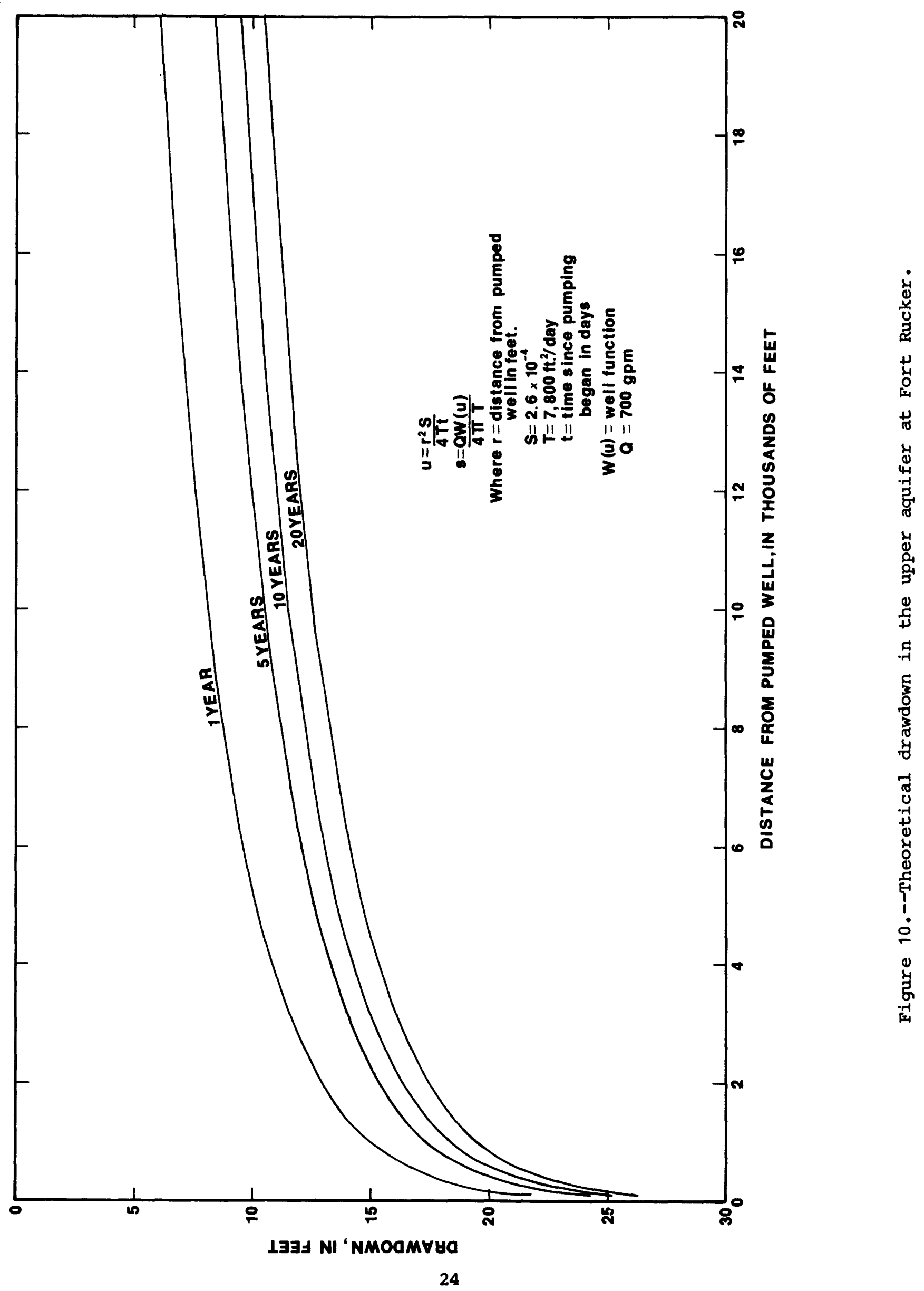


accelerated rate of decline from 1976 to 1982. Waterworks officials report that the demand exceeded the capacity of the wells during summer months from 1976 to 1982 (oral commun., Mr. John Ard, Fort Rucker Waterworks Manager, 1982).

Ground-water withdrawals for irrigation use increased significantly during the past 40 years. Pumping from ground-water sources for irrigation was practically nonexistent in the $1940^{\prime} \mathrm{s}$, but is presently common in some parts of the study area. The amount of water used for irrigation is difficult to estimate because irrigation is seasonal and sporadic due to climatic conditions and crop requirements. However, based on available data for irrigation wells in the study area, $10 \mathrm{Mgal} / \mathrm{d}$ or more of ground water is used for irrigation some of the time during the growing season. Use of ground water for irrigation will probably accelerate more in the next 40 years as farmers attempt to maximize production to compensate for increasing costs of fuel, fertilizer, and farm machinery.

The current total use of ground water for industry is estimated to be about $5 \mathrm{Mgal} / \mathrm{d}$. Industrial use of ground water has not increased as significantly as use for irrigation and public supplies, because the economy is based on agriculture. Industrial ground-water use will probably increase during the next 40 years and may increase significantly if industry continues to expand in the area as it has during the past 15 years.

\section{Fluctuations of the Potentiometric Surface}

In a confined artesian aquifer system such as the one underlying the study area, the level to which water will rise in wells developed in the aquifer is called the potentiometric surface. The potentiometric surface fluctuates in response to seasonal variations in recharge and discharge. In areas of heavy pumpage, such as Fort Rucker, Ozark, and Dothan, fluctuations of the potentiometric surface also reflect the variations in rates of withdrawals.

A water-level recorder was installed on an unused municipal well (well 24) at Ozark in 1982 to monitor fluctuations of the potentiometric surface in the lower aquifer (Ripley Formation). Figure 11 shows fluctuations of the water surface in the well from February 1982 through March 1983. The figure also shows average daily pumpage per month by the city of ozark and total monthly precipitation at Eufaula wildlife Refuge (about 50 miles northeast of Fort Rucker in the outcrop area of the lower aquifer). Comparison of the three graphs in figure 11 indicates that the potentiometric surface of the lower aquifer at ozark is affected more by pumpage from the aquifer than by recharge. However, recharge apparently had some effect on the potentiometric surface during the winter of 1982-83 because the water surface was higher in February 1983 than in February 1982. Rainfall records of the National weather Service indicate that precipitation was generally below normal during the winter of 1981-82, and was generally above normal during the winter of 1982-83. 

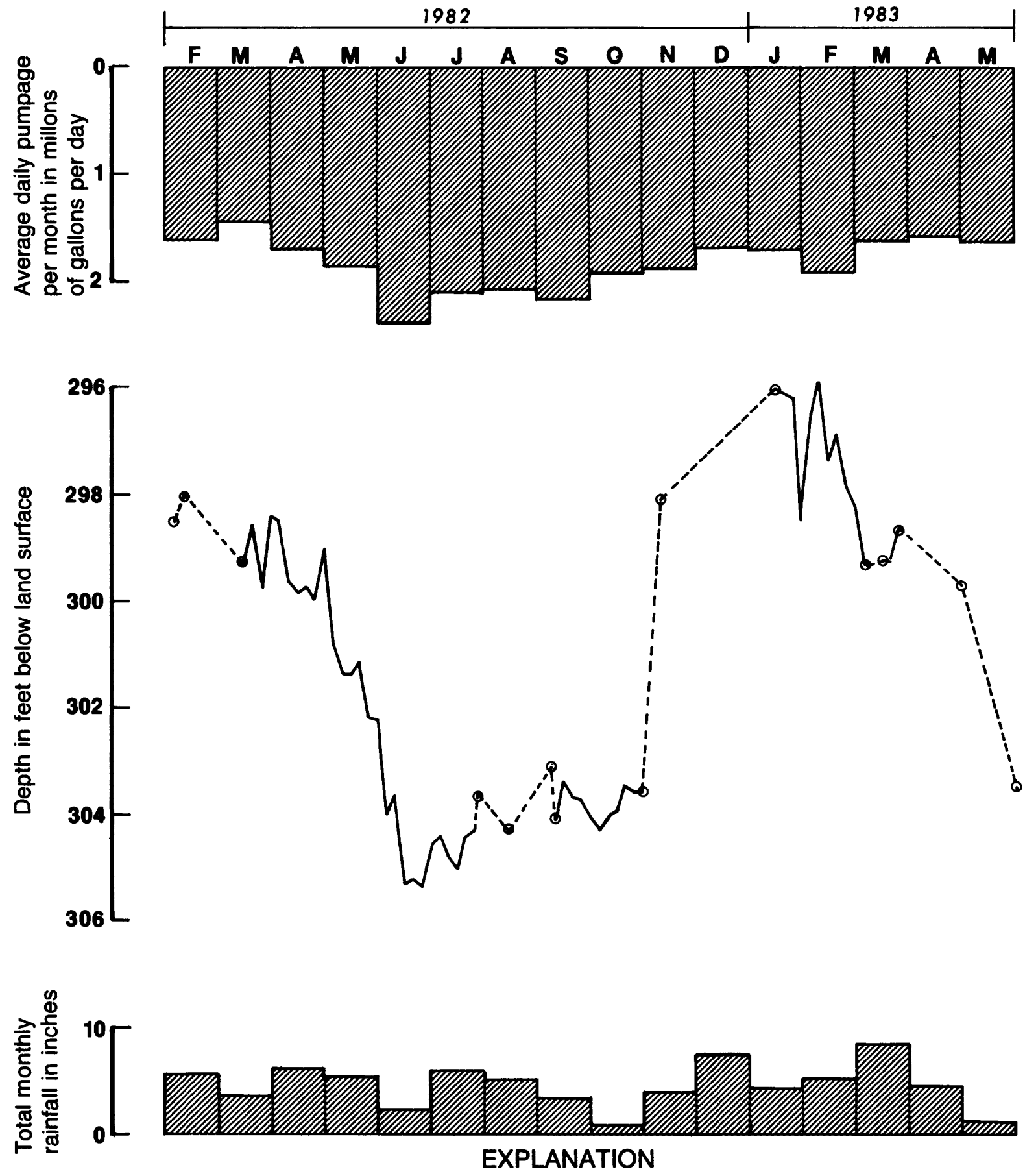

Water level measurement
or recorded water level

— Continuous graphic record

----- Missing Record

Figure 11.--Fluctuation of the water level in well 24 (lower aquifer), average daily pumpage at Ozark, and total monthly precipitation at Eufaula Wildlife Refuge during 1982-83. 
Historical water-level data were recorded for the study area as early as 1895 (Smith, 1906). Smith published water-level data that were obtained between 1895 and 1905. Additional water-level data were published in the 1940's (LaMoreaux, 1948) and in the 1960's in the county water-availability reports. These data and data collected during the current study indicate that the most significant declines in the potentiometric surface occurred after 1965.

Waterworks personnel at Fort Rucker have measured water levels in the original Fort Rucker wells periodically since the wells were constructed. These data, shown graphically in figure 12, indicate that the largest waterlevel declines at Fort Rucker occurred between 1976 and 1982. This accelerated decline resulted from increased water use at Fort Rucker (oral commun., Mr. John Ard, Fort Rucker Waterworks Manager, 1982). Mr. Ard reported that during summer months from 1977 to 1981 the demand for water exceeded the capacity of the well field and the use of water at Fort Rucker had to be restricted.

A potentiometric map of the upper aquifer in the study area is shown in figure 13. The map is compiled mainly from water-level measurements made in June and July 1982. Depressions in the potentiometric surface have developed in the Dothan area, the Battens Crossroads area, and the Fort RuckerEnterprise area. These depressions result from long-term withdrawals of large amounts of water. Before wells 70, 72, and 79 (Fort Rucker wells 9, 8, and 10) were installed, a depression had formed in the vicinity of Fort Rucker's well field. After these wells were placed in service in 1981-82, the original wells were idle most of the time and the water surface recovered about 20 feet. This recovery resulted from pumping the new wells which are 5,000 feet or more apart as opposed to the previous pumpage from the original wells which are about 2,000 feet apart. The recovery of the water level is temporary, and a depression will probably develop around the new wells in future years. The system can withstand a deeper cone of depression than the one that developed around the original well field because the pumps are set deeper in the new wells.

\section{Effects of Withdrawals on the Aquifer System}

Prior to development by wells, aquifers are in a steady state because, over a long period of time, recharge is equal to discharge (Lohman, 1972). Discharge from wells upsets this balance by causing a loss from storage. The imbalance remains until there is no further loss from storage. The loss from storage can be counterbalanced only by an increase in recharge, a decrease in natural discharge, or a combination of the two, as long as pumpage continues.

Available hydrologic data indicate that water levels in the pumping centers are continuing to decline. No significant decrease in streamflow or decline in water levels is apparent in the recharge area and, according to records of the National Weather Service, rainfall during the past 20 years was about normal. Based on these data the aquifer system has not reached a new state of equilibrium subsequent to withdrawals from the pumping centers. 


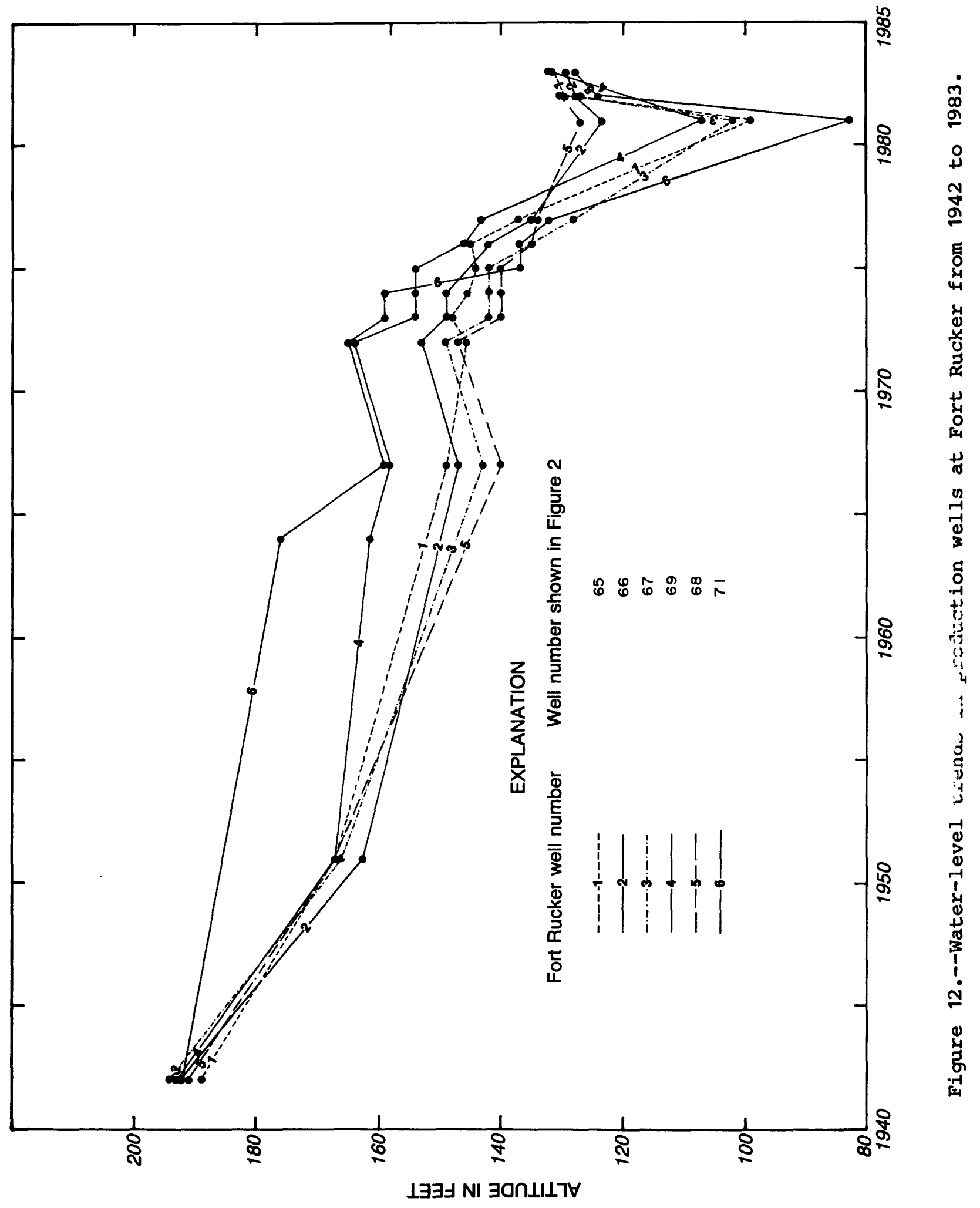


The depression around the pumping centers will continue to increuse in size until drawdowns from pumpage lower water levels sufficiently to increase the amount of water entering the aquifers to offset the pumpage. Through the use of the potentiometric map, a rough estimation of the rate of increase needed to attain a new equilibrium can be made. Flow paths for ground-water movement can be drawn on the potentiometric surface to determine the area from which pumpage in the study area obtains its water (fig. 14). The intersection of the area of diversion with the outcrop-area of the aquifer determines the contributing area (recharge area) for the pumpage. An estimate of the additional recharge needed to attain equilibrium can be made by dividing the pumpage (expressed in acre-inches per year) by the area of recharge (in acres). Pumpage is $33 \mathrm{Mgal} / \mathrm{d}(443,577$ acre-inches per year) for the area of diversion and the recharge area equals about $400 \mathrm{mi}^{2}(256,000$ acres). The resultant rate is about $1.75 \mathrm{in} / \mathrm{yr}$ that must be supplied to attain a new equilibrium. This rate appears to be a reasonable value, but available data are inadequate to ascertain if the transmissivity of the aquifer is sufficiently high to support the gradient of the potentiometric surface to induce that amount of recharge. Based on the single transmissitivity value for the aquifer, natural recharge would be about $1.4 \mathrm{in} / \mathrm{yr}$ under the present groundwater gradient. A steeper gradient induced by pumpage would increase the rate of water-movement through the aquifer and enable a greater amount of water to be recharged. To reach a new state of equilibrium, the additional water would have to be captured from the sources of discharge in the recharge area, evapotranspiration and streamflow, or from a reduction in withdrawals in the pumping centers. Reduction of evapotranspiration would not cause any adverse effects but reduction of streamflow could cause problems during dry periods. Reduction in pumpage is not expected to occur in the foreseeable future.

\section{QUALITY OF WATER}

Field determinations for specific conductance, $\mathrm{pH}$, and temperature were made for most wells inventoried during the current study. No laboratory chemical analyses were made.

The specific conductance of water from wells sampled ranges from 220 to 540 micromhos per centimeter at $25^{\circ}$ Celsius. The pH ranges from 6.1 to 8.1 units and has a median of about 7.2 units. The temperature ranges from $19^{\circ} \mathrm{C}$ (Celsius) or $66^{\circ} \mathrm{F}$ (Fahrenheit) to $26.5^{\circ} \mathrm{C}$ or $80^{\circ} \mathrm{F}$. More detailed waterquality data are published in the water-availability reports for Coffee, Dale, Geneva, Henry, and Houston Counties. Additional water-quality data are available in the files of the U.S. Geological Survey and the Alabama Department of Environmental Management, Water Division. 


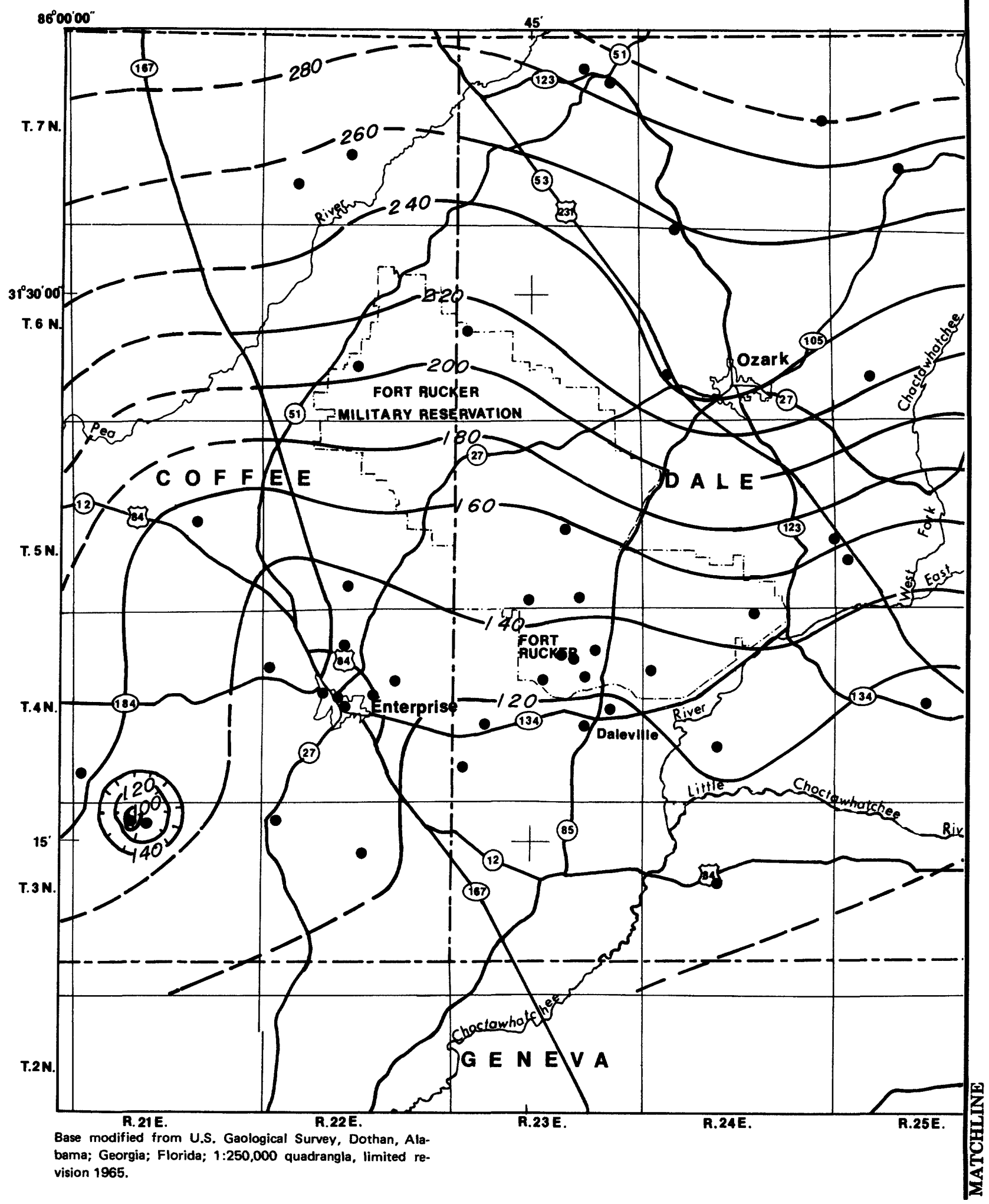

Figure 13.--Potentiometric surface of the upper aquifer in the study area in 1982. 


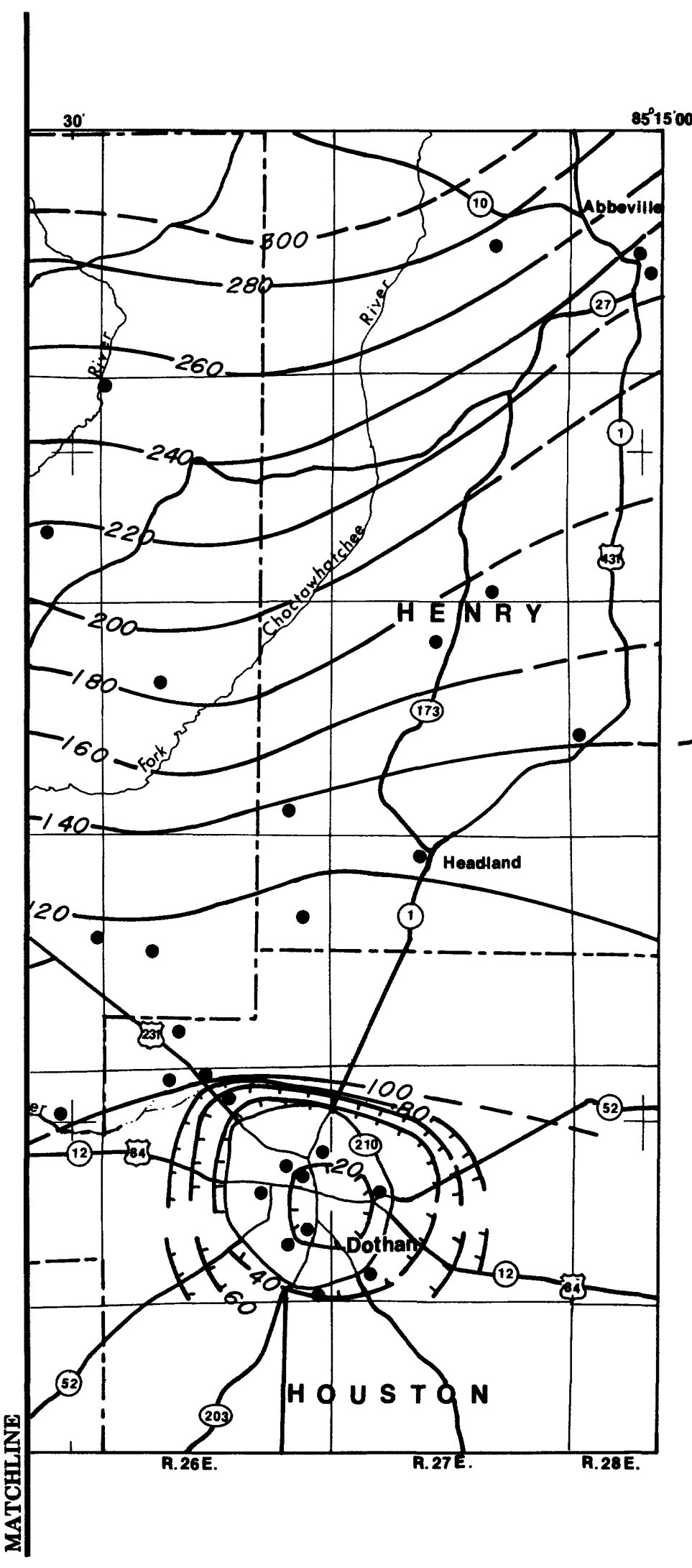

\section{EXPLANATION}

Potentiometric contour shows altitude of the potentiometric surface for the -100- upper aquifer in the Fort Rucker area. Dashed where approximately located. Contour interval 20 feet.

im. Hachures indicate depressions. Datum is sea level.

- Well in which water level was measured in 1982.

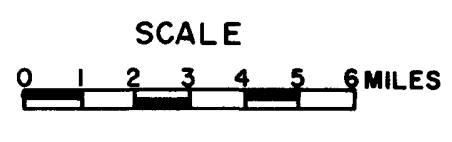



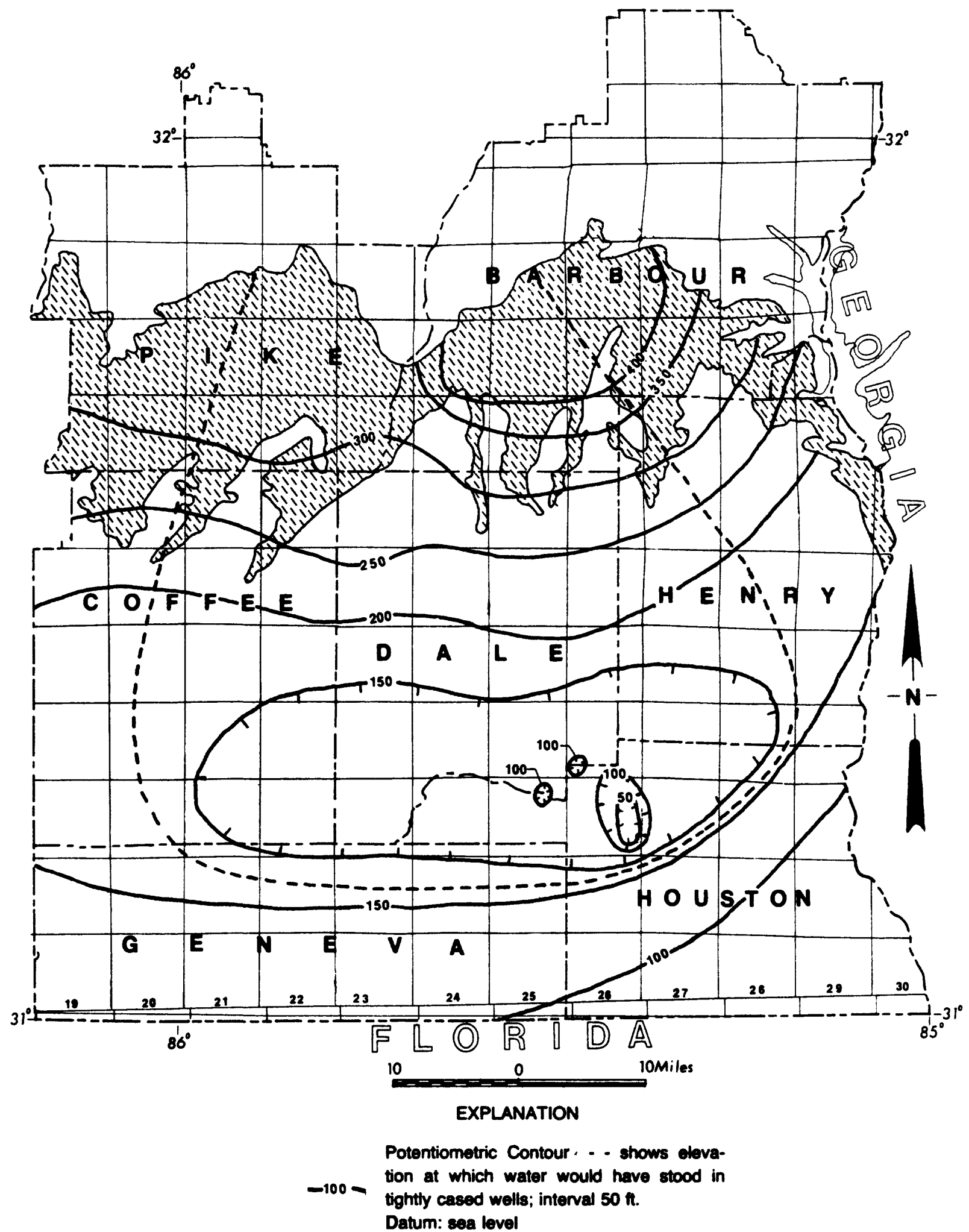

iil Area of outcrop for the upper aquifer

Outer limit of the area of diversion for ground-water pumpage in the study area.

Figure 14.--Areas of diversion and recharge for the upper aquifer. 
The Tertiary-Cretaceous aquifer system in the study area includes the basal sand in the Tuscahoma Sand, sand beds in the Nanafalia Formation, porous limestone and sand beds in the Clayton Formation, and sand beds in the Providence sand and the upper part of the Ripley Formation. For this report, this system is divided into an upper and lower aquifer. The upper aquifer consists of the Tuscahoma Sand, the Nanafalia Formation, the Clayton Formation, and the upper part of the Providence sand. The lower aquifer consists of the lower part of the Providence Sand and the Ripley Formation.

The aquifer test at Fort Rucker indicates that the upper aquifer has a transmissivity of about $7,800 \mathrm{ft}^{2} / \mathrm{d}$ and coefficient of storage of about $3 \times 10^{-4}$.

Wells too-closely spaced, causing excessive drawdown because of interference when pumped, appear to be the most common problem in the study area, especially at Dothan and Fort Rucker. Wider spacing for future wells and selective pumping from existing wells should alleviate the excessive drawdown problem.

Preliminary evaluation of the aquifer system indicates that the system is in a state of hydrologic imbalance as a result of heavy pumpage at Fort Rucker, Dothan, Ozark, and Enterprise during the past 40 years. A new state of equilibrium can be attained only by an increase in recharge to or by reducing discharge from the system.

Water-quality data collected during this study and data collected during previous studies indicate that water in the aquifer system is of good chemical quality and is suitable for municipal, domestic, irrigation, and some industrial uses.

Data collected during the study indicate that the aquifer system in the study area is a reliable source of water supply for current and future uses. However, sites for additional wells should be carefully selected to avoid mutual interference between wells. 
Adams, G. I., Butts, Charles, Stephenson, L. W., and Cooke, C. W., 1926, Geology of Alabama: Alabama Geological Survey Special Report 14, 312 p., $97 \mathrm{pls.,}$ including revised geologic map of Alabama.

Carter, R. W., and others, 1949, Water resources of southeastern Alabama: Alabama Geological Survey Special Report 21, 265 p.

Causey, L. V., Scott, J. C., and Newton, J. G., 1967, Geologic map of Houston County: Alabama Geological Survey Special Map 58.

Ferris, J. G., and others, 1962, Theory of aquifer tests: U.s. Geological Survey Water Supply Paper 1536-E, $171 \mathrm{p}$.

Knowles, D. B., Reade, H. L., Jr., and Scott, J. C., 1963, Geology and groundwater resources of Montgomery County, Alabama: U.S. Geological survey Water-Supply Paper 1606, 75 p.

LaMoreaux, P. E., 1948, Flouride in the ground water of the Tertiary area of Alabama: Alabama Geological Survey Bulletin 59, $77 \mathrm{p}$.

Lohman, S. W., 1972, Ground-water hydraulics: U.S. Geological survey Professional Paper 708, 70 p.

MacNeil, F. S., 1940, Geologic map of the Tertiary formations of Alabama: U.S. Geological Survey Preliminary Oil and Gas Investigations Map 45.

Monroe, W. H., 1941, Notes on deposits of Selma and Ripley age in Alabama: Alabama Geological Survey Bulletin 48, $150 \mathrm{p}$.

Newton, J. G., 1965, Geologic Map of Barbour County, Alabama: Alabama Geological Survey Special Map 33. 1968a,Geologic map of Dale County, Alabama: Alabama Geological Survey Special Map 63. 1968b, Geologic map of Henry County, Alabama: Alabama Geological Survey Special Map 70 .

Newton, J. G., Golden, H. G., Avrett, J. A., and Scott, J. C., 1968, Water availability, Dale County, Alabama: Alabama Geological Survey Special Map 64, $26 \mathrm{p}$.

Newton, J. G., MCCain, J. F., and Avrett, J. A., 1968, Water availability, Henry County, Alabama: Alabama Geological Survey Special Map 71, 14 p.

Sapp, C. D., and Emplaincourt, J., 1975, Physiographic regions of Alabama: Alabama Geological Survey Special Map 168.

Scott, J. C., 1966, Geologic map of Geneva County, Alabama: Alabama Geological Survey Special Map 54.

Scott, J. C., Golden, H. G., and Avrett, J. A., 1967, Water availability in Geneva County, Alabama: Alabama Geological Survey Special Map 55.

Scott, J. C., McCain, J. F., and Avrett, J.A., 1967, Water availability in Houston County, Alabama: Alabama Geological Survey Special Map 59.

Shamberger, V. M., 1968, Geologic map of Pike County, Alabama: Alabama Geological Survey Special Map 72 .

Smith, E. A., 1907, The underground water resources of Alabama: Alabama Geological Survey Monograph 6, 388 p.

Smith, E. A., Johnson, L. C., and Langdon, D. W., Jr., 1899, Report on the Geology of the Coastal Plain of Alabama: Alabama Geological Survey Special Report 6, 759 p.

Toulmin, L. D., LaMoreaux, P. E., 1963, Stratigraphy along the Chattahoochee River, connecting link between Atlantic and Gulf coastal plain: Alabama Geological Survey Reprint Series 4, 20 p. 
Toumey, Michael, 1858, Second biennial report on the geology of Alabama: Alabama Geological Survey Biennial Report 2, 292 p.

Turner, J. D., Scott, J. C., and Newton, J. G., 1965, Geological map of Coffee County, Alabama: Alabama Geological Survey Special Map 35.

Turner, J. D., Scott, J. C., Golden, H. G., and Avrett, J. A., 1968, Water availability, Coffee County, Alabama: Alabama Geological Survey Special Map 76. 


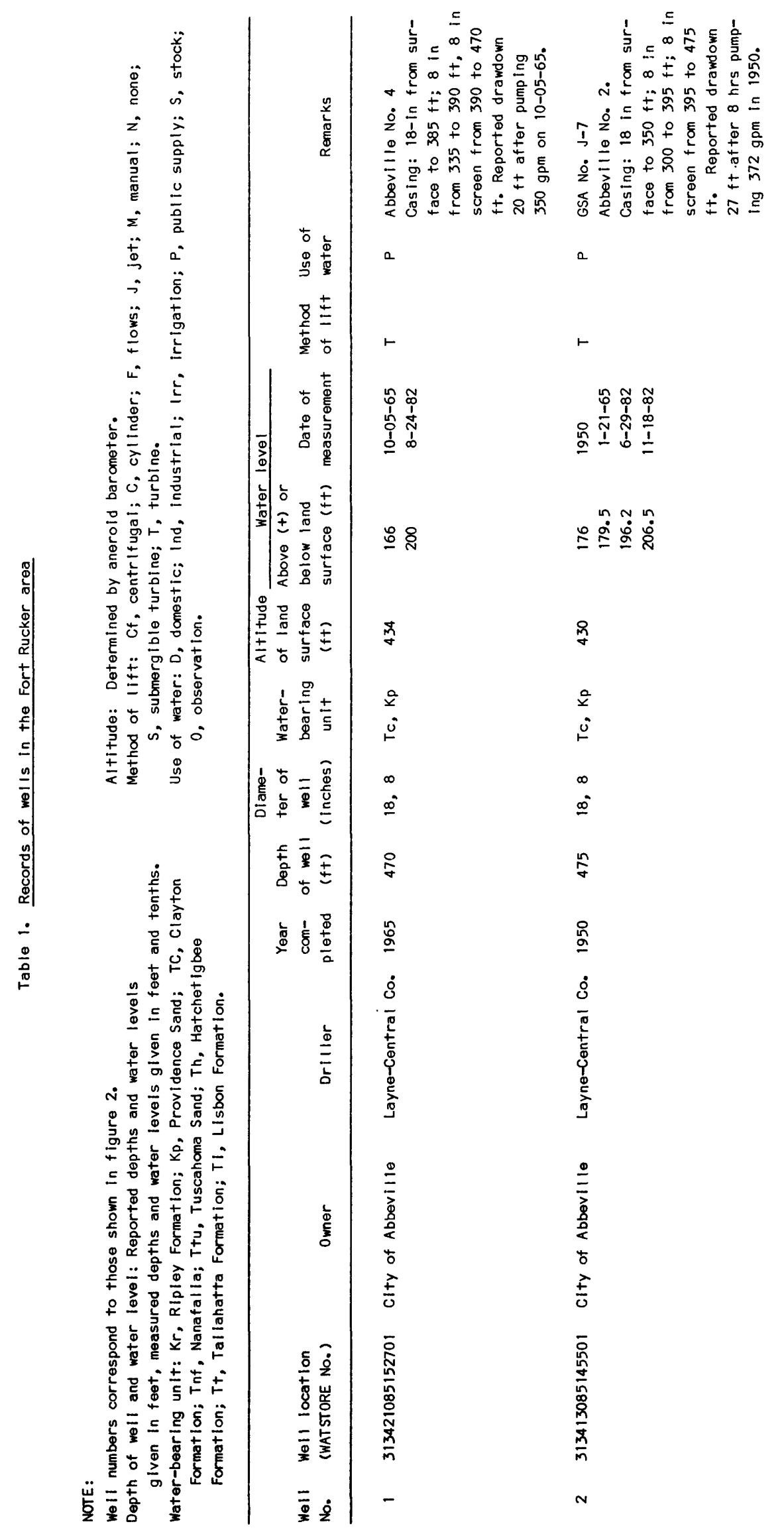




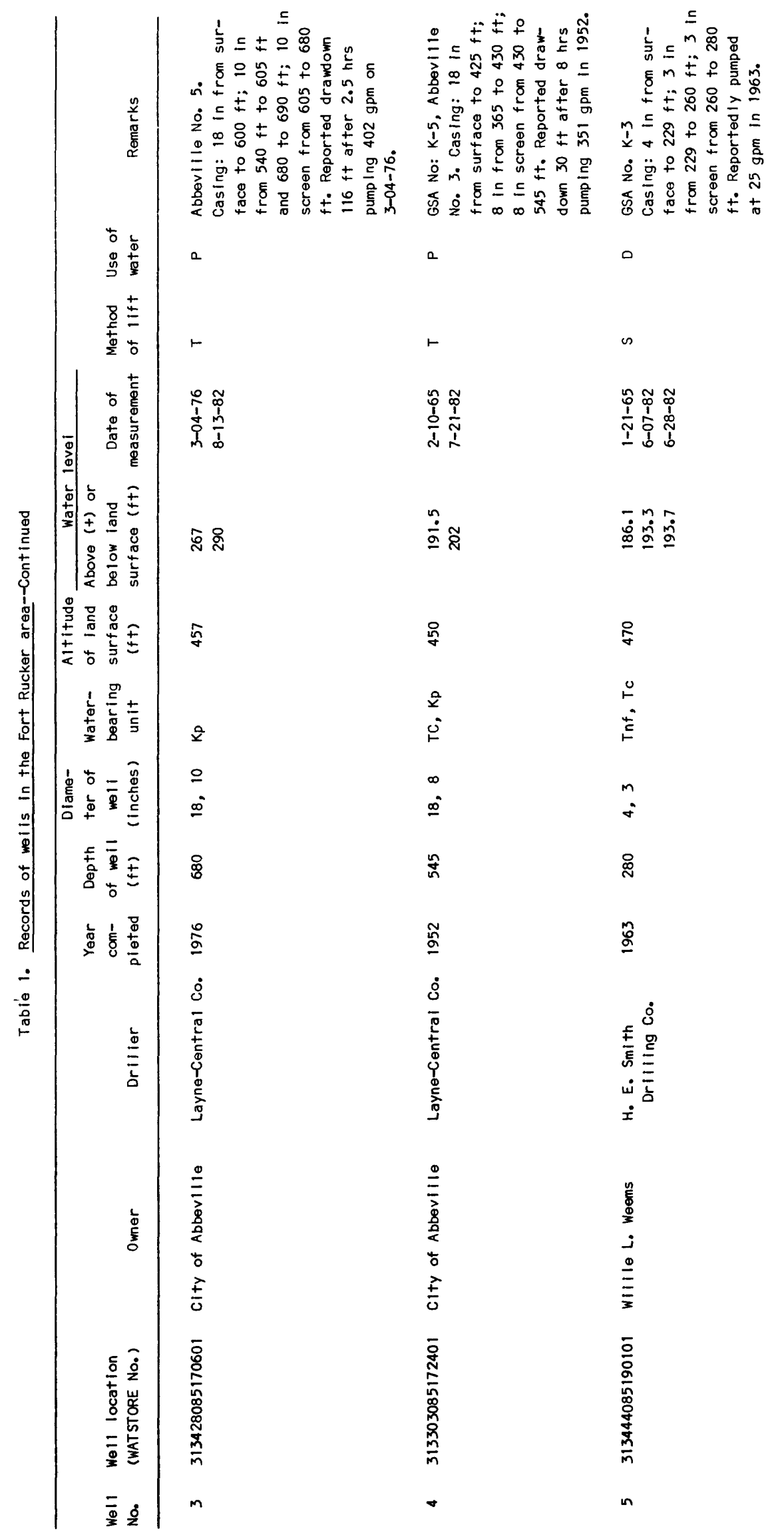




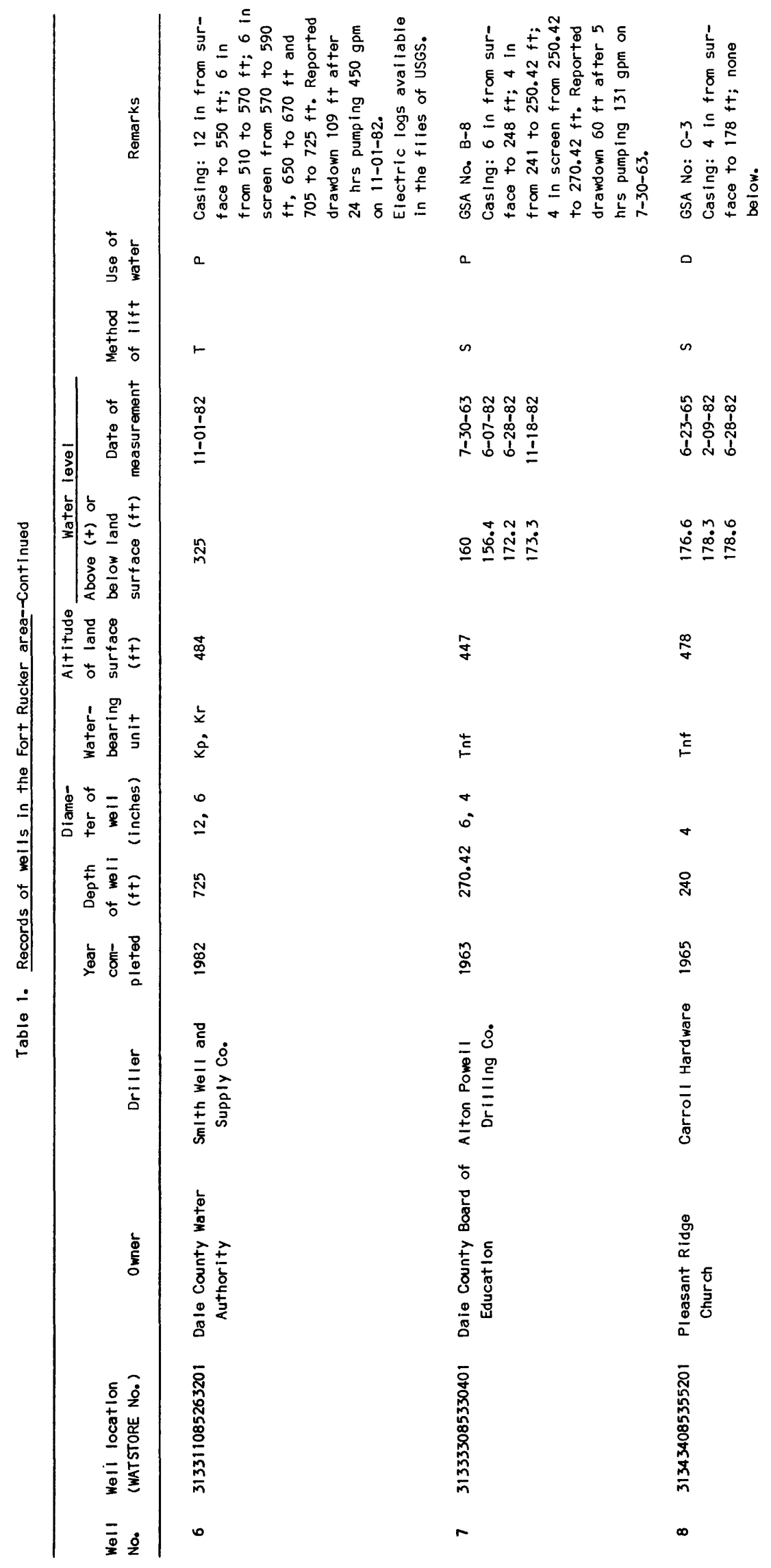




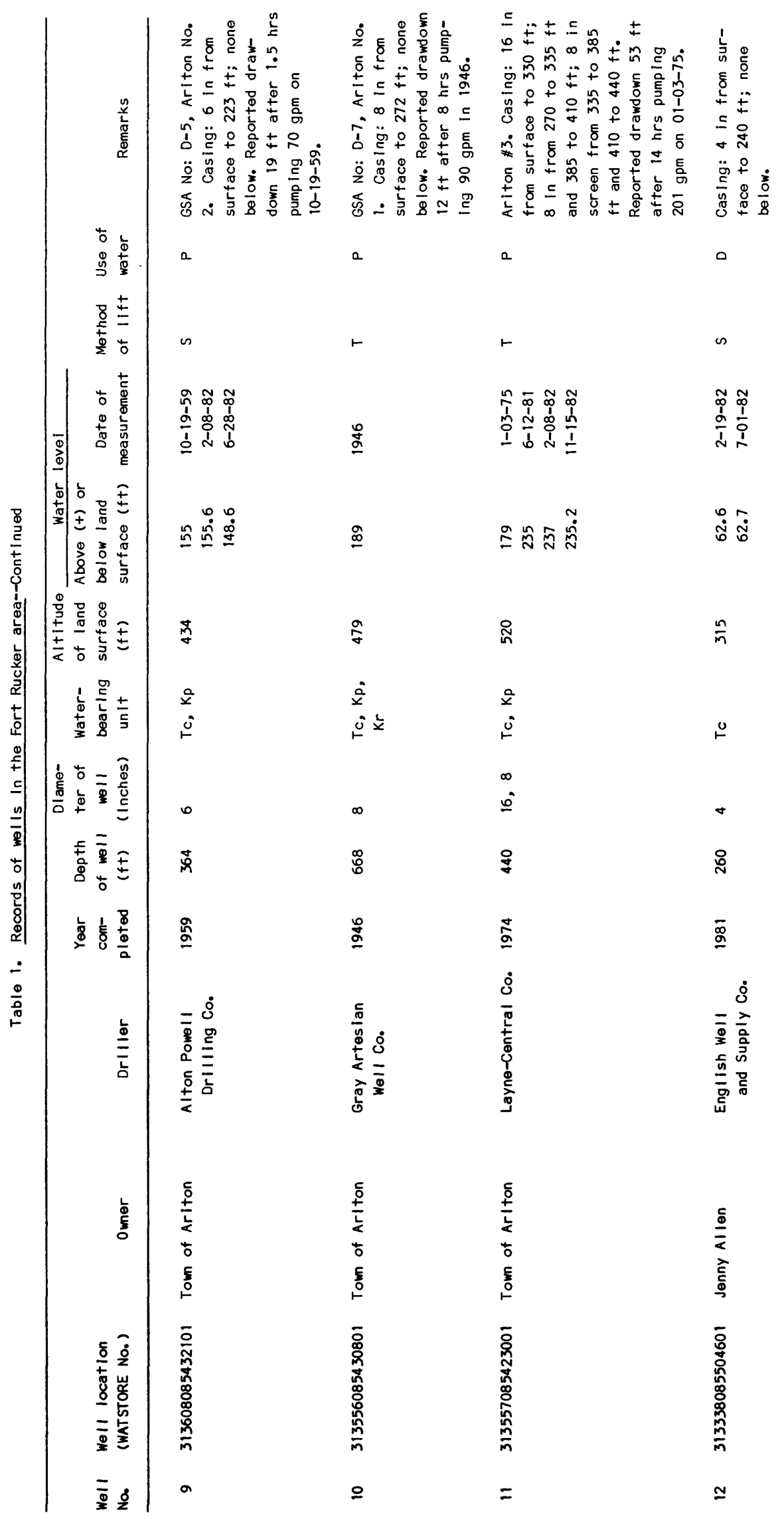




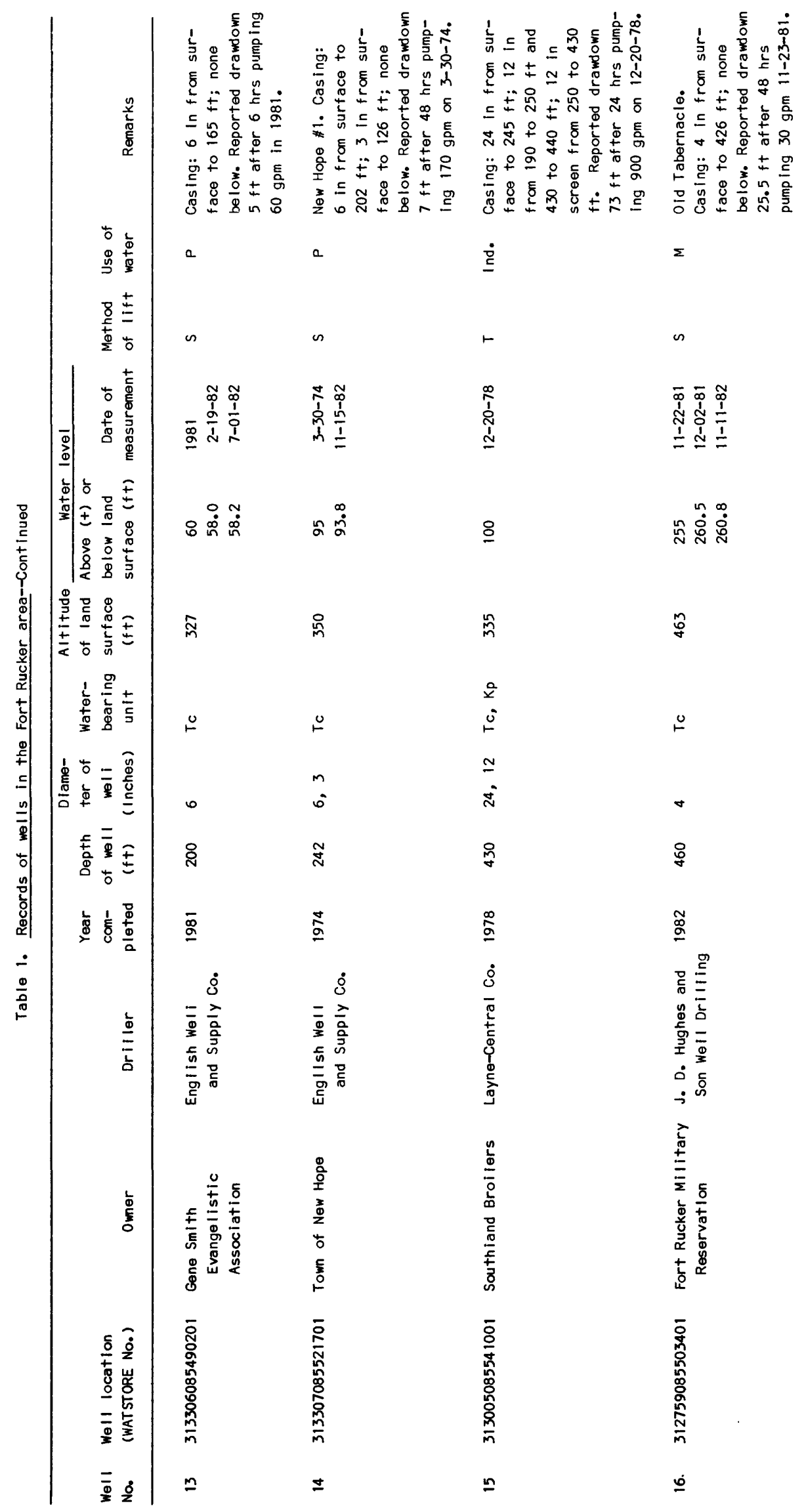




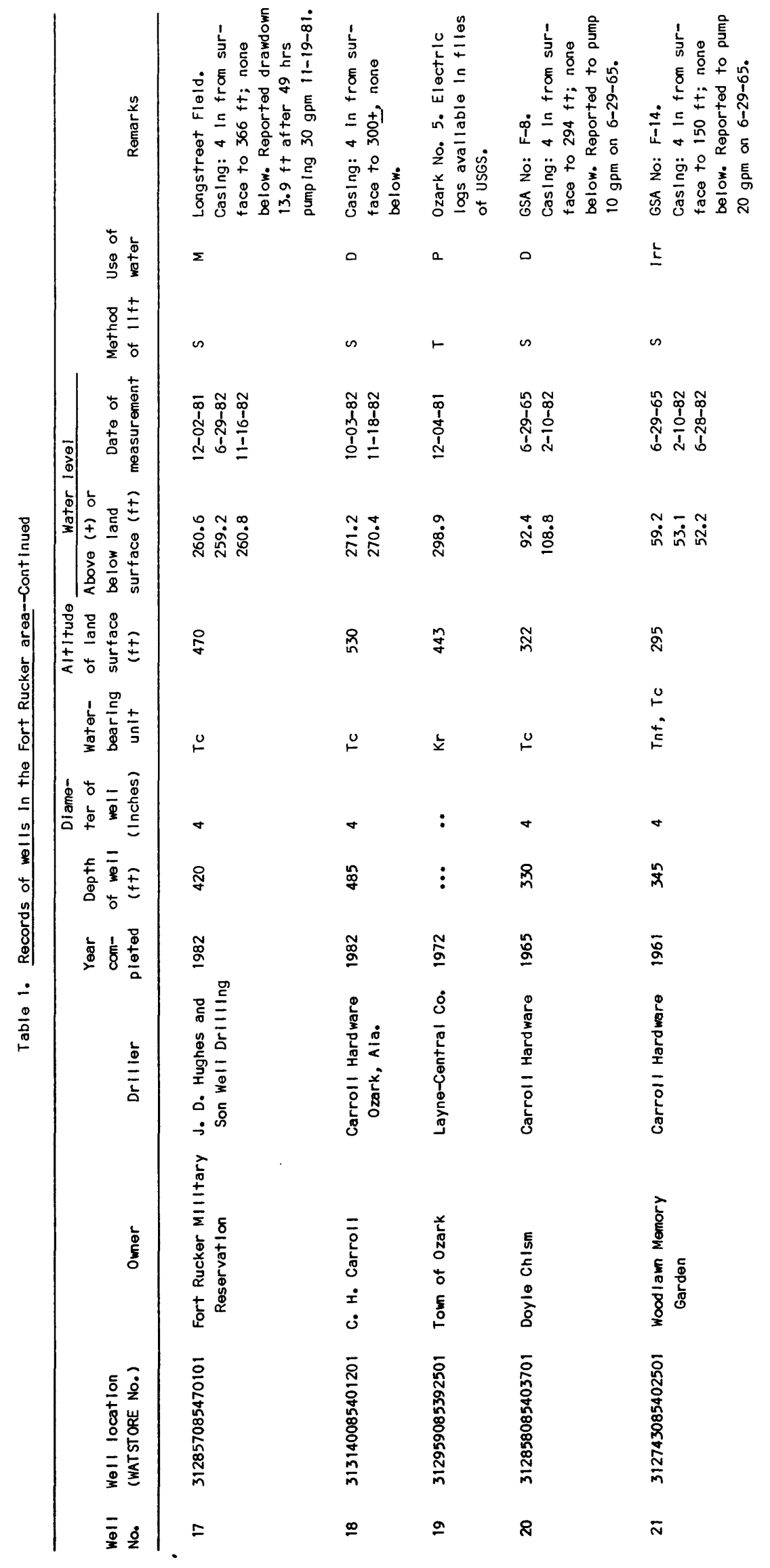




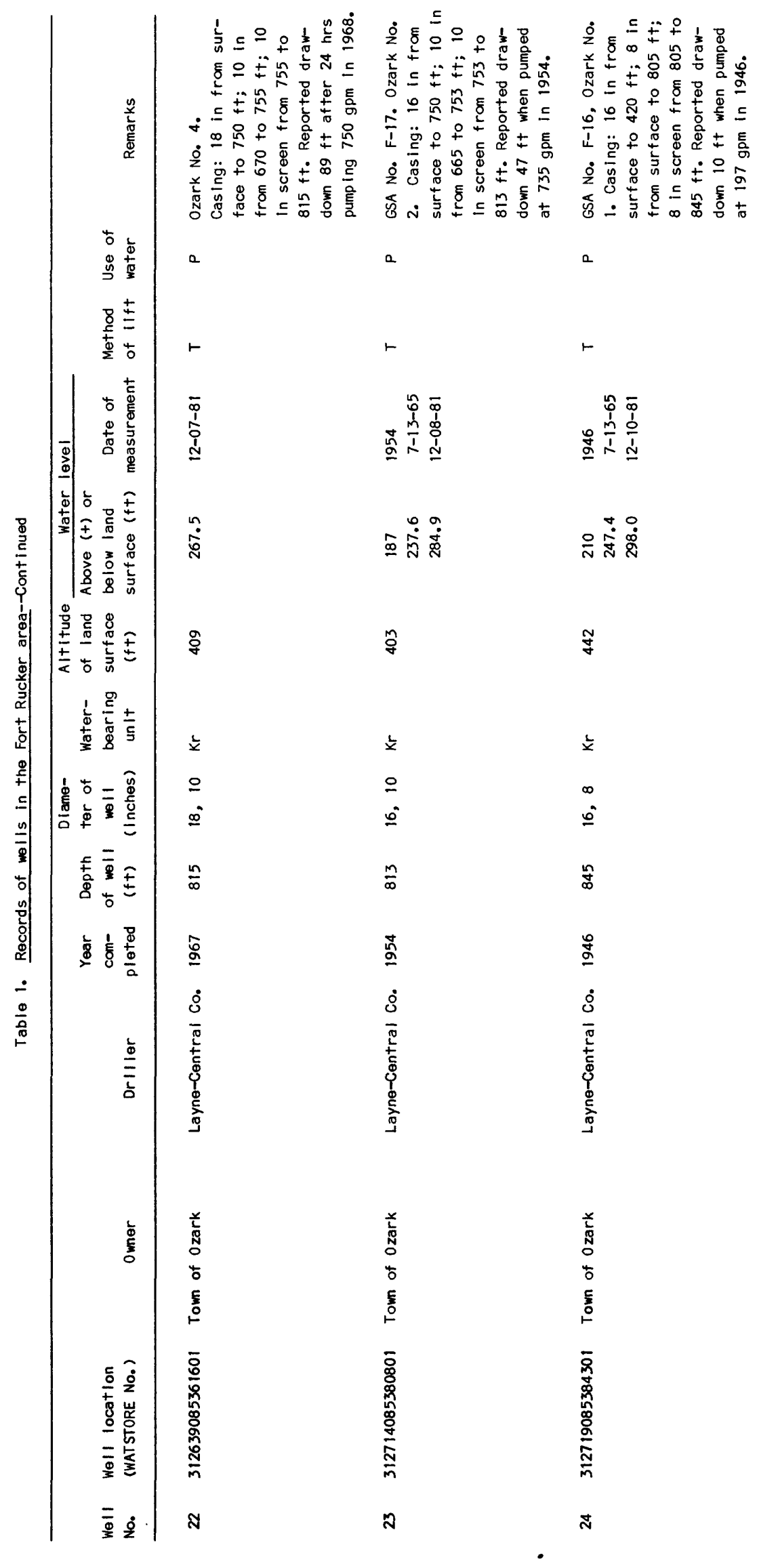




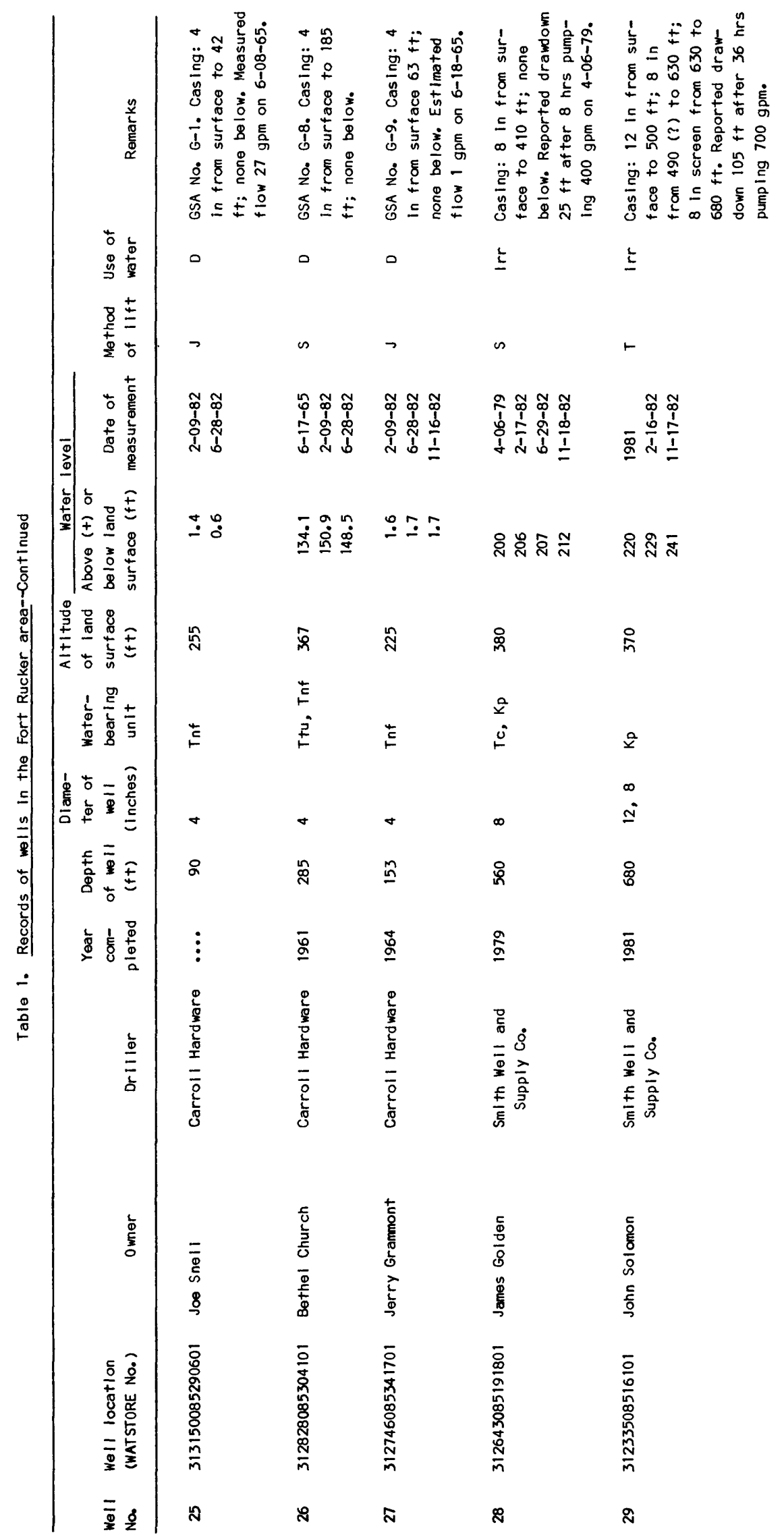




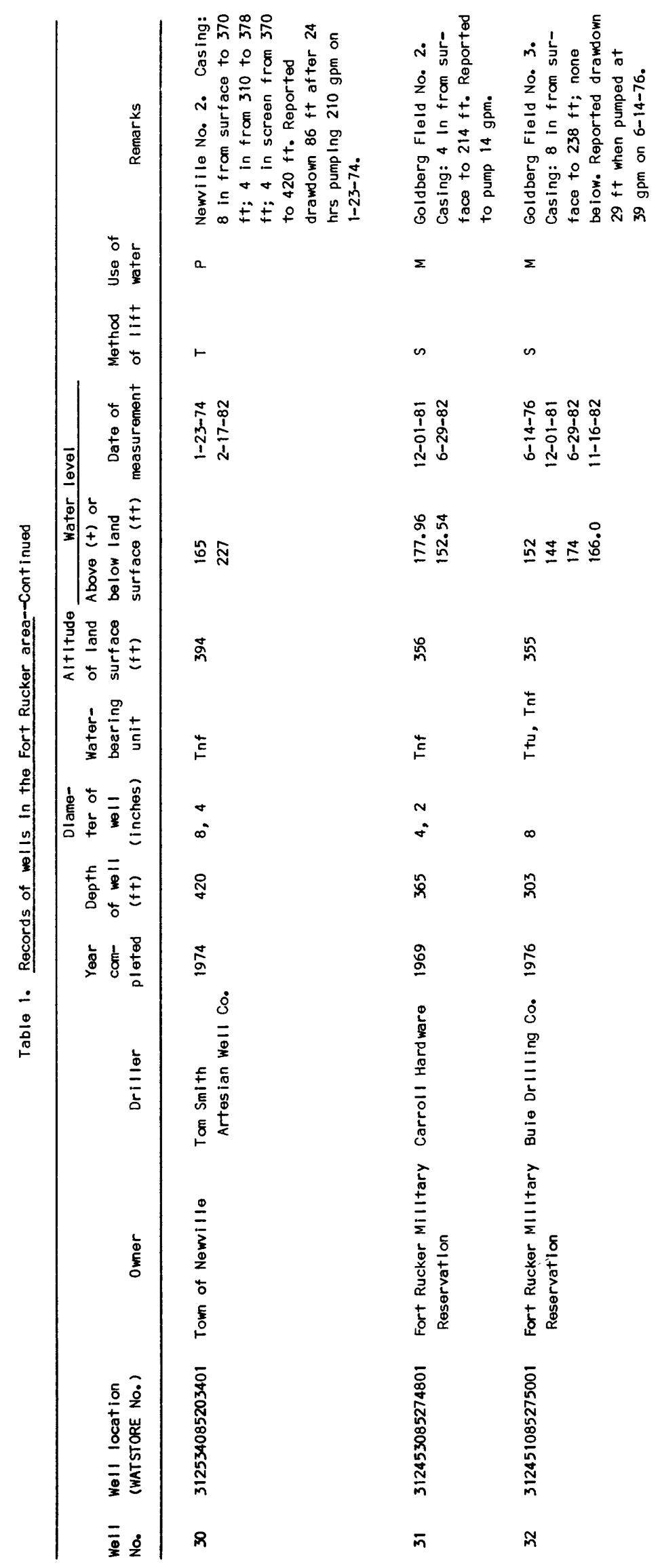




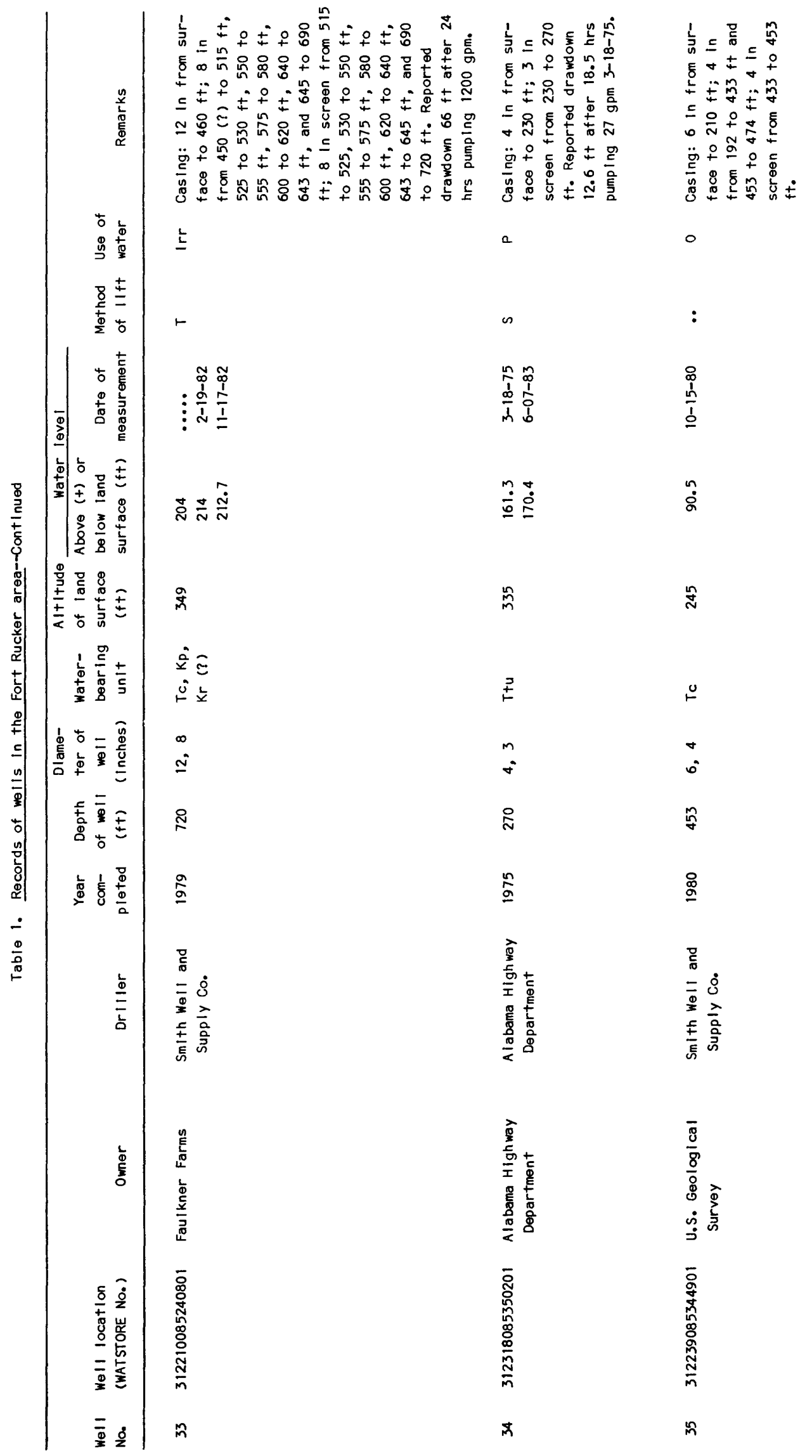




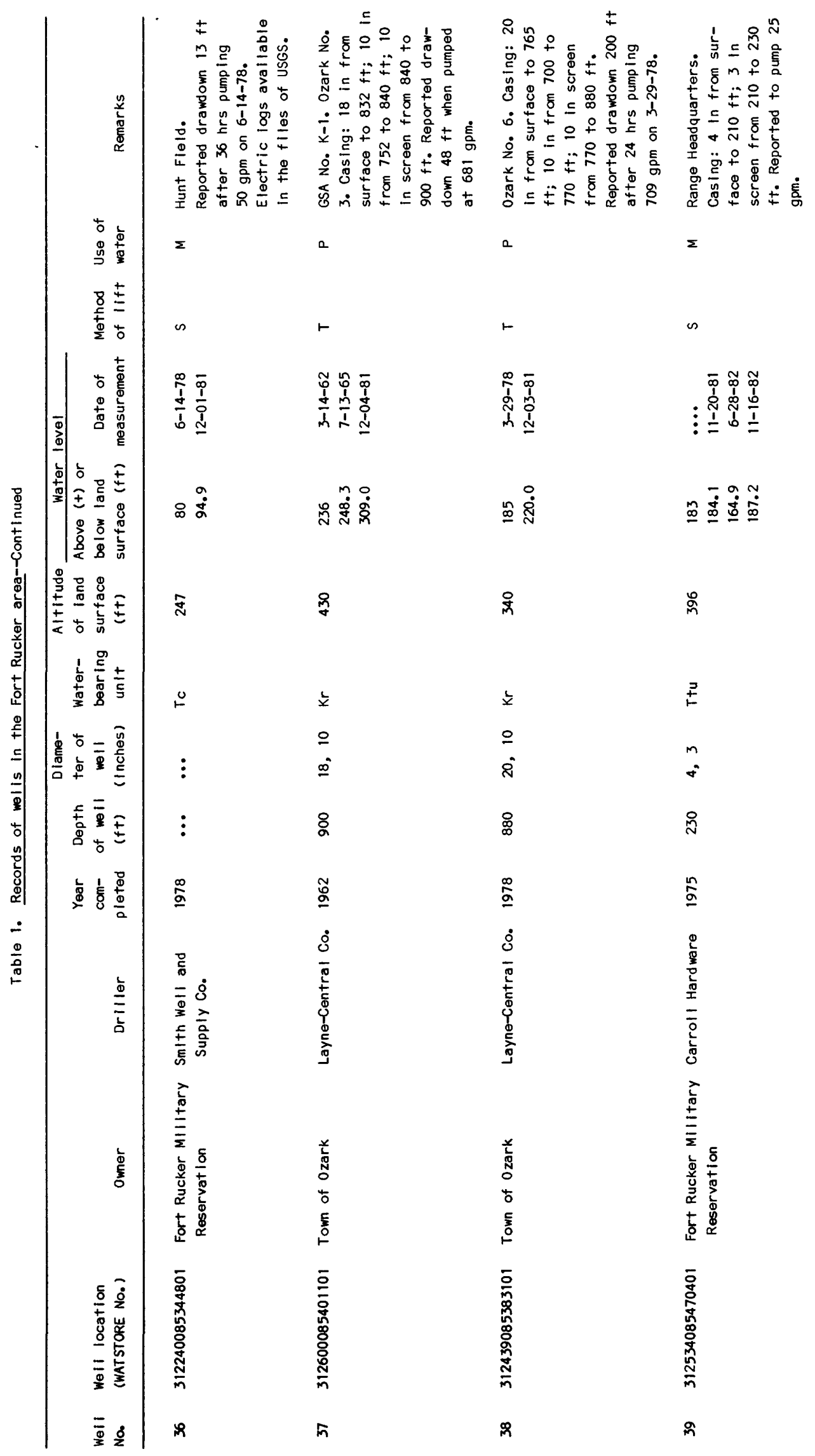




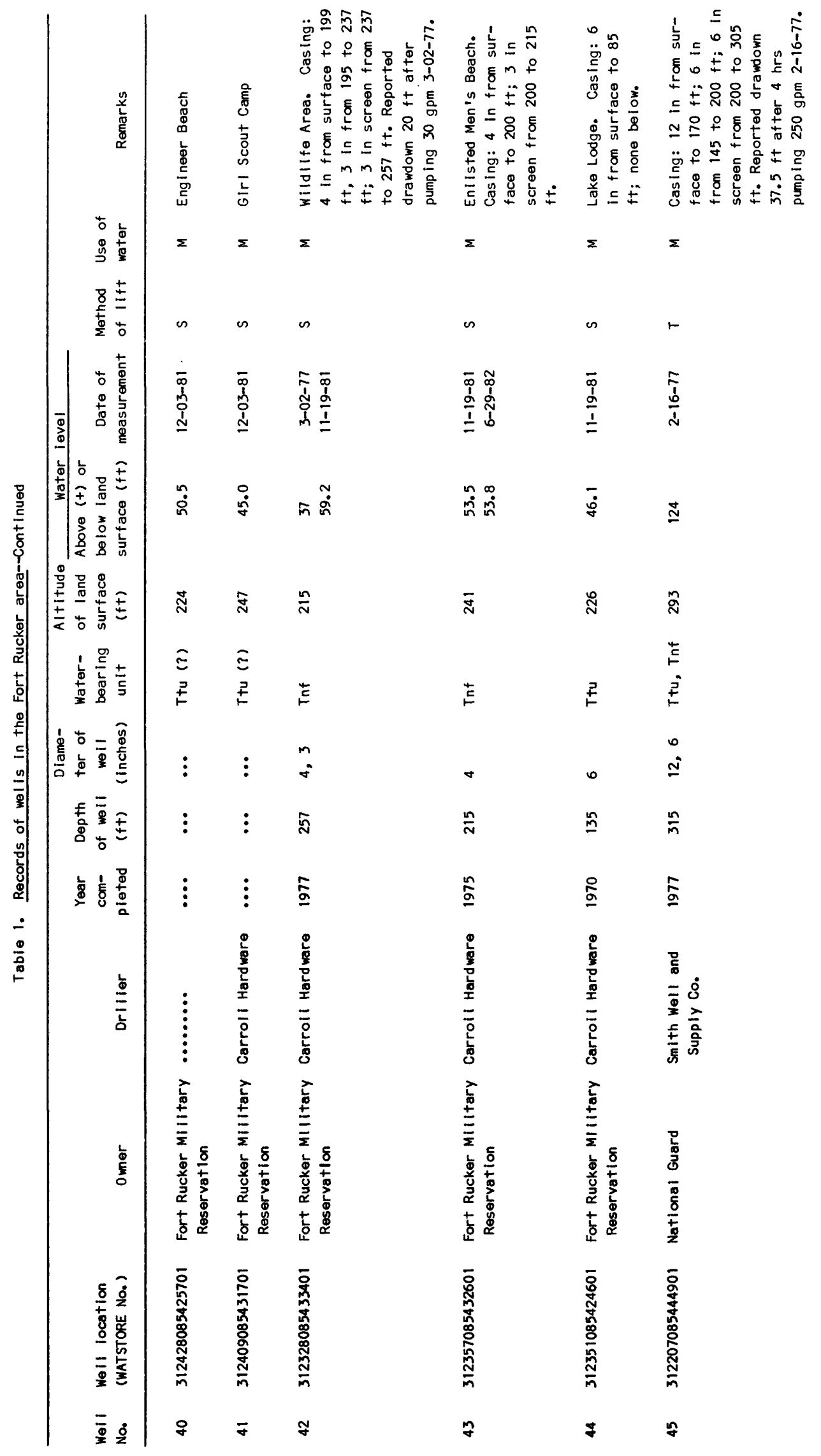




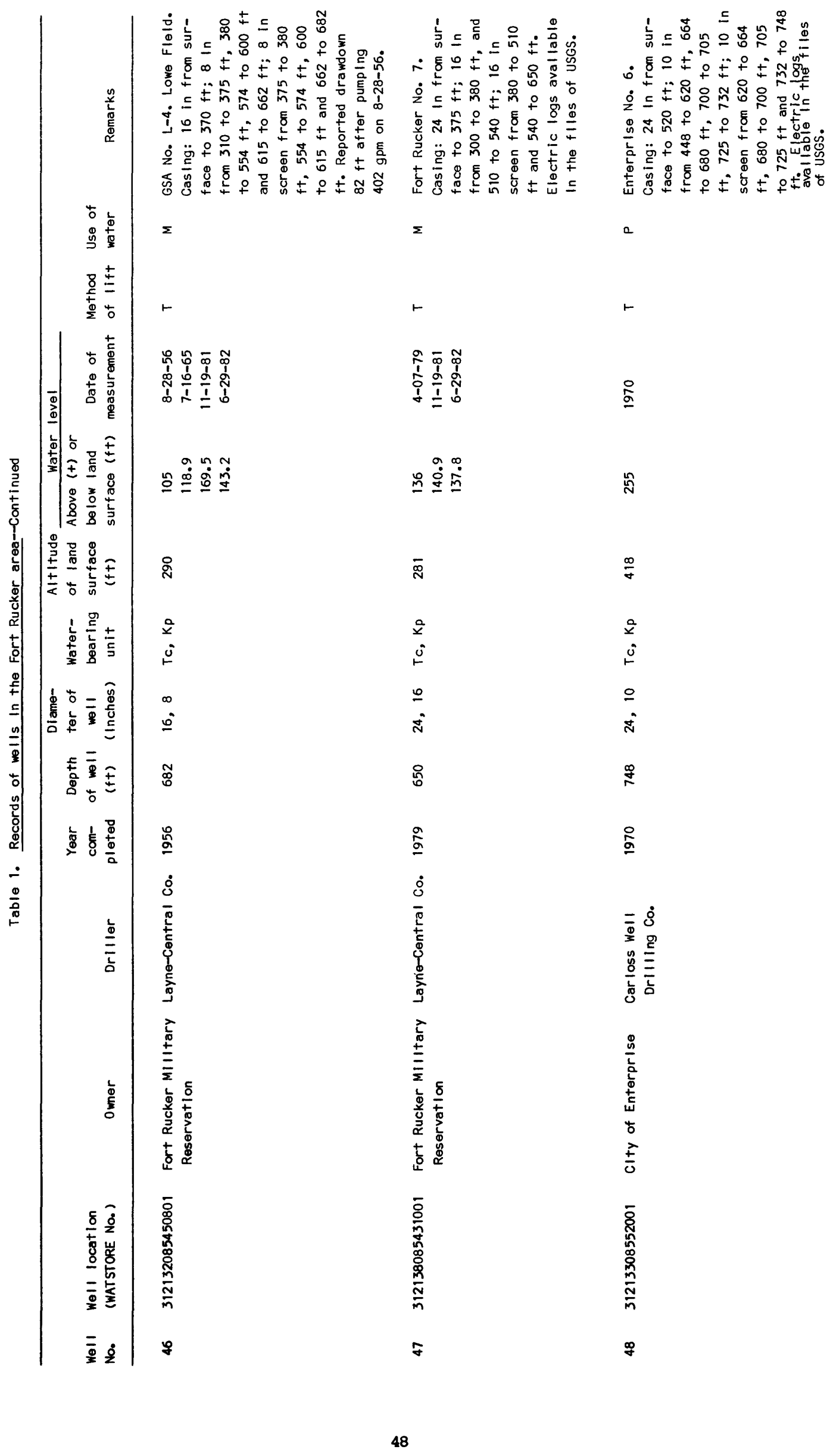




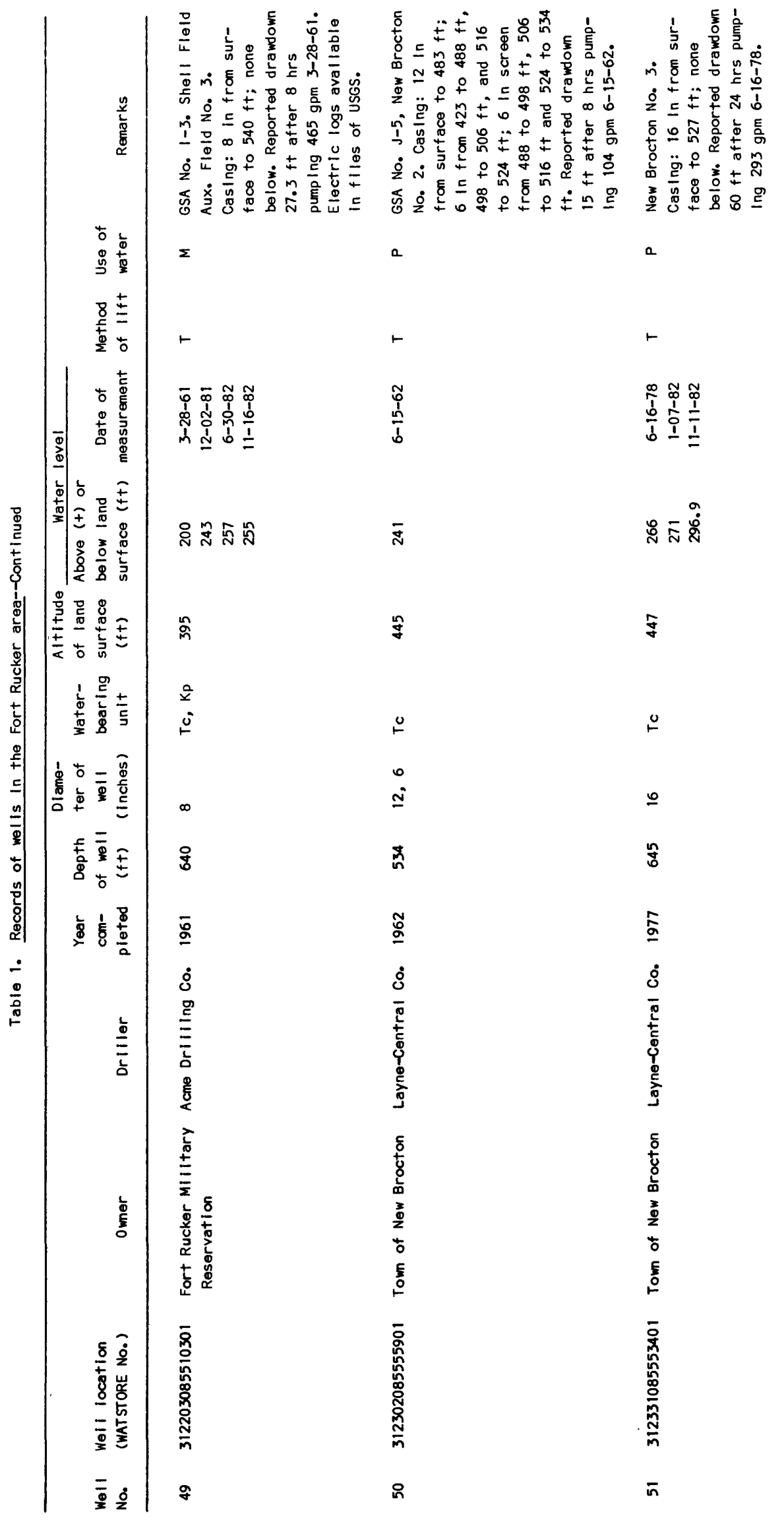




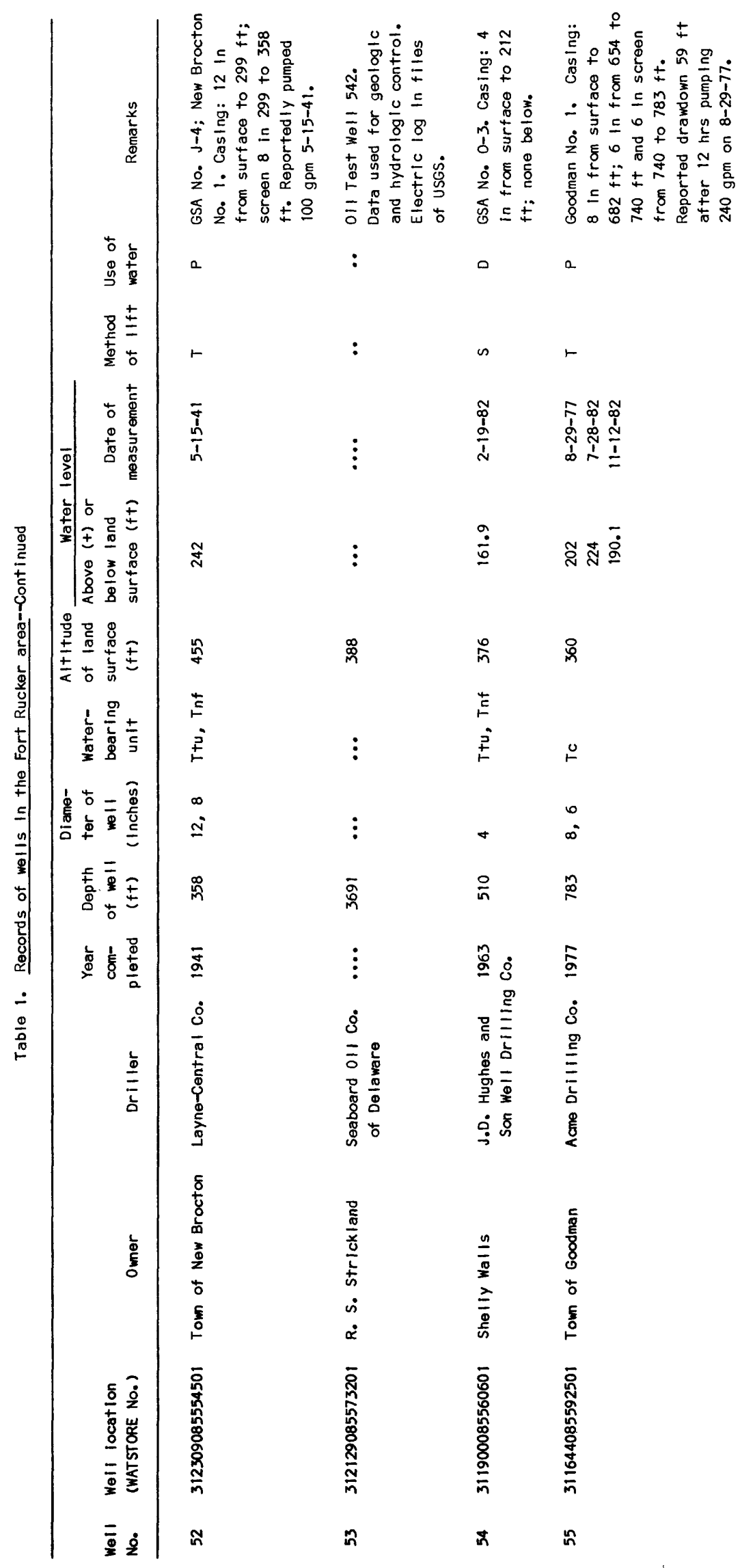




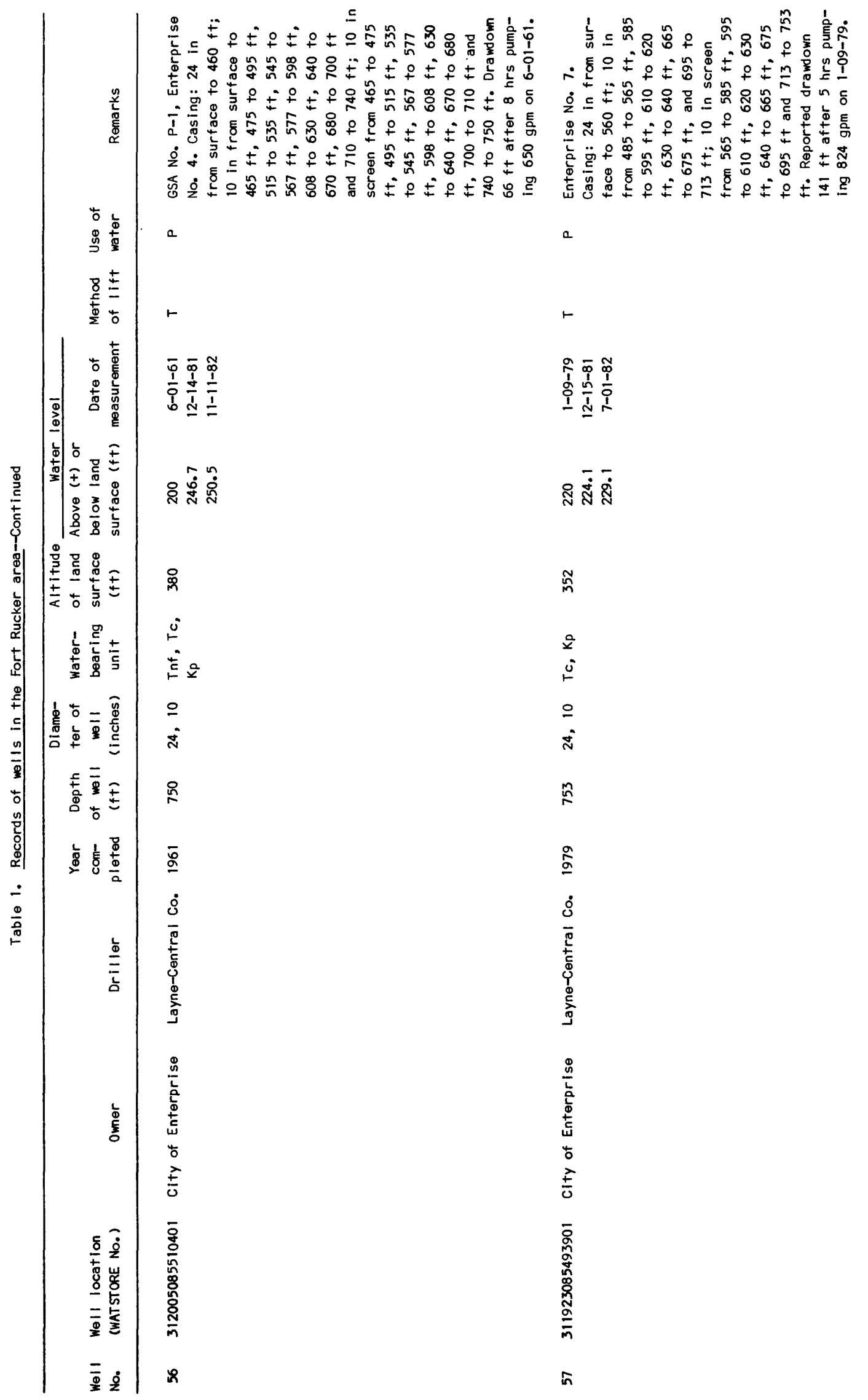




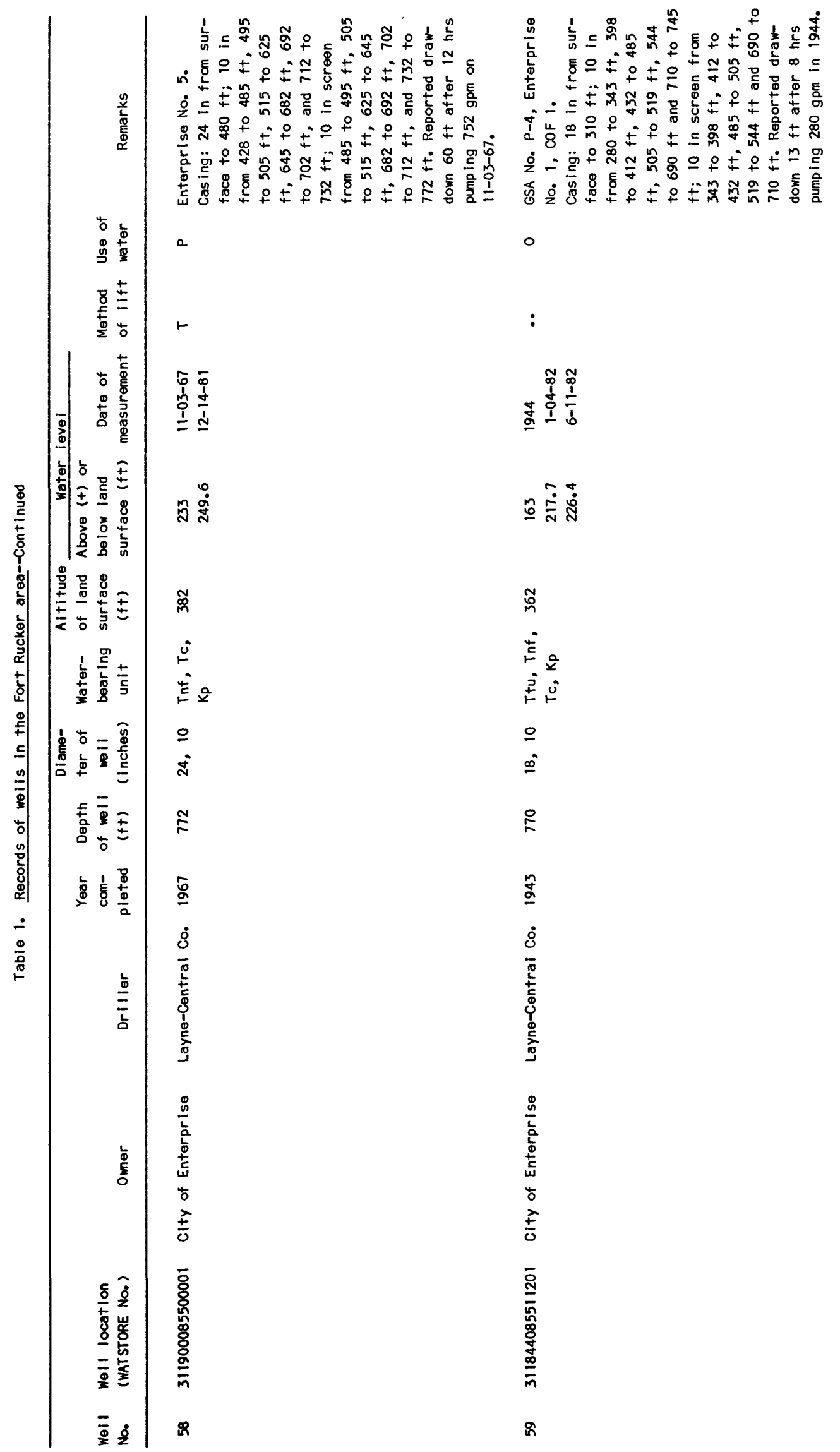




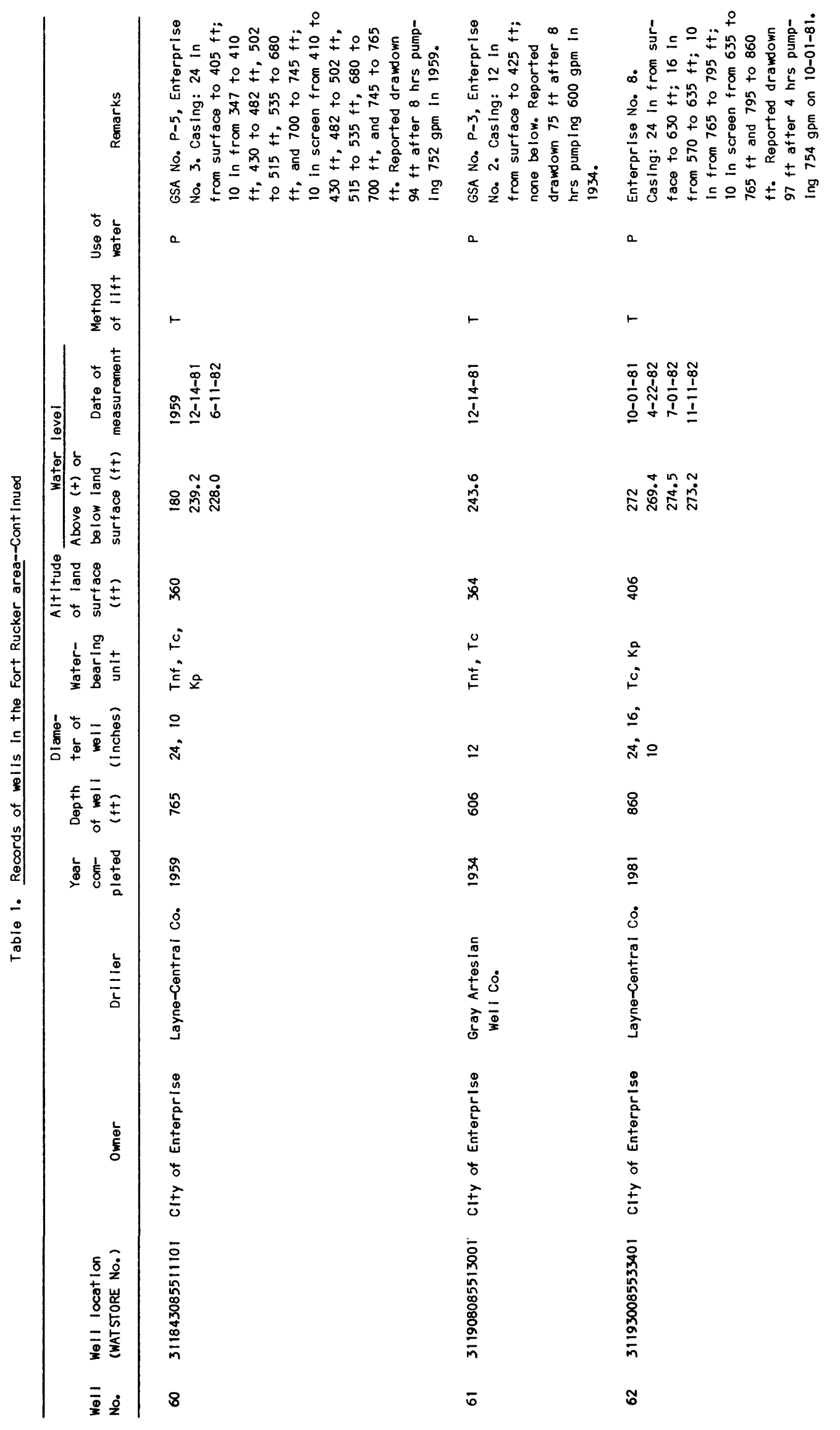




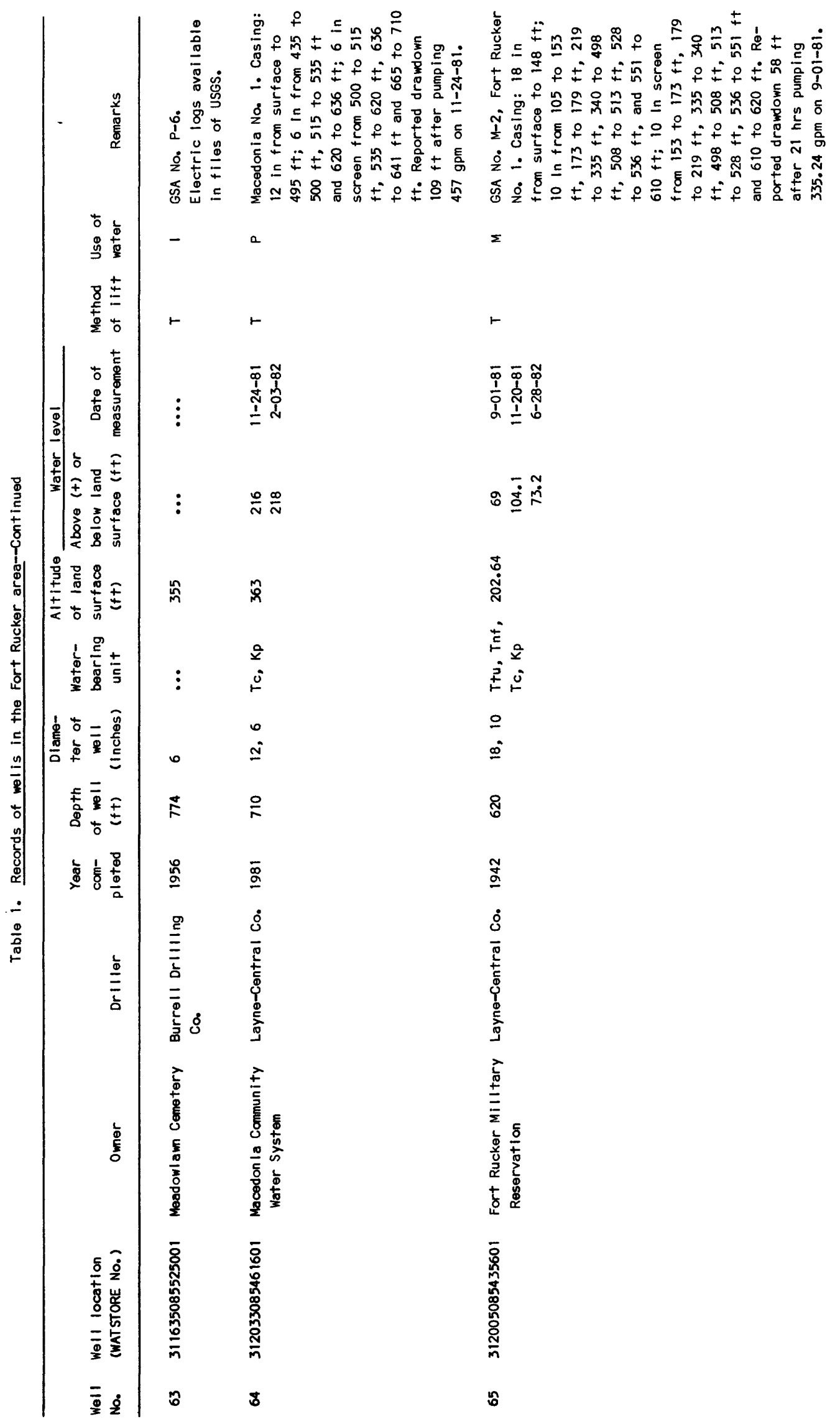




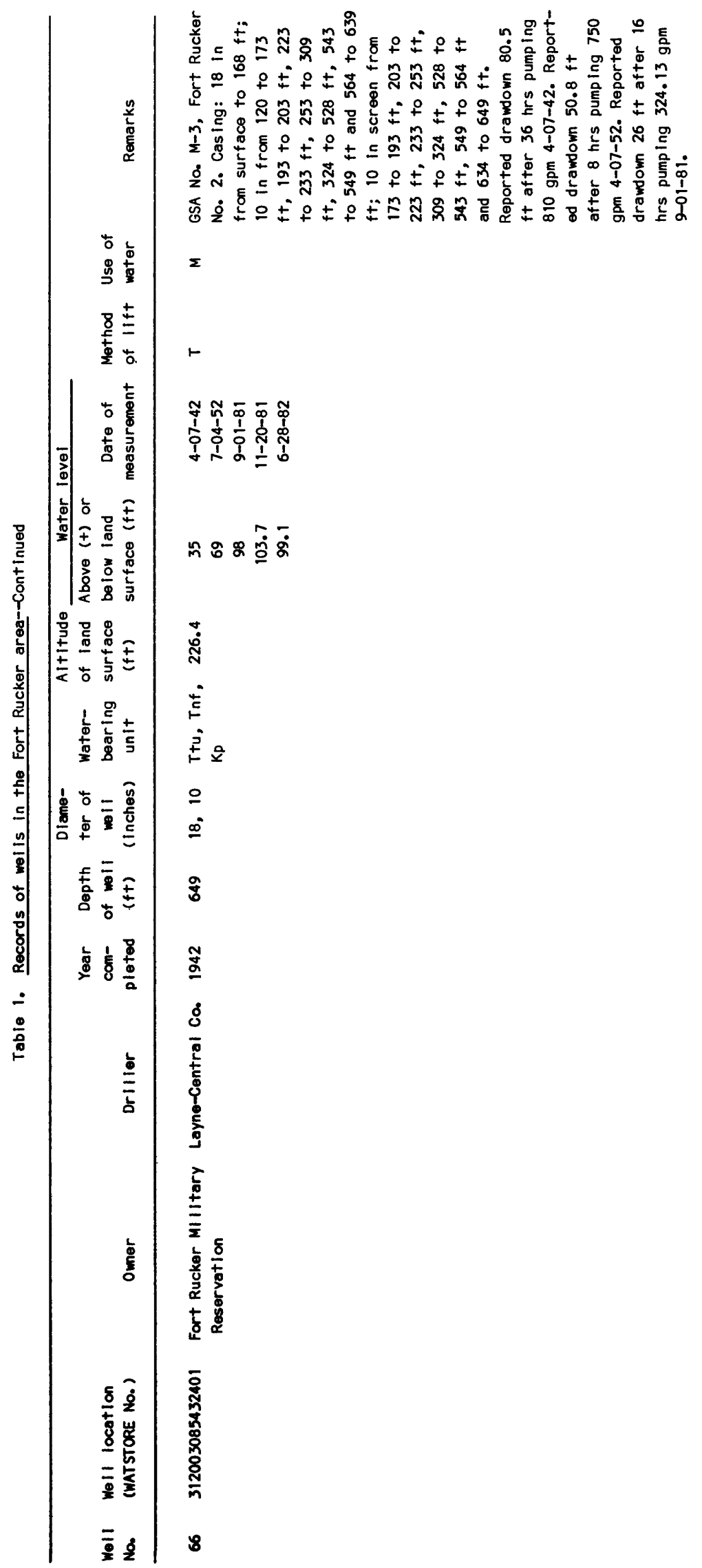




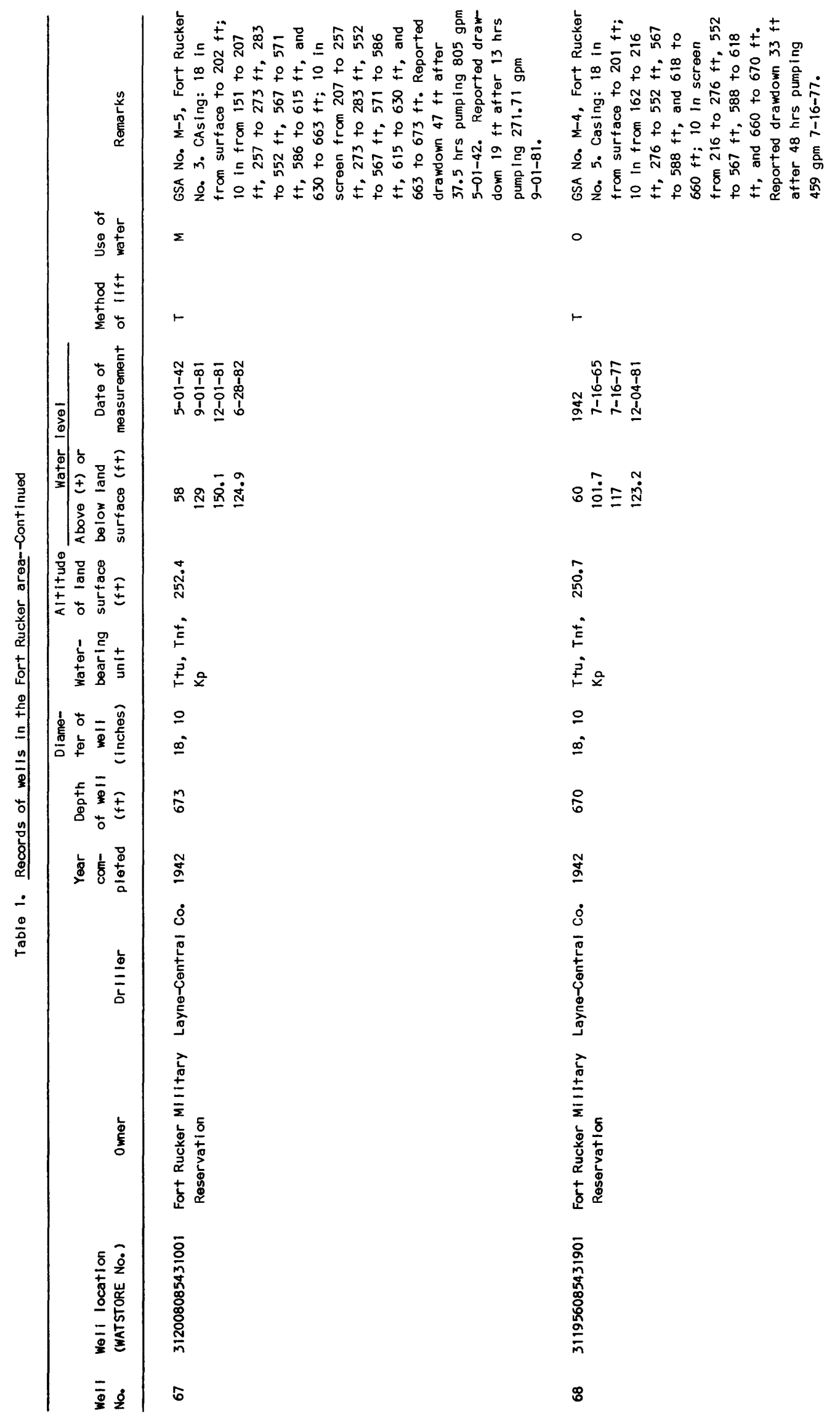




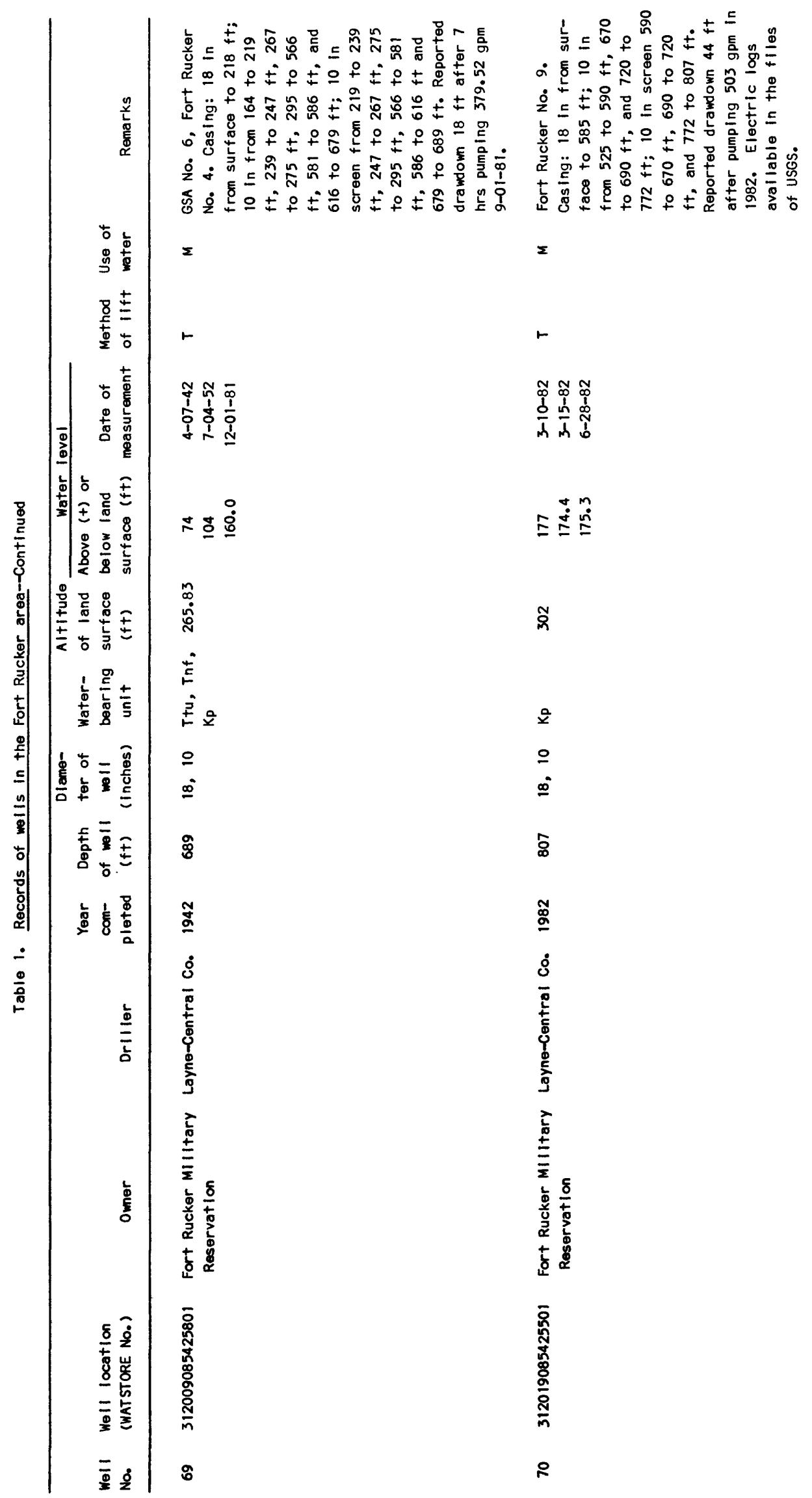




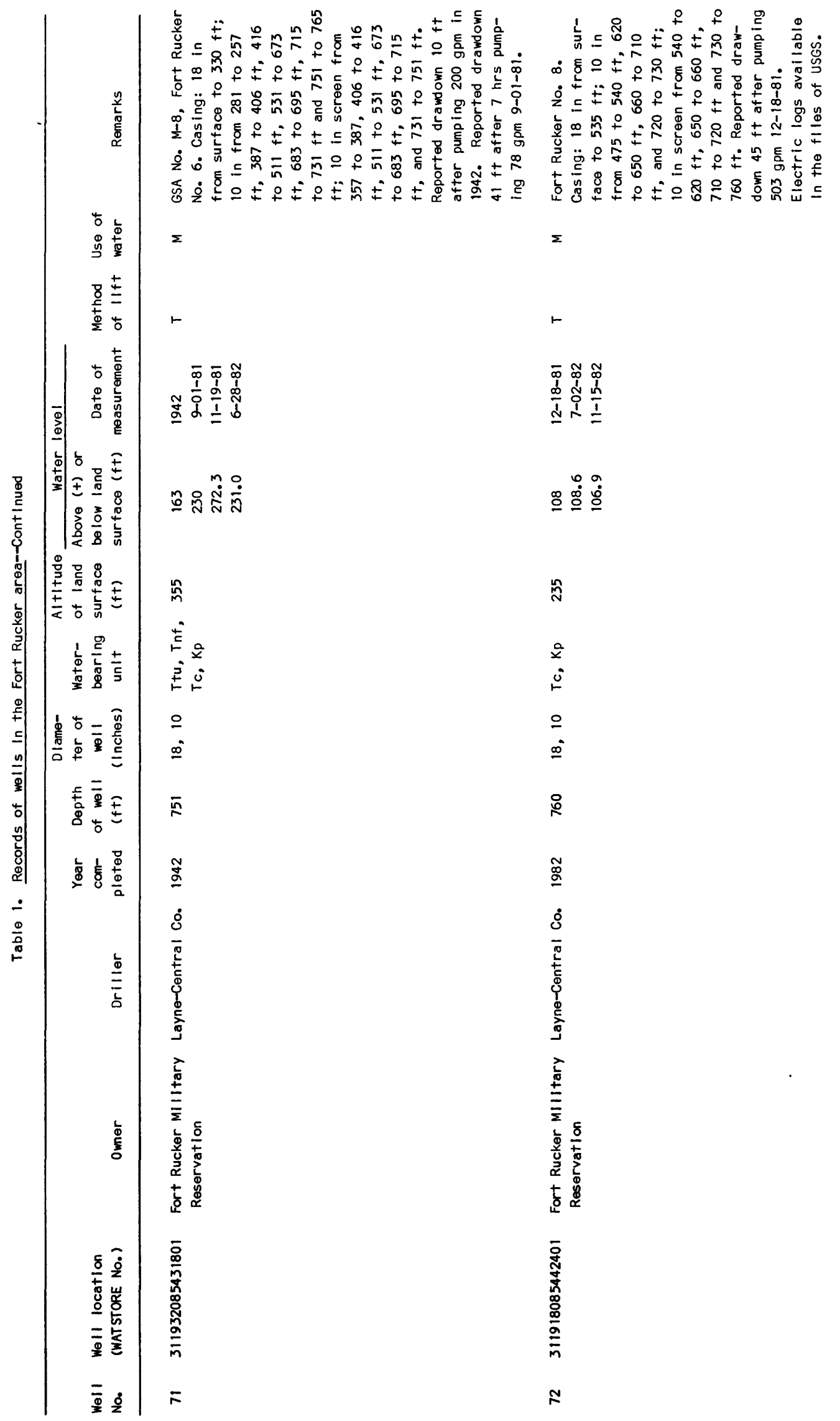




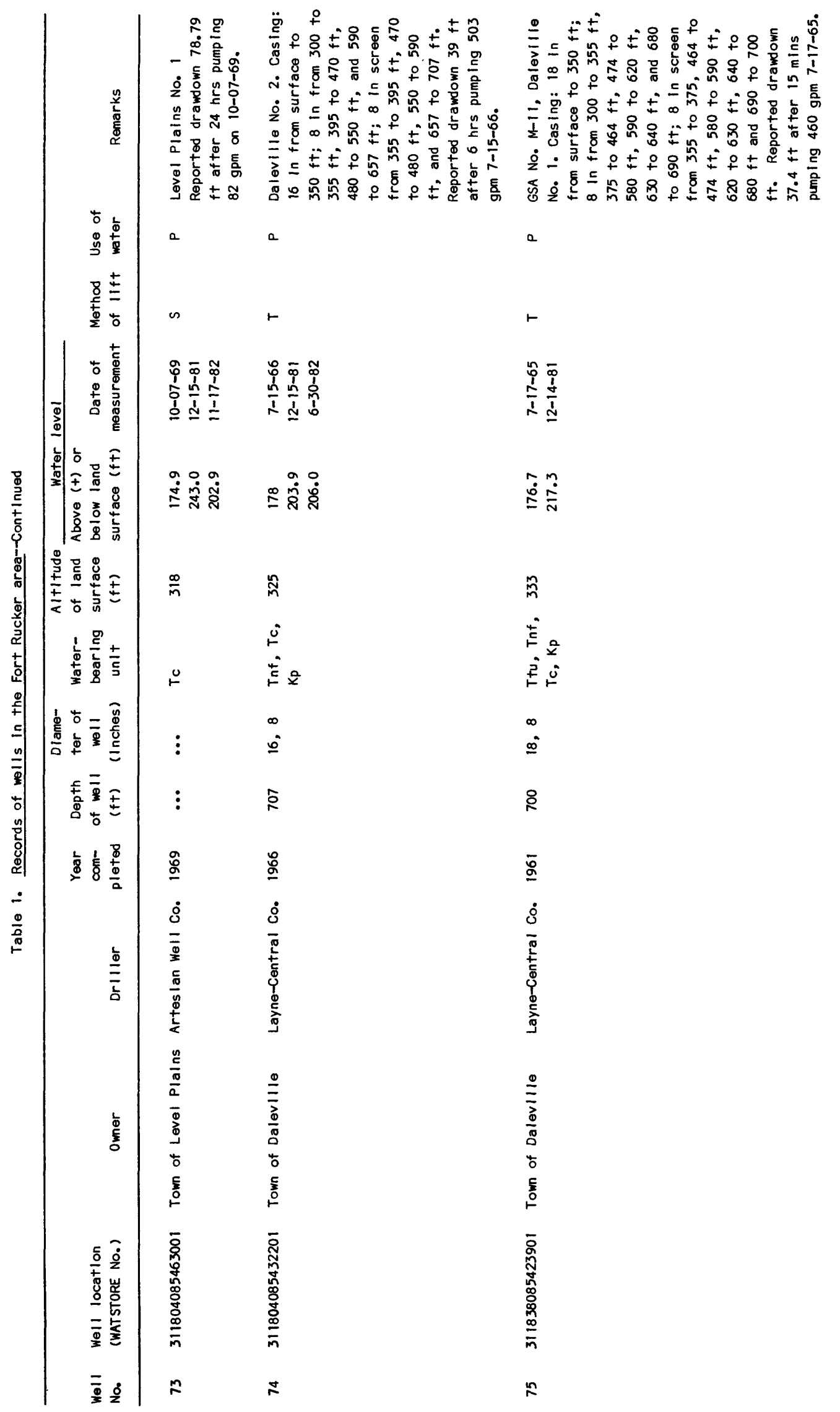




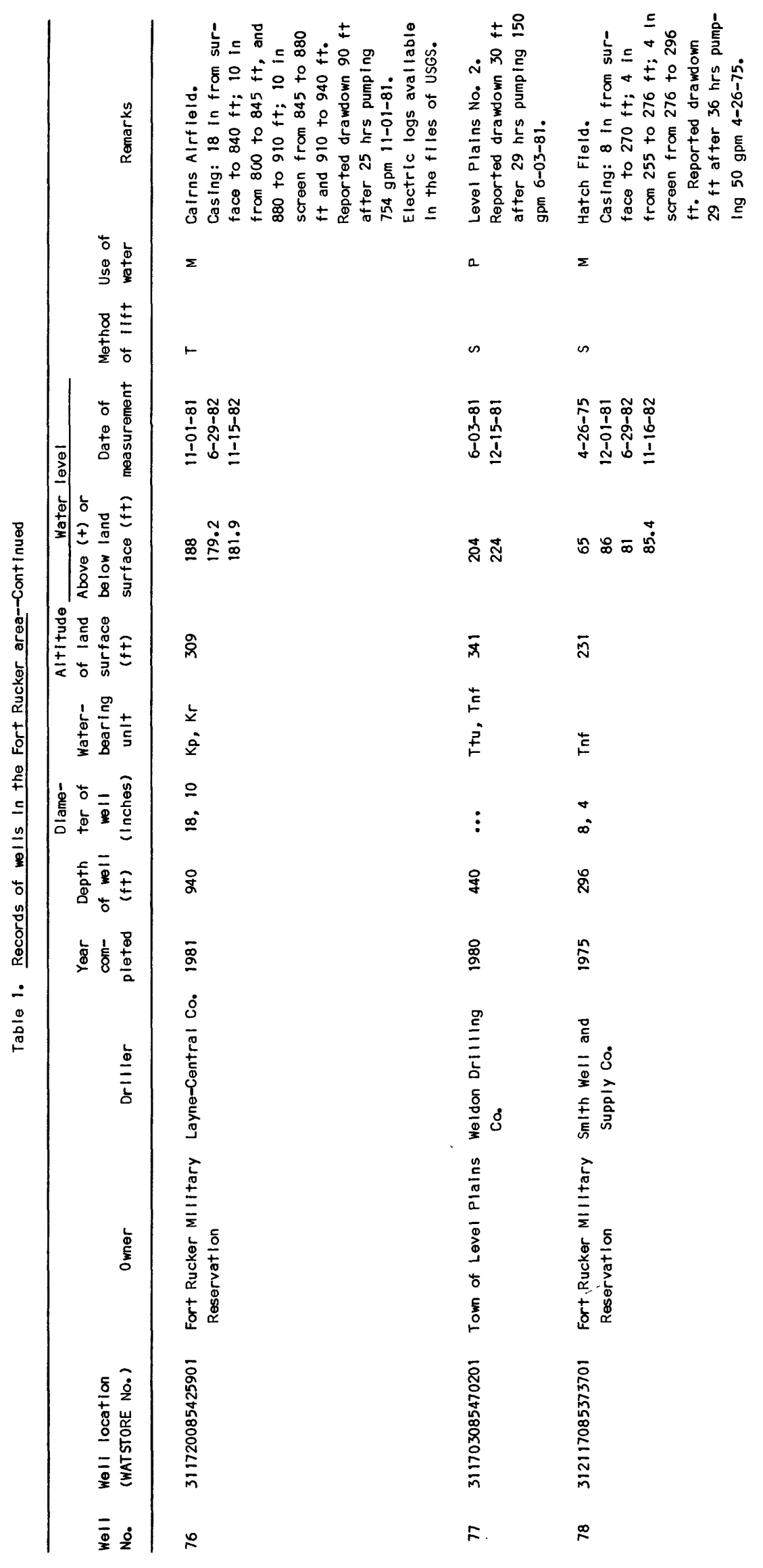




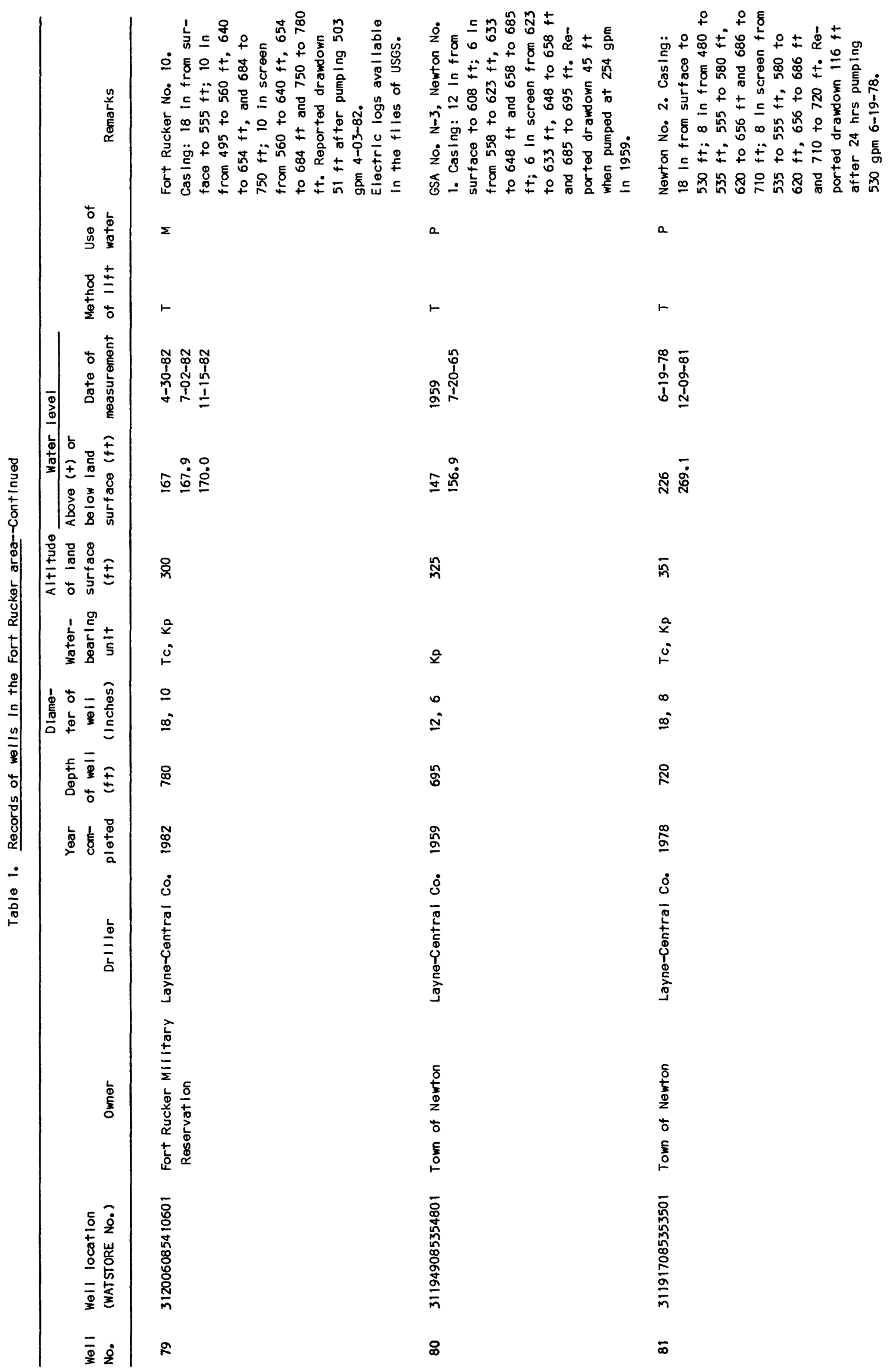




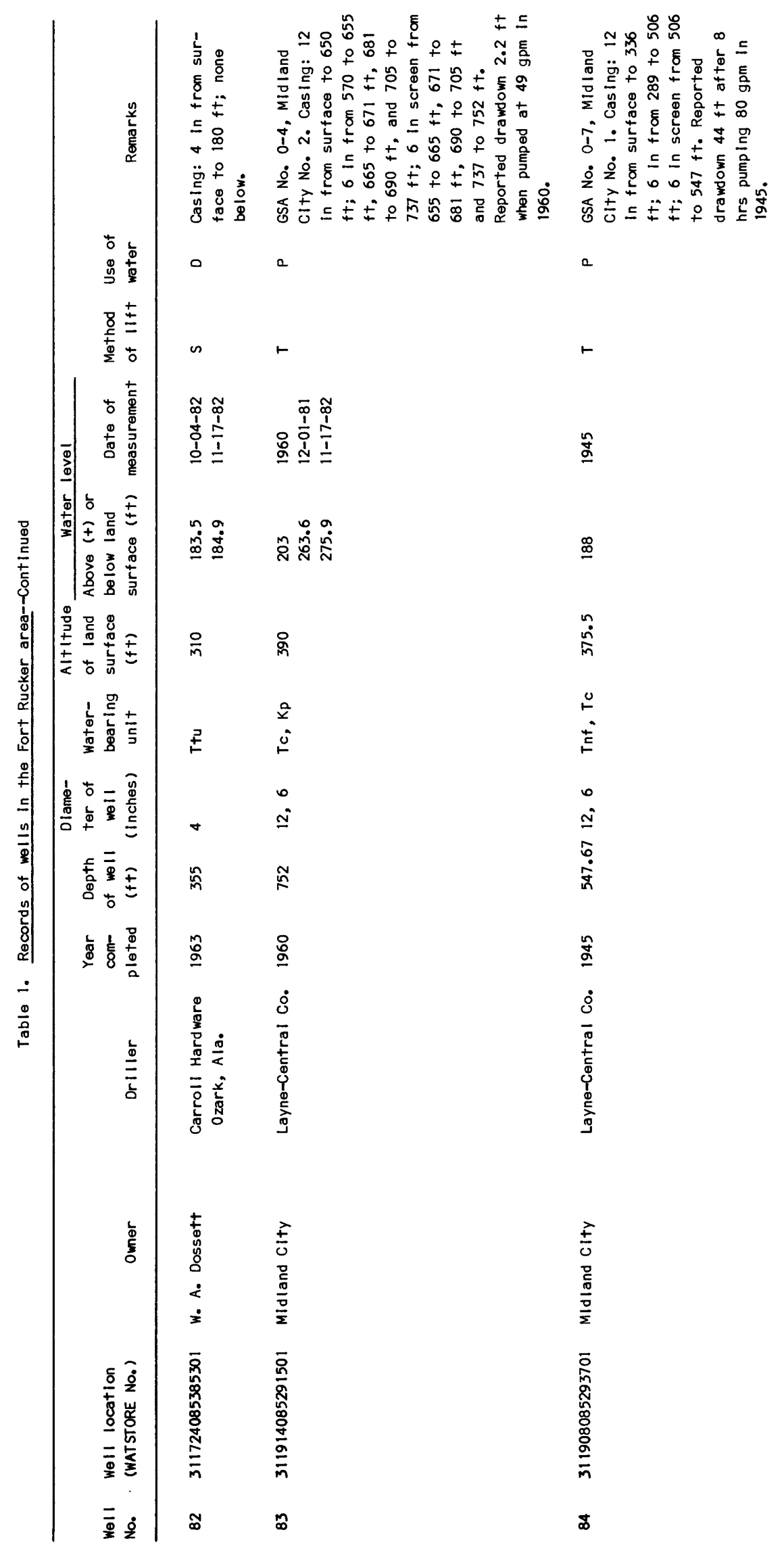




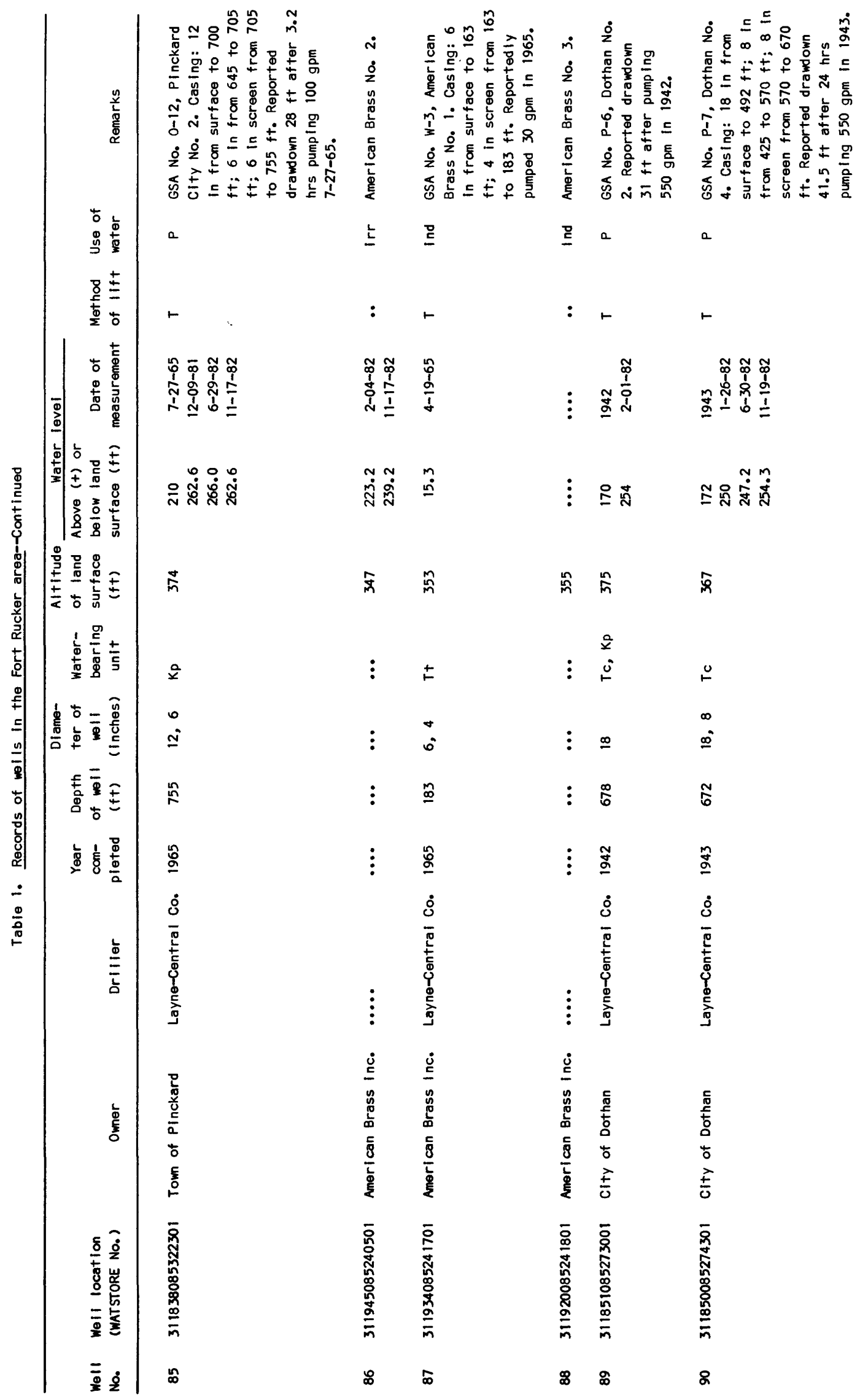




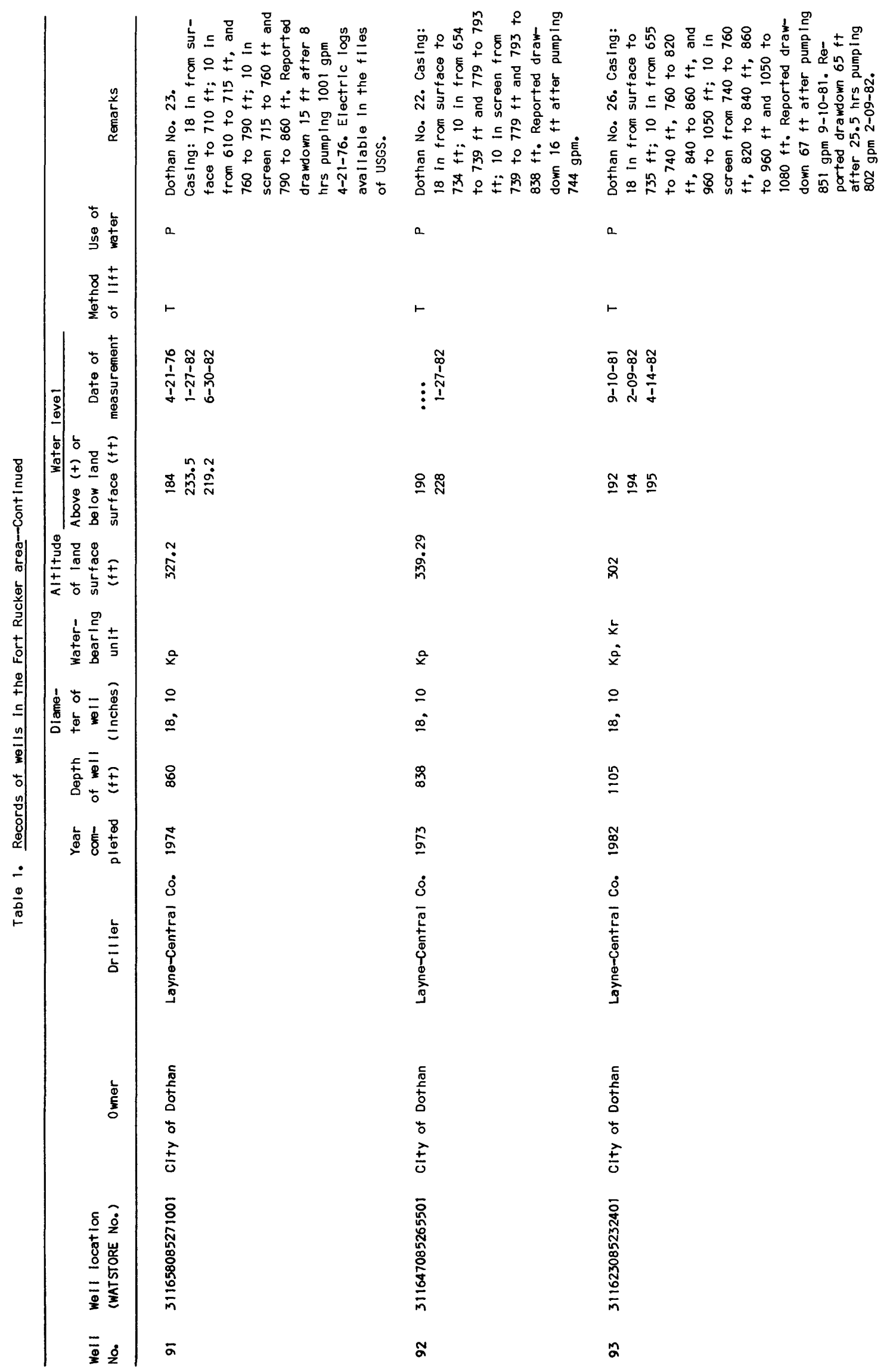




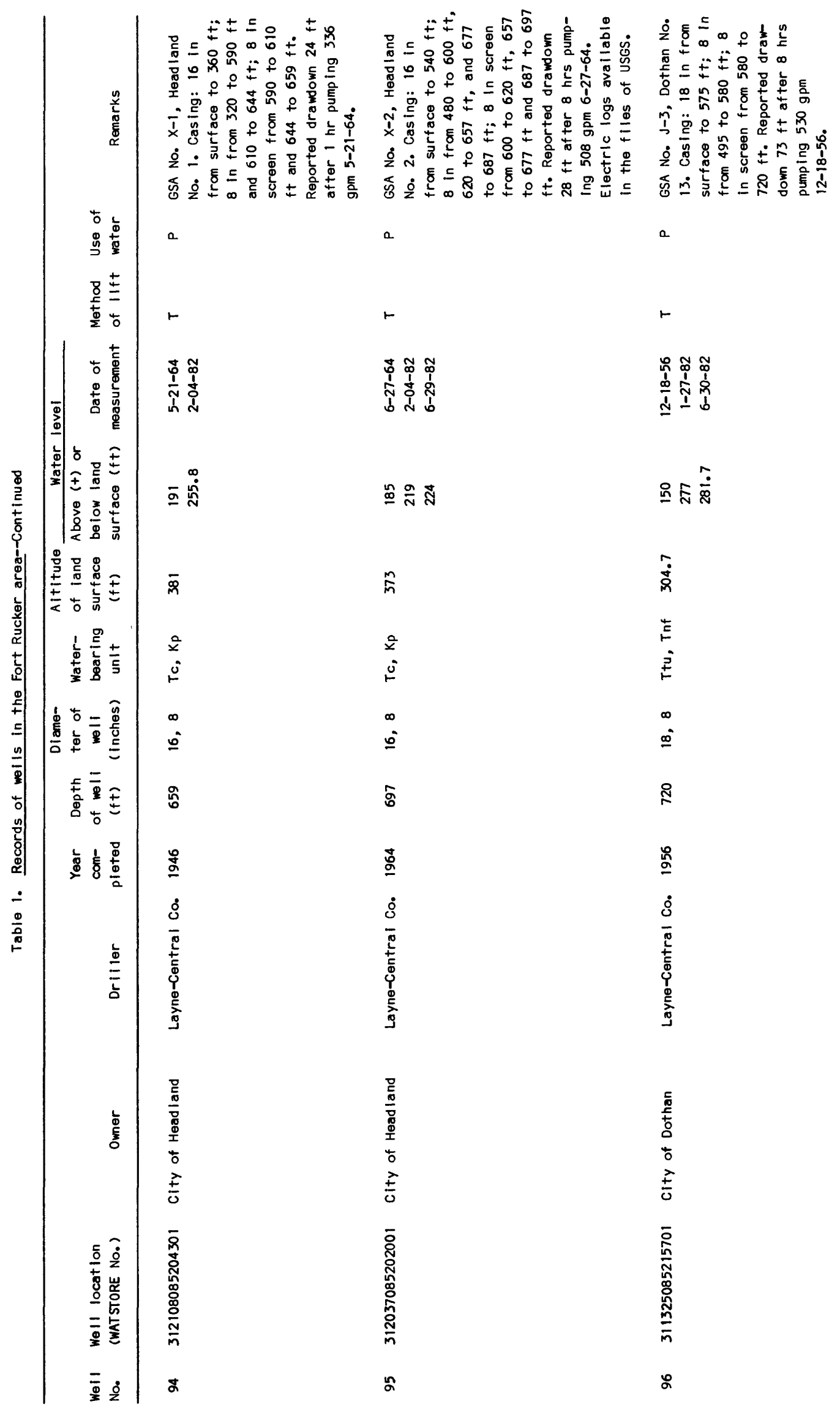




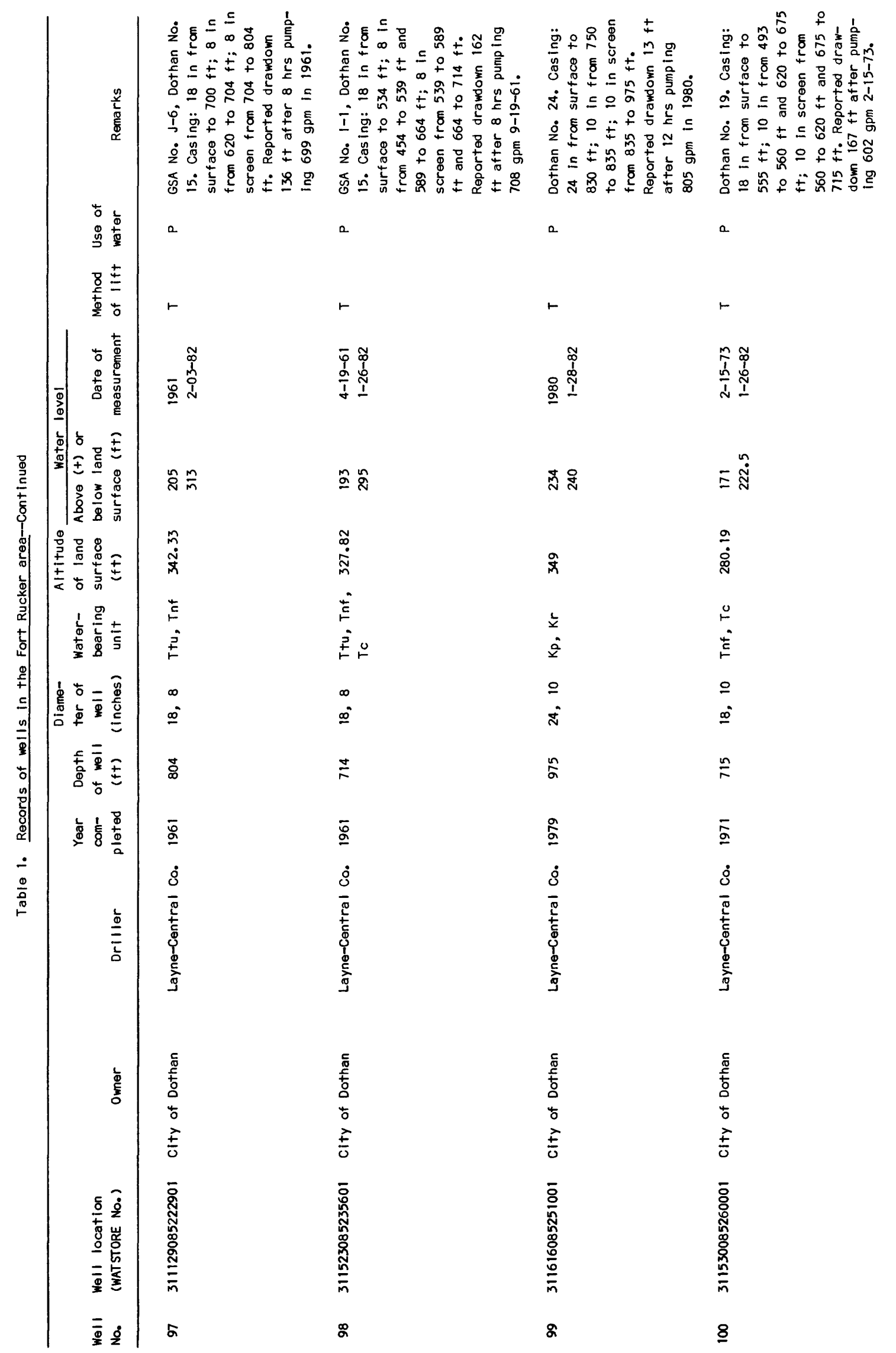




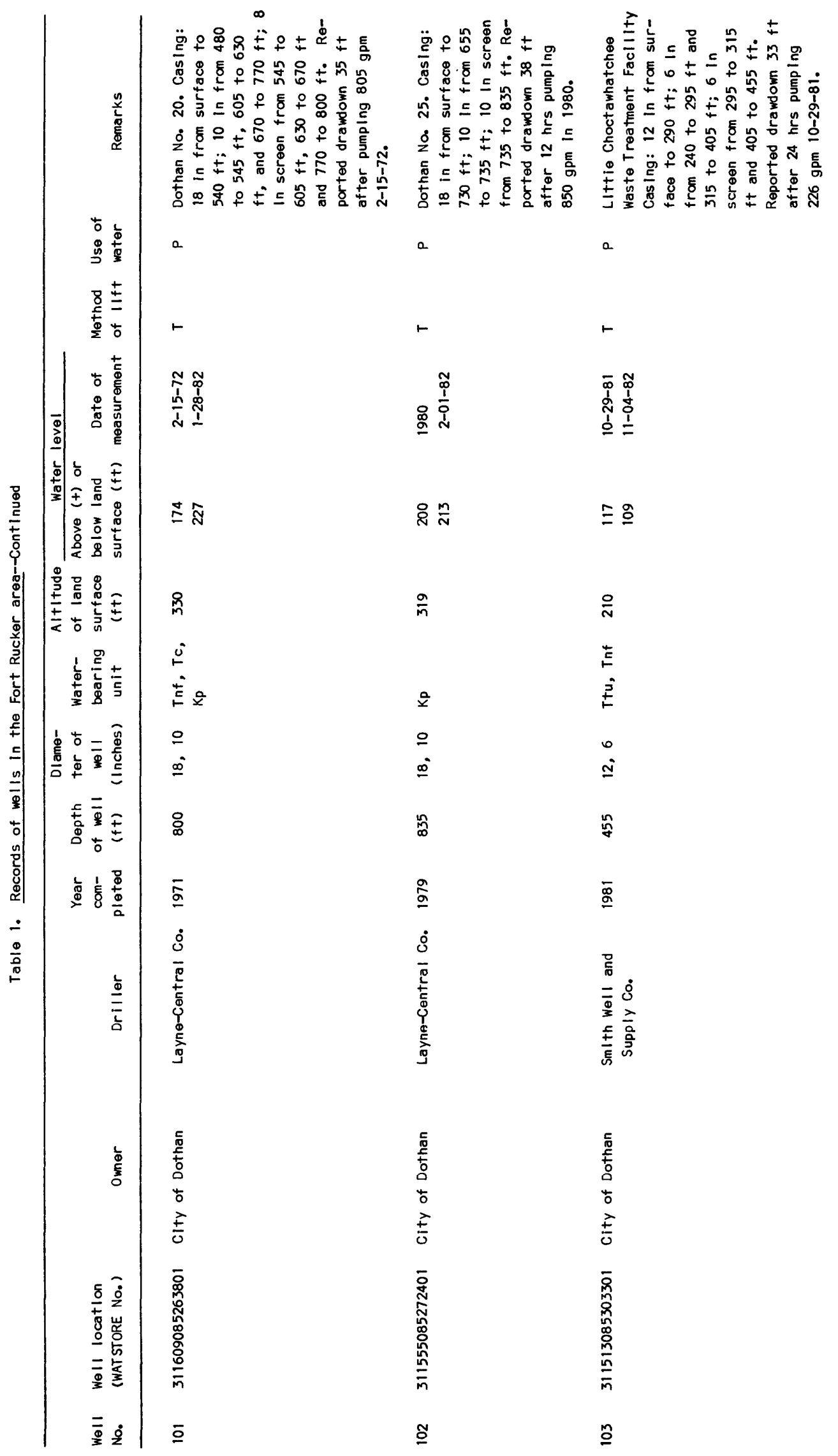




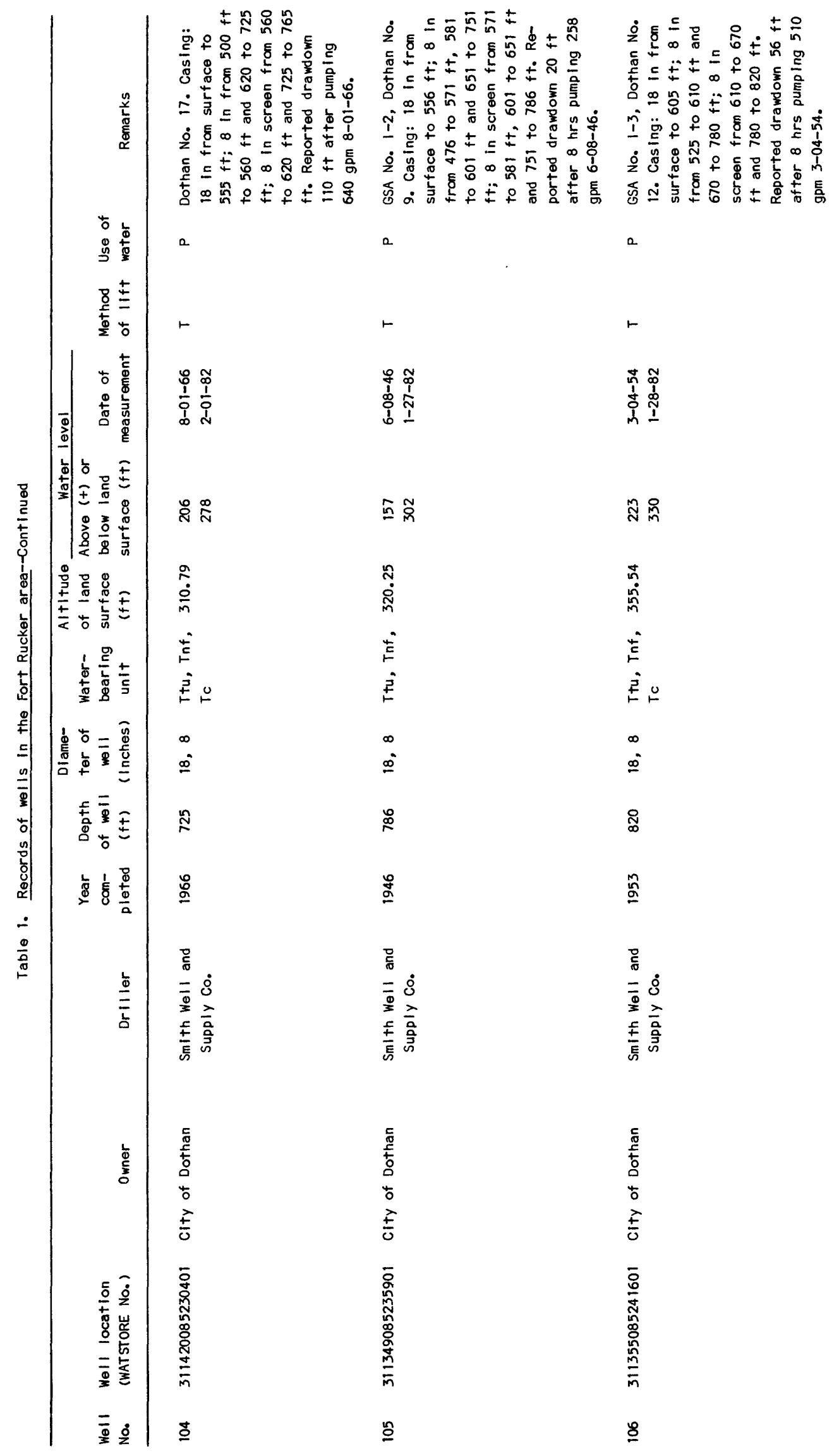




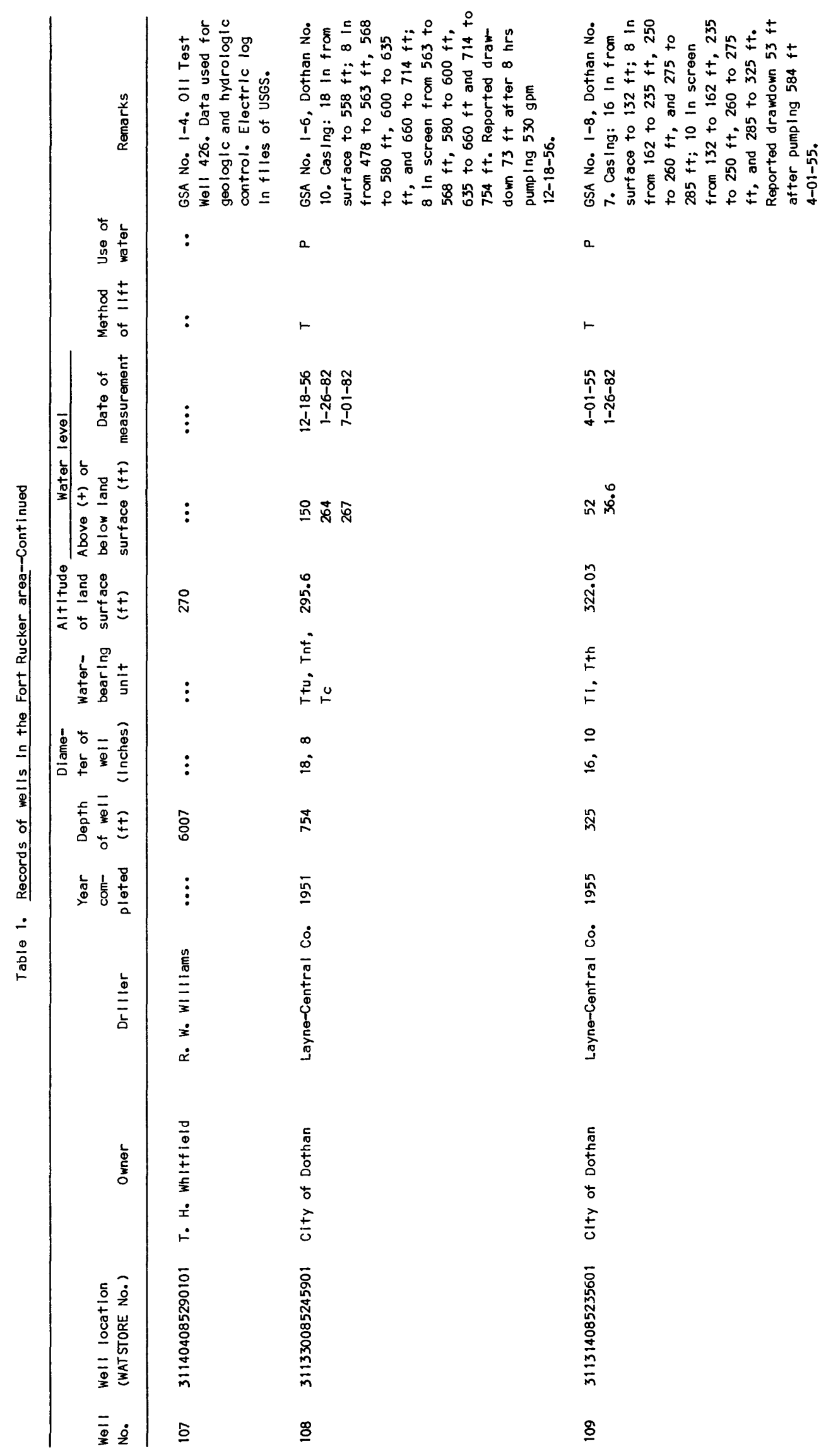




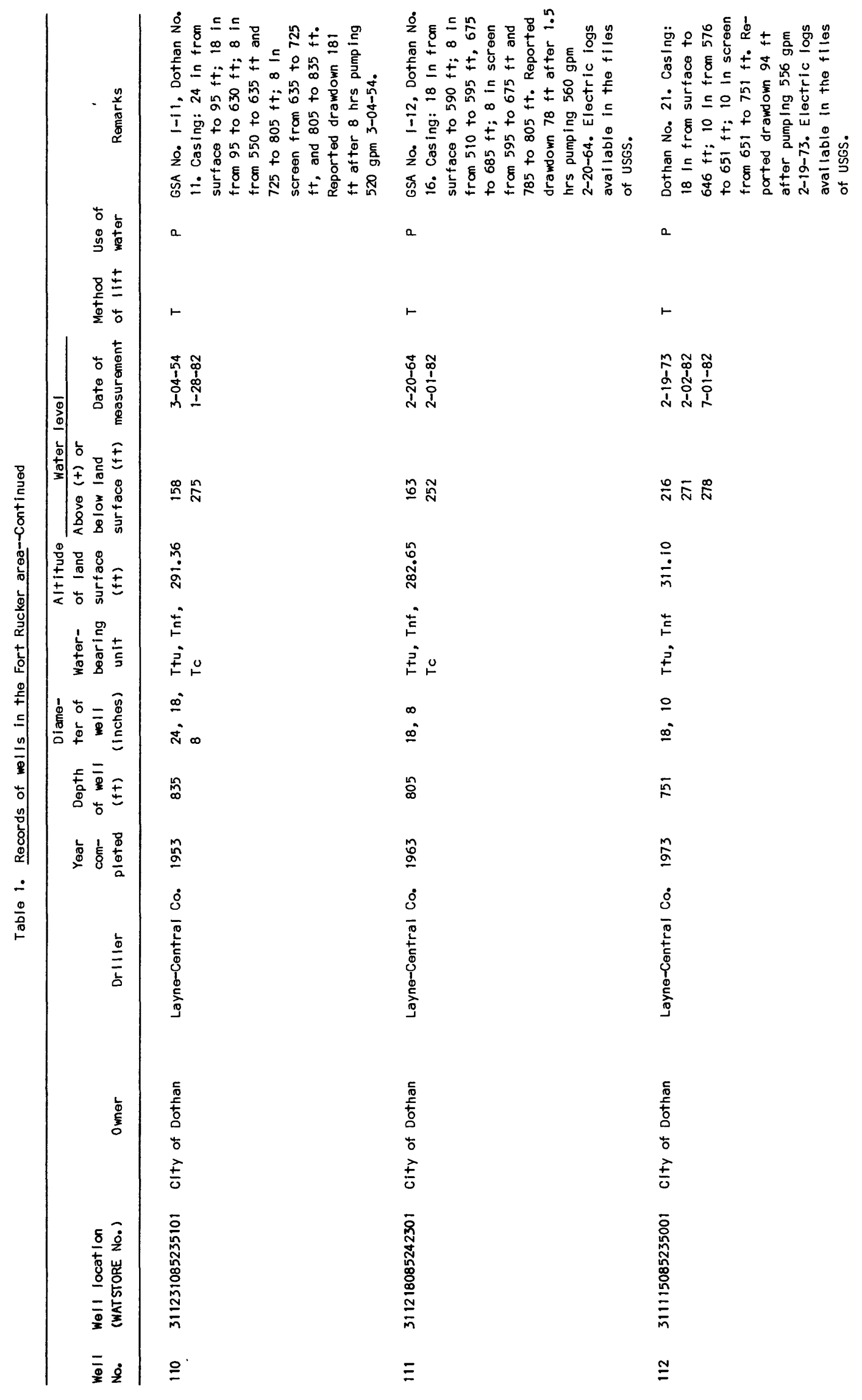




\begin{tabular}{|c|c|c|c|c|c|}
\hline 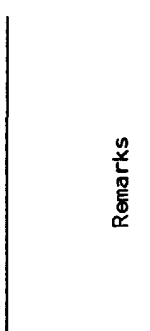 & 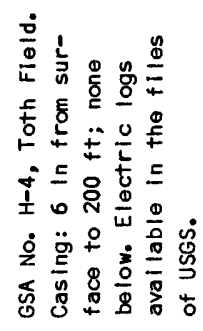 & 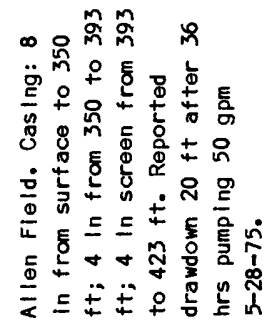 & 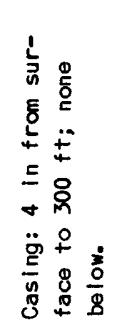 & 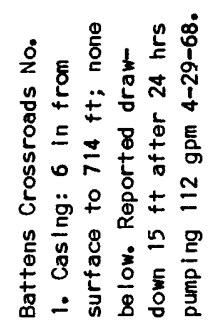 & 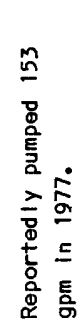 \\
\hline 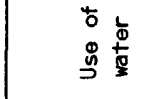 & $\Sigma$ & $\Sigma$ & 0 & a & $\underline{t}$ \\
\hline 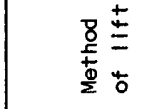 & in & $\infty$ & is & en & s \\
\hline 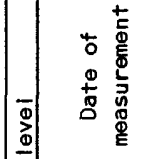 & 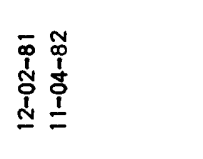 & 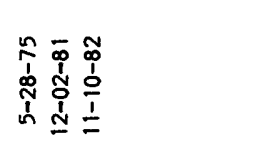 & 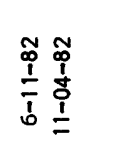 & 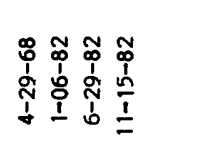 & 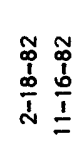 \\
\hline 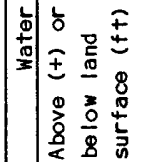 & वें & 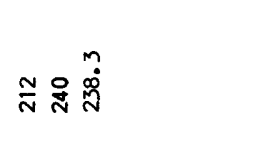 & 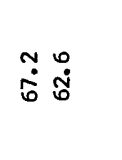 & m & $\begin{array}{l}\dot{0} \\
\stackrel{0}{0} \\
\stackrel{0}{0}\end{array}$ \\
\hline 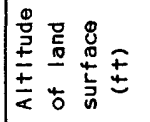 & $\frac{a}{m}$ & 임 & $\stackrel{\infty}{\sim}$ & 怘 & 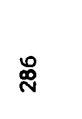 \\
\hline$\frac{1}{6} \pm$ & $\underset{t}{z}$ & & ${ }_{E}^{E}$ & & \\
\hline 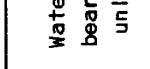 & \pm & $\stackrel{2}{\underline{1}}$ & $\underset{\dot{1}}{\dot{1}}$ & $\stackrel{0}{\vdash}$ & $\stackrel{0}{\llcorner}$ \\
\hline 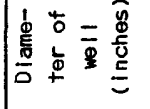 & 0 & $\dot{\infty}$ & $\sigma$ & 0 & 。 \\
\hline 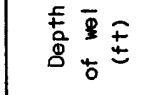 & $\begin{array}{l}\infty \\
\& \\
q\end{array}$ & $\stackrel{\dddot{Z}}{ }$ & 卓 & $\frac{N}{\infty}$ & ถ్రి \\
\hline 兽点离 & $\vdots$ & 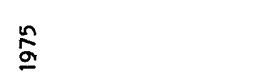 & 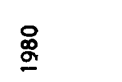 & $\stackrel{\text { 。 }}{\stackrel{\circ}{2}}$ & $\stackrel{5}{\underline{I}}$ \\
\hline$\frac{\grave{\Phi}}{\overline{\bar{L}}}$ & 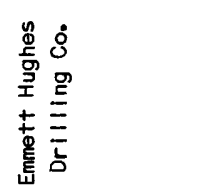 & 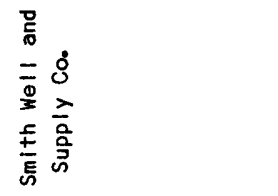 & 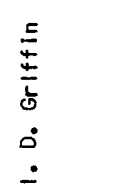 & $\begin{array}{l}\frac{5}{5} \\
\overline{\frac{5}{5}} \\
\text { के } \\
\text { o }\end{array}$ & 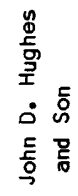 \\
\hline 产 & 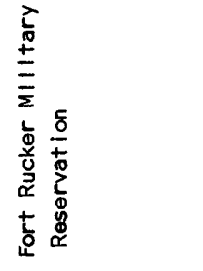 & 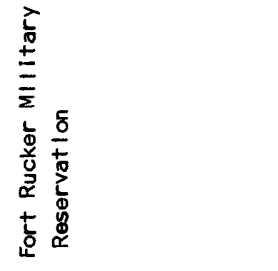 & $\begin{array}{l}8 \\
\frac{0}{0} \\
0 \\
8 \\
8 \\
\frac{0}{7} \\
\frac{0}{x}\end{array}$ & 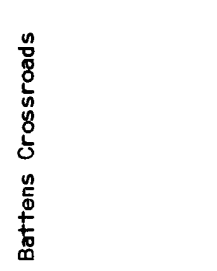 & 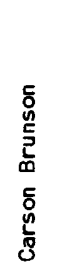 \\
\hline 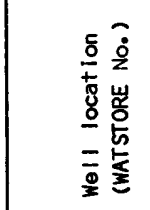 & 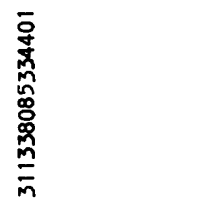 & 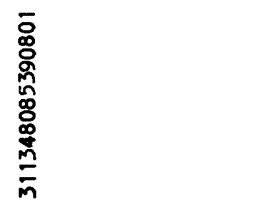 & 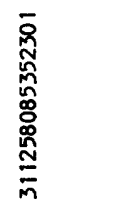 & 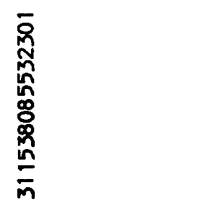 & 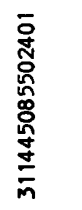 \\
\hline$\overline{\overline{0}} \dot{q}$ & $\stackrel{m}{=}$ & $\Xi$ & $\cong$ & $\cong$ & $\Xi$ \\
\hline
\end{tabular}




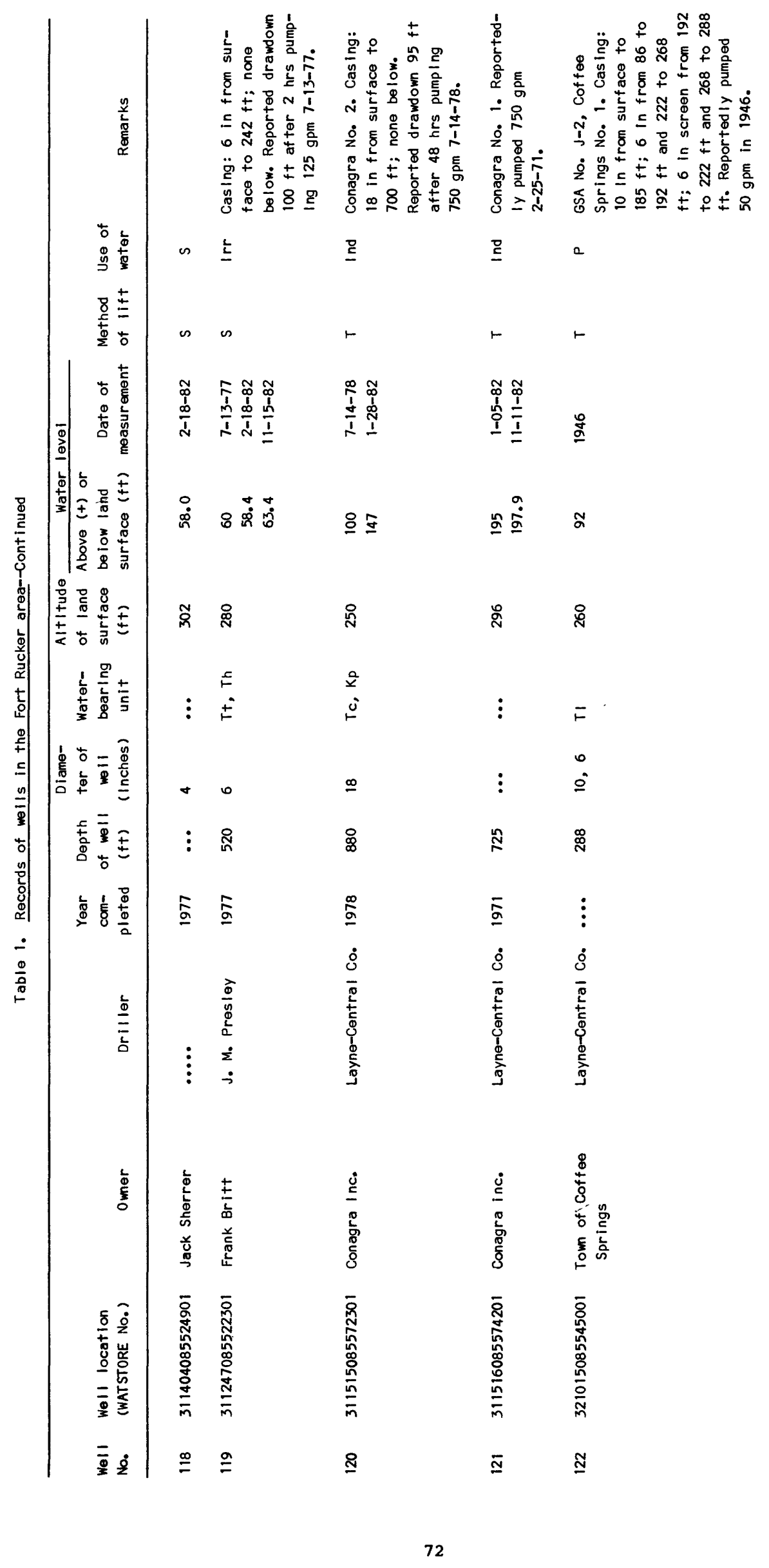




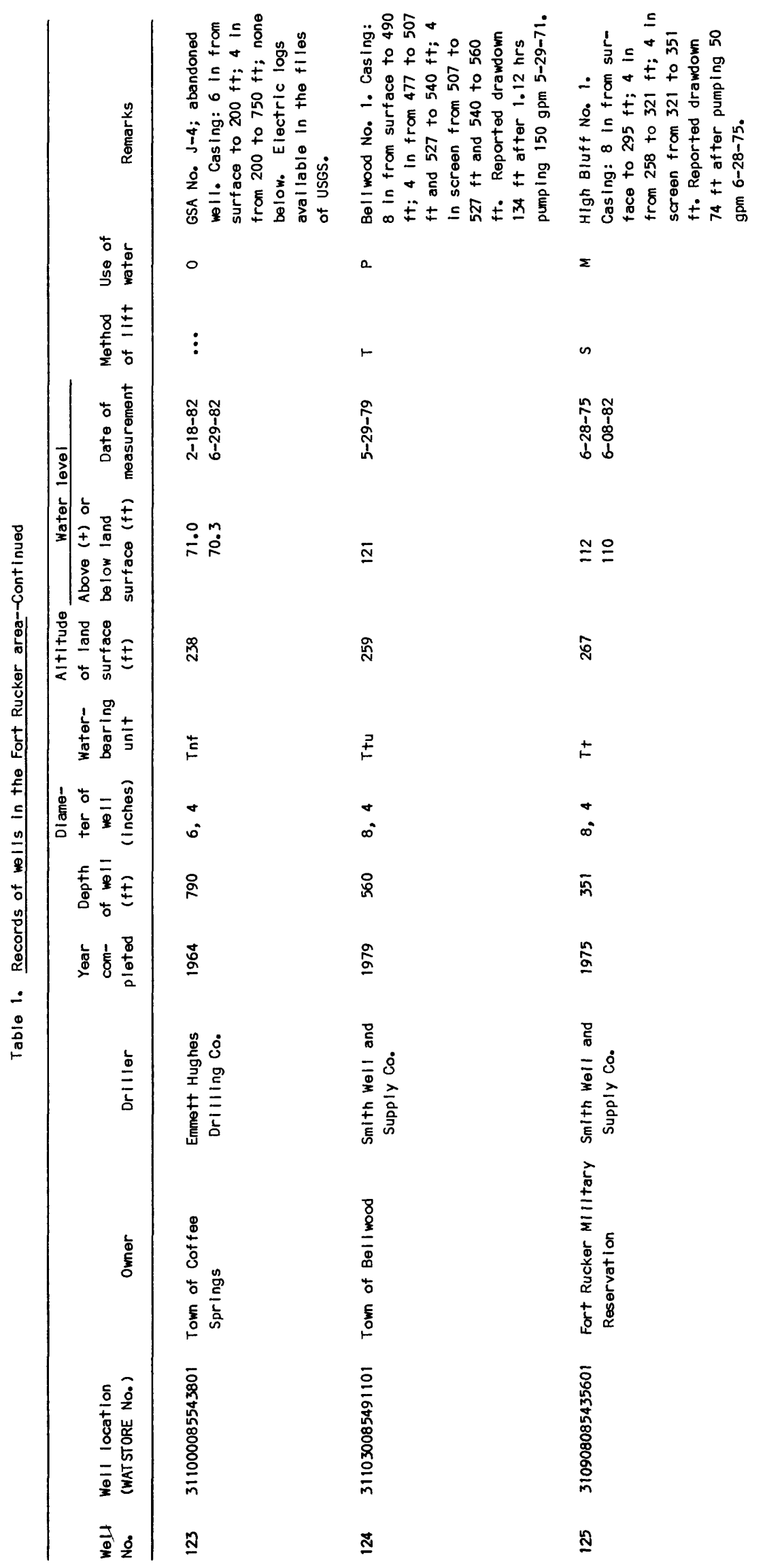




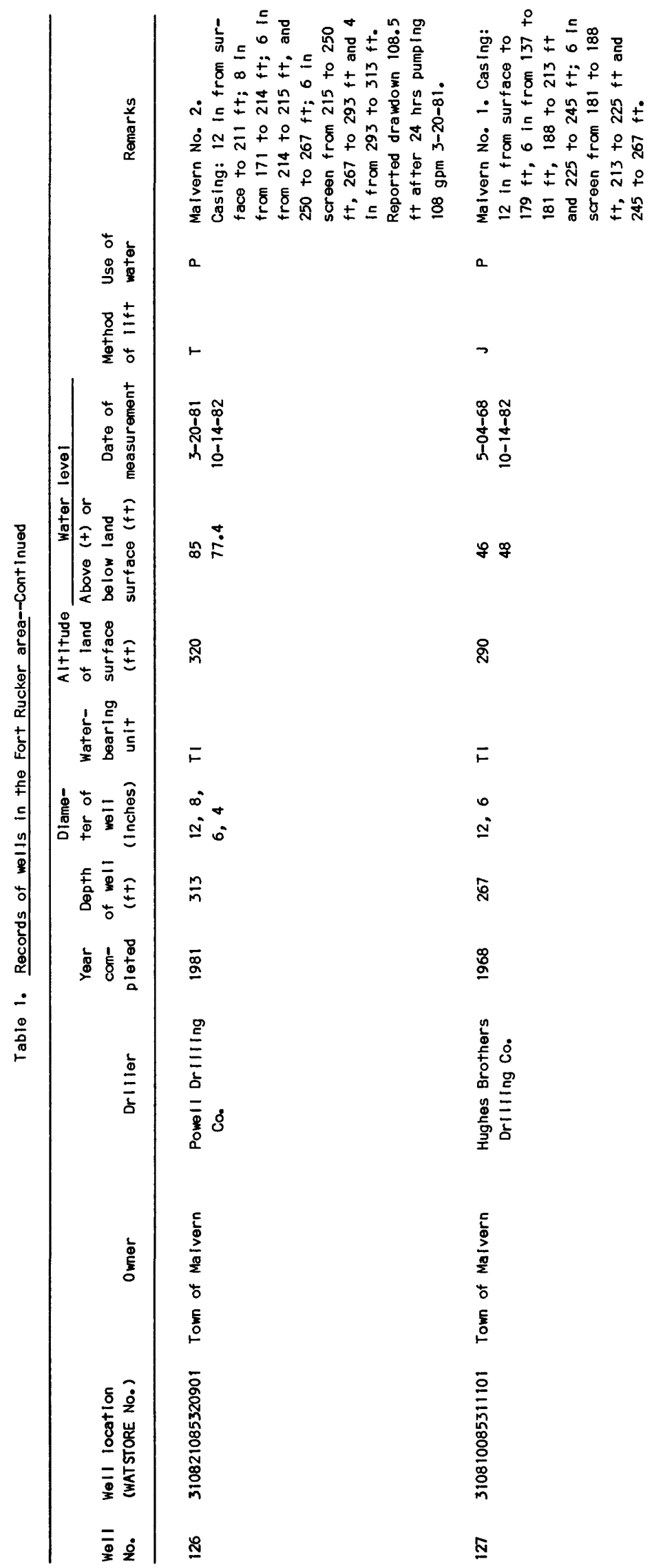


Table 2.--Sample logs of wells in the Fort Rucker area

We11 10

$\begin{array}{ll}\text { Owner: Town of Ariton - Well } 1 & \text { Driller: Gray Artesian Well Co. } \\ \text { Samples described by Randall Fleming, Geological Survey of Alabama }\end{array}$

Samples described by Randall Fleming, Geological Survey of Alabama

(ft)

$(\mathrm{ft})$

Tuscahoma Sand

Sand, clear to grayish-orange, very fine to medium, subangular to subrounded, quartzose, glauconitic.

Sand, clear to grayish-orange, very fine to medium, with the finer fractions in abundance, subangular to subrounded, quartzose, glauconitic.

Sample missing.

Sand, grayish-orange, very fine to fine, subangular, quartzose, slightly glauconitic; clay, light gray, silty, micaceous, carbonaceous.

Sand, yellowish-gray, very fine to fine, subangular, quartzose, trace mica.

Sample missing.

1060

Sand, clear to moderate pink, fine to medium, subangular to subrounded, quartzose, trace mica.

Sand, clear to moderate pink, fine to medium, subangular to subrounded, quartzose, trace mica.

Sand, clear to moderate pink, fine to coarse, subangular to subrounded, quartzose, trace mica.

Sand, light gray, coarse to very coarse, subrounded, quartzose; clay, light gray, silty micaceous, carbonaceous; limonitic ironstone, moderate red, sandy, clayey.

Sand, yellowish-gray, fine to coarse, subangular to subrounded, quartzose; clay, same; limonitic ironstone, pale orange, sandy.

Sand, light gray to grayish-yellow-green, fine to very coarse, angular to subrounded, glauconitic, grains with clay coating in part.

Sand, light gray to grayish-yellow-green, fine to very coarse, subangular to subrounded, quartzose, glauconitic, clay coatings on some grains.

Nanafalia Formation

Sand, light gray, very fine to coarse, subangular to subrounded, quartzose; clay, light gray, silty, micaceous, carbonaceous; trace sandstone, white, calcareous; shell fragments present.

Sand, light gray, very fine to medium, subangular to subrounded, quartzose, trace glauconitic; clay same; shell fragments and few micro fossils.

Sand, same; clay, light gray to medium light gray, silty, micaceous, calcareous; claystone, light gray, sandy glauconitic, calcareous; shell fragments and micro fossils present. 
Table 2.--Sample logs of wells in the Fort Rucker area--Continued

Wel1 10

Thickness Depth

(ft)

(ft)

Nanafalia Formation (continued)

Sample missing.

Sand, light gray, very fine to medium, subangular to subrounded, quartzose, slightly glauconitic; clay, same; shell fragments present.

Sand, light gray, very fine to medium, subangular to subrounded, quartzose, glauconitic, clay, same; shell fragments and micro fossils (Ostracods) present.

Sand light gray, very fine to medium, subangular to subrounded, quartzose; clay, medium gray, silty, micaceous, calcareous; clay, light gray, sandy, micaceous, calcareous; shell fragments present.

Sand, same; clay, light gray, sandy, micaceous, calcareous; clay, medium gray, same.

Sand, light gray, very fine to coarse, subangular to

subrounded, quartzose, glauconitic, fossiliferous; clay, medium gray, silty, micaceous, calcareous; shell

fragments and micro fossils.

Sand, same; marl, light gray, sandy, glauconitic, porous; clay, same; micro fossils and shell fragments present; Ostrea thirsae.

Sand, light gray, very fine to medium, angular to subrounded, quartzose, glauconitic; clay, medium gray, silty, micaceous, calcareous.

Clayton Formation - Contact between 250-270

Sand, yellowish-gray, very fine to coarse, subangular to subrounded, quartzose, glauconitic, fossiliferous; limestone, light gray, crystalline, fossiliferous, glauconitic in part; shell fragments and micro fossils.

Limestone, light gray, glauconitic, sandy, fossiliferous; sand, same.

Sample missing.

Sand, yellowish-gray, very fine to fine, subangular, quartzose, glauconitic; limestone, same.

Sand, yellowish-gray, very fine to fine, subangular, quartzose, glauconitic, fossiliferous; limestone, same in slightly increasing amounts; micro fossils and shell fragments present.

Sand, light gray, fine to coarse, subangular to subrounded, quartz, glauconitic, fossiliferous; limestone, same.

Sand, same; limestone, light gray, fossiliferous, sandy, glauconitic in part; shell fragments and micro fossils present. 
Table 2.--Sample logs of wells in the Fort Rucker area--Continued

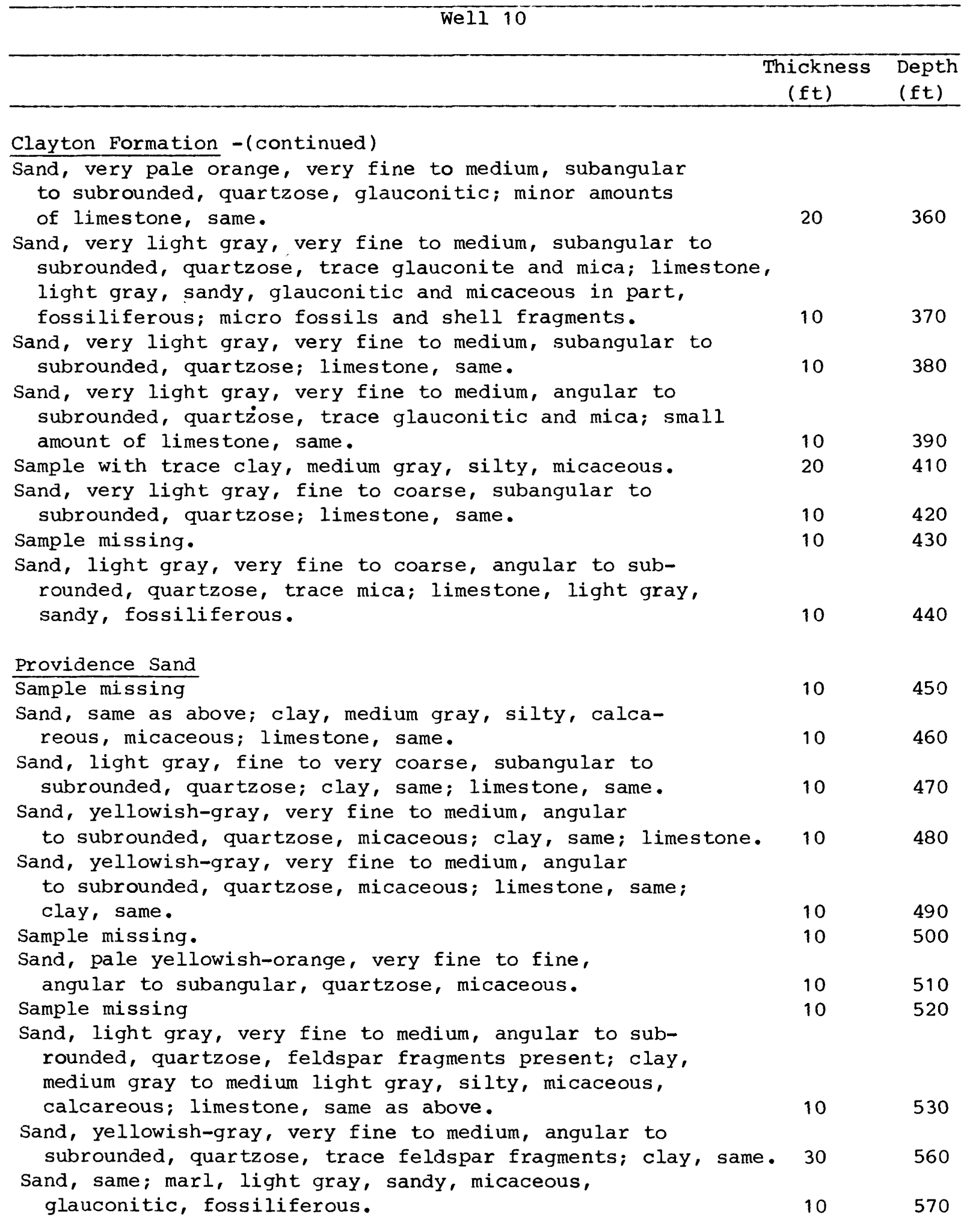


Table 2.--Sample logs of wells in the Fort Rucker area--Continued

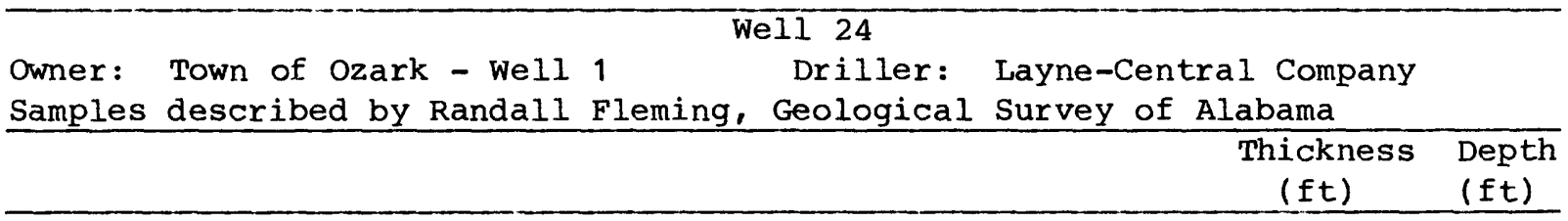

Lisbon Formation

Sand, moderate reddish-brown, very fine to coarse, angular

to subrounded, quartzose, some grains with red clay

coatings, fine grains in excess.

Sand, moderate reddish-orange, very fine to coarse, angular

to subrounded, quartzose, grains with red clay coating,

fine grains in excess.

Sand, moderate reddish-orange very fine to coarse, angular

to rounded, quartzose, grains with red clay coating, fine grains in excess.

Sand, grayish-pink, very fine to coarse, angular to subrounded, quartzose, slight frosting, fine grains in

excess; clay varicolored (orange to pink), silty to sandy. 10

Tallahatta Formation

Sand, very pale orange, fine to coarse, subangular to rounded, quartzose, slight frosting in part, medium grains in excess.

Sand, very pale orange, fine to coarse, subangular to subrounded, quartzose, slight frosting in part, medium grains in excess.

Sand, very light gray, medium to very coarse, subangular to subrounded, quartzose, slight frosting, medium grains in excess.

Sand, very light gray, medium to very coarse, subangular to rounded, quartzose, slightly frosted, few grains in fine pebble size.

Sand, very light gray, medium to very coarse, subangular to rounded, quartzose, slightly frosted, few grains in pebble size.

Hatchetigbee Formation

Clay, medium gray, silty, micaceous, carbonaceous; sand, very light gray, very fine to coarse, angular to subrounded, quartzose, trace glauconite; shell fragments present.

Clay, medium gray, silty, micaceous, carbonaceous; sand, same. 10 90

Clay, medium gray, silty, micaceous, carbonaceous.

Bashi Marl Member (of some authors)

Marl, light olive-gray, glauconitic, sandy, fossiliferous; clay, light gray, silty, micaceous, glauconitic, fossiliferous; clay, light gray, silty, micaceous, glauconitic, fossiliferous; clay, light gray, silty, micaceous, glauconitic, fossiliferous, calcareous; sand, light gray, very fine to medium, angular to subangular, quartzose, extremely glauconitic; abundant shell fragments present. 
Table 2.--Sample logs of wells in the Fort Rucker area--Continued

Well 24

Thickness Depth

(ft)

Tuscahoma Sand

Sand, yellowish-gray, very fine to coarse, subangular to subrounded, quartzose; marl, same; abundant shell fragments, badly weathered.

8

Sand, yellowish-gray, very fine to coarse, subangular to subrounded, quartzose; marl, same; abundant shell fragments, badly weathered.

Sand, light gray, very fine grained to coarse, angular to subrounded, quartzose, glauconitic, very fine grains in excess; clay, light olive-gray, silty, micaceous, carbonaceous.

Sand, very light gray, very fine to fine, angular, quartzose, glauconitic, micaceous; clay, light gray, silty, micaceous, carbonaceous; trace marl, same.

Sand, yellowish-gray, very fine to medium, angular to subrounded, slightly glauconitic, some grains frosted; clay, medium light gray, silty, micaceous, carbonaceous.

Clay, medium light gray, sandy to silty, micaceous, carbonaceous; sand, same.

Clay, medium light gray, sandy, micaceous, carbonaceous.

Sand, light gray, very fine to medium, angular to subrounded, quartzose, glauconitic (large-grained and a pale yellowgreen color); clay, same.

Sand, light gray to moderate greenish-yellow, fine to coarse, subangular to rounded, quartzose, glauconitic; clay, same.

Sand, light gray to light greenish-gray, medium to coarse, subangular to subrounded, quartzose, glauconitic.

Nanafalia Formation

Sand, same; marl, light gray, sandy, glauconitic; clay, medium light gray, silty, micaceous, carbonaceous.

Sand, pale yellowish-orange, fine to very coarse, subangular to rounded, quartzose, glauconitic; shell fragments present.

Sand, light gray to light greenish-gray, fine to medium, subangular to subrounded, quartzose, glauconitic, frosted in part.

No samples taken.

Sand, yellowish-gray, very fine to medium, subangular to subrounded, quartzose, glauconitic, micaceous, fossiliferous; Robulus sp.?

Sand, light gray to light greenish-gray, fine to coarse, subangular to subrounded, quartzose, glauconitic, fossiliferous, shell fragments and micro fossils.

Sand, light gray, very fine to medium, subangular, quartzose, glauconitic; marl, light gray, sandy, micaceous, fossiliferous.

clay, medium light gray, silty, micaceous, calcareous; marl, same; sand, same. 
Table 2.--Sample logs of wells in the Fort Rucker area--Continued

\section{We11 24}

Thickness Depth

(ft) (ft)

Nanafalia Formation (continued)

Sand, yellowish-gray, very fine to medium, subangular, quartzose, fossiliferous; clay, same; shell fragments and micro fossils (ostracods).

Sand, same; clay, medium light gray, silty to sandy, micaceous, calcareous.

Sand, yellowish-gray, fine to coarse, subangular to subrounded, quartzose, frosted in part; clay, same.

Clayton Formation

Limestone, very light gray, silty, fossiliferous; sand, light gray, coarse to very coarse, subrounded, quartzose, frosted; clay, same.

Limestone, same; light gray, fine to coarse, subangular to subrounded, quartzose, frosted.

Limestone, very light gray, silty, fossiliferous; sand, yellowish gray, very fine to coarse, subangular to subrounded, quartzose, frosted in part.

Limestone, very light gray, porous, fossiliferous, silty.

Limestone, very light gray, silty, fossiliferous; trace sand. 10

Limestone, same; sand, light gray, medium to coarse, subrounded, quartzose, micaceous, frosted in part.

Limestone, same; sand, light gray, medium to coarse, subangular to subrounded, quartzose, frosted in part.

Providence Sand

Sand, light gray, fine to coarse, subangular to subrounded, quartzose, micaceous, frosted; limestone, same.

Sand, yellowish-gray, fine to coarse, subangular to subrounded, quartzose, frosted; limestone, same.

Sand, light gray, very fine to medium, angular to subrounded, quartzose, slight frosting; trace limestone, same.

No sample.

Sand, very pale orange, very fine to fine, subangular, quartzose, trace feldspar fragments.

Sand, very pale orange, very fine to fine, subangular, quartzose, micaceous, feldspar fragments; trace limestone.

Sand, light gray, very fine to medium, subangular to subrounded, quartzose, micaceous, frosted; limestone, very light gray, micaceous, fossiliferous.

Limestone, very light gray, micaceous, sandy, fossiliferous; sand, same.

Sand, light gray, very fine to medium, angular to subrounded, quartzose, slightly fossiliferous; limestone, same. 
Table 2.--Sample logs of wells in the Fort Rucker area--Continued

Well 24

\begin{tabular}{cc}
$\begin{array}{c}\text { Thickness } \\
\text { (ft) }\end{array}$ & $\begin{array}{l}\text { Depth } \\
(\mathrm{ft})\end{array}$ \\
\hline
\end{tabular}

Providence Sand (continued)

Clay, medium gray, silty, micaceous, calcareous; sand, same.

Sand, light gray, very fine to coarse, subangular to rounded, quartzose, micaceous; clay, same; trace limestone.

Clay, light gray, silty, micaceous, carbonaceous, calcareous; sand, same.

Clay, same; sand, light gray, very fine to coarse, angular to subrounded, quartzose, micaceous.

Limestone, very light gray, sandy, fossiliferous; sand, yellowish-gray, medium to very coarse, subangular to

rounded, quartzose, feldspar fragments.

Ripley Formation

\begin{tabular}{lll}
\hline Sand, light gray to grayish-orange, fine to coarse, sub- & & \\
angular to subrounded, quartzose, feldspar fragments & 20 & 720 \\
present, micaceous; limestone, same. & 10 & 730 \\
No sample. & 20 & 750 \\
Sand, same; limestone, yellowish-gray, sandy, micaceous. & \\
Sand, light gray to pale yellowish-orange, fine to very & \\
$\quad$ coarse, subangular to rounded, quartzose, feldspar frag- & 26 & 776 \\
ments; trace limestone, same. & & \\
Sand, light gray to grayish-orange, fine to coarse, sub- & \\
$\quad$ angular to rounded, quartzose, feldspar fragments present, & 25 & 801 \\
slight micaceous; trace limestone, same. & & \\
Sand, very pale orange, very fine to fine, angular to sub- & 22 & 823 \\
angular, quartzose, micaceous. \\
Sand, very pale orange, very fine to fine, angular to sub- \\
angular, quartzose, micaceous, few ostracods.
\end{tabular}


Table 2.--Sample logs of wells in the Fort Rucker area--Continued

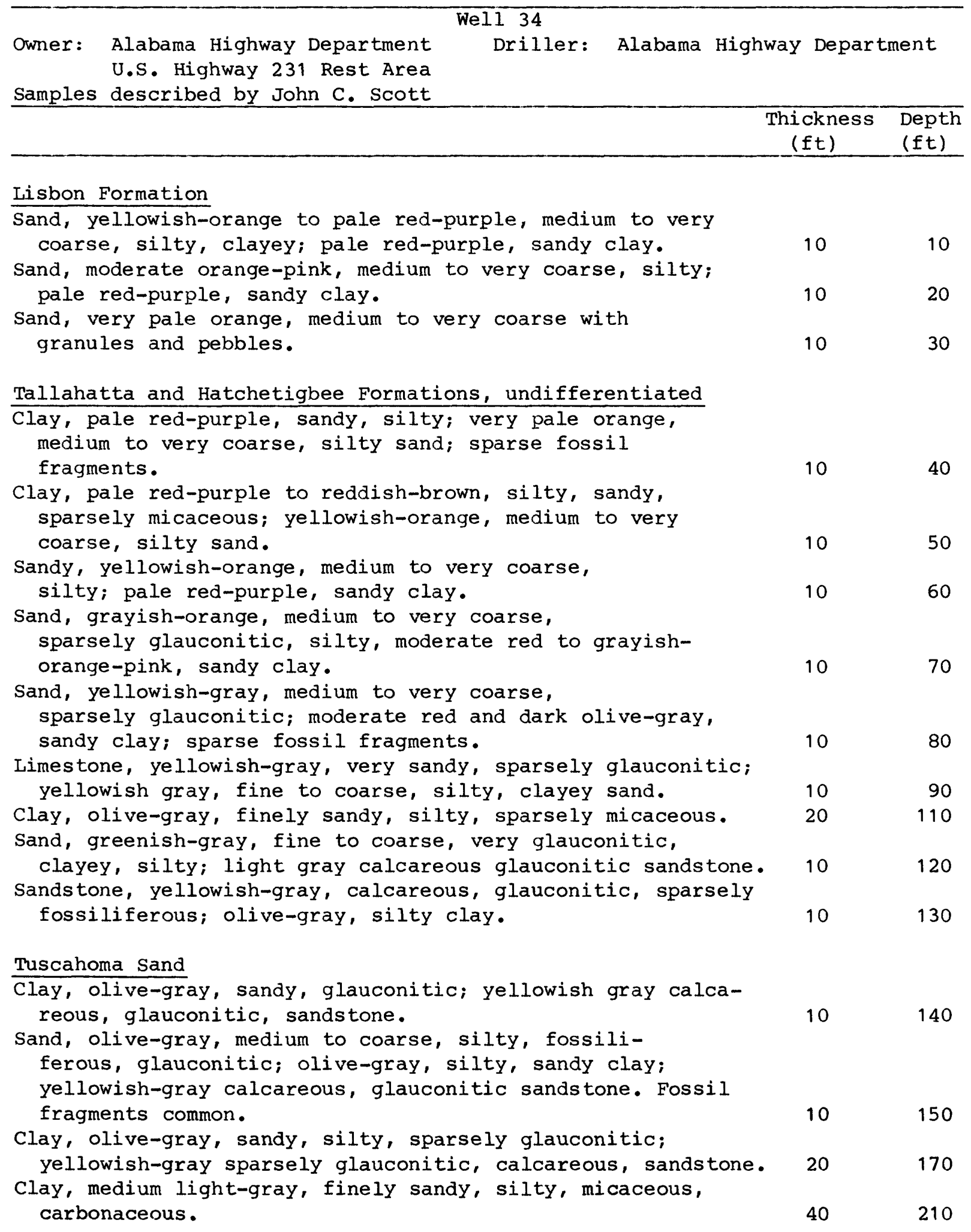


Table 2.--Sample logs of wells in the Fort Rucker area--Continued

Well 34

Thickness Depth

(ft) (ft)

Tuscahoma sand (continued)

Clay, light olive-gray, sandy, silty, micaceous, carbonaceous, sparsely glauconitic.

Sand, light gray, medium to very coarse, silty, sparsely glauconitic; light olive-gray, micaceous, carbonaceous, sandy clay.

Sand, light gray, medium to very coarse, sparsely glauconitic, silty; light gray calcareous fossiliferous, sandstone; fossil fragments common to abundant. 
Table 2.--Sample logs of wells in the Fort Rucker area--Continued

\begin{tabular}{ll}
\hline Owner: U.S. Geological Survey & Well 35 \\
- & Dale County Observation Well
\end{tabular}
Samples described by Jack T. Kidd, Geological Survey of Alabama

$\begin{array}{cc}\text { Thickness } & \text { Depth } \\ (\mathrm{ft}) & (\mathrm{ft})\end{array}$

Quaternary terrace deposits

Sand, grayish-orange, fine to very coarse, subangular to subrounded, consists of predominantly clear quartz coated with grayish-orange clay.

Sand, same, increase in coarse to very coarse, some granules; several fragments of parent material present which consist of clayey sand, composed of light gray and light brown clay matrix with fine to very coarse sand.

Sand and gravel, very pale orange, medium sand to very fine gravel, quartzose, subangular to subrounded, some grayishorange clay staining; heavy minerals common, including kyanite, and unidentified black and amber minerals.

Hatchetigbee Formation

Clayey sand or sandy clay, very glauconitic, consists of moderate reddish-brown clay, same very pale orange and grayish-orange-pink clay streaks, and sand, fine to medium, some coarse, subangular.

Clayey sand, sandy clay, and clay, predominantly grayishorange glauconitic clayey sand, fine to medium, with lesser amounts of very pale orange clay, and grayishred sandy clay.

Tuscahoma Sand

Sand, grayish-orange, fine to very coarse, subangular to subrounded, glauconitic, quartzose, some pebbles; sandy clay and clayey sand, grayish-orange fine to very coarse, glauconite; small amount of clay, grayish-orange and very light gray.

Sand, same; clay, very light gray, very finely micaceous; clay, dark yellowish-orange, fine sandy, glauconitic.

Clay, light gray, some orange laminae, very finely micaceous, some fragments sandy due to apparent mixing and coating during drilling; sand, grayish-orange, fine to very coarse, some pebbles, subangular to subrounded, quartzose, glauconitic.

Clay, light gray, very finely micaceous; clayey silty sand, grayish-orange, very fine to fine, glauconitic, micaceous; sand, light gray to grayish-orange, fine to very coarse, some pebbles, subangular to subrounded.

$\begin{array}{ll}10 & 90 \\ 10 & 100 \\ 10 & 110\end{array}$

Silty clay and siltstone, medium light gray, very micaceous, glauconitic, carbonaceous. 
Table 2.--Sample logs of wells in the Fort Rucker area--Continued

Well 35

Thickness Depth

(ft)

$(\mathrm{ft})$

Tuscahoma Sand (continued)

Silty clay and siltstone, same.

20

130

Silty shale and siltstone, same; sand, light gray to

greenish-gray, coarse to very coarse, subangular to sub-

rounded, quartzose, large glauconite grains, trace of

pyrite.

10

140

Sand, greenish-gray to light gray, coarse to very coarse, subangular to subrounded, quartzose, very glauconitic, contains shell fragments (oysters?), grades into sandy limestone; few large fragments of claystone, light gray; small pecten noted.

Sandy limestone, very light gray to yellowish-gray composed of sand, clear to greenish-gray, medium to very coarse, subangular to subrounded, quartzose, with glauconite, shell fragments and matrix of indurated white lime and lesser amounts of light olive-gray less indurated marly matrix; large amounts of loose sand, assumed to be derived from sandy limestone.

Sandy limestone and sand, same, predominantly sandy limestone with light olive-gray marly matrix; shell fragments.

Sandy limestone with white matrix, same; sand, same; shell fragments.

Sandy limestone, same; sand, same; shell fragments, trace of pyrite.

Sand, clear to greenish-gray, medium to very coarse, subangular to subrounded, quartzose, very glauconitic, small percentage of sand cemented by marly matrix and parent rock for sand appears to be marly sand; small amount of white sandy limestone; trace of moderate reddish-brown sandy clay; shell fragments, forams.

Sandy, silty marl, glauconitic, very calcareous, grades into sandstone, light gray, very fine to medium, some coarse; small amount of white sandy marl; shell fragments.

Sand, light gray, to greenish-gray, very fine to very coarse, subangular to subrounded, quartzose, silty calcareous matrix in part; shell fragments, fish teeth, phosphate, glauconite.

Silty sand, light gray, very fine to medium, some coarse, glauconitic, micaceous, calcareous in part, grades into silty sandy marl in part; shell fragments, fish teeth, phosphate glauconite.

Silty sand, medium light gray, very fine to fine, some medium to coarse, subangular to subrounded, quartzose, micaceous, glauconitic, very silty, some fragments slightly calcareous due to scattered shell fragments. 
Table 2.--Sample logs of wells in the Fort Rucker area--Continued

We11 35

Thickness Depth

(ft)

(ft)

Tuscahoma Sand (continued)

Calcareous siltstone and/or silty sandstone, light gray, composed of silt and very fine clear quartz sand, calcareous matrix, some scattered fine to coarse sand, shell fragments.

Nanafalia Formation

Sandy lime-sandy marl-calcareous sand, light gray, composed of clear very fine to very coarse quartz in indurated lime matrix and less indurated marly matrix; numerous shell fragments and one shark tooth noted.

Calcareous sand, sandy lime, sandy marl, light gray, composed of clear to light gray to greenish-gray, very fine to very coarse quartz sand, in lime or marl matrix; numerous shell fragments; Nummulites.

Sandy lime, calcareous sand, medium light gray, glauconitic, micaceous, fossiliferous, sand is colorless to light greenish gray, very fine to very coarse, subangular to subrounded, quartzose; shell fragments.

Sand, colorless to light gray, coarse to very coarse; subangular to subrounded, quartzose; trace of light greenishgray sand; trace of pyrite.

Sand and gravel, light gray, coarse sand to very fine pebbles, predominantly subrounded, quartzose, most grains have small amount of dark gray clay coating, some grains coated or cemented with pyrite; shell fragments; small amounts of various lithologies probably from cavings.

Lignitic sand, brownish-black to brownish-gray, very fine to very coarse, subangular to subrounded, pyritic, sand present as coarse dark coated loose grains and as very fine to fine grains in a lignitic matrix.

Same, some fragments grade into silty and very fine sandy lignite; large flakes of muscovite.

Same.

Sandy and clayey silt, medium gray, fine to very coarse sandy, very micaceous with large flakes of muscovite, glauconitic.

Silt, medium dark gray, clayey, very micaceous with large muscovite flakes, very fine to fine sandy, some scattered coarser grains, carbonaceous in part.

Lignitic sandy siltstone, dark gray to brownish-black, consists of siltstone in a lignite or carbonaceous matrix with abundant very fine to very coarse subangular to subrounded quartz sand, abundant muscovite, few shell fragments. 
Table 2.--Sample logs of wells in the Fort Rucker area--Continued

Well 35

Thickness Depth

(ft)

(ft)

Clayton Formation

Chalky limestone, very light gray to yellowish-gray, bioclastic.

Carbonaceous silty sand, medium gray, very fine to fine, some medium to very coarse, subangular to subrounded, various amounts of pyrite, muscovite, glauconite, carbonized wood; small amount of shale, brownish-gray.

Chalky limestone, very light gray to yellowish-gray, fine to coarse sandy, fossiliferous; sand, light gray, very fine to medium, some coarse to very coarse, subangular to subrounded, quartzose, glauconitic, micaceous; trace of silty sandstone.

Chalky limestone, very light gray, bioclastic.

Chalky limestone, same and sandy in part.

Sand, colorless to light gray, coarse to very coarse, subangular to subrounded, quartzose; chalky limestone, same; silty carbonaceous shale, probably cavings.

Sand, same.

Sandy, limestone, pinkish gray to very light gray, contains fine to coarse colorless quartz sand, fossiliferous.

Same.

Sand, colorless to light gray, medium to very coarse, subangular to subrounded, quartzose, some grains coated with white chalky material indicating the sand was derived from a calcareous sandstone or a rotten sandy chalk; sandy limestone same as above; trace of glauconite; fossils gastropod, echinoid spine, forams.

Sandy, limestone, very light gray (fresh), most fragments coated with light olive-gray clay, probably during drilling, otherwise same as sandy limestone above.

10

10

10

10

10

Providence Sand

Silty sandy chalk, light olive-gray, sand is fine to coarse, subangular to subrounded quartz; sandy limestone, same as above; glauconite, gastropod, forams; abundant sand, probably derived from chalk and limestone, colorless with trace of grayish orange, fine to very coarse.

Sandy limestone, very light gray, glauconitic in part, fossiliferous, sand is colorless to light gray, fine to coarse, subangular to subrounded; abundant sand, probably derived from sandy limestone, same; silty chalk, same;

fossils - bryozoans, shell fragments.

Sandy limestone, same, grades into calcareous sandstone, and sandy silty chalk, very micaceous, glauconitic; abundant sand, colorless to light gray, trace of grayishorange, fine to very coarse, subangular to subrounded, quartzose. 
Table 2.--Sample logs of wells in the Fort Rucker area--Continued

We11 35

Thickness

Depth

(ft)

(ft)

Providence Sand (continued)

Sandy limestone, same; abundant sand, same; trace of clay, moderate red.

Sandy limestone, same; sand, same, slight increase in

yellowish-gray grains, but still only a very small

percentage of total sand; trace of sandy clay - clayey

sand, dark yellowish-orange, very fine to fine.

Sandy limestone, same; sand, same; trace of clay, moderate

red, fine sandy (only 2 or 3 fragments present). 
Table 2.--Sample logs of wells in the Fort Rucker area--Continued

Wel1 63

Owner: Meadow Lawn Cemetery

Samples described by Eleanor $T$. Caldwell

Driller: Burrell Drilling Company

\begin{tabular}{|c|c|c|}
\hline & $\begin{array}{l}\text { Thickness } \\
\text { (ft) }\end{array}$ & $\begin{array}{l}\text { Depth } \\
(\mathrm{ft})\end{array}$ \\
\hline Iron stained sand. & 90 & 90 \\
\hline Same; red and pale green clay. & 45 & 135 \\
\hline Fine to coarse, gray, glauconitic sand. & 44 & 179 \\
\hline Fine to very coarse, gray, glauconitic, argillaceous sand. & 24 & 203 \\
\hline Fine to coarse, green, glauconitic sand. & 23 & 226 \\
\hline $\begin{array}{l}\text { Same; white, hard, fossiliferous, sandy limestone; gray, } \\
\text { soft, micaceous, glauconitic, silty marl; trace of dark }\end{array}$ & & \\
\hline gray, soft, micaceous, carbonaceous, noncalcareous shale. & 23 & 249 \\
\hline Same. & 47 & 296 \\
\hline $\begin{array}{l}\text { Fine to coarse, gray, glauconitic, shelly sand; dark gray } \\
\text { shale as above; fragments of gray, hard, fossiliferous, } \\
\text { glauconitic, very sandy limestone. }\end{array}$ & 46 & 42 \\
\hline Dark gray, soft, sticky, micaceous, carbonaceous, non- & & \\
\hline calcareous : & 15 & 457 \\
\hline $\begin{array}{l}\text { Mostly shale as above; trace of green, coarse, glauconitic } \\
\text { sand. }\end{array}$ & 23 & 480 \\
\hline $\begin{array}{l}\text { Fine to coarse, green, glauconitic sand; rare shell fragments. } \\
\text { Same; fragments of white, hard, slightly glauconitic, very }\end{array}$ & 23 & 503 \\
\hline $\begin{array}{l}\text { sandy limestone. } \\
\text { Mostly sand as above; some coarse orange sand; abundant shell }\end{array}$ & 68 & 571 \\
\hline fragments. & 23 & 594 \\
\hline $\begin{array}{l}\text { Fine to coarse, clayey and limey, fossiliferous sand; common } \\
\text { shell fragments; corded Camerina common. } \\
\text { White, porous, coquinoid limestone; calcareous algae; shell }\end{array}$ & 46 & 640 \\
\hline fragments. & 163 & 803 \\
\hline
\end{tabular}


Table 2.--Sample logs of wells in the Fort Rucker area--Continued

Owner: U.S. Army - Fort Rucker Well 9 , 70

Samples described by John C. Scott

Driller: Layne-Central Company

$\begin{array}{ccc}\text { Thickness } & \begin{array}{c}\text { Depth } \\ (\mathrm{ft})\end{array} \\ (\mathrm{ft})\end{array}$

Tallahatta and Hatchetigbee Formations

Sand, dark yellowish-orange, medium to very coarse, angular to subangular, silty.

10

36

Sand, dark yellowish-orange, medium to very coarse, angular to subangular, silty, sparsely glauconitic. (Glauconite is weathered to pale green).

Sand, yellowish-gray, fine to coarse, angular to subangular, glauconitic, slightly silty. Light olivegray finely micaceous clay.

Sand, yellowish-brown to grayish-brown, medium to very coarse, glauconitic, silty. Fossil fragments and microfossils common. Medium gray sandy, silty glauconitic, micaceous clay. Most sand grains are coated with iron oxide.

Clay, light olive-gray, sandy, silty, glauconitic, micaceous. Fossils and fossil fragments scarce.

Sand and calcareous sandstone, light olive-gray, medium to coarse, very glauconitic, fossiliferous, fossils and fragments common: Light olive-gray calcareous sandy clay. Calcareous sandstone is cemented with soft limestone.

Tuscahoma Sand (160 feet from E-log)

Clay, light olive-gray, sandy, calcareous, glauconitic, very fossiliferous, lignitic, light gray calcareous sandstone.

Clay, light olive-gray, slightly sandy, micaceous, sparsely lignitic. A few fragments of white limestone.

Clay, olive-gray, silty, micaceous, sparsely lignitic.

Sand, greenish-gray, medium to coarse, very glauconitic. Olive-gray, silty micaceous clay; a few fragments of calcareous sandstone.

sand, greenish-gray, medium to coarse, glauconitic, micaceous, sparsely fossiliferous. Yellowish-gray to white calcareous sandstone. Olive-gray silty clay. Fossil fragments common.

Nanafalia Formation ( 300 feet from E-log)

Sand, greenish-gray, medium to coarse, glauconitic, sparsely pyritic; some grains stained and coated with iron. Pale orange to white glauconitic mudstone (siltstone). Olive-gray silty clay. Top Tnf (?).

Sand, greenish-gray, fine to medium, glauconitic, sparsely micaceous. Light olive-gray silty clay. 
Table 2.--Sample logs of wells in the Fort Rucker area--Continued

We11 70

Thickness Depth

(ft)

$(f t)$

Nanafalia Formation (continued)

Sandstone, light greenish-gray, calcareous, fossiliferous; microfossils and fossil fragments common to abundant. Olive gray sandy clay. Greenish-gray coarse to very coarse silty sand. Large sand grains are mostly subrounded.

Calcareous sandstone and sand same as above except fossils and fragments more abundant. Odontogryphaea thirsae, corals and microfossils (O. thirsae zone [?]).

Sand, greenish-gray, mostly medium to coarse, silty glauconitic, fossiliferous, lignitic. Light gray to white calcareous sandstone.

Clayton Formation (432 feet from E-log)

Limestone, very pale orange to white, slightly sandy, very fossiliferous (fossils comprise more than half of limestone). Light greenish gray calcareous sandstone. Olive-gray silty lignitic clay.

Limestone, yellowish-gray, very fossiliferous.

Limestone, same as above except composed almost entirely of fossils and fossil fragments.

Limestone, yellowish-gray to white, very fossiliferous.

Limestone, same as above except slightly darker yellowishgray.

Limestone, yellowish-gray to light olive-gray, very fossili-

Providence Sand (595 feet from E-log)

Sand, light greenish-gray to yellowish-gray, medium to very coarse, sparsely glauconitic, fossiliferous.

Yellowish-gray to white calcareous sandstone.

Sand, yellowish-gray, medium to very coarse, sparsely glauconitic and fossiliferous (glauconite and fossils may be from above). A few fragments of pyrite.

Sand, yellowish-gray, mostly medium to coarse, sparsely glauconitic and fossiliferous. Light gray to white calcareous sandstone.

Limestone, yellowish-gray to light olive-gray, sandy, fossiliferous. Very light gray to white calcareous sands tone.

Sand, yellowish-gray to white, coarse to very coarse, calcareous, fossiliferous. Light gray to white calcareous sandstone.

Sand, yellowish-gray, medium to very coarse, fossiliferous (corals abundant). Light gray to white calcareous sandstone. Yellowish-gray to yellowishorange silty sand mottled and stained with iron. 
Table 2.--Sample logs of wells in the Fort Rucker area--Continued

Well 70

Thickness Depth

(ft)

$(f t)$

Providence Sand (continued)

Clay, olive-gray, sandy, silty, fossiliferous, carbonaceous calcareous. Light gray to white calcareous sandstone.

Clay, light olive-gray, sandy, fossiliferous, calcareous, silty.

Sand, yellowish-gray, mostly medium to coarse, silty,

calcareous, sparsely fossiliferous. Light gray to white

calcareous sandstone.

796

Ripley Formation (810 feet from E-log)

Clay, yellowish-gray to light olive-gray, sandy, silty, calcareous. Light greenish-gray, medium to coarse silty sand.

Sandstone, light gray to white, calcareous, pyritic, fossiliferous. Light gray to white, medium to very coarse silty sand. Greenish-gray calcareous sandstone.

Sand, light greenish-gray, fine to medium, silty, micaceous, carbonaceous (calcareous matrix). Light gray to white calcareous sandstone. A few fossil fragments.

Sandstone, light gray to white, calcareous, fossiliferous. Light greenish gray, fine to medium micaceous, silty sand. Fossil fragments common.

Sand, greenish-gray, fine to medium, silty, micaceous. Greenish gray sandy, micaceous clay. Light gray to white calcareous sandstone.

Sample missing

Clay, greenish-gray to olive-gray, finely sandy, silty, micaceous, carbonaceous, calcareous.

Clay, greenish-gray to olive-gray, finely sandy, silty, micaceous, carbonaceous, calcareous. A few microfossils and fossil fragments.

Sand, greenish-gray, fine to medium, finely glauconitic, silty. Greenish-gray, silty carbonaceous clay. Light gray to white calcareous sandstone.

clay, light olive-gray, silty, finely sandy, micaceous, calcareous. Greenish-gray, fine, silty sand.

clay, light olive-gray, silty, calcareous, carbonaceous, micaceous. 
Table 2.--Sample logs of wells in the Fort Rucker Area--Continued

\section{Well 72}

Owner: U.S. Army - Fort Rucker Well 8 Driller: Layne-Central Company Samples described by Charles w. Copeland, Geological Survey of Alabama; formation boundaries determined by John C. Scott, U.S. Geological survey

Thickness Depth (ft) (ft)

Tallahatta and Hatchetigbee Formations

Sand, very pale orange, fine to coarse, subangular to subrounded, quartzose with weathered glauconite and traces of kyanite.

Sand, very pale orange, fine to very coarse, subangular to subrounded, quartzose, glauconitic with minor amounts of medium light gray, carbonaceous clay and yellowish-gray to grayish-green, calcareous, glauconitic, marl or claystone.

Limestone, very light gray to light greenish-gray, sandy, glauconitic, fossiliferous; sand, very light gray, fine to medium, subangular to subrounded, quartzose, glauconitic; fossils, mainly fragments of pelecypod shells and bryozoans.

Tuscahoma Sand

Clay, medium light gray, silty, slightly micaceous and carbonaceous; sand, very light gray, fine to medium, subangular to subrounded, quartzose, glauconitic.

Clay and sand, same.

clay, medium light gray, silty, micaceous, carbonaceous with limestone from above; few pieces of indurated, gray, fine grained, calcareous, sandstone.

Sand, very light gray to light greenish-gray, medium to coarse, subangular to subrounded, quartzose, glauconitic; trace of medium light gray, carbonaceous clay.

Nanafalia Formation (Top at 260 feet from E-log)

Sand, some with minor amounts of medium gray clay and white, finely sandy, glauconitic, limestone.

Sand, very light gray, fine to medium with some coarse, subangular to subrounded, quartzose, glauconitic, fossiliferous; trace gray clay; fossils, mainly fragments of oyster shells.

Sand, same, abundantly fossiliferous with white, finely sandy, argillaceous limestone; few forams, ostracods, abundant oyster shell fragments.

Sand, very light gray, medium to coarse, subangular to subrounded, quartzose, fossiliferous with glauconite trace; abundant oyster shell fragments, echinoid fragments and large forams, Numulities. 
Table 2.--Sample logs of wells in the Fort Rucker area--Continued

Well 72

Thickness Depth

(ft)

$(f t)$

Nanafalia Formation (continued)

Sand, very light gray and yellowish-gray, medium to coarse, subangular to subrounded, quartzose, fossiliferous; limestone, white, sandy, fossiliferous; shell debris and microfossils.

Clayton Formation

Limestone, white, sandy in part, coquinoidal in part, abundantly fossiliferous; mainly molds and casts.

Limestone, white, mainly coquinoidal.

$45 \quad 464$

Limestone, same; bryozoans abundant.

23

487

Limestone, same and limestone, light olive-gray, porous with saccharoidal texture and appearance.

Limestone, white, mainly coquinoidal.

Sand, very light gray to white, fine to coarse, subangular to subrounded, quartzose, fossiliferous, slightly glauconitic; limestone, white, coquinoidal; few ostracods and benthonic foraminifers.

Sand, same, calcite cemented in part; limestone, coquinoidal, same and some white, medium to coarse, sandy limestone.

Providence Sand (Top at 570 feet from E-log)

Sand, white, medium to coarse, quartzose; limestone, sandy and coquinoidal, same.

Limestone, white, medium to coarsely sandy, fossiliferous; limestone, coquinoidal, same, in lesser amounts; sand, same.

Limestone, white, coquinoidal in part, fossiliferous, and limestone, very light gray to white, medium to coarse sandy, porous, leached in part, with saccharoidal appearance; sand, medium to coarse, subangular to subrounded, quartzose; pyrite trace; few leached benthonic foraminifers and ostracods.

Limestone, coquinoidal and sandy, same; sand, same.

Limestone, same, slightly glauconitic; sand, same, some grains yellowish-gray; limestone, light gray, very finely sandy and silty; trace medium gray, finely sandy, slightly calcareous clay.

Limestone, same with clay, medium gray, finely sandy, slightly calcareous; few benthonic foraminifers.

Sand, very light gray to yellowish-gray, medium to very coarse, subangular to subrounded, poorly sorted, quartzose; clay, medium gray to yellowish-gray, finely sandy, limestones from above. 
Table 2.--Sample logs of wells in the Fort Rucker area--Continued

Well 72

Thickness Depth

(ft)

(ft)

Providence Sand (continued)

Limestone, white to yellowish-gray, medium to coarsely

sandy, fossiliferous; sand, medium to very coarse,

same; shell fragments.

Sand, very light gray to yellowish-gray, subangular to subrounded, quartzose, clayey; limestone, very light gray, silty, very finely sandy with trace of glauconite; clay is medium light gray, very finely sandy, calcareous.

Ripley Formation (Top at 775 feet from E-log)

Sand, very light gray to white, medium, subangular to subrounded, quartzose with glauconite trace.

Sand, very light gray to white, fine to medium, subangular to subrounded, quartzose with glauconite and mica trace; limestone, white, finely sand; trace medium gray clay.

Sand, same; limestone, same in minor amounts; clay trace, same.

Sand, very light gray to white, fine to medium, subangular to subrounded, quartzose, slightly glauconitic and micaceous; micas are muscovite and chlorite.

Sand, same with muscovite, chlorite, and possible biotite micas; limestone, white, finely sandy; clay, medium gray, silty, in trace amounts.

Sand, very light gray to white, subangular to subrounded, quartzose, micaceous, slightly glauconitic, fossiliferous; few benthonic foraminifers; clay, medium light gray to yellowish-gray, finely sandy.

Sand, very light gray to white, subangular to subrounded, quartzose, micaceous (mainly muscovite), slightly glauconitic.

Sand, same with light gray, finely sandy limestone and pyrite.

Sand, same with light gray, finely sandy limestone, pyrite and abundant fragments of oyster shells.

Sand, same with light gray, finely sandy limestone and pyrite.

Sand, same and sandy limestone, same; limestone and sand percentage in the chips is about equal.

Sand, same and sandy limestone or limey sandstone, same; benthonic foraminifers and ostracods.

Sand, same and light gray, finely sandy, micaceous, calcareous clay; ostracods.

Sand, same and light gray, finely sandy, micaceous, calcareous, fossiliferous, chalky clay or calcareous clay; calcareous and arenaceous benthonic foraminifers and ostracods. 
Table 2.--Sample logs of wells in the Fort Rucker area--Continued

\section{Well 76}

Owner: U.S. Army - Ft Rucker Cairns Airfield Driller: Layne-Central Company Samples described by Neil E. Moss, Geological Survey of Alabama; formation boundaries determined by John C. Scott, U.S. Geological Survey.

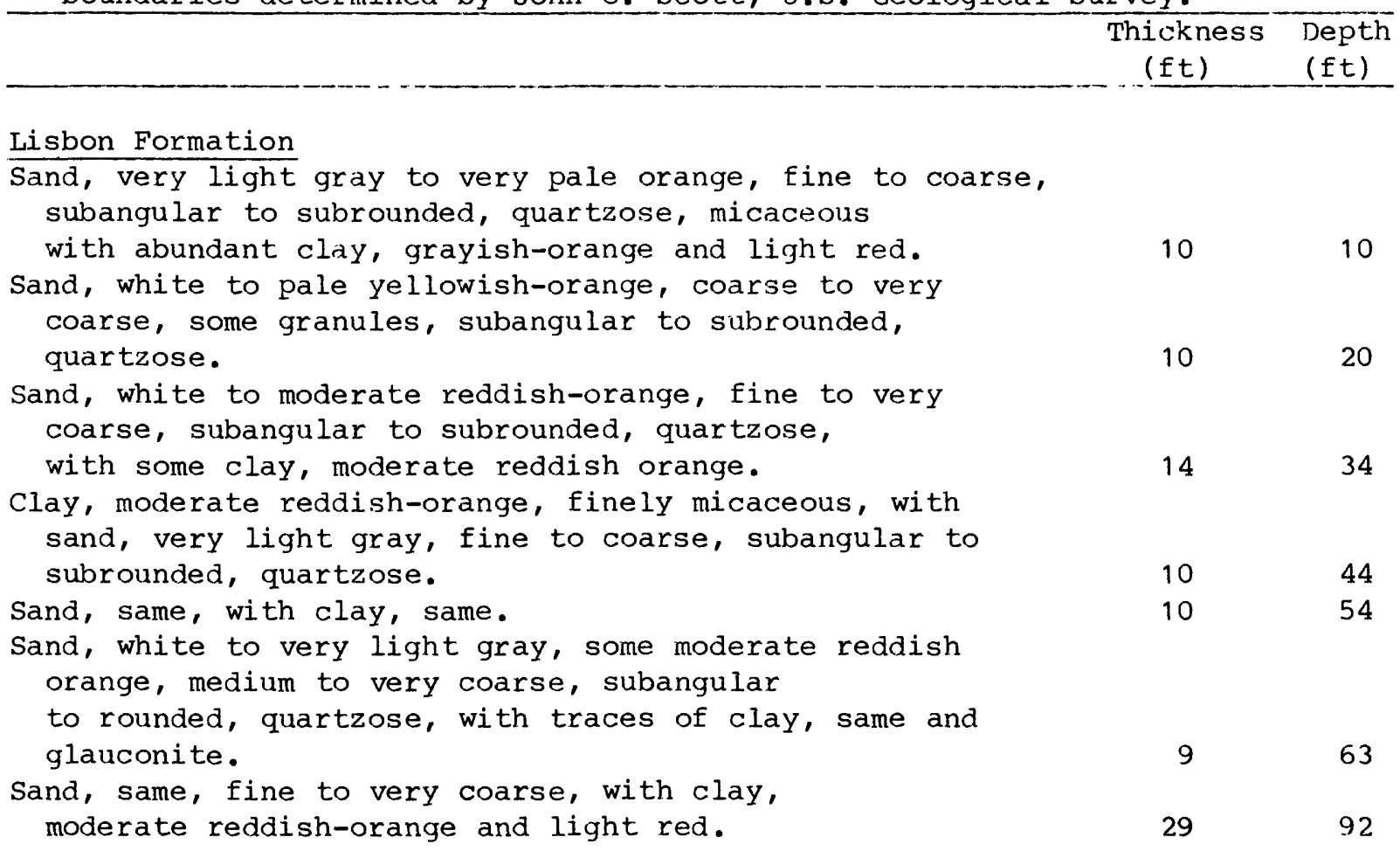

Tallahatta and Hatchetigbee Formations

Sand, white to very light gray to grayish-yellow to pale yellowish-green, fine to very coarse, subangular to subrounded, quartzose, glauconitic, with limestone, very light to yellowish-gray, very finely crystalline, clay, yellowish to light olive-gray, and fragments of pelecypods, gastropods, and echinoderms.

Sand, same, except with limestone, pale yellowish-orange to very light gray.

Shell fragments, pelecypod, gastropod, bryozoan, and echinoderm, with glauconite, and trace of sand.

Clay, medium to light olive-gray, finely micaceous, glauconitic, carbonaceous.

Tuscahoma sand (top at 186 feet from E-log)

Clay, same, except light olive to olive-gray

Clay, same, light olive-gray

Sand, white to yellowish-gray, fine to very coarse, subangular to subrounded, quartzose, glauconitic, with limestone, yellowish-gray, very finely crystalline, clay, same, and fragments of gastropods, pelecypods, and echinoderms. 
Table 2.--Sample logs of wells in the Fort Rucker area--Continued

Well 76

\begin{tabular}{l}
\hline Tuscahoma Sand (continued) \\
Sand, very light to yellowish-gray, fine, \\
subangular to subrounded, quartzose, glauconitic, \\
micaceous, with clay, same. \\
Clay, light olive-gray, some moderate reddish-orange, \\
micaceous, carbonaceous, glauconitic, sandy, fossili- \\
ferous, foraminifera, trace shell fragments. \\
Clay, light olive-gray, micaceous, glauconitic, slightly \\
sandy, with foraminifera. \\
Sand, very light gray to pale olive, medium to very \\
coarse, subangular to subrounded, quartzose, \\
glauconitic with trace clay and shell fragments. \\
Sand, same, with clay light greenish-gray and moderate \\
reddish-orange. \\
Sand, same. \\
Sand, same, medium. \\
Sand, same.
\end{tabular}

Nanafalia Formation (Top at 378 feet from E-log)

Sand, same, with limestone, very light to yellowishgray, very finely crystalline, fossiliferous, foraminifera, fragments of pelecypods, gastropods, and echinoderms.

Sand, very light gray to yellowish-gray, fine to coarse, subangular to subrounded, quartzose, glauconitic, micaceous, with abundant clay, light olive gray, and foraminifera.

Sand, very light gray, mostly fine, some medium to coarse grained, subangular to subrounded, quartzose, glauconitic, micaceous, with abundant clay, same, and foraminifera.

Sand, same, trace clay, with fragments of pelecypods, gastropods, and echinoderms, and trace limestone, very light gray, very finely crystalline.

Sand, same as 424-434, except very light to yellowish gray, fine to very coarse.

Sand, very light to yellowish-gray, fine to very coarse, subangular to subrounded, quartzose, glauconitic, with clay, light olive-gray, carbonaceous, some moderate reddish orange and shell fragments and foraminifera.

Sand, white to yellowish-gray, medium to very coarse, subangular to subrounded, quartzose, slightly glauconitic, with limestone, very light gray, very finely crystalline, trace shell fragments, and trace foraminifera. 
Table 2.--Sample logs of wells in the Fort Rucker area--Continued

We11 76

Thickness Depth

(ft)

(ft)

Nanafalia Formation (continued)

Sand, same, with abundant clay, light olive to light brownish-gray, carbonaceous, micaceous.

Sand, white to yellowish-gray, some pale yellowishorange, medium to very coarse, subangular to subrounded, quartzose, slightly glauconitic, with fragments of gastropods, bryozoans, pelecypods, and echinoderms.

Clayton Formation (By E-log at $512 \mathrm{ft}$; by samples at $516 \mathrm{ft}$ )

Limestone, yellowish-gray to pale orange, very finely crystalline, sandy, slightly glauconitic, with bryozoan, pelecypod, gastropod, and echinoderm fragments, foraminifera.

Clay, light olive-gray and moderate reddish-orange, micaceous, silty.

Limestone, same as 516-528.

Clay, same as 528-538, with sand and limestone, same.

Limestone, same.

Limestone, same, with clay, moderate reddish-orange.

Sand, very light gray to white, medium to very coarse,

Providence Sand (Top at $670 \mathrm{ft}$ from E-log)

Limestone, yellowish-gray to very pale orange, very finely crystalline, fossiliferous, foraminifera, ostracods, bryozoan, pelecypod, echinoderm fragments, with sand, same. 21

Limestone, same, except with trace fine sand, trace clay, brownish-gray, carbonaceous and fossils, trace.

Sand, yellowish-gray to white, medium to very coarse, subangular to subrounded, quartzose, slightly glauconitic, with limestone, same.

Sand, same, some pale yellowish-gray, with some clay, light olive-gray, trace.

Limestone, very light gray to very pale orange, very finely crystalline, slightly fossiliferous, shell fragments, microfossils, with sand, same; (limestone is caved material from Clayton Formation). 
Table 2.--Sample logs of wells in the Fort Rucker area--Continued

Wel1 76

Thickness Depth

(ft) (ft)

Ripley Formation

Sand, very light gray to pale yellowish-orange, medium

to very coarse, subangular to subrounded,

quartzose, slightly glauconitic with foraminifera,

ostracods, shell fragments, with limestone, very

light gray, very finely crystalline.

83

987

Sand, same, with more limestone.

43

1030 
Table 2.--Sample logs of wells in the Fort Rucker area--Continued

Well 79

Owner: U.S. Army - Fort Rucker Well 10 Driller: Layne-Central Company Samples described by John C. Scott

Thickness Depth

(ft) (ft)

Lisbon Formation

Sand, moderate reddish-brown, fine to medium, glauconitic, silty, iron stained, sparsely micaceous, loosely cemented, pale red-purple sparsely glauconitic clay. Glauconite occurs mainly as coating on clay pieces.

Sand, moderate orange-pink, medium to coarse, sparsely glauconitic. Glauconite is deeply weathered (light olive-green).

Tallahatta and Hatchetigbee Formations

Clay, medium light gray, sandy, glauconitic (black glauconite), light gray slightly calcareous sandy siltstone. Moderate reddish-brown silty clay. Yellowish-orange to yellowish-gray medium to coarse glauconitic sand.

Clay, medium gray, very fossiliferous (micro and macro fossils), calcareous, very glauconitic, slightly sandy. Most of the sample is composed of fossils and glauconite.

Siltstone and calcareous sandstone, medium gray to medium light gray, very fossiliferous, glauconitic. Fossil fragments abundant.

Tuscahoma Sand (135 ft from E-log)

Clay, medium gray, silty, glauconitic fossiliferous, slightly sandy.

Sand, medium light gray, medium to very coarse, glauconitic. Some medium gray clay and light gray calcareous sandstone in sample.

Nanafalia Formation (270 ft from E-log)

Clay, medium light gray, silty, carbonaceous. Light gray, fine to medium glauconitic sand. Very light gray to white calcareous glauconitic fossiliferous sandstone. Fossil fragments common.

Sand, greenish-gray, coarse to very coarse, glauconitic. Very light gray to white calcareous glauconitic sparsely fossiliferous sandstone.

Sand, greenish gray, glauconitic, fossiliferous, medium gray carbonaceous clay. Light gray to white calcareous fossiliferous sandstone.

Sand, greenish-gray, fine to medium, silty, glauconitic, sparsely fossiliferous. 
Table 2.--Sample logs of wells in the Fort Rucker area--Continued

We11 79

Thickness Depth

(ft)

$(\mathrm{ft})$

Nanafalia Formation (continued)

Sand, greenish-gray, medium to very coarse, glauconitic, very fossiliferous. Light greenish-gray

to white calcareous, glauconitic fossiliferous sandstone.

32

410

Sand, greenish-gray, coarse to very coarse, very

fossiliferous, carbonaceous; micro fossils and fossil

fragments abundant. Very light gray to white calcareous

sands tone.

Clayton Formation

Limestone, yellowish-gray, very fossiliferous. Sample

composed mainly of fossils and fossil fragments.

62

Same as above except fossil content less.

Sand and calcareous sandstone, very light gray to white, coarse to very coarse, fossiliferous, sparsely

glauconitic. Yellowish-gray fossiliferous sandy limestone.

Providence Sand ( $590 \mathrm{ft}$ from E-log)

Sand, very pale orange to white, medium to very coarse, sparsely fossiliferous (fossils may be from

limestone and calcareous sandstone above). Small amounts

of limestone and calcareous sandstone in sample.

Same as above except sand is mostly medium to coarse.

Sand, medium gray, moderate reddish-brown, pale red-purple, and moderate yellow, fine to very coarse, very

clayey; a few fossil fragments present. Appear to be a

"mish-mash" of reworked sediments.

Sand, medium light gray, medium to very coarse, very silty, calcareous, carbonaceous. Some calcareous sandstone and fossil fragments in sample.

Ripley Formation ( $790 \mathrm{ft}$ from E-log)

Same as above except sand is mostly fine to medium.

Some hard calcareous sandstone in sample.

Sand, light olive-gray, fine to medium, silty, calcareous, micaceous, sparsely glauconitic. Some olive-gray clay and calcareous sandstone in sample.

Sand as above except sand is mostly fine and sample contains a few fossil fragments.

Sand, light olive-gray, very fine to fine silty, clayey, micaceous, calcareous, sparsely 
Table 2.--Sample logs of wells in the Fort Rucker area--Continued

We11 79

Thickness Depth

$(f t) \quad(f t)$

Ripley Formation (continued)

Clay, medium gray, very finely sandy calcareous, finely micaceous.

Clay, medium gray, sandy, sparsely micaceous, light gray, medium to very coarse, silty sand.

Sand, light gray, medium to very coarse, very silty, clayey, calcareous, carbonaceous, sparsely micaceous.

Sand, light gray, medium to coarse (some very coarse), very silty, clayey, calcareous.

Clay, medium gray to light gray, very finely sandy, calcareous, sparsely micaceous. 
Table 2.--Sample logs of wells in the Fort Rucker Area--Continued

\begin{tabular}{|c|c|c|}
\hline \multicolumn{3}{|l|}{ Well 90} \\
\hline Owner: City of Dothan - Napier Field & yne-Central & Co. \\
\hline & $\begin{array}{l}\text { Thickness } \\
(f t)\end{array}$ & $\begin{array}{l}\text { Depth } \\
\text { (ft) }\end{array}$ \\
\hline Brown sandy clay. & 2 & 2 \\
\hline Red sandy clay. & 26 & 28 \\
\hline $\begin{array}{l}\text { Pink, yellow, white and tan mottled sandy clay. Mica noted. } \\
\text { Red, yellow, and gray clay with coarse grains and granules }\end{array}$ & 19 & 47 \\
\hline of quartz. & 18 & 65 \\
\hline Yellow-tan clay and medium to coarse quartz grains. & 21 & 86 \\
\hline $\begin{array}{l}\text { Reddish-brown clayey sand. Fine to coarse subangular sand. } \\
\text { Reddish-yellow clay and white coarse subangular }\end{array}$ & 21 & 107 \\
\hline sand and granules of quartz. & 25 & 132 \\
\hline White to milky fine to coarse subangular sand. Trace of & & \\
\hline glauconite. & 21 & 153 \\
\hline White, fine and medium subangular sand. & 23 & 176 \\
\hline White and milky fine to coarse subangular glauconitic sand. & 21 & 197 \\
\hline White and milky fine to coarse subangular glauconitic sand. & 22 & 219 \\
\hline Greenish-white coarse subangular glauconitic sand. & 24 & 243 \\
\hline Gray, hard arnaceous limestone, Glauconitic. & 10 & 253 \\
\hline Gray, glauconitic sandy clay. & 12 & 265 \\
\hline $\begin{array}{l}\text { Gray, very fine micaceous sandy clay which contains } \\
\text { glauconite granules. }\end{array}$ & 24 & 289 \\
\hline Gray, very fine micaceous sandy clay. Trace of glauconite. & 22 & 311 \\
\hline Gray, very fine micaceous sandy clay. Trace of glauconite. & 21 & 332 \\
\hline Gray, very fine micaceous sandy clay. Trace of glauconite. & 21 & 353 \\
\hline $\begin{array}{l}\text { Gray, very fine micaceous sandy clay. Trace of glauconite. } \\
\text { Greenish-white medium grained glauconitic subangular quartz }\end{array}$ & 13 & 366 \\
\hline grains. & 20 & 386 \\
\hline Greenish-white medium-grained glauconitic subangular quartz. & 15 & 401 \\
\hline Greenish-white medium-grained glauconitic subangular quartz. & 32 & 433 \\
\hline $\begin{array}{l}\text { Milky and buff white fine, medium, and coarse subangular } \\
\text { quartz. Trace of gray clay. }\end{array}$ & 7 & 440 \\
\hline $\begin{array}{l}\text { Yellow, gray, and orange mottled clay with buff white fine } \\
\text { to coarse subangular quartz. }\end{array}$ & 23 & 463 \\
\hline $\begin{array}{l}\text { Yellow, gray, and orange mottled clay with buff white fine } \\
\text { to coarse subangular quartz. }\end{array}$ & 21 & 484 \\
\hline Greenish-white fine to coarse subangular quartz. & & \\
\hline Scattered particles of limey material. & 19 & 503 \\
\hline $\begin{array}{l}\text { Light tan-gray limey material and yellow fine and medium } \\
\text { subangular slightly glauconitic sand. }\end{array}$ & 26 & 529 \\
\hline Yellow fine, medium and coarse subangular, slightly & & \\
\hline glauconitic sand. Trace of tan limey material. & 23 & 552 \\
\hline Buff white limestone. Trace of fine sand. & 22 & 574 \\
\hline Buff white limestone. Trace of fine sand. & 21 & 595 \\
\hline Buff white limestone. Trace of fine sand. & 20 & 615 \\
\hline Buff white sandy limestone. & 23 & 638 \\
\hline Milky and white medium grained subangular quartz. & 21 & 659 \\
\hline Milky and white medium grained subangular quartz. & 13 & 672 \\
\hline
\end{tabular}


Table 2.--Sample logs of wells in the Fort Rucker area--Continued

\section{We11 123}

Owner: Town of Coffee Springs - Well 2 Driller: Emmett Hughes Drilling Co.

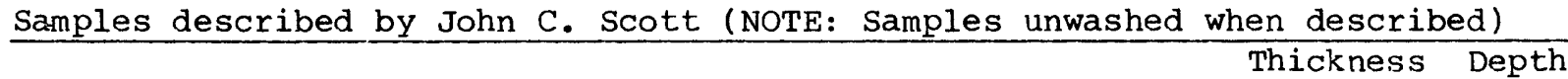

(ft) (ft)

No samples

130

Sand, yellowish-gray, fine to very coarse, loosely calcareous cemented fossiliferous, shell

fragments common.

Sand, yellowish-gray, fine to medium, calcareous, fossiliferous.

No samples.

Sand, light gray, fine, sparsely glauconitic.

Sand, light gray, medium, glauconitic; shell fragments rare.

Sand, light gray, fine to medium, sparsely glauconitic.

Sand, light gray, fine to coarse, glauconitic, shell fragments rare.

Sand, very light gray, fine to coarse, glauconitic.

Sand, light gray, fine to coarse, glauconitic, fossiliferous; shell fragments common; medium gray silty clay, rare.

Sand, medium gray, fine to medium, calcareous, finely glauconitic, fossiliferous.

Sand, light gray, fine to medium, calcareous, finely glauconitic, fossiliferous.

Sand, light gray, fine to medium, calcareous, sparsely glauconitic.

Tallahatta (?) Formation

Sand, medium gray, fine calcareous, clayey, glauconitic, sparsely micaceous, fossiliferous.

Sand, medium light gray, fine to medium, calcareous, glauconitic, sparsely fossiliferous.

Sand, medium gray, fine, very glauconitic (fine grained glauconite).

Clay, medium gray, finely sandy, calcareous, very glauconitic, fossiliferous.

Bashi Marl Member (of some authors)

Sand, medium gray, medium to coarse, calcareous, very glauconitic, fossiliferous.

Tuscahoma (?) Sand

Clay, medium dark gray, very finely sandy, calcareous, finely glauconitic, fossiliferous.

Sand, medium gray, fine to medium, glauconitic, sparsely, fossiliferous.

Clay, medium gray, silty, sparsely, glauconitic. 
Table 2.--Sample logs of wells in the Fort Rucker area--Continued

\section{Well 123}

\section{Thickness Depth}

Tuscahoma Sand

Sand, medium gray, medium to coarse silty, glauconitic, slightly ferruginous.

Clay, medium gray, silty, sparsely glauconitic, sparsely micaceous.

$30 \quad 630$

Clay, medium gray, silty, finely sandy, sparsely glauconitic and micaceous.

$40 \quad 670$

Sand, medium light gray, medium to coarse, very glauconitic.

Nanafalia (?) Formation

Sand, light gray, fine to medium, finely glauconitic.

\begin{tabular}{ll}
10 & 730 \\
10 & 740 \\
10 & 750 \\
20 & 770 \\
10 & 780 \\
10 & 790 \\
\hline
\end{tabular}

Sand, medium gray, medium to coarse, glauconitic, fossiliferous.

Sand, medium gray, fine, silty, glauconitic, slightly ferruginous.

Sand, light gray, fine to medium, finely glauconitic, slightly ferruginous.

Sand, medium light gray, medium to coarse, very calcareous, sparsely glauconitic; very pale orange limestone. 
Table 3.--Driller's logs of wells in the Fort Rucker area

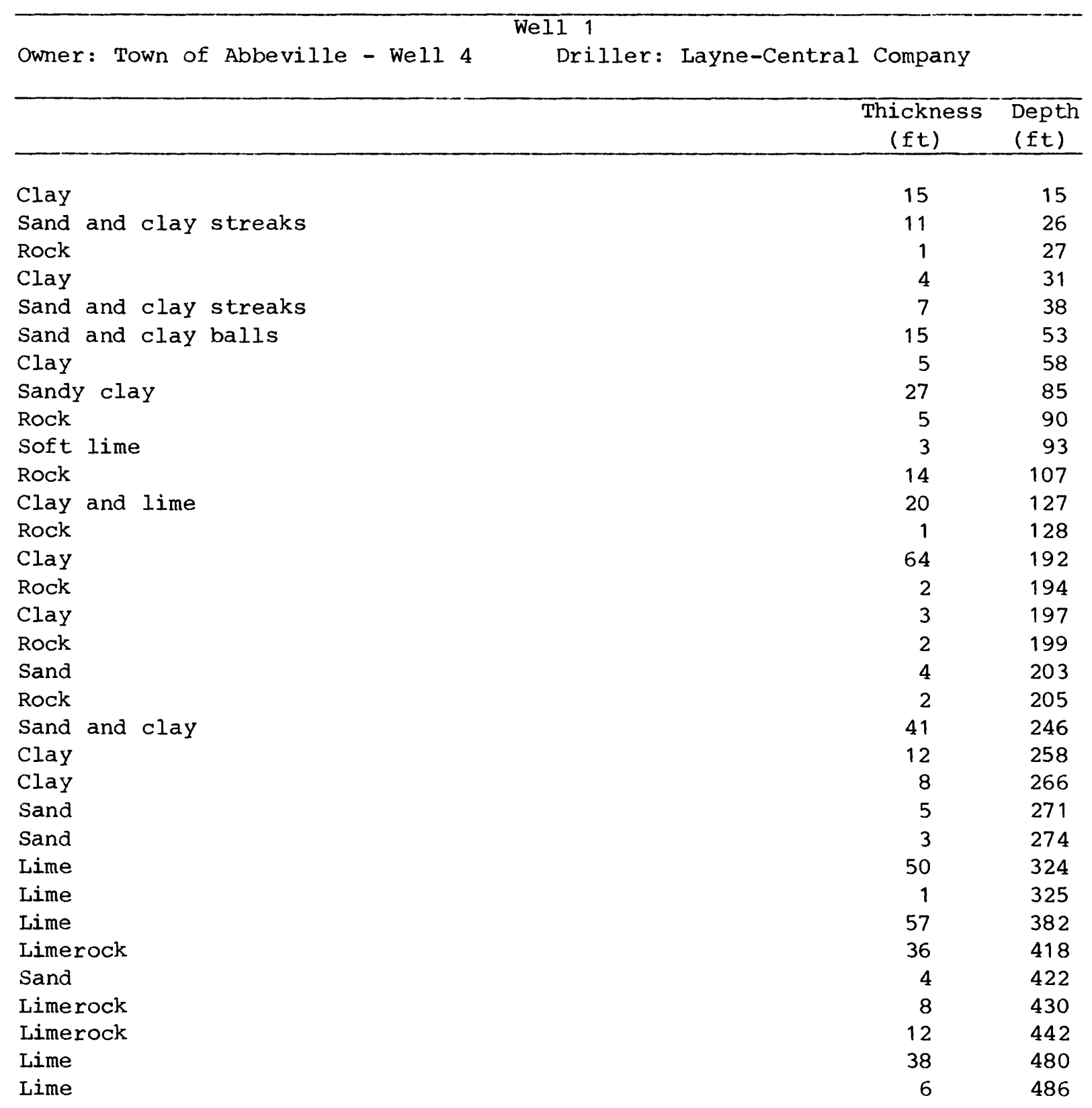


Table 3.--Driller's logs of wells in the Fort Rucker area--Continued

\begin{tabular}{|c|c|c|c|}
\hline \multirow[t]{2}{*}{ Town of Abbeville } & \multicolumn{2}{|l|}{ Well 2} & \multirow[b]{2}{*}{$\begin{array}{l}\text { Depth } \\
(\mathrm{ft})\end{array}$} \\
\hline & & $\begin{array}{l}\text { Thickness } \\
(\mathrm{ft})\end{array}$ & \\
\hline Sandy clay & & 23 & 23 \\
\hline Sand & & 8 & 31 \\
\hline Hard clay & & 16 & 47 \\
\hline Sand & & 21 & 68 \\
\hline Clay and sand streaks & & 15 & 83 \\
\hline Clay & & 15 & 98 \\
\hline Rock & & 1 & 99 \\
\hline Clay & & 1 & 100 \\
\hline Rock & & 4 & 104 \\
\hline Limes tone & & 61 & 165 \\
\hline Hard shale & & 42 & 207 \\
\hline Rock & & 1 & 208 \\
\hline Shale & & 2 & 210 \\
\hline Rock & & 1 & 211 \\
\hline Hard shale & & 10 & 221 \\
\hline Sand & & 5 & 226 \\
\hline Shale & & 12 & 238 \\
\hline Red sandy, draggy & & 10 & 248 \\
\hline Gray clay streaks lime rock & & 85 & 333 \\
\hline Soft gray lime rock & & 56 & 389 \\
\hline Hard lime rock & & 33 & 422 \\
\hline Hard lime rock & & 73 & 495 \\
\hline
\end{tabular}


Table 3.--Driller's logs of wells in the Fort Rucker area--Continued

\begin{tabular}{|c|c|c|}
\hline Owner: Town of Abbeville - Well 5 & Layne-Central Company & \\
\hline & $\begin{array}{l}\text { Thickness } \\
\text { (ft) }\end{array}$ & $\begin{array}{l}\text { Depth } \\
(\mathrm{ft})\end{array}$ \\
\hline Red clay & 10 & 10 \\
\hline Red clay and sand streaks & 9 & 19 \\
\hline Red sand with clay streaks & 35 & 54 \\
\hline Yellow sandy clay & 18 & 72 \\
\hline Clay & 12 & 84 \\
\hline Rock & 1 & 85 \\
\hline Clay and lime rock streaks & 24 & 109 \\
\hline Sandy clay & 13 & 122 \\
\hline Soft black shale & 29 & 151 \\
\hline Blue clay & 67 & 218 \\
\hline Sand & 18 & 236 \\
\hline Blue sand and soft shale & 21 & 257 \\
\hline Blue clay and lime rock streaks & 33 & 290 \\
\hline Packed sand & 27 & 317 \\
\hline Clay and blue shale & 2 & 319 \\
\hline Packed sand with rock breaks & 30 & 349 \\
\hline Clay and shale & 3 & 352 \\
\hline Hard white lime rock & 168 & 520 \\
\hline Clay & 1 & 521 \\
\hline Hard and soft lime with sand and clay & 11 & 532 \\
\hline Lime rock with blue clay & 48 & 580 \\
\hline Packed fine sand with lime streaks & 166 & 746 \\
\hline
\end{tabular}


Table 3.--Driller's logs of wells in the Fort Rucker area--Continued

\begin{tabular}{|c|c|c|c|}
\hline \multirow[b]{2}{*}{ Owner: Town of Abbeville } & \multicolumn{2}{|l|}{ Well 4} & \multirow[b]{3}{*}{$\begin{array}{l}\text { Depth } \\
\text { (ft) }\end{array}$} \\
\hline & - We11 3 Driller: & Layne-Central Company & \\
\hline & & $\begin{array}{l}\text { Thickness } \\
(\mathrm{ft})\end{array}$ & \\
\hline Red sandy clay & & 22 & 22 \\
\hline Fine sand & & 13 & 35 \\
\hline Clay & & 9 & 44 \\
\hline Rock & & 2 & 46 \\
\hline Clay & & 14 & 60 \\
\hline Clay & & 6 & 66 \\
\hline Fine sand & & 5 & 71 \\
\hline Clay & & 10 & 81 \\
\hline Sand & & 2 & 83 \\
\hline Clay & & 7 & 90 \\
\hline Rock & & 1 & 91 \\
\hline Clay & & 5 & 96 \\
\hline Rock & & 1 & 97 \\
\hline Clay & & 1 & 98 \\
\hline Rock & & 1 & 99 \\
\hline Sandy shale & & 10 & 109 \\
\hline Rock & & 2 & 111 \\
\hline Shale & & 22 & 133 \\
\hline Sandy shale & & 22 & 155 \\
\hline Shale & & 66 & 221 \\
\hline Rock and soft streaks & & 7 & 228 \\
\hline Coarse green sand & & 14 & 242 \\
\hline Coarse green sand & & 6 & 248 \\
\hline Shale & & 4 & 252 \\
\hline Rock & & 4 & 256 \\
\hline Sandy shale & & 16 & 272 \\
\hline Rock & & 2 & 274 \\
\hline Sandy shale & & 12 & 286 \\
\hline Rock & & 1 & 287 \\
\hline Hard shale & & 13 & 300 \\
\hline Coarse sand & & 8 & 308 \\
\hline Coarse sand & & 23 & 331 \\
\hline Shale & & 11 & 342 \\
\hline Sand, fine & & 12 & 354 \\
\hline Sand & & 23 & 377 \\
\hline Sand and clay streaks & & 22 & 399 \\
\hline Sand and clay streaks & & 12 & 411 \\
\hline Limerock & & 134 & 545 \\
\hline
\end{tabular}


Table 3.--Driller's logs of wells in the Fort Rucker area--Continued

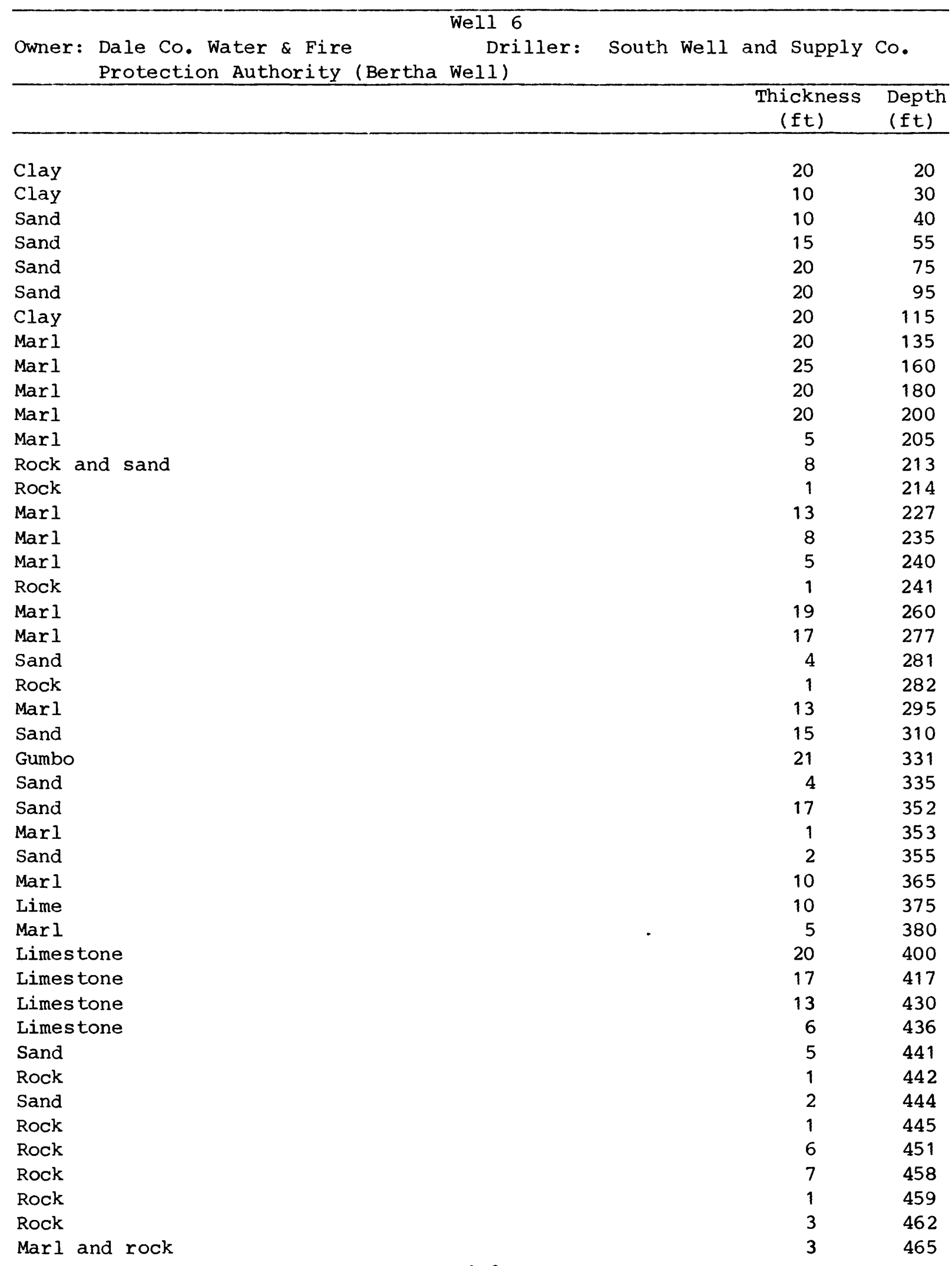


Table 3.--Driller's logs of wells in the Fort Rucker area--Continued

\begin{tabular}{|c|c|c|}
\hline & $\begin{array}{l}\text { Thickness } \\
\text { (ft) }\end{array}$ & $\begin{array}{l}\text { Depth } \\
\text { (ft) }\end{array}$ \\
\hline Rock and marl & 2 & 467 \\
\hline Marl & 1 & 468 \\
\hline Rock & 2 & 470 \\
\hline Marl and rock & 5 & 475 \\
\hline Rock & 2 & 477 \\
\hline Rock and marl & 13 & 490 \\
\hline Rock & 6 & 496 \\
\hline Rock & 2 & 498 \\
\hline Marl & 2 & 500 \\
\hline Rock & 9 & 509 \\
\hline Marl & 2 & 511 \\
\hline Rock & 3 & 514 \\
\hline Marl & 11 & 525 \\
\hline Rock & 1 & 526 \\
\hline Marl & 5 & 531 \\
\hline Rock & 1 & 532 \\
\hline Rock & 3 & 535 \\
\hline Rock & 1 & 536 \\
\hline Marl & 5 & 541 \\
\hline Rock & 1 & 542 \\
\hline Marl & 5 & 547 \\
\hline Rock & 1 & 548 \\
\hline Marl & 3 & 551 \\
\hline Marl & 9 & 560 \\
\hline Marl & 5 & 565 \\
\hline Rock & 15 & 580 \\
\hline Sand & 21 & 601 \\
\hline Marl & 14 & 615 \\
\hline Rock & 2 & 617 \\
\hline Rock & 1 & 618 \\
\hline Marl & 7 & 625 \\
\hline Marl & 1 & 626 \\
\hline Rock & 1 & 627 \\
\hline Rock and sand & 15 & 642 \\
\hline Sand & 3 & 645 \\
\hline Rock and sands tone & 4 & 649 \\
\hline Sand & 2 & 651 \\
\hline Rock and sand & 6 & 657 \\
\hline Sand & 5 & 662 \\
\hline Rock and sand & 8 & 670 \\
\hline Sand & 5 & 675 \\
\hline Rock and sand & 9 & 684 \\
\hline Sand & 3 & 687 \\
\hline Rock & 2 & 689 \\
\hline Sand & 2 & 691 \\
\hline Rock & 1 & 692 \\
\hline
\end{tabular}


Table 3.--Driller's logs of wells in the Fort Rucker area--Continued

We11 6

\begin{tabular}{rr}
$\begin{array}{c}\text { Thickness } \\
\text { (ft) }\end{array}$ & $\begin{array}{l}\text { Depth } \\
\text { (ft) }\end{array}$ \\
\hline 3 & 695 \\
6 & 701 \\
4 & 705 \\
1 & 706 \\
9 & 715 \\
10 & 725 \\
1 & 726 \\
5 & 731 \\
14 & 745 \\
10 & 755 \\
10 & 765 \\
1 & 766 \\
1 & 767
\end{tabular}

Sand

Rock and sand

Sand

Rock

Sandstone

Sands tone

Rock

Sand

Rock and sand

Sand

Rock and sand

Rock

Marl

6

767 
Table 3.--Driller's logs of wells in the Fort Rucker area--Continued

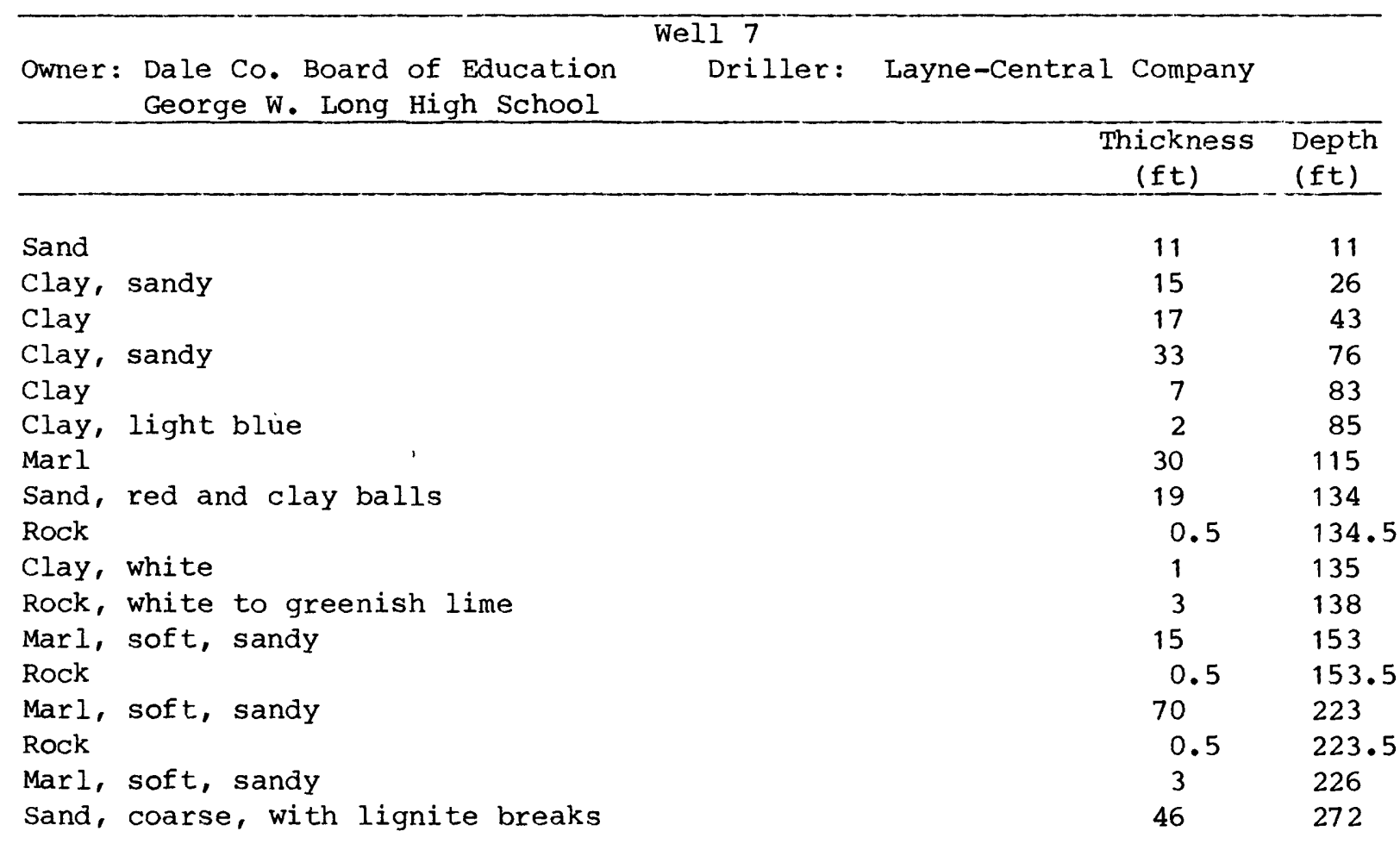


Table 3.--Driller's logs of wells in the Fort Rucker area--Continued

\begin{tabular}{|c|c|c|c|}
\hline Owner: Town of Ariton & 1111 & Taune-Central Comnany & \\
\hline & & $\begin{array}{l}\text { Thickness } \\
\text { (ft) }\end{array}$ & $\begin{array}{l}\text { Depth } \\
\text { (ft) }\end{array}$ \\
\hline Red clay & & 10 & 10 \\
\hline Sandy clay & & 15 & 25 \\
\hline Blue sandy clay & & 16 & 41 \\
\hline Hard lime rock & & 2 & 43 \\
\hline Shale & & 24 & 67 \\
\hline Red sandy clay & & 42 & 109 \\
\hline Black clay & & 27 & 136 \\
\hline Black clay & & 5 & 141 \\
\hline Sand & & 11 & 152 \\
\hline Sand and clay & & 22 & 174 \\
\hline Clay & & 8 & 182 \\
\hline Clay & & 5 & 187 \\
\hline Clay with rock streaks & & 6 & 193 \\
\hline Clay shells & & 12 & 205 \\
\hline Clay shells & & 11 & 216 \\
\hline Clay, rock and sand streaks & & 12 & 228 \\
\hline Clay & & 17 & 245 \\
\hline Clay and shell & & 6 & 251 \\
\hline Sandy clay and shells & & 8 & 259 \\
\hline Sand & & 14 & 273 \\
\hline Shale & & 11 & 284 \\
\hline Rock & & 1 & 285 \\
\hline Shale & & 10 & 295 \\
\hline Shale & & 6 & 301 \\
\hline Lime rock & & 9 & 310 \\
\hline Lime and clay & & 8 & 318 \\
\hline Lime rock - small clay streaks & & 22 & 340 \\
\hline Lime rock & & 22 & 362 \\
\hline Lime rock & & 17 & 379 \\
\hline Sand & & 6 & 385 \\
\hline Sand & & 2 & 387 \\
\hline Lime and sand & & 21 & 408 \\
\hline Sand and lime & & 23 & 431 \\
\hline Sand and lime & & 13 & 444 \\
\hline Hard lime rock & & 9 & 453 \\
\hline Hard lime rock & & 1 & 454 \\
\hline Sand and clay lime breaks & & 21 & 475 \\
\hline Sand and clay lime breaks & & 23 & 498 \\
\hline Rock & & 1 & 499 \\
\hline Sand and clay lime breaks & & 21 & 520 \\
\hline Sand and clay lime breaks & & 10 & 530 \\
\hline Rock & & 1 & 531 \\
\hline Sand and clay lime breaks & & 11 & 542 \\
\hline Sand and clay lime breaks & & 22 & 564 \\
\hline Sand and shale, rock breaks hard & & 23 & 587 \\
\hline Sand and shale, rock breaks hard & & 23 & 610 \\
\hline
\end{tabular}


Table 3.--Driller's logs of wells in the Fort Rucker area--Continued

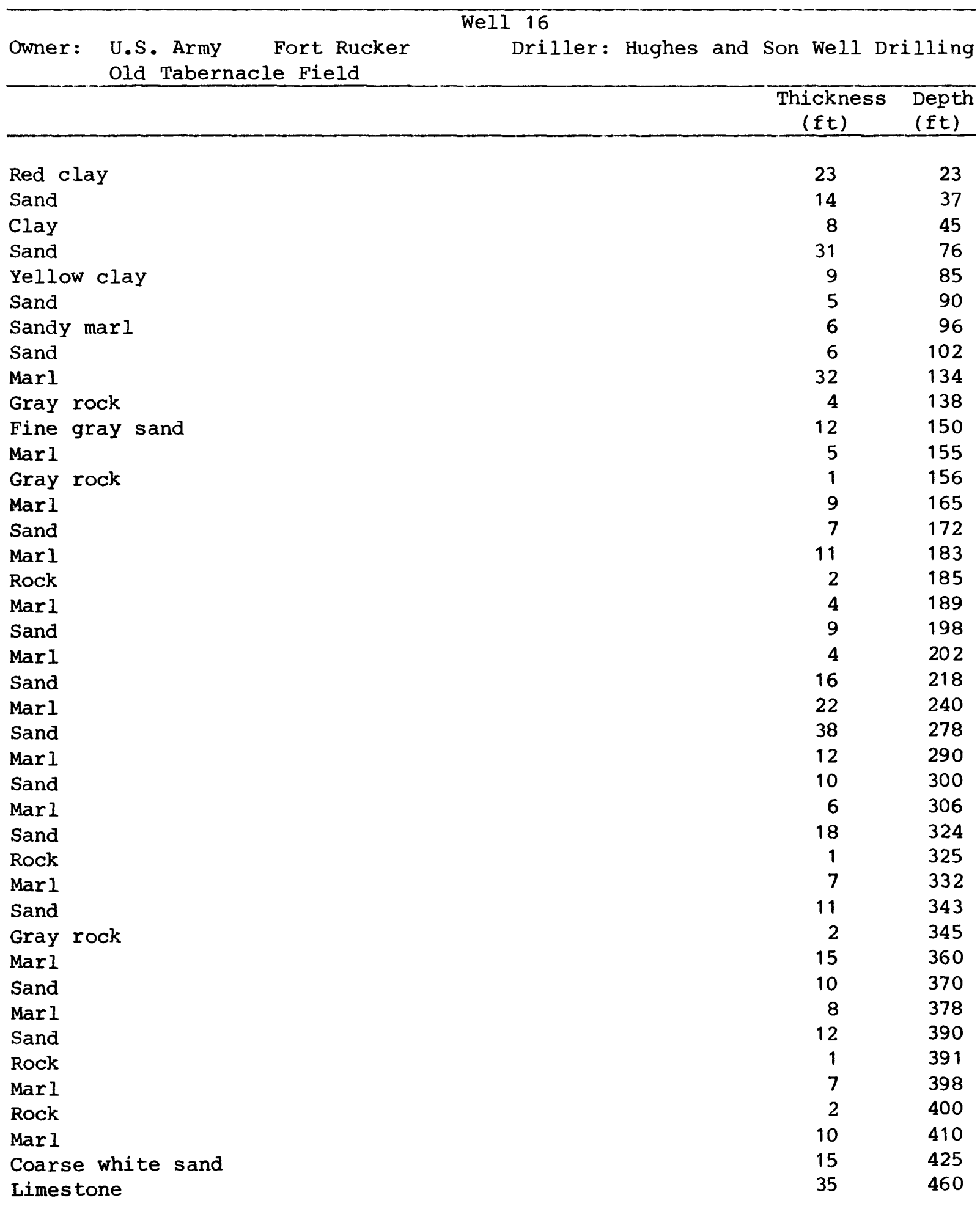


Table 3.--Driller's logs of wells in the Fort Rucker area--Continued

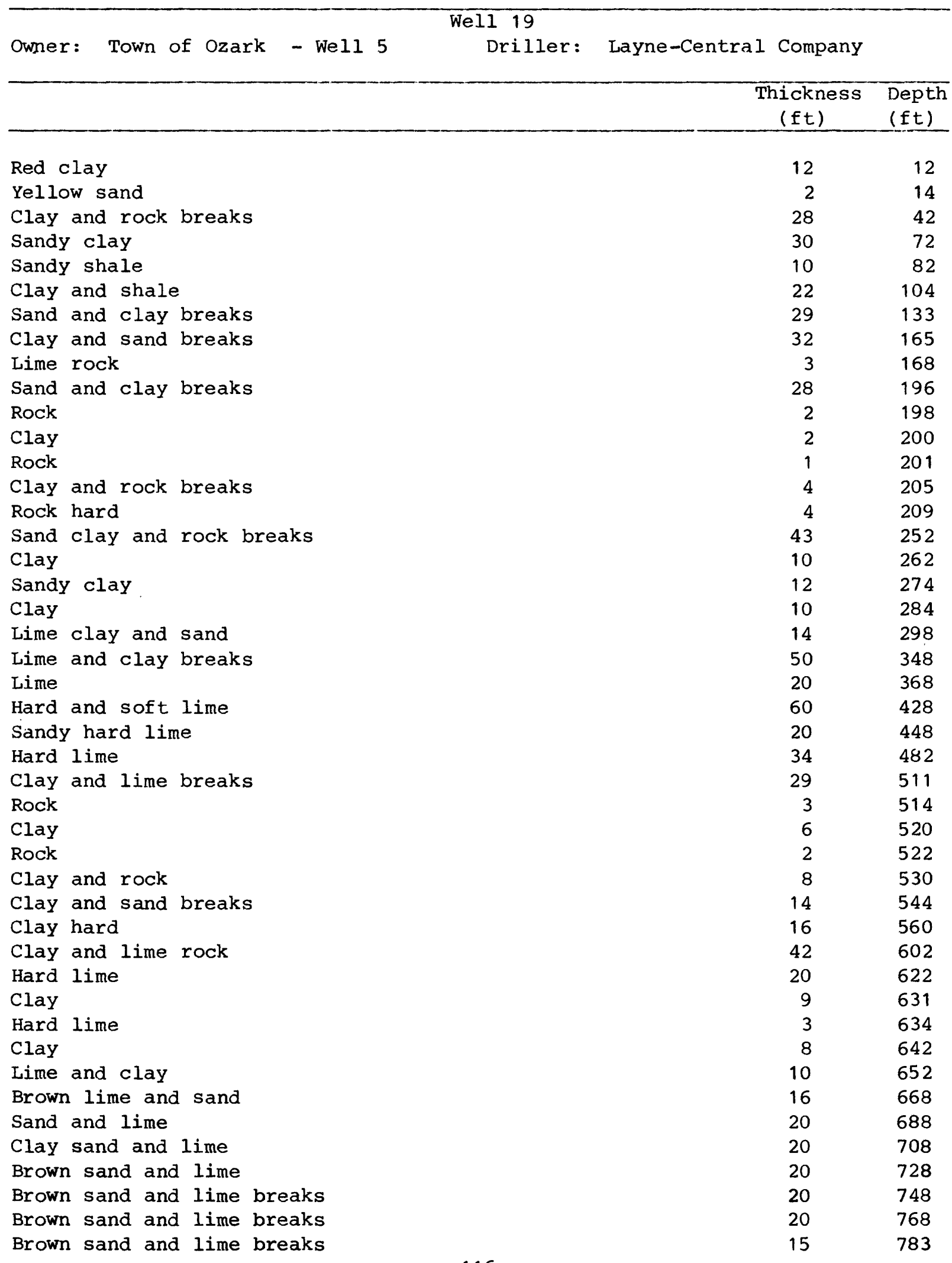


Table 3.--Driller's logs of wells in the Fort Rucker area--Continued

Well 19

Thickness Depth

Lime clay and sand breaks $(\mathrm{ft})$

Lime clay and sand breaks

\section{5}

12

788

Sand

8

14

29

7

Hard clay

Sandy clay

50

800

808

822

851

858

Hard blue clay

908 
Table 3.--Driller's logs of wells in the Fort Rucker area--Continued

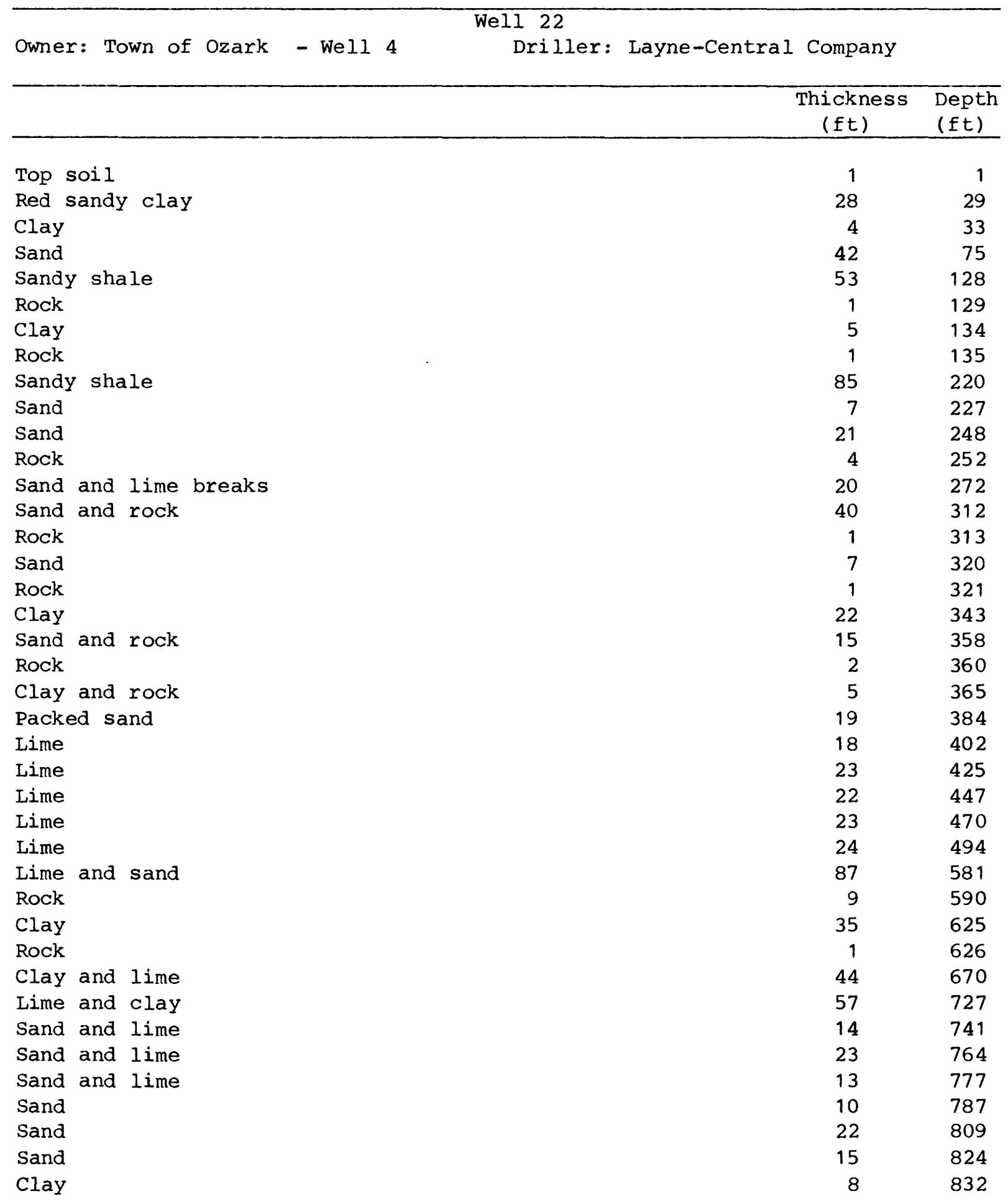


Table 3.--Driller's logs of wells in the Fort Rucker area--Continued

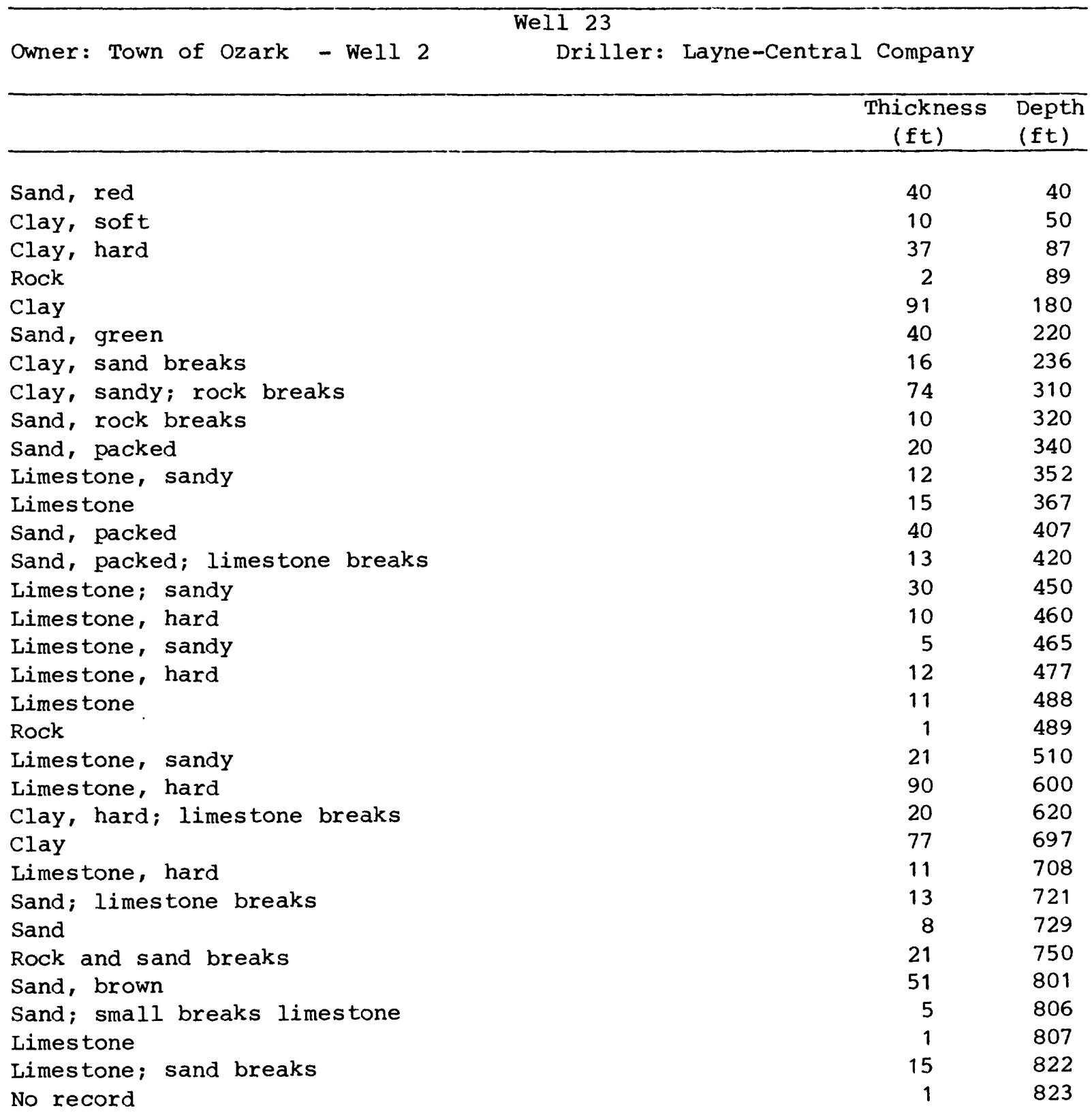


Table 3.--Driller's logs of wells in the Fort Rucker area--Continued

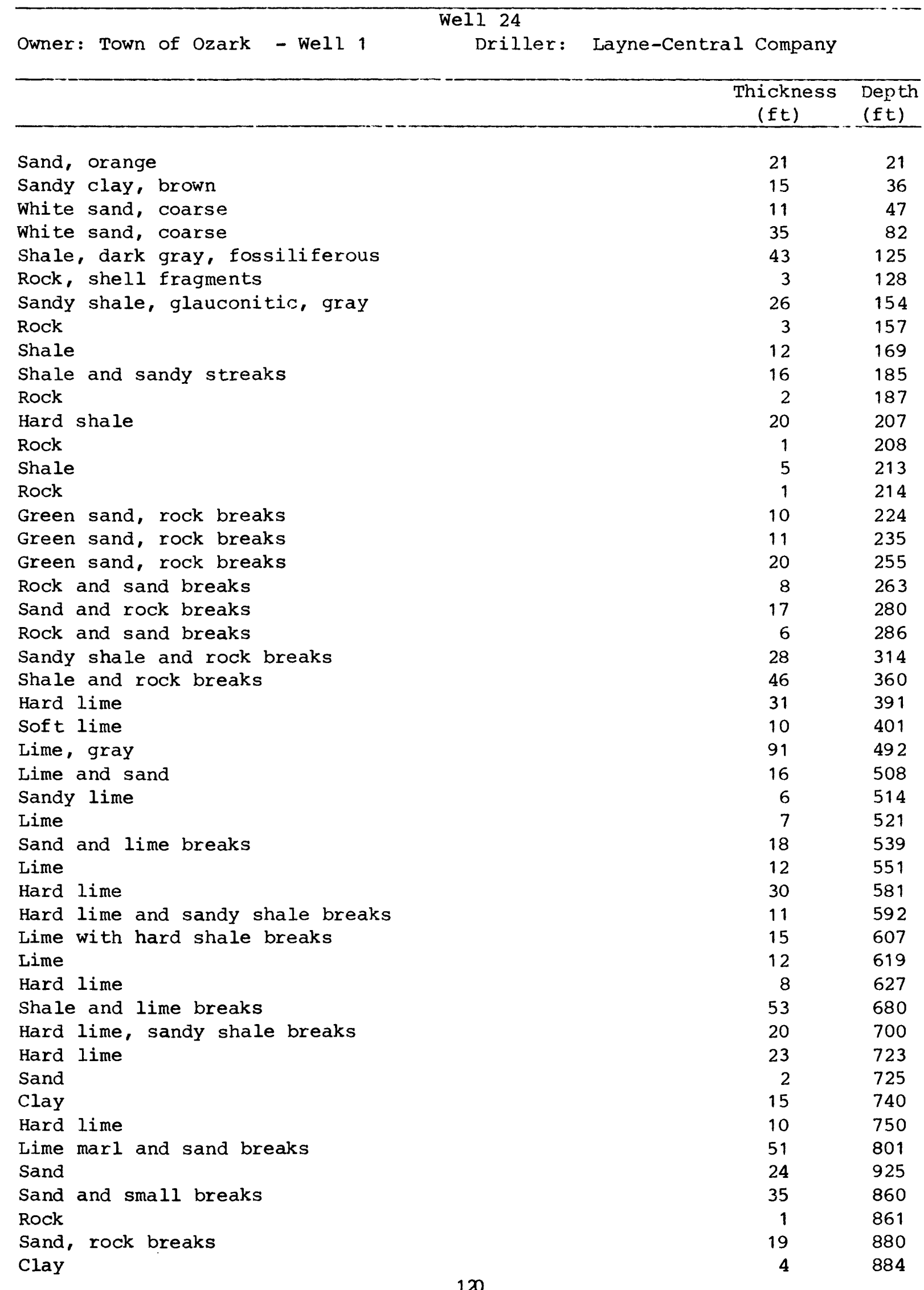


Table 3.--Driller's logs of wells in the Fort Rucker area--Continued

\begin{tabular}{|c|c|c|c|}
\hline Owner: James Golden & $\begin{array}{l}\text { Well } 28 \\
\text { Driller: Smith Well and }\end{array}$ & d Supply & Company \\
\hline & & $\begin{array}{l}\text { Thickness } \\
\text { (ft) }\end{array}$ & $\begin{array}{l}\text { Depth } \\
(\mathrm{ft})\end{array}$ \\
\hline Chalk & & 15 & 15 \\
\hline Sand & & 10 & 25 \\
\hline Sand, clay & & 10 & 35 \\
\hline Clay & & 13 & 48 \\
\hline Sand & & 2 & 50 \\
\hline Red clay & & 10 & 60 \\
\hline Sand, chalk & & 10 & 70 \\
\hline Marl & & 8 & 78 \\
\hline Rock & & 1 & 79 \\
\hline Marl & & 3 & 82 \\
\hline Rock & & 1 & 83 \\
\hline Marl & & 11 & 94 \\
\hline Rock & & 1 & 95 \\
\hline Sand & & 13 & 108 \\
\hline Rock & & 1 & 109 \\
\hline Sand & & 21 & 130 \\
\hline Marl & & 20 & 150 \\
\hline Rock & & 1 & 151 \\
\hline Mar1 & & 111 & 262 \\
\hline Sand & & 4 & 266 \\
\hline Rock & & 5 & 271 \\
\hline Sand & & 1. & 272 \\
\hline Rock & & 6 & 278 \\
\hline Sand and rock & & 22 & 300 \\
\hline Rock & & 10 & 310 \\
\hline Rock and marl & & 39 & 349 \\
\hline Sand & & 3 & 352 \\
\hline Sand and marl & & 8 & 360 \\
\hline Rock & & 4 & 364 \\
\hline Sandy marl & & 6 & 370 \\
\hline Sand & & 10 & 380 \\
\hline Mar 1 & & 2 & 382 \\
\hline Limestone & & 8 & 390 \\
\hline Sand & & 10 & 400 \\
\hline Limes tone & & 100 & 500 \\
\hline Rock & & 10 & 510 \\
\hline Sand & & 10 & 520 \\
\hline Rock & & 8 & 528 \\
\hline Sand & & 2 & 530 \\
\hline Rock & & 10 & 540 \\
\hline Rock and clay & & 20 & 560 \\
\hline
\end{tabular}


Table 3.--Driller's logs of wells in the Fort Rucker area--Continued

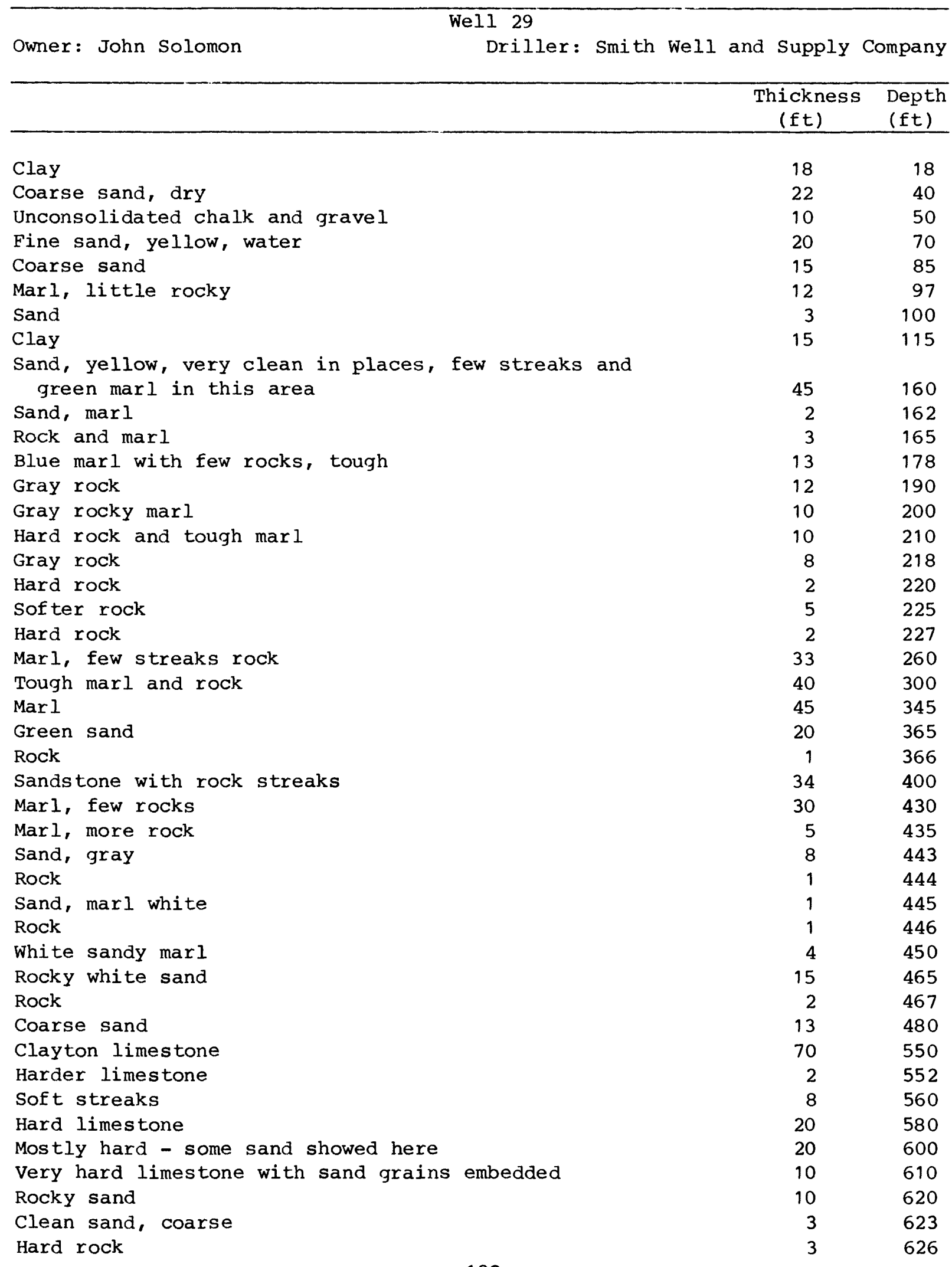


Table 3.--Driller's logs of wells in the Fort Rucker area--Continued

Well 29

$\begin{array}{cc}\begin{array}{c}\text { Thickness } \\ (f t)\end{array} & \begin{array}{l}\text { Depth } \\ (f t)\end{array} \\ 12 & 638 \\ 1 & 639 \\ 9 & 648 \\ 1 & 649 \\ 31 & 680 \\ 10 & 690\end{array}$

Clean sand and rock

Hard rock

Sand, clean

Hard rock

Clean sand, medium coarse

sand, not so clean

Little marl 
Table 3.--Driller's logs of wells in the Fort Rucker area--Continued

\begin{tabular}{lccc}
\hline Owner: Town of Newville $\begin{array}{l}\text { Well } 2 \\
\text { Driller: }\end{array}$ & $\begin{array}{r}\text { Thickness } \\
\text { (ft) }\end{array}$ & $\begin{array}{c}\text { Depth } \\
\text { (ft) }\end{array}$ \\
\hline & & 10 & 10 \\
Clay & 15 & 25 \\
Sandy clay & 25 & 50 \\
Sand & 50 & 100 \\
Rock & 81 & 181 \\
Shale & 24 & 205 \\
Rock and sand & 67 & 272 \\
Shale & 28 & 300 \\
Sandy shale & 47 & 347 \\
Rocky shale with sand & 3 & 350 \\
Rock & 34 & 384 \\
Rock and shale with sand & 31 & 415 \\
Sand & 35 & 450 \\
Limey sand & 6 & 456 \\
Rock & 116 & 572
\end{tabular}


Table 3.--Driller's logs of wells in the Fort Rucker area--Continued

\begin{tabular}{|c|c|c|c|c|}
\hline Owner: U.S. Army & - Fort Rucker & $\begin{array}{l}\text { Well } 32 \\
\text { Driller: Buie Drilling }\end{array}$ & Company & \\
\hline & & & $\begin{array}{l}\text { Thickness } \\
\text { (ft) }\end{array}$ & $\begin{array}{l}\text { Depth } \\
(\mathrm{ft})\end{array}$ \\
\hline Clay & & & 20 & 20 \\
\hline Sandy clay & & & 20 & 40 \\
\hline Coarse sand & & & 60 & 100 \\
\hline Sand with rock & & & 10 & 110 \\
\hline Soft sandy rock & & & 10 & 120 \\
\hline Light blue marl & & & 30 & 150 \\
\hline Blue marl & & & 140 & 290 \\
\hline
\end{tabular}


Table 3.--Driller's logs of wells in the Fort Rucker area--Continued

Wel1 33

Owner: Faulkner Farms, Inc.

Driller: Smith Well and Supply Company

\begin{tabular}{|c|c|c|}
\hline & $\begin{array}{l}\text { Thickness } \\
\text { (ft) }\end{array}$ & $\begin{array}{l}\text { Depth } \\
\text { (ft) }\end{array}$ \\
\hline Clay & 18 & 18 \\
\hline Coarse sand & 14 & 32 \\
\hline Gravel & 6 & 38 \\
\hline Coarse sand and chalk & 20 & 58 \\
\hline Yellow sand & 22 & 80 \\
\hline Pink sand & 15 & 95 \\
\hline Marl (green) & 5 & 100 \\
\hline Sandy blue marl & 15 & 115 \\
\hline Sand & 17 & 132 \\
\hline Soft rock and sand & 15 & 147 \\
\hline Blue marl & 10 & 157 \\
\hline Black pepper sand & 3 & 160 \\
\hline Gray rock (soft) & 23 & 185 \\
\hline Hard rock & 2 & 187 \\
\hline Gray rock and sand & 10 & 197 \\
\hline Blue marl & 37 & 234 \\
\hline Sandy marl & 11 & 245 \\
\hline Rock & 1 & 246 \\
\hline Sandy marl & 11 & 257 \\
\hline Mar 1 & 15 & 272 \\
\hline Sandy marl & 16 & 288 \\
\hline Coarse green sand & 16 & 304 \\
\hline Coarse green sand, some rock scattered & 21 & 325 \\
\hline Green sand and gray rock & 14 & 339 \\
\hline Hard rock & 1 & 340 \\
\hline Gray rock and green sand & 8 & 348 \\
\hline Hard rock & 1 & 349 \\
\hline Sandy marl & 10 & 359 \\
\hline Hard rock & 1 & 360 \\
\hline Sandy marl & 10 & 370 \\
\hline Soft marl & 10 & 380 \\
\hline Rock marl & 12 & 392 \\
\hline Coarse green sand & 8 & 400 \\
\hline Rock & 8 & 408 \\
\hline Gray sand (coarse) & 17 & 425 \\
\hline White lime rock & 20 & 445 \\
\hline Pretty solid rock & 7 & 452 \\
\hline Softer rock & 28 & 480 \\
\hline More solid & 47 & 527 \\
\hline Harder & 9 & 536 \\
\hline Hard rock & 5 & 541 \\
\hline Drilled as sandstone, sampled as medium sand & 17 & 558 \\
\hline Hard rock & 2 & 560 \\
\hline Soft sand, getting coarser here & 3 & 563 \\
\hline
\end{tabular}


Table 3.--Driller's logs of wells in the Fort Rucker area--Continued

\section{Wel1 33}

Thickness

(ft)

Depth

\begin{tabular}{|c|c|c|}
\hline & $\begin{array}{l}\text { Thickness } \\
\text { (ft) }\end{array}$ & $\begin{array}{l}\text { Depth } \\
(\mathrm{ft})\end{array}$ \\
\hline Rock, hard, little softer bottom few feet & 7 & 570 \\
\hline Sand, softer, washed out, not very clean or coarse, & & \\
\hline had a soft feel, maybe a little clay & 7 & 577 \\
\hline Hard rock & 1 & 578 \\
\hline Softer rock, sampled as clean rock possibly porous, & & \\
\hline not very much sand & 6 & 584 \\
\hline Hard rock & 2 & 586 \\
\hline Softer, sampled as clean rock and sand & 14 & 600 \\
\hline Sand, mushy, some marl here, providence started here & 20 & 620 \\
\hline Rocky sand, sampled as clean sand medium & 10 & 630 \\
\hline Hard rock, sampled as clean sand medium & 2 & 632 \\
\hline Soft, sampled as clean sand medium & 1 & 633 \\
\hline Hard rock & 1 & 634 \\
\hline Softer as sandstone, sampled as clean coarse sand & 6 & 640 \\
\hline Medium hard, sampled as good clean coarse providence sand & 6 & 646 \\
\hline Hard, sampled as good clean coarse providence sand & 1 & 647 \\
\hline Medium sand, sampled as good clean coarse providence sand & 13 & 660 \\
\hline Harder, sampled as clean coarse sand, streaks of rock & 20 & 680 \\
\hline Same as above except last $2 \mathrm{ft}$ very hard, possible gumbo & & \\
\hline marl and rock & 20 & 700 \\
\hline Sand and rock & 25 & 725 \\
\hline $\operatorname{Mar} 1$ & 11 & 736 \\
\hline
\end{tabular}


Table 3.--Driller's logs of wells in the Fort Rucker area--Continued

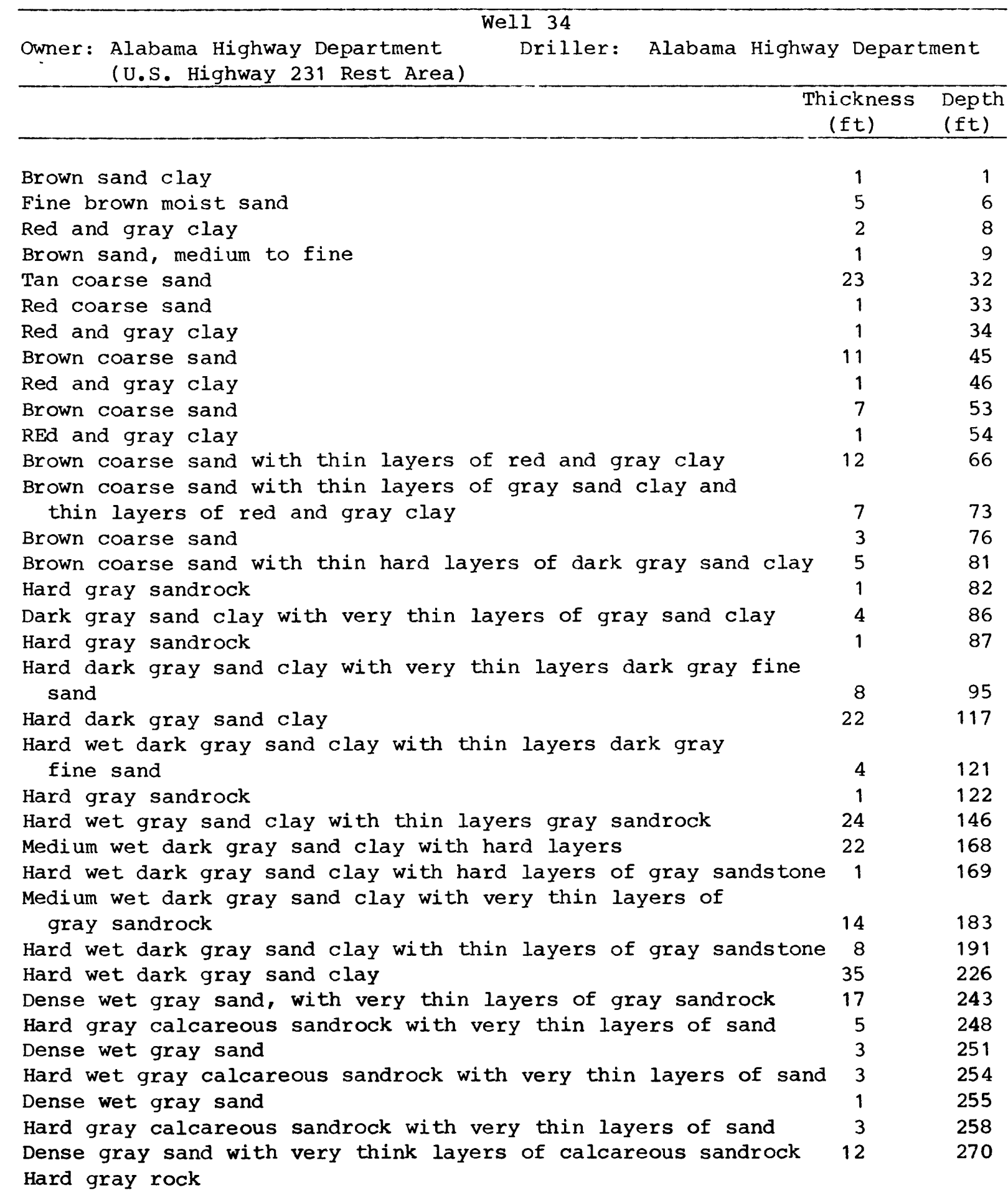


Table 3.--Driller's logs of wells in the Fort Rucker area--Continued

We11 35

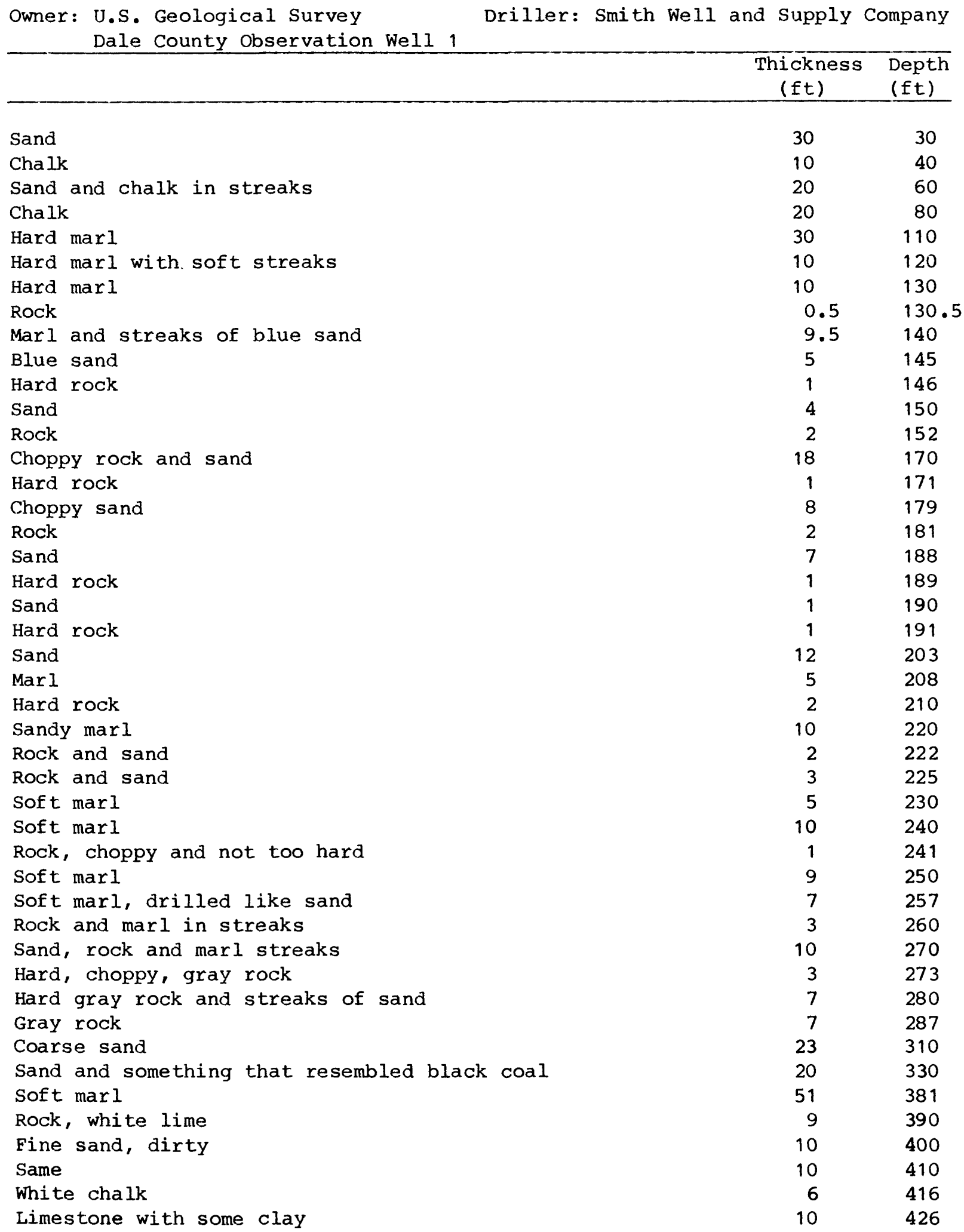


Table 3.--Driller's logs of wells in the Fort Rucker area--Continued

\begin{tabular}{|c|c|c|}
\hline & $\begin{array}{l}\text { Thickness } \\
\text { (ft) }\end{array}$ & $\begin{array}{l}\text { Depth } \\
\text { (ft) }\end{array}$ \\
\hline Limestone, harder & 7 & 433 \\
\hline Medium sand, clean & 18 & 451 \\
\hline Hard rock & 5 & 456 \\
\hline Hard rock & 3 & 459 \\
\hline Sand & 11 & 470 \\
\hline Hard rock & 1 & 471 \\
\hline Rock & 2 & 473 \\
\hline Sand & 9 & 482 \\
\hline Rock & 8 & 490 \\
\hline Rock & 6 & 496 \\
\hline Sand & 4 & 500 \\
\hline Hard rock & 10 & 510 \\
\hline Marl & 6 & 516 \\
\hline Marl with streaks of rock & 6 & 522 \\
\hline Rock and sand & 14 & 536 \\
\hline Rock & 5 & 541 \\
\hline Sand & 9 & 550 \\
\hline $\operatorname{Mar} 1$ & 1 & 551 \\
\hline Rock and sand & 5 & 556 \\
\hline
\end{tabular}


Table 3.--Driller's logs of wells in the Fort Rucker area--Continued

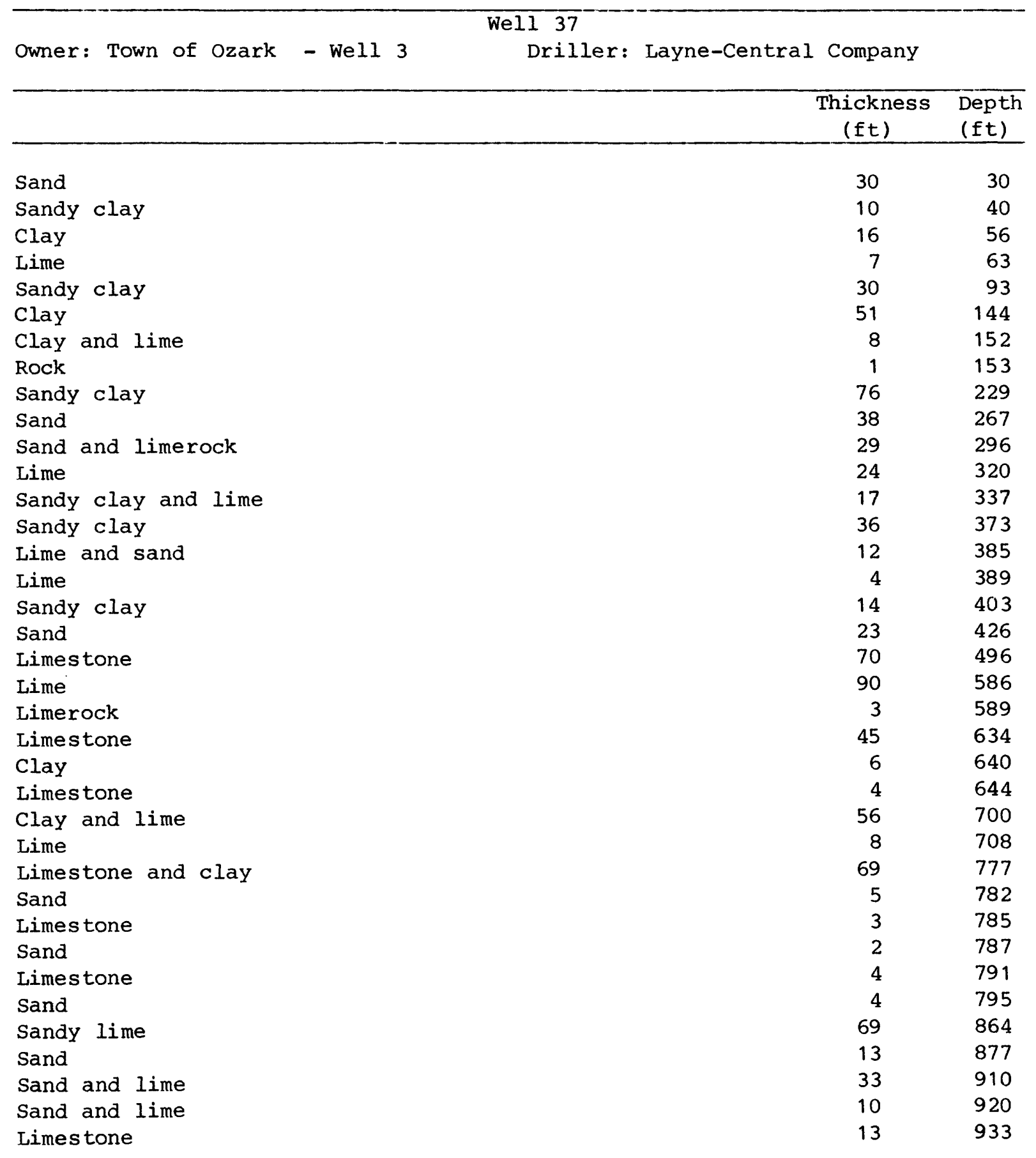


Table 3.--Driller's logs of wells in the Fort Rucker area--Continued

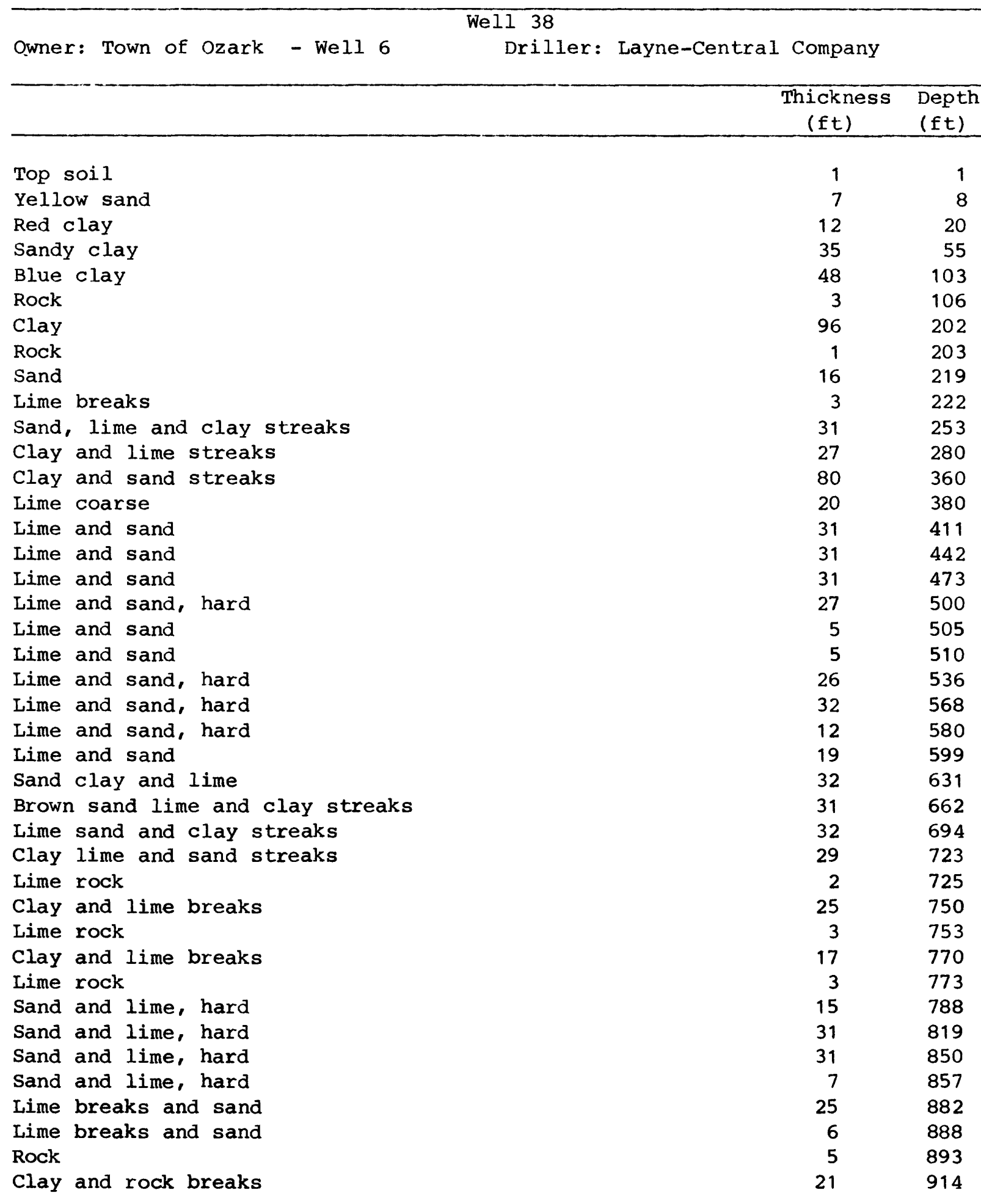


Table 3.--Driller's logs of wells in the Fort Rucker area--Continued

Wel1 42

Owner: U.S. Army - Fort Rucker

Driller: Carroll Hardware, Inc. Wildlife Area

Thickness Depth

(ft)

(ft)

Sand and clay

10

10

Sand and clay

$10 \quad 20$

Soaps tone

$10 \quad 30$

Soapstone and clay

$10 \quad 40$

Soapstone and rock

$10 \quad 50$

Soapstone and sand

$10 \quad 60$

Soaps tone

$10 \quad 70$

Dark coarse sand

Soapstone

$10 \quad 80$

Soapstone and rock

$10 \quad 90$

Soapstone and rock

$10 \quad 100$

Soapstone and rock

$10 \quad 110$

Soapstone and rock

$10 \quad 120$

Soapstone and rock

$10 \quad 130$

Soapstone and rock

$10 \quad 140$

Soapstone and rock

$10 \quad 150$

$10 \quad 160$

Soapstone and rock

$10 \quad 170$

Soapstone and rock

$10 \quad 180$

Rock

$10 \quad 190$

Rock and sand

$10 \quad 200$

Coarse sand

$10 \quad 210$

Coarse sand

$10 \quad 220$

Green sand

$10 \quad 230$

Green sand

$10 \quad 240$

Green sand

$10 \quad 250$

Green sand and shell

$10 \quad 260$


Table 3.--Driller's logs of wells in the Fort Rucker area--Continued

Well 45

Owner: Alabama National Guard

Driller: Smith Well and Supply Company

\begin{tabular}{|c|c|c|}
\hline & $\begin{array}{l}\text { Thickness } \\
\text { (ft) }\end{array}$ & $\begin{array}{l}\text { Depth } \\
\text { (ft) }\end{array}$ \\
\hline Sandy clay & 30 & 30 \\
\hline Fine sand & 7 & 37 \\
\hline Yellow clay & 15 & 52 \\
\hline Blue marl & 34 & 86 \\
\hline Rock soft & 4 & 90 \\
\hline Rock & 1.5 & 91.5 \\
\hline Marl & 1.5 & 93 \\
\hline Rock & 2 & 95 \\
\hline Marl & 33 & 128 \\
\hline Marl & 43 & 171 \\
\hline Sand & 29 & 200 \\
\hline Sand, rock streaks & 5 & 205 \\
\hline Sand & 5 & 210 \\
\hline Rock with sand breaks & 7 & 217 \\
\hline Sand & 8 & 225 \\
\hline Sand & 10 & 235 \\
\hline Rock & 1 & 236 \\
\hline Sand & 3 & 239 \\
\hline Rock & 1 & 240 \\
\hline Sand & 25 & 265 \\
\hline Rock & 1 & 266 \\
\hline Sand & 3 & 269 \\
\hline Rock & 4 & 273 \\
\hline Sand & 17 & 290 \\
\hline Marl & 3 & 293 \\
\hline Sand & 12 & 305 \\
\hline Sandy $\operatorname{mar} 1$ & 10 & 315 \\
\hline
\end{tabular}


Table 3.--Driller's logs of wells in the Fort Rucker area--Continued

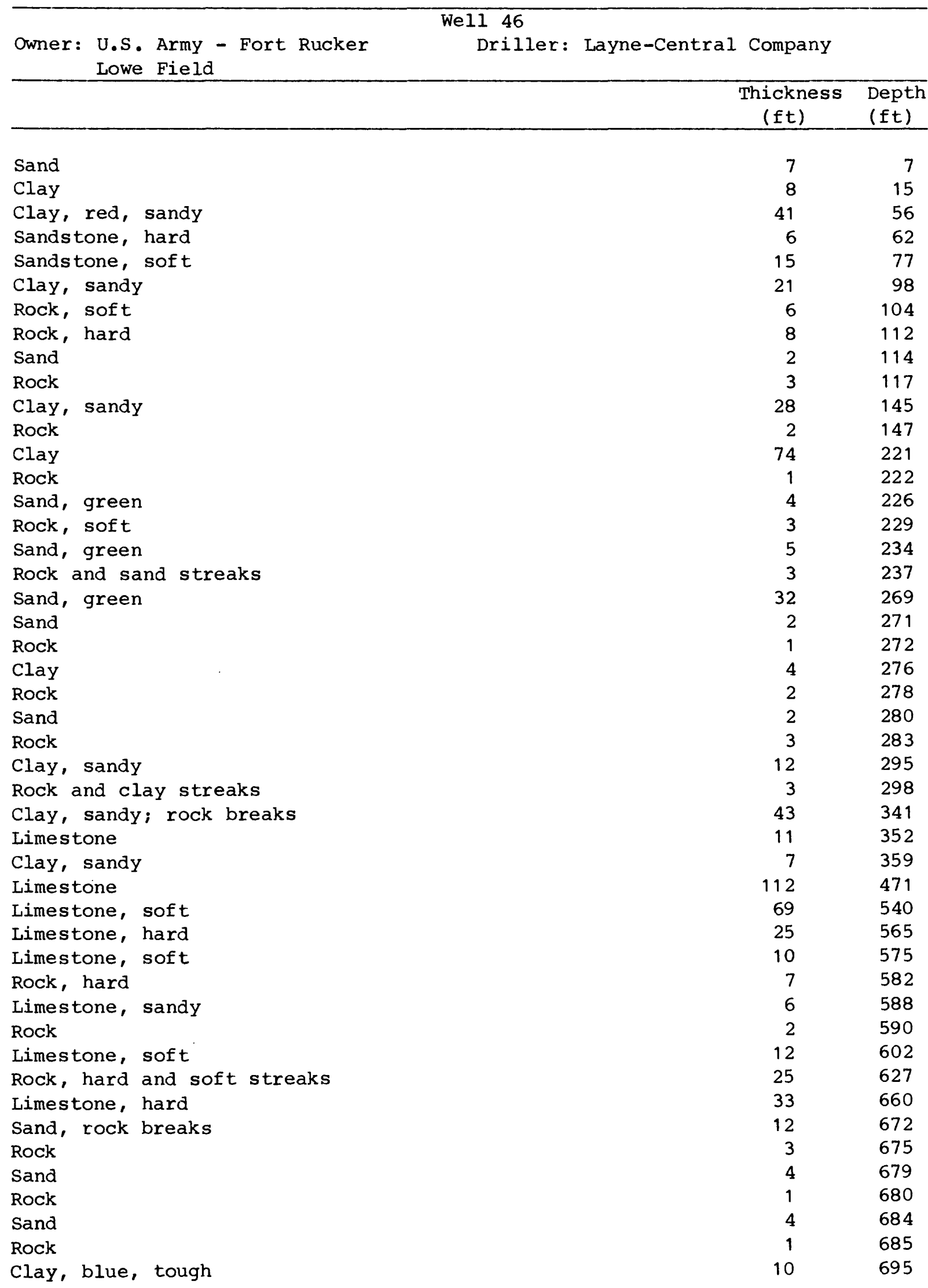


Table 3.--Driller's logs of wells in the Fort Rucker area--Continued

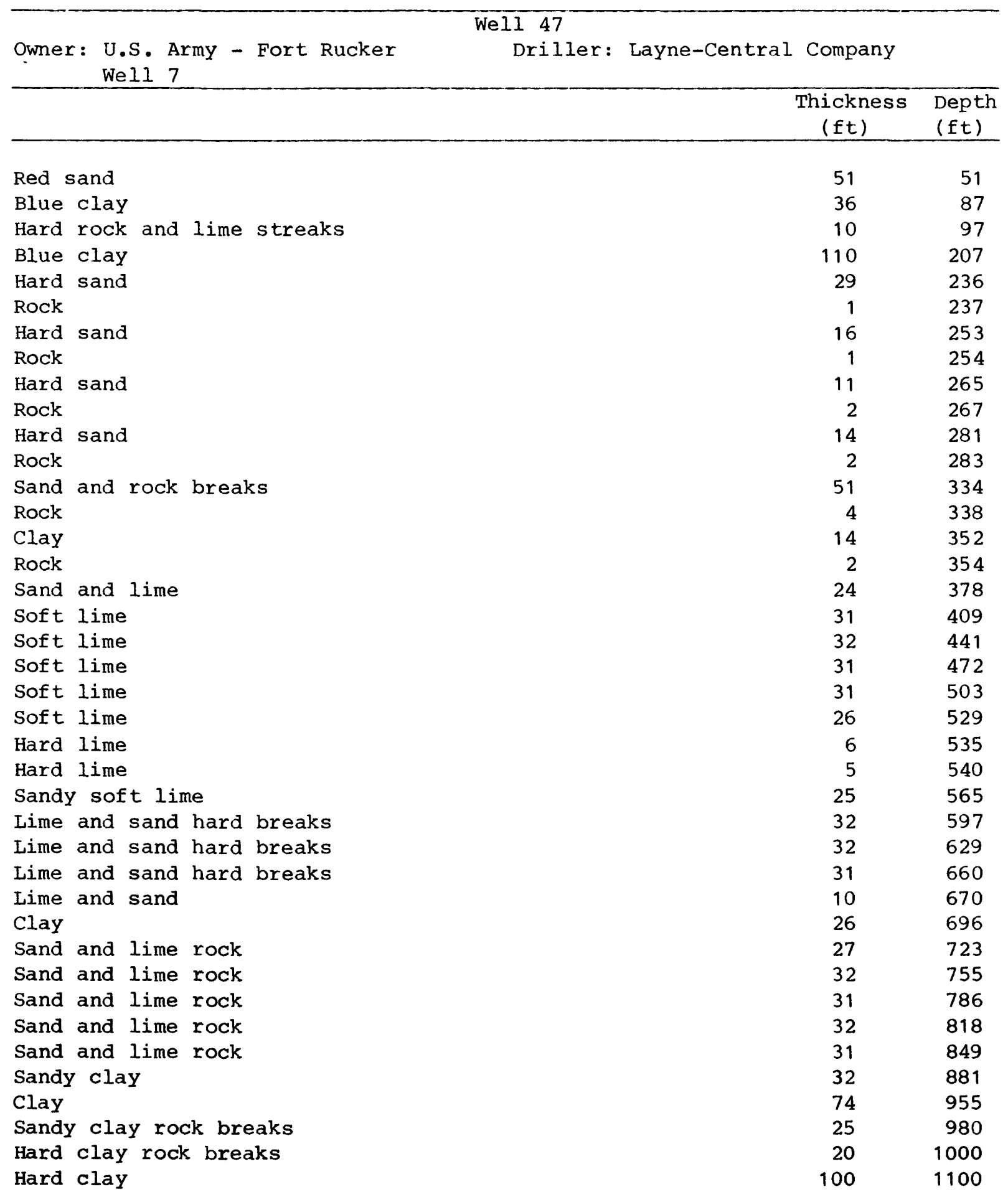


Table 3.--Driller's logs of wells in the Fort Rucker area--Continued

\begin{tabular}{|c|c|c|c|}
\hline $\begin{aligned} \text { Owner: U.S. Army - Fort Rucker } \\
\text { Shell Field }\end{aligned}$ & $\begin{array}{l}\text { Well } 49 \\
\text { Driller: Acme }\end{array}$ & Drilling Company & \\
\hline & & $\begin{array}{l}\text { Thickness } \\
(\mathrm{ft})\end{array}$ & $\begin{array}{l}\text { Depth } \\
\text { (ft) }\end{array}$ \\
\hline Sand, streaks clay & & 86 & 86 \\
\hline Clay, sandy with streaks sand & & 21 & 107 \\
\hline Marl, blue & & 14 & 121 \\
\hline Rock break & & - & - \\
\hline Shale & & 21 & 142 \\
\hline Marl, blue & & 18 & 160 \\
\hline Sand & & 5 & 165 \\
\hline Rock & & 7 & 172 \\
\hline Shale & & 37 & 209 \\
\hline Rock & & 1 & 210 \\
\hline Shale, sandy & & 102 & 312 \\
\hline Rock & & 3 & 315 \\
\hline Limestone, soft and sand & & 7 & 322 \\
\hline Rock & & 5 & 327 \\
\hline Shale, sandy & & 20 & 347 \\
\hline Shale & & 6 & 353 \\
\hline Shale, sandy & & 4 & 357 \\
\hline Sand & & 12 & 369 \\
\hline Rock & & 1 & 370 \\
\hline Shale and rocks & & 8 & 378 \\
\hline Shale & & 11 & 389 \\
\hline Rock & & 1 & 390 \\
\hline Shale & & 2 & 392 \\
\hline Rock & & 1 & 393 \\
\hline Shale and limestone & & 17 & 410 \\
\hline Rock & & 4 & 414 \\
\hline Shale and limestone & & 3 & 417 \\
\hline Rock & & 1 & 418 \\
\hline Limestone and sand & & 9 & 427 \\
\hline Rock & & 2 & 429 \\
\hline Sand and limestone & & 17 & 446 \\
\hline Rock & & 2 & 448 \\
\hline Sand and shellrock & & 27 & 475 \\
\hline Limestone, hard & & 2 & 477 \\
\hline Sand, limey, with black streaks & & 9 & 486 \\
\hline Limestone, hard & & 2 & 488 \\
\hline Sand, limey & & 2 & 490 \\
\hline Sand, packed; colors mud black & & 15 & 505 \\
\hline Rock & & 2 & 507 \\
\hline Sand, packed; colors mud black & & 18 & 525 \\
\hline Clay and limestone & & 3 & 528 \\
\hline Limestone, soft & & 4 & 532 \\
\hline Limestone, sandy & & 6 & 538 \\
\hline Rock & & 2 & 540 \\
\hline Limestone, soft & & 44 & 584 \\
\hline Rock, hard & & 3 & 587 \\
\hline Limestone & & 6 & 593 \\
\hline Limestone, hard & & 37 & 630 \\
\hline Limestone, sandy & 137 & 10 & 640 \\
\hline
\end{tabular}


Table 3.--Driller's logs of wells in the Fort Rucker area--Continued

Wel1 50

Owner: Town of New Brockton - Well 2 Driller: Layne-Central Company

\begin{tabular}{|c|c|c|}
\hline & $\begin{array}{l}\text { Thickness } \\
(\mathrm{ft})\end{array}$ & $\begin{array}{l}\text { Depth } \\
(\mathrm{ft})\end{array}$ \\
\hline Top soil & 2 & 2 \\
\hline Clay & 17 & 19 \\
\hline Sand & 7 & 26 \\
\hline Clay & 100 & 126 \\
\hline Rock & 3 & 129 \\
\hline Clay & 69 & 198 \\
\hline Sand & 6 & 204 \\
\hline Limerock & 5 & 209 \\
\hline Limerock and sand & 3 & 212 \\
\hline Clay & 112 & 324 \\
\hline Rock & 1 & 325 \\
\hline Clay & 10 & 335 \\
\hline Clay & 15 & 350 \\
\hline Lime rock & 5 & 355 \\
\hline Clay & 25 & 380 \\
\hline Clay & 22 & 402 \\
\hline Clay and limerock & 12 & 414 \\
\hline Clay & 11 & 425 \\
\hline Clay & 23 & 448 \\
\hline Clay, limerock & 22 & 470 \\
\hline Clay, limerock & 15 & 485 \\
\hline Limestone & 7 & 492 \\
\hline Limes tone & 23 & 515 \\
\hline Limes tone & 22 & 537 \\
\hline
\end{tabular}


Table 3.--Driller's logs of wells in the Fort Rucker area--Continued

Well 51

Owner: Town of New Brockton - Well 3 Driller: Layne-Central Company

\begin{tabular}{|c|c|c|}
\hline & $\begin{array}{l}\text { Thickness } \\
\text { (ft) }\end{array}$ & $\begin{array}{l}\text { Depth } \\
\text { (ft) }\end{array}$ \\
\hline Clay & 25 & 25 \\
\hline Red clay & 72 & 97 \\
\hline Blue clay & 4 & 101 \\
\hline Red clay & 15 & 116 \\
\hline Limerock & 2 & 118 \\
\hline Sand and shells & 8 & 126 \\
\hline Soapstone & 63 & 189 \\
\hline Lime & 3 & 192 \\
\hline Soapstone & 90 & 282 \\
\hline Sand & 5 & 287 \\
\hline Green sand & 16 & 303 \\
\hline Sand and pepper sand & 33 & 336 \\
\hline Rock & 2 & 338 \\
\hline Sandy clay & 21 & 359 \\
\hline Sand & 7 & 366 \\
\hline Clay & 3 & 369 \\
\hline Sand & 5 & 374 \\
\hline Cemented sand & 22 & 396 \\
\hline Sandy clay & 12 & 408 \\
\hline Sand & 17 & 425 \\
\hline Sandy clay & 4 & 429 \\
\hline Sand and clay & 20 & 449 \\
\hline Rock and sandy clay & 8 & 457 \\
\hline Sand and clay & 16 & 473 \\
\hline Clay, sand and lime & 10 & 483 \\
\hline Sand & 4 & 487 \\
\hline Sand and lime & 19 & 506 \\
\hline Sand and lime & 13 & 519 \\
\hline Rock & 2 & 521 \\
\hline Lime & 6 & 527 \\
\hline Rock & 2 & 529 \\
\hline Lime & 95 & 624 \\
\hline Lime & 2 & 626 \\
\hline Lime & 18 & 644 \\
\hline Rock & 2 & 646 \\
\hline
\end{tabular}


Table 3.--Driller's logs of wells in the Fort Rucker area--Continued

Wel1 52

Owner: Town of New Brockton - Well 1 Driller: Layne-Central Company

Thickness

Depth

(ft)

(ft)

Red clay

White clay

$26 \quad 26$

CLay

Red clay

Clay

Sands tone

Sand clay

Hard rock

Soaps tone

Sand

Clay

Rock

$54 \quad 80$

383

$39 \quad 122$

$4 \quad 126$

$2 \quad 128$

$9 \quad 137$

$1 \quad 138$

$60 \quad 198$

$6 \quad 204$

$6 \quad 210$

Hard sand

$2 \quad 212$

Soapstone

$6 \quad 218$

Rock

$29 \quad 247$

Soaps tone

Rock

13

Clay

Sands tone

1

50

2

Soaps tone

11

water-bearing sand 
Table 3.--Driller's logs of wells in the Fort Rucker area--Continued

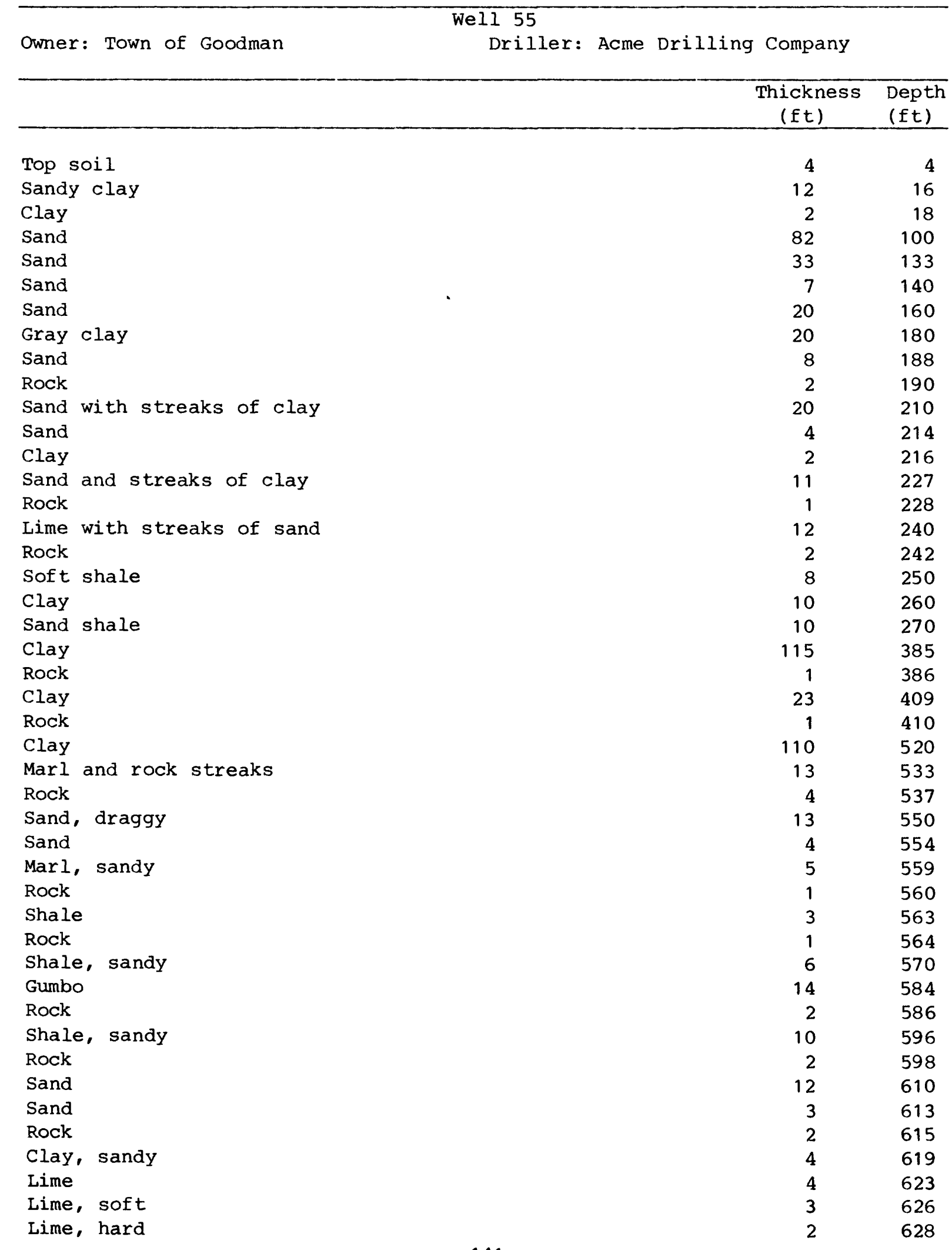


Table 3.--Driller's logs of wells in the Fort Rucker area--Continued

Well 55

Thickness

Depth

(ft)

(ft)

Sand

Rock

$4 \quad 632$

Shale, sandy

Rock

Marl

Sand

Rock

Sand

Rock

Rock

Lime, soft

$2 \quad 634$

$7 \quad 641$

$2 \quad 643$

Lime

$14 \quad 657$

$3 \quad 660$

$3 \quad 663$

$4 \quad 667$

2669

3672

$3-675$

Lime

$85 \quad 760$

Lime, hard

85

845

clay

$60 \quad 905$

5910 
Table 3.--Driller's logs of wells in the Fort Rucker area--Continued

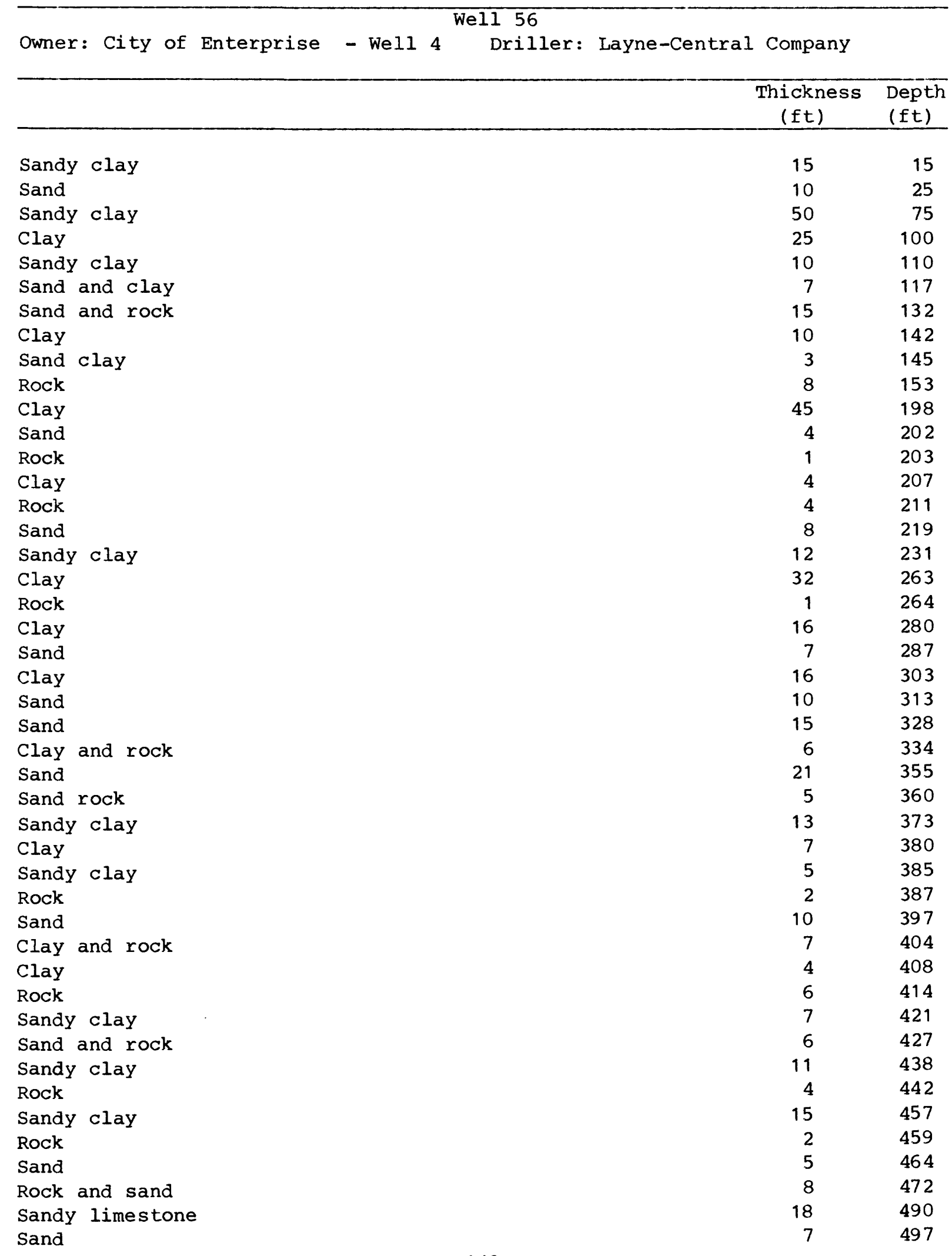


Table 3.--Driller's logs of wells in the Fort Rucker area--Continued

\begin{tabular}{|c|c|c|}
\hline & $\begin{array}{l}\text { Thickness } \\
\text { (ft) }\end{array}$ & $\begin{array}{l}\text { Depth } \\
(\mathrm{ft})\end{array}$ \\
\hline Sand & 7 & 504 \\
\hline Rock & 2 & 506 \\
\hline Sand and limestone & 13 & 519 \\
\hline Limes tone & 23 & 542 \\
\hline Limestone & 46 & 588 \\
\hline Limes tone & 78 & 666 \\
\hline Sand & 14 & 680 \\
\hline Sand & 3 & 683 \\
\hline Limestone and sand & 16 & 699 \\
\hline Sand & 6 & 705 \\
\hline Limestone & 17 & 722 \\
\hline Sand & 4 & 726 \\
\hline Limes tone & 3 & 729 \\
\hline Sand & 3 & 732 \\
\hline Limestone & 3 & 735 \\
\hline Sand & 9 & 744 \\
\hline Limestone & 1 & 745 \\
\hline Sand & 7 & 752 \\
\hline Limestone and sand & 20 & 772 \\
\hline
\end{tabular}


Table 3.--Driller's logs of wells in the Fort Rucker area--Continued

\begin{tabular}{|c|c|c|}
\hline \multicolumn{3}{|c|}{ Well 57} \\
\hline Owner: City of Enterprise - Well 7 & Layne-Central Company & \\
\hline & $\begin{array}{l}\text { Thickness } \\
(f t)\end{array}$ & $\begin{array}{l}\text { Depth } \\
\text { (ft) }\end{array}$ \\
\hline Top soil & 1 & 1 \\
\hline Red clay & 8 & 9 \\
\hline Sandy red clay & 96 & 105 \\
\hline Tough clay & 2 & 107 \\
\hline Sandy clay, gray & 11 & 118 \\
\hline Soft sand & 10 & 128 \\
\hline Hard clay, sand and lime & 11 & 139 \\
\hline Sand, gray, salt and pepper & 5 & 144 \\
\hline Lime rock & 2 & 146 \\
\hline Sand & 2 & 148 \\
\hline Sandy lime & 13 & 161 \\
\hline Clay & 35 & 196 \\
\hline Sand, black & 4 & 200 \\
\hline Rock & 1 & 201 \\
\hline Sandy clay & 3 & 204 \\
\hline Lime & 4 & 208 \\
\hline Clay & 3 & 211 \\
\hline Rock & 1 & 212 \\
\hline Clay and lime, sandy & 17 & 229 \\
\hline Hard clay & 37 & 266 \\
\hline Hard rock & 2 & 268 \\
\hline Clay & 32 & 300 \\
\hline Sandy clay & 12 & 312 \\
\hline Lime rock & 1 & 313 \\
\hline Hard clay, sandy & 10 & 323 \\
\hline Lime & 2 & 325 \\
\hline Hard rock, green sand with lime and clay & 23 & 348 \\
\hline Hard rock sand, green & 17 & 365 \\
\hline Hard rock & 1 & 366 \\
\hline Lime and clay & 7 & 373 \\
\hline Hard pack sand with lime and little clay & 14 & 387 \\
\hline Lime rock & 2 & 389 \\
\hline Sand, clay and rock breaks & 4 & 393 \\
\hline Clay, sand and lime & 20 & 413 \\
\hline Hard clay & 2 & 415 \\
\hline Lime & 1 & 416 \\
\hline Sand with lime and clay & 9 & 425 \\
\hline Clay & 3 & 428 \\
\hline Lime and clay & 6 & 434 \\
\hline Lime rock & 2 & 436 \\
\hline Lime and clay & 5 & 441 \\
\hline Hard lime & 1 & 442 \\
\hline Lime and clay & 11 & 453 \\
\hline Rock & 1 & 454 \\
\hline Clay with lime & 10 & 464 \\
\hline
\end{tabular}


Table 3.--Driller's logs of wells in the Fort Rucker area--Continued

Well 57

\begin{tabular}{|c|c|c|}
\hline & $\begin{array}{c}\text { Thickness } \\
(\mathrm{ft})\end{array}$ & $\begin{array}{l}\text { Depth } \\
(f t)\end{array}$ \\
\hline Hard rock & 1 & 465 \\
\hline Clay and lime & 9 & 474 \\
\hline Lime & 2 & 476 \\
\hline Sandy lime, with clay & 13 & 489 \\
\hline Hard rock & 1 & 490 \\
\hline Sandy lime & 4 & 494 \\
\hline Hard rock & 1 & 495 \\
\hline Sandy lime & 11 & 506 \\
\hline Sandy lime & 23 & 529 \\
\hline Sandy lime & 6 & 535 \\
\hline Lime and clay & 17 & 552 \\
\hline Lime and clay & 14 & 566 \\
\hline White lime, little white clay & 9 & 575 \\
\hline White lime, little white clay & 22 & 597 \\
\hline White lime, little white clay & 22 & 619 \\
\hline White lime, little white clay, harder & 23 & 642 \\
\hline White lime with white clay, hard & 9 & 651 \\
\hline Hard lime & 11 & 662 \\
\hline White lime with clay & 3 & 665 \\
\hline White lime with clay & 6 & 671 \\
\hline Hard lime & 1 & 672 \\
\hline White lime, hard streaks & 11 & 683 \\
\hline Sand & 4 & 687 \\
\hline Sand & 3 & 690 \\
\hline Hard lime, soft streaks, little clay & 18 & 708 \\
\hline Hard lime, soft breaks, sandy and clay & 18 & 726 \\
\hline Sand & 4 & 730 \\
\hline Sand & 5 & 735 \\
\hline Lime and sand, little clay & 11 & 746 \\
\hline Hard lime & 1 & 747 \\
\hline Sand and lime breaks & 6 & 753 \\
\hline Hard lime & 5 & 758 \\
\hline Sand & 3 & 761 \\
\hline Hard lime with clay & 15 & 776 \\
\hline Hard lime with clay & 19 & 795 \\
\hline Lime and clay breaks & 17 & 812 \\
\hline Lime with clay & 9 & 821 \\
\hline Lime and clay, harder & 23 & 844 \\
\hline Lime and clay, hard & 23 & 867 \\
\hline
\end{tabular}


Table 3.--Driller's logs of wells in the Fort Rucker area--Continued

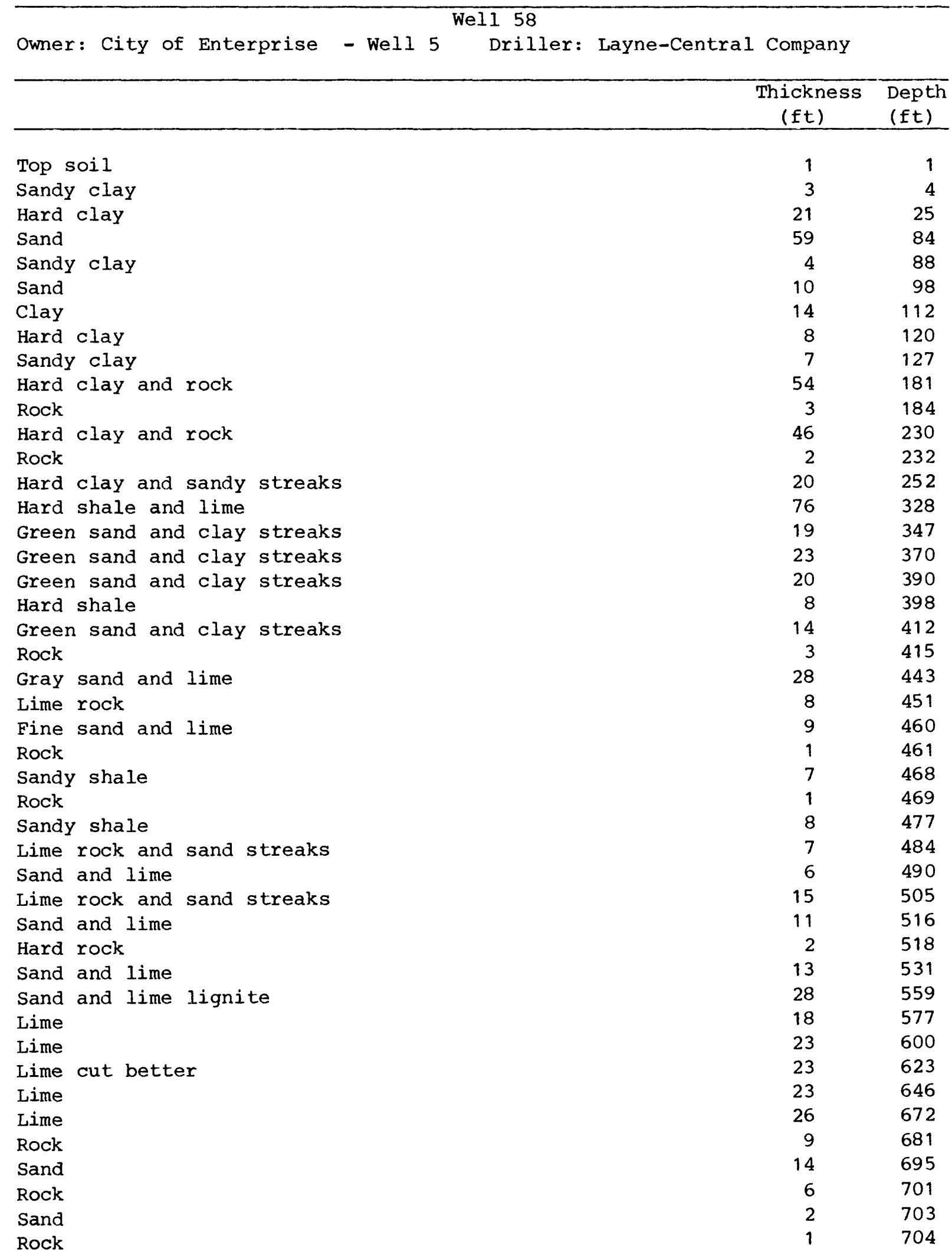


Table 3.--Driller's logs of wells in the Fort Rucker area--Continued

We11 58

\begin{tabular}{lrc}
\hline & $\begin{array}{r}\text { Thickness } \\
\text { (ft) }\end{array}$ & $\begin{array}{c}\text { Depth } \\
\text { (ft) }\end{array}$ \\
\hline Sand & & \\
Rock & 8 & 712 \\
Sand & 1 & 713 \\
Rock & 1 & 714 \\
Sand & 17 & 731 \\
Rock & 9 & 740 \\
Sand and rock & 3 & 743 \\
Sand & 7 & 750 \\
Sand & 11 & 761 \\
Rock & 4 & 765 \\
Sand and rock & 1 & 766 \\
Hard lime & 11 & 777 \\
\end{tabular}


Table 3.--Driller's logs of wells in the Fort Rucker area--Continued

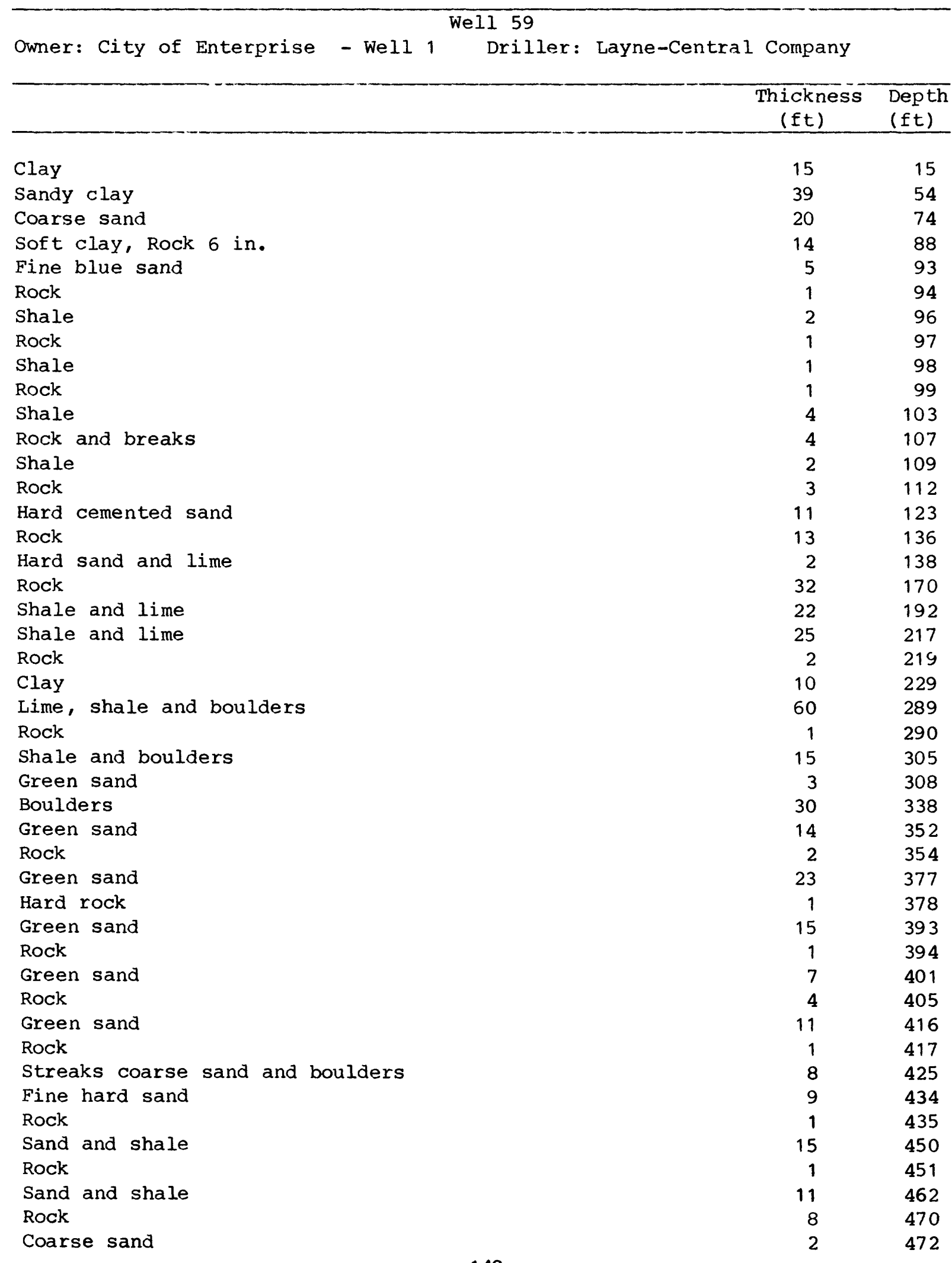


Table 3.--Driller's logs of wells in the Fort Rucker area--Continued

Wel1 59

\begin{tabular}{lrr}
\hline & $\begin{array}{r}\text { Thickness } \\
\text { (ft) }\end{array}$ & $\begin{array}{c}\text { Depth } \\
\text { (ft) }\end{array}$ \\
\hline Rock & 1 & 473 \\
Sand and lime & 18 & 491 \\
Sand and lime & 18 & 509 \\
Hard rock & 2 & 511 \\
Pack sand & 23 & 534 \\
Pack sand, fine & 12 & 546 \\
Lime, soft & 81 & 627 \\
Soft lime & 44 & 671 \\
Hard lime & 9 & 680 \\
Hard fine sand & 26 & 706 \\
Hard fine sand & 7 & 713 \\
Shale and lime & 21 & 734 \\
Fine pack sand & 6 & 740 \\
Rock & 1 & 741 \\
Sand and rock breaks & 29 & 770 \\
Lime rock & 12 & 782
\end{tabular}


Table 3.--Driller's logs of wells in the Fort Rucker area--Continued

\begin{tabular}{|c|c|c|c|}
\hline & Well 60 & & \\
\hline Owner: City of Enterprise & - Well 3 Driller: & Layne-Central Company & \\
\hline & & $\begin{array}{c}\text { Thickness } \\
(f t)\end{array}$ & $\begin{array}{l}\text { Depth } \\
\text { (ft) }\end{array}$ \\
\hline Clay & & 12 & 12 \\
\hline Sand and clay streaks & & 28 & 40 \\
\hline Sand and gravel & & 6 & 46 \\
\hline Clay & & 4 & 50 \\
\hline Sand & & 27 & 77 \\
\hline Clay & & 9 & 86 \\
\hline Rock & & 4 & 90 \\
\hline clay & & 2 & 92 \\
\hline Clay & & 5 & 97 \\
\hline Rock & & 2 & 99 \\
\hline Hard clay & & 4 & 103 \\
\hline Sand & & 4 & 107 \\
\hline Rock & & 2 & 109 \\
\hline Sandy clay & & 7 & 116 \\
\hline Clay & & 5 & 121 \\
\hline Rock & & 1 & 122 \\
\hline Clay & & 11 & 133 \\
\hline Rock & & 1 & 134 \\
\hline Shale & & 6 & 140 \\
\hline Lime rock & & 20 & 160 \\
\hline Sand & & 4 & 164 \\
\hline Rock & & 1 & 165 \\
\hline Shale & & 3 & 168 \\
\hline Rock & & 1 & 169 \\
\hline Shale & & 45 & 214 \\
\hline Rock & & 1 & 215 \\
\hline Shale and lime & & 37 & 252 \\
\hline Rock & & 2 & 254 \\
\hline Shale & & 54 & 308 \\
\hline Sand & & 7 & 315 \\
\hline Shale & & 19 & 334 \\
\hline Sand & & 12 & 346 \\
\hline Rock & & 1 & 347 \\
\hline Sand & & 4 & 351 \\
\hline Rock & & 1 & 352 \\
\hline Sand & & 22 & 374 \\
\hline Rock & & 2 & 376 \\
\hline Sand & & 6 & 382 \\
\hline Shale & & 3 & 385 \\
\hline Sand & & 6 & 391 \\
\hline Rock & & - & - \\
\hline Sand & & 7 & 398 \\
\hline Rock & & 3 & 401 \\
\hline Shale and rock & & 2 & 403 \\
\hline Shale and rock & & 10 & 413 \\
\hline
\end{tabular}


Table 3.--Driller's logs of wells in the Fort Rucker area--Continued

We 1160

\begin{tabular}{|c|c|c|c|}
\hline & & $\begin{array}{l}\text { Thickness } \\
(f t)\end{array}$ & $\begin{array}{l}\text { Depth } \\
(f t)\end{array}$ \\
\hline Rock & & 2 & 415 \\
\hline Sand and rock & & 5 & 420 \\
\hline Rock & & 1 & 421 \\
\hline Sand & & 2 & 423 \\
\hline Rock & & 1 & 424 \\
\hline Sand & & 9 & 433 \\
\hline Rock & & 1 & 434 \\
\hline Shale & & 6 & 440 \\
\hline Rock & & 1 & 441 \\
\hline Sand & & 7 & 448 \\
\hline Rock & & 1 & 449 \\
\hline Shale & & 4 & 453 \\
\hline Shale and rock & & 5 & 458 \\
\hline Shale & & 3 & 461 \\
\hline Rock & & 2 & 463 \\
\hline Sand & & 2 & 465 \\
\hline Rock & & 1 & 466 \\
\hline Sand and lime & & 3 & 469 \\
\hline Rock (lime) & & 13 & 482 \\
\hline Sand and lime & & 6 & 488 \\
\hline Rock & & 2 & 490 \\
\hline Sand and rock & & 9 & 499 \\
\hline Rock & & 1 & 500 \\
\hline Shale and lime & & 4 & 504 \\
\hline Rock & & 2 & 506 \\
\hline Sand, lime and lignite & & 40 & 546 \\
\hline Lime & & 123 & 669 \\
\hline Rock & & 5 & 674 \\
\hline Sand and lime & & 16 & 690 \\
\hline Rock & & 3 & 693 \\
\hline Sand and lime & & 12 & 705 \\
\hline Lime & & 18 & 723 \\
\hline Rock & & 2 & 725 \\
\hline Lime and rock & & 3 & 728 \\
\hline Sand and lime & & 9 & 737 \\
\hline Rock & & 1 & 738 \\
\hline Lime and rock & & 3 & 741 \\
\hline Sand & & 6 & 747 \\
\hline Rock & & 2 & 749 \\
\hline Sand & & 2 & 751 \\
\hline Rock & & 1 & 752 \\
\hline Sand & & 2 & 754 \\
\hline Rock & 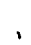 & 1 & 755 \\
\hline Sand & & 4 & 759 \\
\hline Rock & & 1 & 760 \\
\hline Sand & & 4 & 764 \\
\hline Rock & & - & - \\
\hline Sand & & 2 & 766 \\
\hline Lime hard & & 16 & 782 \\
\hline
\end{tabular}


Table 3.--Driller's logs of wells in the Fort Rucker area--Continued

\begin{tabular}{|c|c|c|c|}
\hline \multicolumn{4}{|c|}{ Well 62} \\
\hline Owner: City of Enterprise & - Well 8 & Layne-Central Company & \\
\hline & & $\begin{array}{l}\text { Thickness } \\
\text { (ft) }\end{array}$ & $\begin{array}{l}\text { Depth } \\
\text { (ft) }\end{array}$ \\
\hline Red clay & & 10 & 10 \\
\hline Multi colored clay & & 14 & 24 \\
\hline Sand with clay & & 102 & 126 \\
\hline Rock & & 1 & 127 \\
\hline Gray sandy clay & & 19 & 146 \\
\hline Sand lime shells-clay & & 25 & 171 \\
\hline Hard clay & & 8 & 179 \\
\hline Sandy clay & & 6 & 185 \\
\hline Rock & & 7 & 192 \\
\hline Black clay & & 33 & 225 \\
\hline Sand & & 11 & 236 \\
\hline Sand rock-clay streaks & & 10 & 246 \\
\hline Clay & & 3 & 249 \\
\hline Rock & & 8 & 257 \\
\hline Fine sand with clay & & 35 & 292 \\
\hline Clay and shale & & 23 & 315 \\
\hline Sand with clay & & 8 & 323 \\
\hline Rock & & 1 & 324 \\
\hline Hard clay-sandy & & 57 & 381 \\
\hline Hard sand some clay & & 22 & 403 \\
\hline Rock & & 2 & 405 \\
\hline Hard sand & & 5 & 410 \\
\hline Rock & & 1 & 411 \\
\hline Hard packed sand & & 18 & 429 \\
\hline Soft rock & & 2 & 431 \\
\hline Hard sand & & 12 & 443 \\
\hline Lime rock & & 8 & 451 \\
\hline Hard packed sand & & 13 & 464 \\
\hline Rock & & 1 & 465 \\
\hline Hard packed sand & & 5 & 470 \\
\hline Lime rock & & 3 & 473 \\
\hline Hard packed sand & & 8 & 481 \\
\hline Hard clay & & 2 & 483 \\
\hline Sand with clay & & 5 & 488 \\
\hline Rock & & 1 & 489 \\
\hline Sand with clay & & 8 & 497 \\
\hline Rock & & 1 & 498 \\
\hline Sand & & 1 & 499 \\
\hline Sand with clay & & 4 & 503 \\
\hline Rock & & 1 & 504 \\
\hline Sandy clay & & 3 & 507 \\
\hline Lime rock & & 3 & 510 \\
\hline Sand & & 2 & 512 \\
\hline Lime rock & & 3 & 515 \\
\hline Sand & & 3 & 518 \\
\hline
\end{tabular}


Table 3.--Driller's logs of wells in the Fort Rucker area--Continued

Well 62

\begin{tabular}{|c|c|c|}
\hline & $\begin{array}{c}\text { Thickness } \\
\text { (ft) }\end{array}$ & $\begin{array}{l}\text { Depth } \\
(\mathrm{ft})\end{array}$ \\
\hline Lime rock & 5 & 523 \\
\hline Sand with clay & 2 & 525 \\
\hline Rock & 1 & 526 \\
\hline Sandy lime and clay & 5 & 531 \\
\hline Hard lime-shells & 9 & 540 \\
\hline Sand & 6 & 546 \\
\hline Lime, clay, shells & 8 & 554 \\
\hline Hard lime & 1 & 555 \\
\hline Sand & 5 & 560 \\
\hline Sandy clay & 4 & 564 \\
\hline Sand & 2 & 566 \\
\hline Sand lime shells clay black muck & 23 & 589 \\
\hline Sand, shale black muck & 19 & 608 \\
\hline Hard clay & 12 & 620 \\
\hline Light gray lime & 14 & 634 \\
\hline Light gray lime & 22 & 656 \\
\hline Light gray lime & 23 & 679 \\
\hline Light gray lime & 12 & 691 \\
\hline Soft gray lime with clay & 10 & 701 \\
\hline Soft gray lime with clay & 21 & 722 \\
\hline Hard lime & 2 & 724 \\
\hline Hard lime with clay & 14 & 738 \\
\hline Hard packed sand & 8 & 746 \\
\hline Hard packed sand & 5 & 751 \\
\hline Hard lime & 4 & 755 \\
\hline Soft lime with clay & 4 & 759 \\
\hline Hard lime, sandy & 10 & 769 \\
\hline Clay with lime and sand & 23 & 792 \\
\hline Clay with lime and sand & 4 & 796 \\
\hline Hard lime, sandy clay & 16 & 812 \\
\hline Hard lime, clay & 20 & 832 \\
\hline Hard lime with clay & 20 & 852 \\
\hline Hard lime with clay & 8 & 860 \\
\hline
\end{tabular}


Table 3.--Driller's logs of wells in the Fort Rucker area--Continued

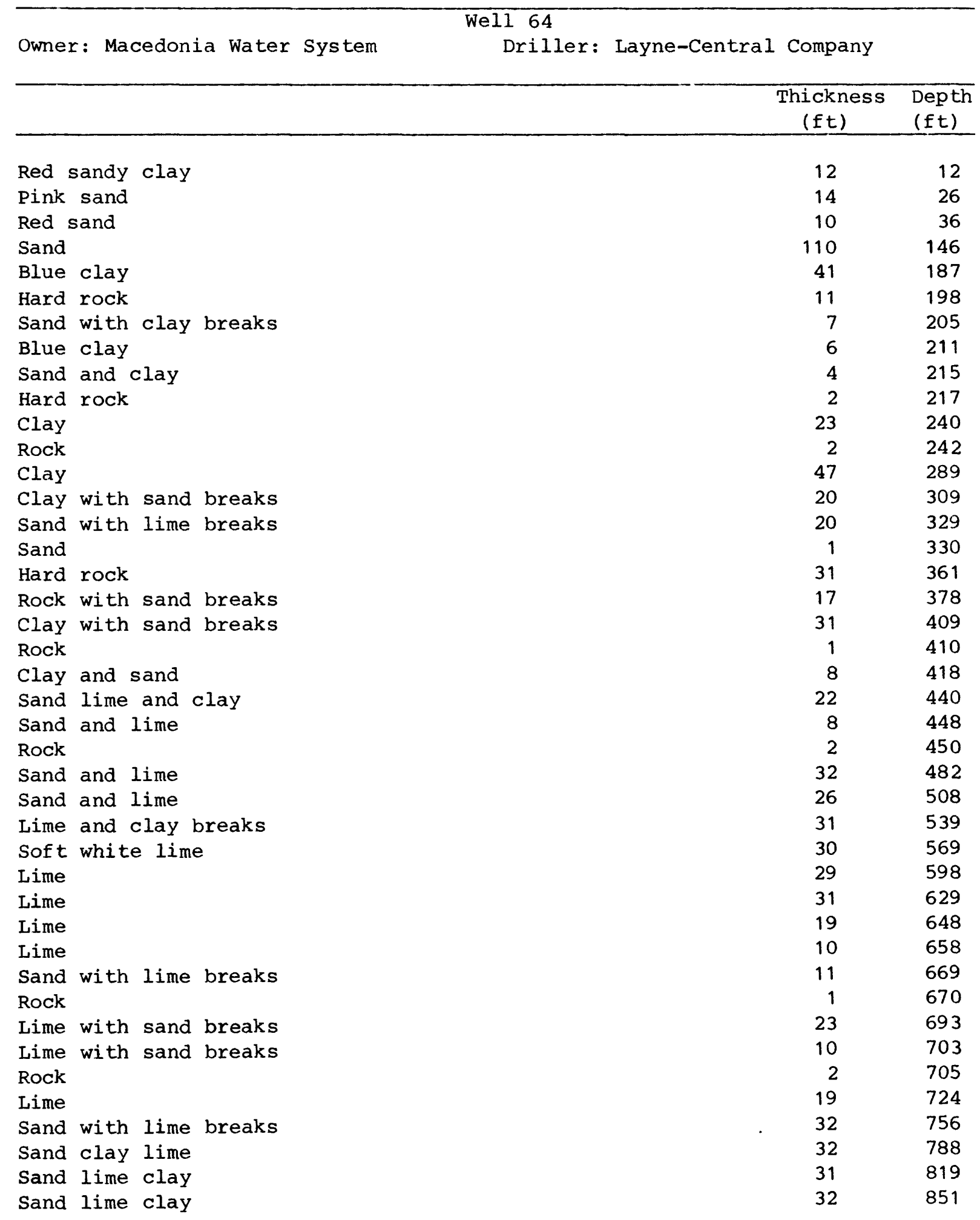


Table 3.--Driller's logs of wells in the Fort Rucker area--Continued

\begin{tabular}{|c|c|c|c|c|}
\hline Owner: & $\begin{array}{l}\text { U.S. Army - Fort Rucker } \\
\text { Well } 1\end{array}$ & $\begin{array}{l}\text { Well } 65 \\
\text { Driller: }\end{array}$ & Layne-Central Company & \\
\hline & & & $\begin{array}{l}\text { Thickness } \\
\text { (ft) }\end{array}$ & $\begin{array}{l}\text { Depth } \\
(\mathrm{ft})\end{array}$ \\
\hline Sandy & clay & & 11 & 11 \\
\hline Shale & & & 34 & 45 \\
\hline Rock & & & 8 & 53 \\
\hline Shale & & & 9 & 62 \\
\hline Sandy & shale & & 12 & 74 \\
\hline Shale & & & 74 & 148 \\
\hline Sand & & & 27 & 175 \\
\hline Rock & & & 5 & 180 \\
\hline Sand & & & 21 & 201 \\
\hline Rock & & & 1 & 202 \\
\hline Sand & & & 17 & 219 \\
\hline Rock & & & 1 & 220 \\
\hline Sand & & & 7 & 227 \\
\hline Hard 1 & lime rock & & 8 & 235 \\
\hline Sand & & & 9 & 244 \\
\hline Fine $\mathbf{s}$ & sand and lime & & 21 & 265 \\
\hline Sandy & shale & & 39 & 304 \\
\hline Rock & & & 2 & 306 \\
\hline Fine $s$ & sand & & 3 & 309 \\
\hline Rock & & & 6 & 315 \\
\hline Sand & & & 10 & 325 \\
\hline Rock & & & 1 & 326 \\
\hline Sand & & & 14 & 340 \\
\hline Lime & & & 82 & 422 \\
\hline Lime a & and hard rock & & 63 & 485 \\
\hline Hard $r$ & cock & & 14 & 498 \\
\hline Sand & & & 20 & 518 \\
\hline Hard $r$ & cock & & 3 & 521 \\
\hline Sand & & & 10 & 531 \\
\hline Rock & & & 1 & 532 \\
\hline Sand & & & 6 & 538 \\
\hline Sand a & and lime & & 39 & 577 \\
\hline Hard $r$ & cock & & 17 & 594 \\
\hline Sand & & & 11 & 605 \\
\hline Rock a & and sand breaks & & 15 & 620 \\
\hline Hard $r$ & cock & & 4 & 624 \\
\hline
\end{tabular}


Table 3.--Driller's logs of wells in the Fort Rucker area--Continued

\begin{tabular}{|c|c|c|c|}
\hline $\begin{aligned} \text { Owner: U.S. Army - Fort Rucker } \\
\text { Well } 2\end{aligned}$ & $\begin{array}{l}\text { Well } 66 \\
\text { Driller: }\end{array}$ & Layne-Central Company & \\
\hline & & $\begin{array}{l}\text { Thickness } \\
\text { (ft) }\end{array}$ & $\begin{array}{l}\text { Depth } \\
\text { (ft) }\end{array}$ \\
\hline Clay & & 20 & 20 \\
\hline Sandy shale & & 7 & 27 \\
\hline Soft rock & & 8 & 35 \\
\hline Shale & & 25 & 60 \\
\hline Sandy shale & & 10 & 70 \\
\hline Rock & & 11 & 81 \\
\hline Shale & & 6 & 87 \\
\hline Sand and shale & & 34 & 121 \\
\hline Rock & & 2 & 123 \\
\hline Shale & & 30 & 153 \\
\hline Rock & & 1 & 154 \\
\hline Shale & & 12 & 166 \\
\hline Clay & & 2 & 168 \\
\hline Sand, rock & & 13 & 181 \\
\hline Sand (draggy) & & 37 & 218 \\
\hline Sand (packed, but better) & & 39 & 257 \\
\hline Sand, cut good & & 18 & 275 \\
\hline Rock & & 1 & 276 \\
\hline Sand and shale & & 18 & 294 \\
\hline Rock & & 1 & 295 \\
\hline Sandy shale & & 11 & 306 \\
\hline Sand & & 14 & 320 \\
\hline Sand & & 4 & 324 \\
\hline Rock & & 2 & 326 \\
\hline Sand & & 4 & 330 \\
\hline Sand & & 4 & 334 \\
\hline Rock & & 2 & 336 \\
\hline Sand & & 10 & 346 \\
\hline Soft rock & & 2 & 348 \\
\hline Sand (draggy) & & 18 & 366 \\
\hline Sandy shale and limestone & & 96 & 462 \\
\hline Lime rock & & 35 & 497 \\
\hline Soft limestone & & 4 & 501 \\
\hline Hard lime rock & & 23 & 524 \\
\hline Sand & & 19 & 543 \\
\hline Rock & & 3 & 546 \\
\hline Sand & & 7 & 553 \\
\hline Limestone & & 2 & 555 \\
\hline Sand & & 2 & 557 \\
\hline Sand, streaks of limestone & & 9 & 566 \\
\hline Sand & & 2 & 568 \\
\hline Rock & & 1 & 569 \\
\hline Limestone & & 56 & 625 \\
\hline Clay & & 5 & 630 \\
\hline Sand & & 2 & 632 \\
\hline
\end{tabular}


Table 3.--Driller's logs of wells in the Fort Rucker area--Continued Well 66

Thickness

Depth

(ft)

(ft)

Rock

Sand

Rock

Clay

Rock

Sand

Rock

$\begin{array}{rr}2 & 634 \\ 15 & 649 \\ 1 & 650 \\ 21 & 671 \\ 3 & 674 \\ 5 & 679 \\ 1 & 680\end{array}$


Table 3.--Driller's logs of wells in the Fort Rucker area--Continued

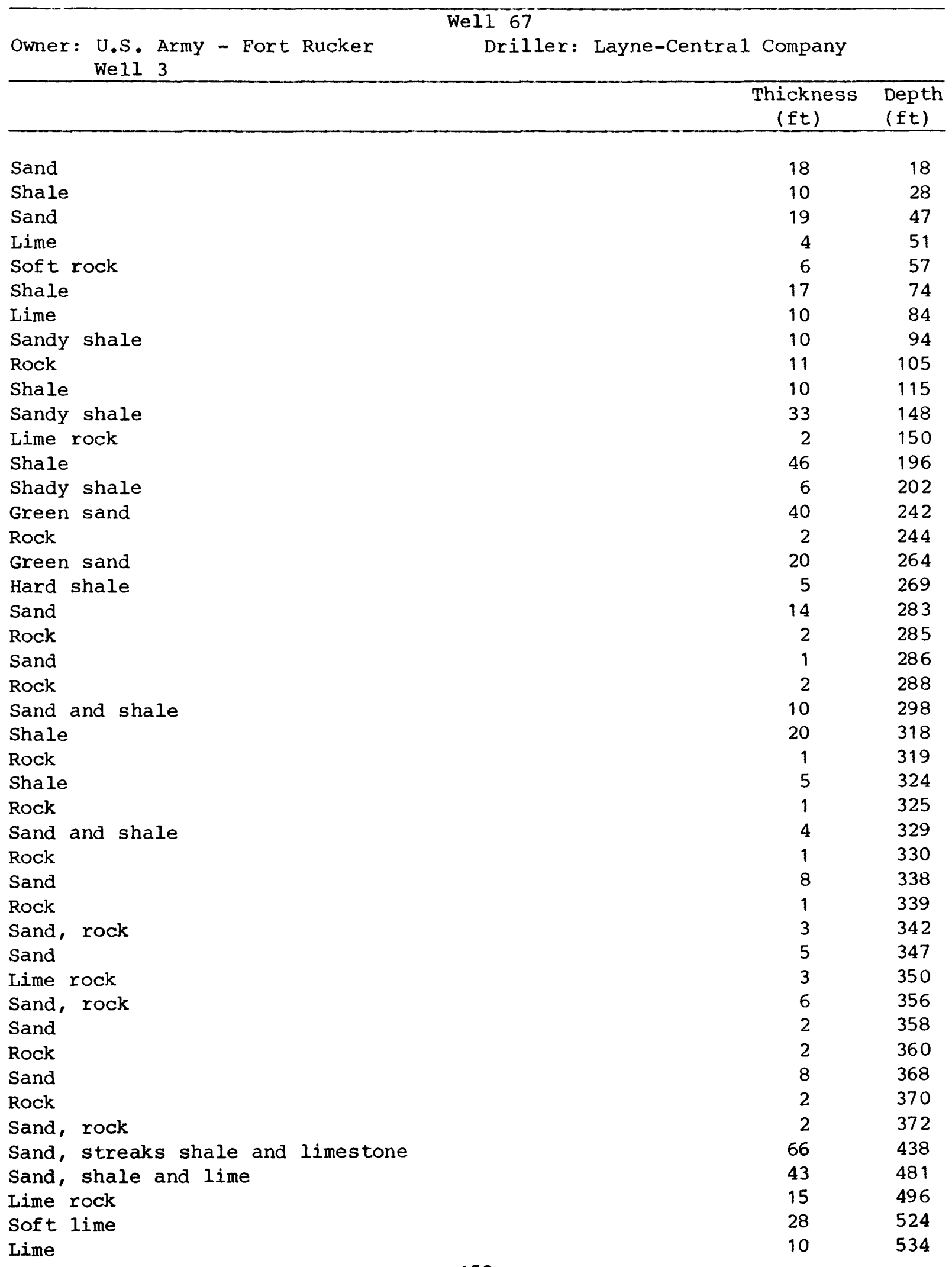


Table 3.--Driller's logs of wells in the Fort Rucker area--Continued

Well 67

Thickness

Depth

(ft)

( $f t)$

Lime rock

15

549

Sand

18

567

Rock

3

570

Sand

5

575

Lime rock

585

Lime rock

590

sand and lime rock

608

sand streaked with lime rock

630

Rock

633

Limes tone

650

Shale

655

Rock

656

Lime, rock

660

Sand, rock

671

sand, rock

674 
Table 3.--Driller's logs of wells in the Fort Rucker area--Continued

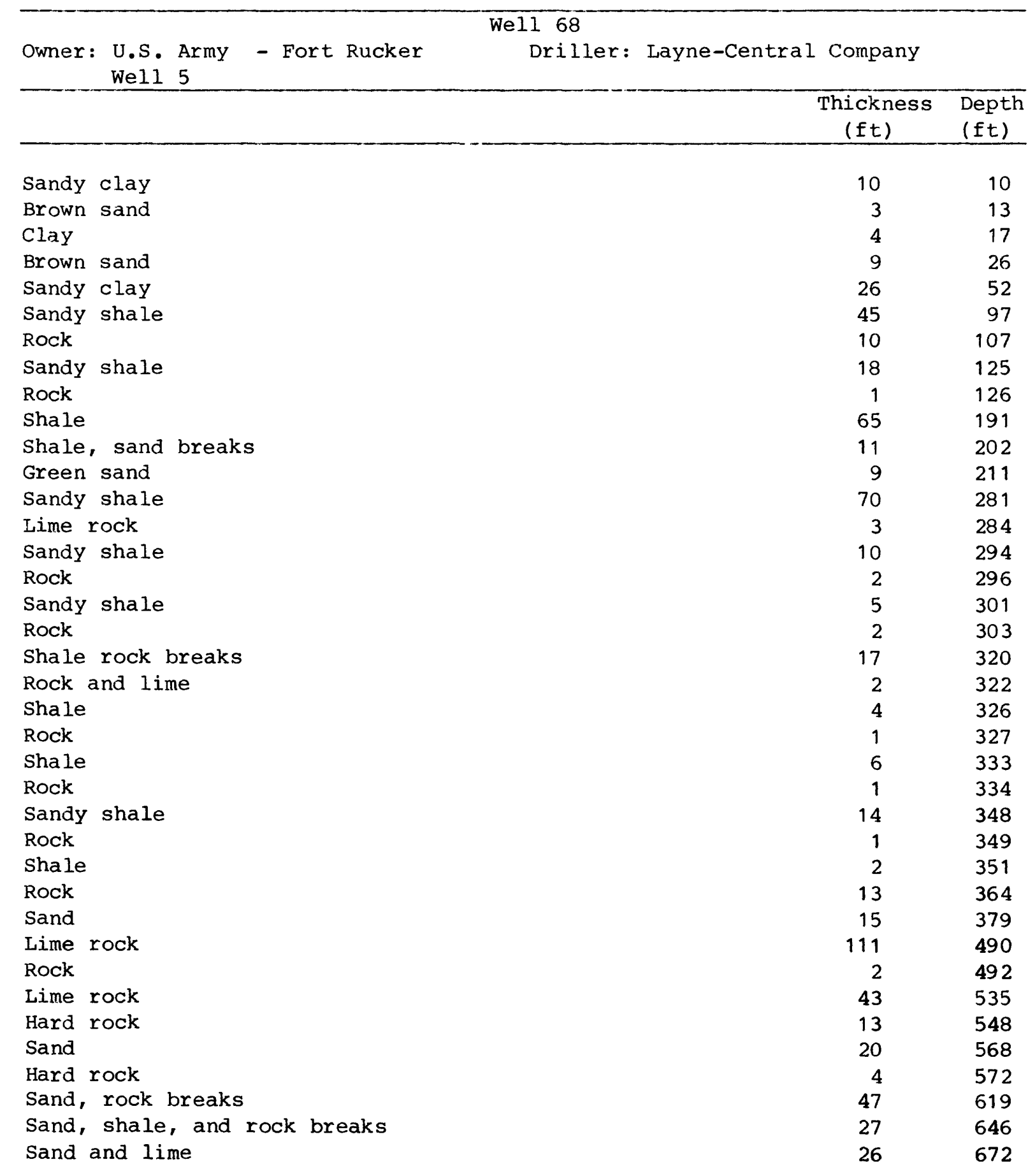


Table 3.--Driller's logs of wells in the Fort Rucker area--Continued

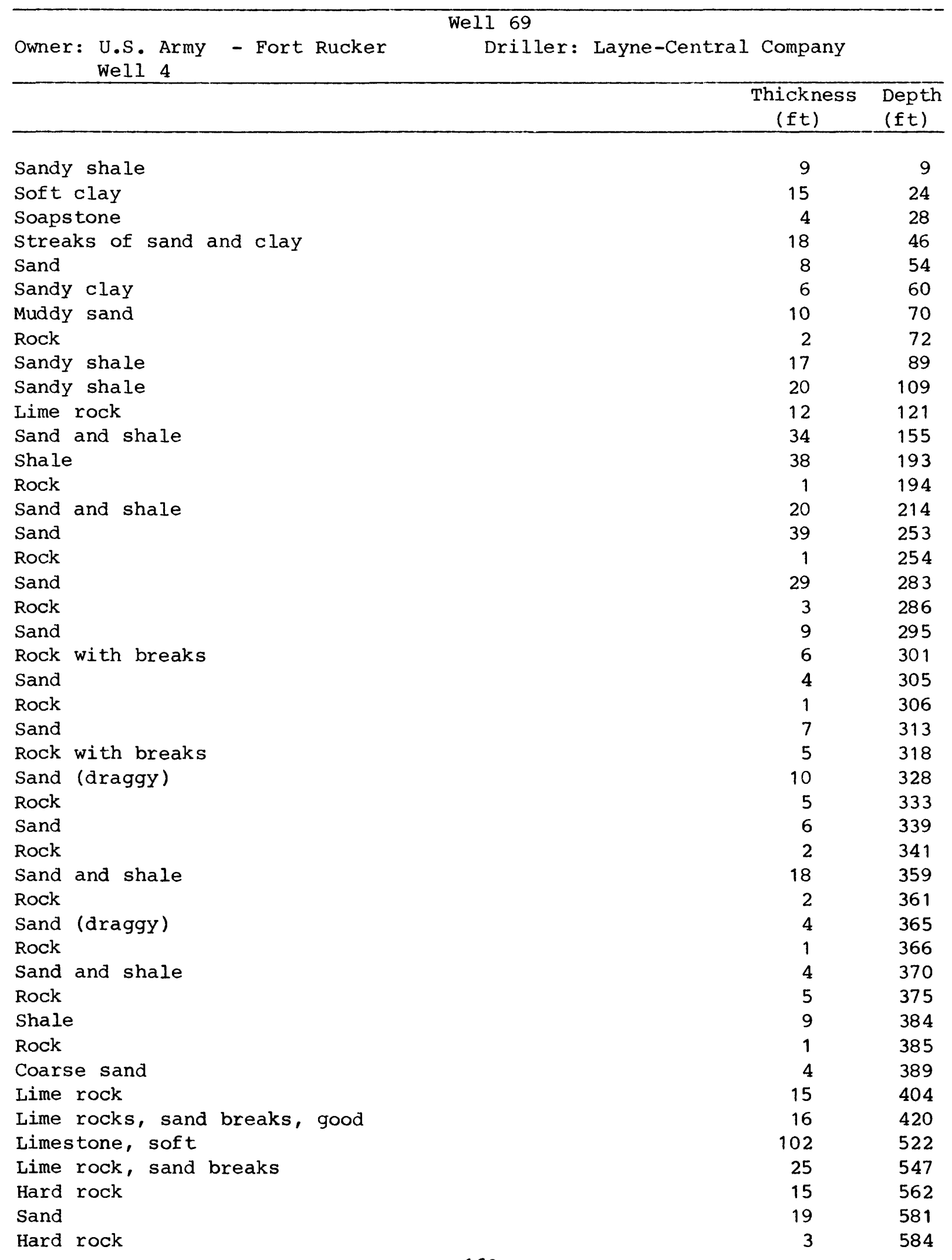


Table 3.--Driller's logs of wells in the Fort Rucker area--Continued

Well 69

\begin{tabular}{|c|c|c|}
\hline & $\begin{array}{l}\text { Thickness } \\
(\mathrm{ft})\end{array}$ & $\begin{array}{l}\text { Depth } \\
(\mathrm{ft})\end{array}$ \\
\hline Soft lime & 13 & 597 \\
\hline Sand & 4 & 601 \\
\hline Rock & 1 & 602 \\
\hline Lime rock, sand breaks & 6 & 608 \\
\hline Lime rock & 5 & 613 \\
\hline Sand & 5 & 618 \\
\hline Lime rock, sand breaks & 37 & 655 \\
\hline Hard rock & 7 & 662 \\
\hline Lime rock & 8 & 670 \\
\hline Sand & 19 & 689 \\
\hline Rock & 1 & 690 \\
\hline Gummy shale & 14 & 704 \\
\hline Lime rock & 1 & 705 \\
\hline Shale & 6 & 711 \\
\hline Rock & 2 & 713 \\
\hline Sand & 3 & 716 \\
\hline Rock and sand breaks & 10 & 726 \\
\hline Sand & 5 & 731 \\
\hline Rock and sand breaks & 27 & 758 \\
\hline Lime rock & 2 & 760 \\
\hline Rock & 2 & 762 \\
\hline Lime rock, streaks of shale & 32 & 794 \\
\hline Sand and rock breaks & 27 & 821 \\
\hline Hard rock & 8 & 829 \\
\hline Sand and rock & 17 & 846 \\
\hline Hard rock & 2 & 848 \\
\hline Rock and breaks & 18 & 866 \\
\hline Shale and lime & 9 & 875 \\
\hline Sand & 2 & 877 \\
\hline Rock & 2 & 879 \\
\hline Shale and sand breaks & 12 & 891 \\
\hline Sandy shale & 21 & 912 \\
\hline Tough shale & 88 & 1000 \\
\hline
\end{tabular}


Table 3.--Driller's logs of wells in the Fort Rucker area--Continued

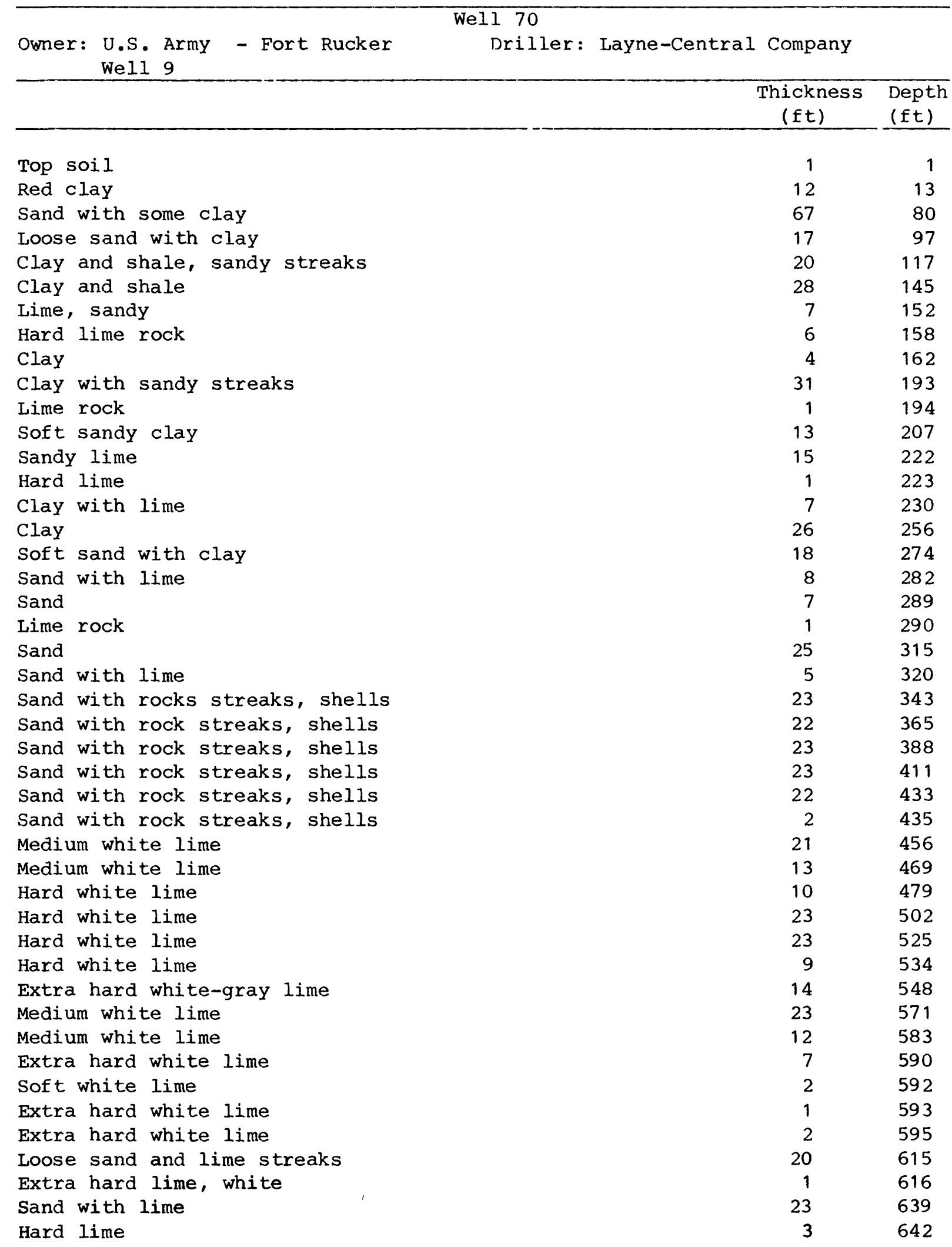


Table 3.--Driller's logs of wells in the Fort Rucker area--Continued

\begin{tabular}{|c|c|c|}
\hline & $\begin{array}{l}\text { Thickness } \\
\text { (ft) }\end{array}$ & $\begin{array}{l}\text { Depth } \\
\text { (ft) }\end{array}$ \\
\hline Sand & 7 & 649 \\
\hline Extra hard lime & 1 & 650 \\
\hline Sand & 3 & 653 \\
\hline Extra hard lime & 1 & 654 \\
\hline Sand and lime streaks & 7 & 661 \\
\hline Extra hard sandy lime & 22 & 683 \\
\hline Extra hard sandy lime & 9 & 692 \\
\hline Soft sandy lime & 5 & 697 \\
\hline Extra hard sandy lime & 9 & 706 \\
\hline Soft sandy lime & 12 & 718 \\
\hline Extra hard lime & 2 & 720 \\
\hline Soft sandy lime & 6 & 726 \\
\hline Extra hard lime & 2 & 728 \\
\hline Clay with hard lime streaks & 23 & 751 \\
\hline Extra hard lime with clay and sand & 22 & 773 \\
\hline Extra hard lime with clay & 9 & 782 \\
\hline sand & 4 & 786 \\
\hline Extra hard lime with clay & 24 & 810 \\
\hline Lime and sand streaks, cut rough & 9 & 819 \\
\hline Extra hard lime with clay & 4 & 823 \\
\hline Lime and sand streaks, cut rough & 18 & 841 \\
\hline Lime and sand streaks, lime smooth & 23 & 864 \\
\hline Lime and sand streaks, lime hard and smooth & 23 & 887 \\
\hline Lime and sand streaks, lime hard and smooth & 22 & 909 \\
\hline Lime and sand streaks, lime hard and smooth & 2 & 911 \\
\hline Clay with hard lime streaks & 21 & 932 \\
\hline Clay, hard on bottom & 23 & 955 \\
\hline Hard clay & 113 & 1068 \\
\hline Hard clay, sandy streaks & 23 & 1091 \\
\hline Hard clay & 68 & 1159 \\
\hline
\end{tabular}


Table 3.--Driller's logs of wells in the Fort Rucker area--Continued

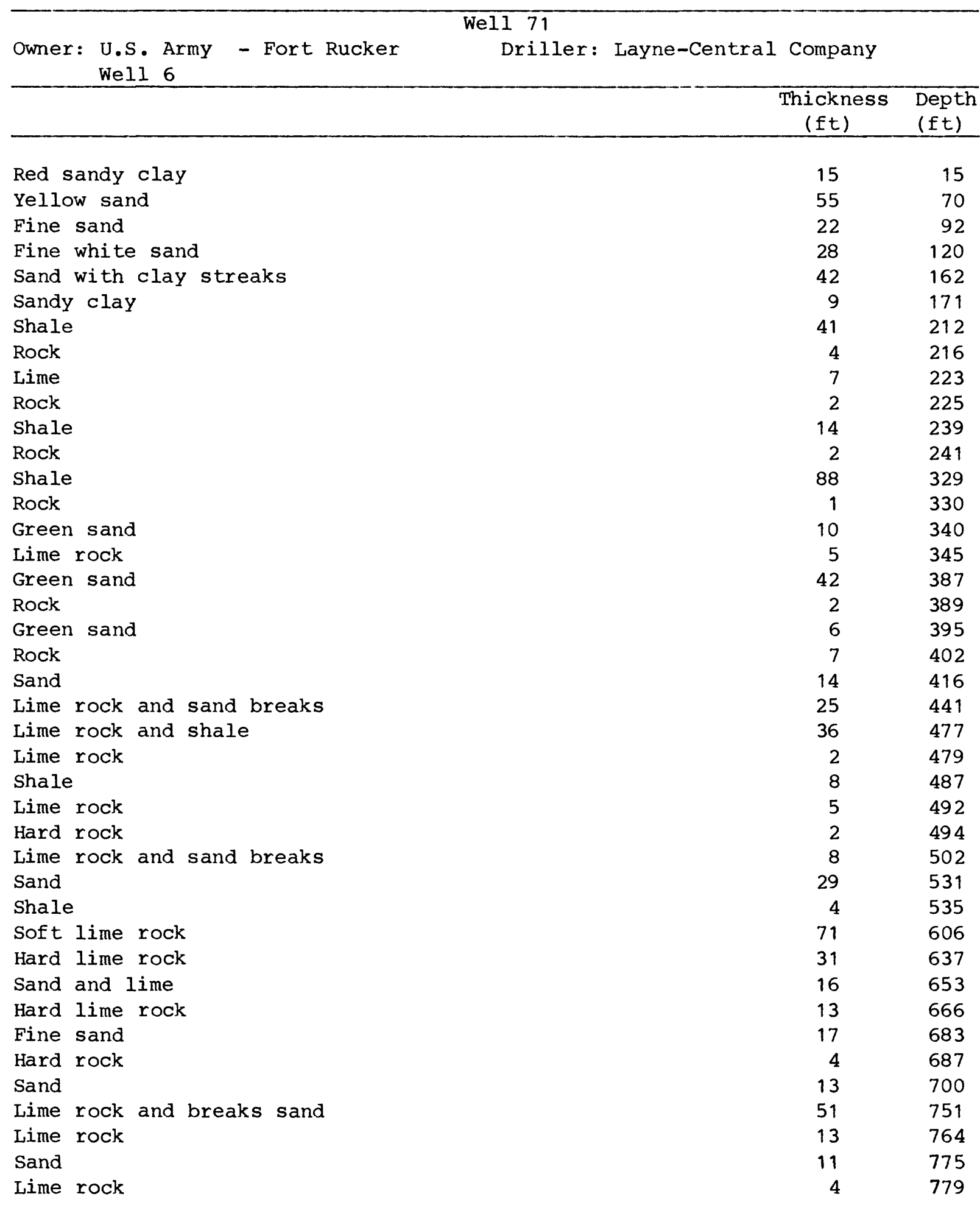


Table 3.--Driller's logs of wells in the Fort Rucker area--Continued

\section{Well 73}

Owner: Town of Level Plains - Well 1 Driller: Tom Smith Artesian Well Co.

\begin{tabular}{|c|c|c|}
\hline & $\begin{array}{l}\text { Thickness } \\
\text { (ft) }\end{array}$ & $\begin{array}{l}\text { Depth } \\
(f t)\end{array}$ \\
\hline Clay & 15 & 15 \\
\hline Yellow sand & 25 & 40 \\
\hline Yellow sand & 5 & 45 \\
\hline Clay & 5 & 50 \\
\hline Yellow sand & 50 & 100 \\
\hline Yellow marl & 10 & 110 \\
\hline Blue marl & 15 & 125 \\
\hline Rock breaks and shell & 5 & 130 \\
\hline Marl & 10 & 140 \\
\hline Shell and sand (blue-gray) & 20 & 160 \\
\hline Marl & 55 & 215 \\
\hline Rock (blue-hard) & 1 & 216 \\
\hline Marl & 22 & 238 \\
\hline Rock & 2 & 240 \\
\hline Sandy marl & 20 & 260 \\
\hline Marl & 17 & 277 \\
\hline Sandy & 3 & 280 \\
\hline Marl & 37 & 317 \\
\hline Sandy marl & 23 & 340 \\
\hline Sand & 10 & 350 \\
\hline Sand & 10 & 360 \\
\hline Sand & 20 & 380 \\
\hline Sandy marl & 35 & 415 \\
\hline Rock & 2 & 417 \\
\hline Marl & 33 & 450 \\
\hline Sand rock breaks & 10 & 460 \\
\hline Sandy marl and shell & 20 & 480 \\
\hline Shell rocks and sand & 5 & 485 \\
\hline Limestone with sand & 15 & 500 \\
\hline Gray rock some sand & 20 & 520 \\
\hline Gray rock and black marl or charcoal sand & 20 & 540 \\
\hline Gray rock and black marl or charcoal sand & 15 & 555 \\
\hline Limestone & 5 & 560 \\
\hline Limes tone & 20 & 580 \\
\hline Limes tone & 20 & 600 \\
\hline Limestone & 40 & 640 \\
\hline Limestone & 40 & 680 \\
\hline
\end{tabular}


Table 3.--Driller's logs of wells in the Fort Rucker area--Continued

Well 74

Owner: Town of Daleville - Well 2 Driller: Layne-Central Company

\begin{tabular}{|c|c|c|}
\hline & $\begin{array}{l}\text { Thickness } \\
\text { (ft) }\end{array}$ & $\begin{array}{l}\text { Depth } \\
(\mathrm{ft})\end{array}$ \\
\hline Clay & 11 & 11 \\
\hline Sand and gravel & 38 & 49 \\
\hline Clay & 9 & 58 \\
\hline Sand and gravel & 12 & 70 \\
\hline Clay & 40 & 110 \\
\hline Clay and rock & 10 & 120 \\
\hline Rock & 8 & 128 \\
\hline Clay and rock & 12 & 140 \\
\hline Sand & 9 & 149 \\
\hline Clay & 43 & 192 \\
\hline Rock & 3 & 195 \\
\hline Clay & 29 & 224 \\
\hline Rock & 2 & 226 \\
\hline Clay & 43 & 269 \\
\hline Rock & 2 & 271 \\
\hline Clay & 30 & 301 \\
\hline Sand & 20 & 321 \\
\hline Sand & 12 & 333 \\
\hline Limerock & 3 & 336 \\
\hline Sand & 8 & 344 \\
\hline Sand and lime & 17 & 361 \\
\hline Sand, clay, lime & 25 & 386 \\
\hline Rock & 3 & 389 \\
\hline Sand & 12 & 401 \\
\hline Rock & 2 & 403 \\
\hline Clay and rock & 15 & 418 \\
\hline Clay and shells & 5 & 423 \\
\hline Rock & 1 & 424 \\
\hline Clay and shells & 2 & 426 \\
\hline Rock & 1 & 427 \\
\hline Clay and lime & 11 & 438 \\
\hline Pack & 2 & 440 \\
\hline Clay shells and lime & 21 & 461 \\
\hline Sand & 4 & 465 \\
\hline Limerock & 5 & 470 \\
\hline Sand & 10 & 480 \\
\hline Limerock & 1 & 481 \\
\hline Sand & 2 & 483 \\
\hline Limerock & 2 & 485 \\
\hline Sand & 4 & 489 \\
\hline Lime and rock & 1 & 490 \\
\hline Sand and lime & 15 & 505 \\
\hline Clay & 36 & 541 \\
\hline Lime & 10 & 551 \\
\hline Lime & 23 & 574 \\
\hline
\end{tabular}


Table 3.--Driller's logs of wells in the Fort Rucker area--Continued Well 74

\begin{tabular}{|c|c|c|}
\hline & $\begin{array}{l}\text { Thickness } \\
\text { (ft) }\end{array}$ & $\begin{array}{l}\text { Depth } \\
\text { (ft) }\end{array}$ \\
\hline Lime & 12 & 586 \\
\hline Lime & 25 & 611 \\
\hline Lime & 32 & 643 \\
\hline Lime & 12 & 655 \\
\hline Sand & 16 & 671 \\
\hline Lime & 5 & 676 \\
\hline Sand & 6 & 682 \\
\hline Lime & 6 & 688 \\
\hline Sand & 5 & 693 \\
\hline Lime & 4 & 697 \\
\hline Sand & 4 & 701 \\
\hline Lime & 10 & 711 \\
\hline
\end{tabular}


Table 3.--Driller's logs of wells in the Fort Rucker area--Continued

\begin{tabular}{|c|c|c|c|}
\hline & Wel1 75 & & \\
\hline Owner: Town of Daleville & Driller: & Layne-Central Company & \\
\hline & & $\begin{array}{l}\text { Thickness } \\
\text { (ft) }\end{array}$ & $\begin{array}{l}\text { Depth } \\
\text { (ft) }\end{array}$ \\
\hline Top soil & & 2 & 2 \\
\hline Red clay & & 14 & 16 \\
\hline Sand & & 4 & 20 \\
\hline Sand and gravel & & 25 & 45 \\
\hline Sand and clay & & 16 & 61 \\
\hline Clay & & 16 & 77 \\
\hline Sand & & 11 & 88 \\
\hline Clay and rock & & 22 & 110 \\
\hline Rock & & 10 & 120 \\
\hline Clay & & 3 & 123 \\
\hline Rock & & 7 & 130 \\
\hline Clay and rock & & 6 & 136 \\
\hline Rock & & 3 & 139 \\
\hline Clay & & 58 & 197 \\
\hline Rock & & 2 & 199 \\
\hline Clay & & 30 & 229 \\
\hline Rock & & 1 & 230 \\
\hline Clay & & 70 & 300 \\
\hline Sand & & 21 & 321 \\
\hline Sand & & 10 & 331 \\
\hline Rock & & 4 & 335 \\
\hline Sand & & 9 & 344 \\
\hline Sand & & 22 & 366 \\
\hline Sand & & 18 & 384 \\
\hline Rock & & 5 & 389 \\
\hline Sand & & 7 & 396 \\
\hline Rock & & 2 & 398 \\
\hline Sand & & 2 & 400 \\
\hline Rock & & 2 & 402 \\
\hline Sandy clay & & 4 & 406 \\
\hline Rock & & 1 & 407 \\
\hline Clay & & 49 & 456 \\
\hline Clay and rock & & 9 & 465 \\
\hline Sand & & 5 & 470 \\
\hline Clay and rock & & 3 & 473 \\
\hline Sand and shells & & 13 & 486 \\
\hline Sand and shells & & 7 & 493 \\
\hline Rock & & 5 & 498 \\
\hline Sand & & 12 & 510 \\
\hline Sandy clay & & 18 & 528 \\
\hline Sandy clay & & 27 & 555 \\
\hline Sandy clay & & 20 & 575 \\
\hline Iimerock & & 25 & 600 \\
\hline Limerock & & 22 & 622 \\
\hline Limerock & & 17 & 639 \\
\hline
\end{tabular}


Table 3.--Driller's logs of wells in the Fort Rucker area--Continued

We11 75

\begin{tabular}{lrc}
\hline & $\begin{array}{c}\text { Thickness } \\
\text { (ft) }\end{array}$ & $\begin{array}{l}\text { Depth } \\
\text { (ft) }\end{array}$ \\
\hline Limerock & 5 & \\
Limerock & 5 & 644 \\
Sand & 3 & 647 \\
Limerock & 18 & 665 \\
Limerock & 2 & 667 \\
Limerock & 3 & 670 \\
Sand & 8 & 678 \\
Sand & 11 & 689 \\
Limerock and sand & 3 & 692 \\
Limerock & 19 & 711 \\
Limerock & 22 & 733 \\
\end{tabular}


Table 3.--Driller's logs of wells in the Fort Rucker area--Continued

\begin{tabular}{|c|c|c|}
\hline $\begin{array}{ll}\text { Owner: U.S. Army - Fort Rucker } \\
\text { Airfield } \\
\end{array}$ & Layne-Central Company & \\
\hline & $\begin{array}{l}\text { Thickness } \\
\text { (ft) }\end{array}$ & $\begin{array}{l}\text { Depth } \\
(\mathrm{ft})\end{array}$ \\
\hline Clay, red and gray & 10 & 10 \\
\hline Fine sand, some rock, gray clay & 27 & 37 \\
\hline Clay, red and gray, fine sand & 30 & 67 \\
\hline Clay, red and gray, fine sand, some rock & 20 & 87 \\
\hline Red and gray clay & 18 & 105 \\
\hline Gray clay, shells & 10 & 115 \\
\hline Gray white limestone & 13 & 128 \\
\hline Sand, gray and white limestone & 19 & 147 \\
\hline Gray clay, shell, some limestone & 12 & 159 \\
\hline Gray clay, some limestone & 93 & 252 \\
\hline Red and gray clay & 40 & 292 \\
\hline Gray sand, some gray clay and limestone & 10 & 302 \\
\hline Mostly sand; some red and gray clay & 44 & 346 \\
\hline Very fine sand & 9 & 355 \\
\hline Fine sand, red clay, some limestone & 10 & 365 \\
\hline Sand, red clay, limestone & 12 & 377 \\
\hline Sand, red clay, limestone & 10 & 387 \\
\hline Limestone, some sand & 10 & 397 \\
\hline Sand, limestone, some red clay & 10 & 407 \\
\hline Mostly gray clay & 10 & 417 \\
\hline Mostly gray clay, some red clay & 10 & 427 \\
\hline Gray clay, shells, specks of red clay & 11 & 438 \\
\hline Gray clay, some red clay, limestone & 9 & 447 \\
\hline Gray clay, some red clay & 10 & 457 \\
\hline Sand and shells, some gray clay & 12 & 469 \\
\hline Gray clay, some shells & 9 & 478 \\
\hline Sand and shells, gray clay & 10 & 488 \\
\hline Sand, gray clay, shells & 11 & 499 \\
\hline Red and gray clay & 10 & 509 \\
\hline Sand, shells, red clay & 10 & 519 \\
\hline Limestone, some red clay & 12 & 531 \\
\hline Red and gray clay & 10 & 541 \\
\hline Limestone, fossils & 10 & 551 \\
\hline Limestone, fossils & 12 & 563 \\
\hline Red clay, gray clay, limestone & 10 & 573 \\
\hline Limestone, some chalky & 10 & 583 \\
\hline Limestone, real chalky & 12 & 595 \\
\hline Fine chalky limestone, some clay & 9 & 604 \\
\hline Fine to medium coarse chalky limestone & 10 & 614 \\
\hline Chalky limestone & 13 & 627 \\
\hline Red and gray clay, some limestone & 10 & 637 \\
\hline Chalky limestone & 10 & 647 \\
\hline Fine sand, chalky limestone & 12 & 659 \\
\hline Fine sand, chalky limestone & 10 & 669 \\
\hline Sand, chalky limestone, some clay & 10 & 679 \\
\hline
\end{tabular}


Table 3.--Driller's logs of wells in the Fort Rucker area--Continued

Well 76

\begin{tabular}{lrr}
\hline & $\begin{array}{c}\text { Thickness } \\
\text { (ft) }\end{array}$ & $\begin{array}{c}\text { Depth } \\
\text { (ft) }\end{array}$ \\
\hline Mostly sand, some limestone & 11 & 690 \\
Very fine silty sand & 10 & 700 \\
White chalky clay and limestone & 10 & 710 \\
White chalky clay, coarse limestone & 11 & 721 \\
Chalky clay, some limestone & 10 & 731 \\
Gray clay, chalky limestone & 10 & 741 \\
Gray clay, chalky limestone, some fine sand & 12 & 753 \\
Sand, chalky limestone & 10 & 763 \\
Sand, chalky limestone & 10 & 773 \\
Sand, chalky limestone & 11 & 784 \\
Fine sand, chalky limestone & 10 & 794 \\
Fine sand, chalky limestone & 10 & 804 \\
Sand, chalky limestone & 10 & 814 \\
Fine to medium coarse sand, chalky limestone & 10 & 824 \\
Fine to medium coarse sand, chalky limestone & 10 & 834 \\
Mostly fine sand, some chalky limestone & 12 & 846 \\
Fine silty sand, some limestone & 9 & 855 \\
Fine silty sand, some limestone & 10 & 865 \\
Fine silty sand, chalky limestone & 12 & 877 \\
Fine sand, some limestone & 10 & 887 \\
Sand, limestone & 10 & 897 \\
Gray clay, limestone & 12 & 909 \\
Gray clay, limestone & 9 & 918 \\
Gray clay, limestone, some sand & 10 & 928 \\
Medium coarse tan sand, some gray clay & 12 & 940 \\
Fine silty sand, some gray clay & 10 & 950 \\
Sand, gray clay, limestone & 10 & 960 \\
Sand, gray clay, limestone & 11 & 971 \\
Fine sand sond, some gray clay & 9 & 980 \\
Fine sand, & 12 & 990 \\
Sand, gray clay, limestone & 1002 \\
Sand, limestone, gray clay & 10 & 1012 \\
Limestone, gray clay, some sand & 12 & 1034 \\
Mostly gray clay, some limestone & & 10 \\
& & 10 \\
\end{tabular}


Table 3.--Driller's logs of wells in the Fort Rucker area--Continued

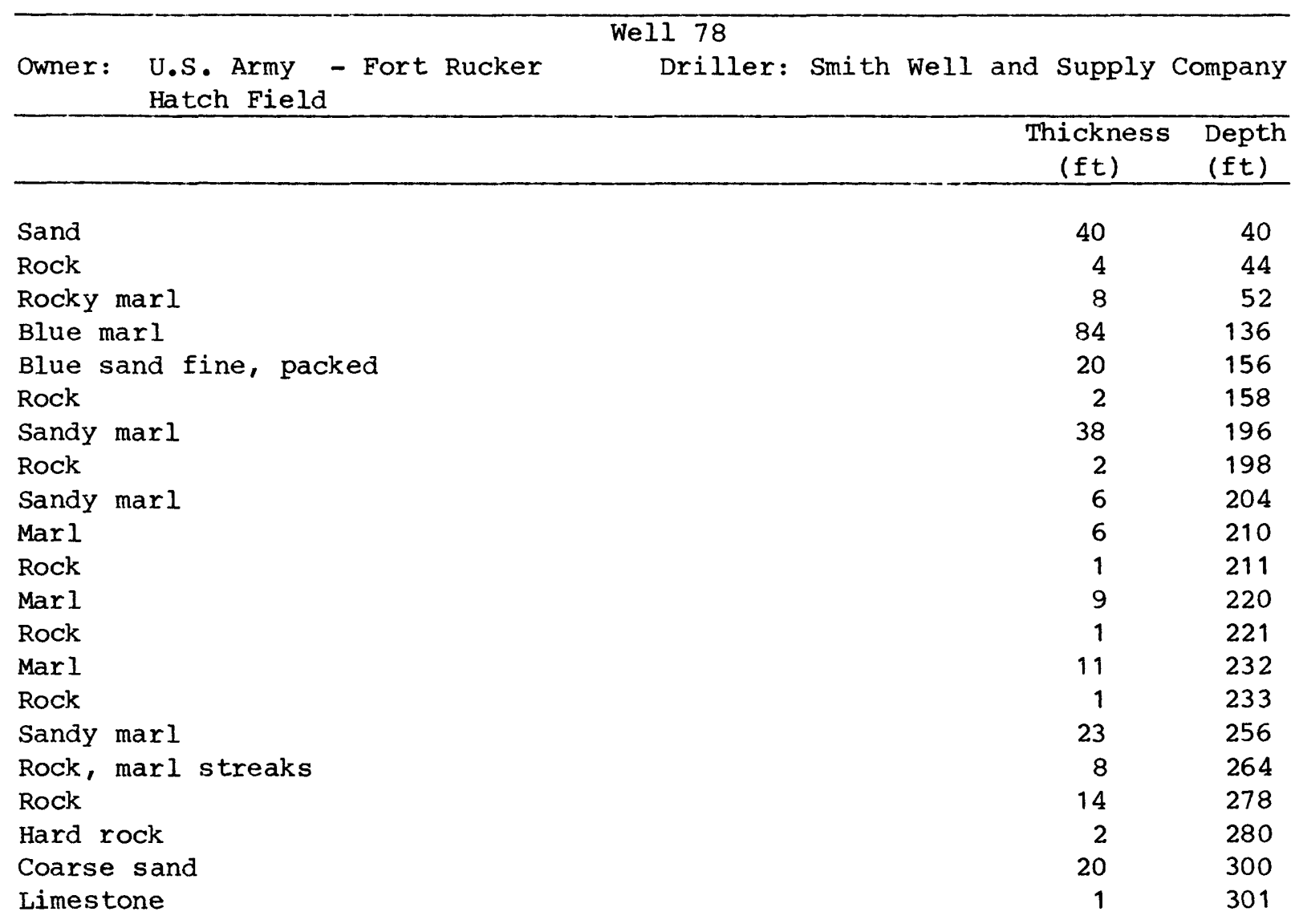


Table 3.--Driller's logs of wells in the Fort Rucker area--Continued

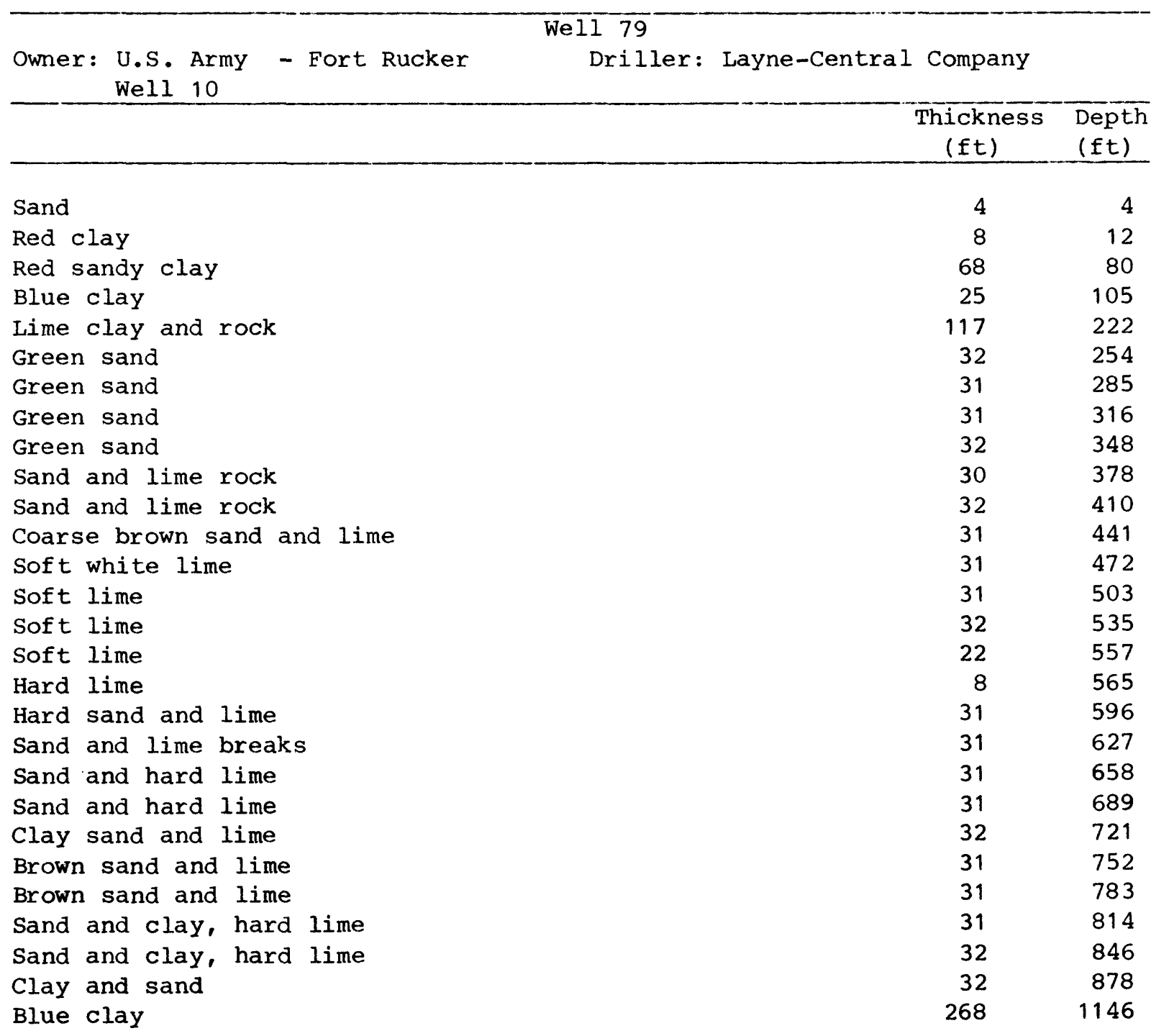


Table 3.--Driller's logs of wells in the Fort Rucker area--Continued

\begin{tabular}{|c|c|c|c|}
\hline \multirow{2}{*}{ Town of Newton } & \multirow{2}{*}{$\begin{array}{l}\text { Well } 80 \\
\text { Driller: }\end{array}$} & Layne-Central Company & \multirow[b]{2}{*}{$\begin{array}{l}\text { Depth } \\
(\mathrm{ft})\end{array}$} \\
\hline & & $\begin{array}{l}\text { Thickness } \\
\text { (ft) }\end{array}$ & \\
\hline Clay, red, sandy & & 12 & 12 \\
\hline Sand, clay balls & & 8 & 20 \\
\hline Sand, white, coarse and gravel & & 52 & 72 \\
\hline Clay & & 1 & 73 \\
\hline Sand, red, fine & & 8 & 81 \\
\hline Limestone & & 12 & 93 \\
\hline Rock & & 4 & 97 \\
\hline Clay, hard & & 19 & 116 \\
\hline Rock & & 2 & 118 \\
\hline Clay & & 14 & 132 \\
\hline Rock & & 2 & 134 \\
\hline Shale, hard & & 36 & 170 \\
\hline Rock & & 3 & 173 \\
\hline Shale, blue, hard & & 29 & 202 \\
\hline Rock & & 1 & 203 \\
\hline Clay & & 12 & 215 \\
\hline Sand, gray, fine & & 13 & 228 \\
\hline Rock & & 2 & 230 \\
\hline Shale & & 55 & 285 \\
\hline Sand, fine, hard streaks & & 4 & 289 \\
\hline Sand, gray, coarse & & 9 & 298 \\
\hline Rock & & 1 & 299 \\
\hline Shale, sand, streaks & & 29 & 328 \\
\hline Shale, hard & & 17 & 345 \\
\hline Limestone, hard & & 11 & 356 \\
\hline Shale & & 5 & 361 \\
\hline Limestone, soft & & 12 & 373 \\
\hline Rock & & 1 & 374 \\
\hline Limestone, soft & & 46 & 420 \\
\hline Rock & & 3 & 423 \\
\hline Limes tone & & 26 & 449 \\
\hline Sand, limestone breaks & & 24 & 473 \\
\hline Limestone, white, soft & & 58 & 531 \\
\hline Limestone, hard & & 68 & 599 \\
\hline Sand, hard & & 12 & 611 \\
\hline Rock, hard & & 2 & 613 \\
\hline Sand, hard & & 1 & 614 \\
\hline Rock, hard & & 7 & 621 \\
\hline Sand, hard & & 13 & 634 \\
\hline Rock, sand breaks & & 12 & 646 \\
\hline Sand, hard & & 13 & 659 \\
\hline Rock & & 1 & 660 \\
\hline Limestone, hard; soft streaks & & 8 & 668 \\
\hline Sand & & 4 & 672 \\
\hline Rock & & 2 & 674 \\
\hline
\end{tabular}


Table 3.--Driller's logs of wells in the Fort Rucker area--Continued Wel1 80

Thickness Depth
(ft)

Sand

Limestone, hard; soft streaks

Sand

Limes tone, hard

Rock

Limestone, hard; soft streaks

Rock

Limes tone

$\begin{array}{rl}1 & 675 \\ 5 & 680 \\ 20 & 700 \\ 25 & 725 \\ 2 & 727 \\ 27 & 754 \\ 2 & 756 \\ 5 & 761\end{array}$


Table 3.--Driller's logs of wells in the Fort Rucker area--Continued

\begin{tabular}{|c|c|c|c|c|}
\hline Owner: Town of Newton & - Well 2 & Driller: & Layne-Central Company & \\
\hline & & & $\begin{array}{l}\text { Thickness } \\
(f t)\end{array}$ & $\begin{array}{l}\text { Depth } \\
\text { (ft) }\end{array}$ \\
\hline Red clay & & & 15 & 15 \\
\hline Sand & & & 13 & 28 \\
\hline Sand and gravel & & & 5 & 33 \\
\hline Sand & & & 50 & 83 \\
\hline Clay & & & 6 & 89 \\
\hline Rock & & & 2 & 91 \\
\hline Sandy clay & & & 1 & 92 \\
\hline Rock & & & 2 & 94 \\
\hline Sandy clay and rock & & & 55 & 149 \\
\hline Rock & & & 4 & 153 \\
\hline Sandy clay & & & 34 & 187 \\
\hline Clay & & & 41 & 228 \\
\hline Rock & & & 1 & 229 \\
\hline Clay & & & 2 & 231 \\
\hline Rock & & & 3 & 234 \\
\hline Sandy clay & & & 67 & 301 \\
\hline Rock & & & 2 & 303 \\
\hline Sandy clay & & & 31 & 334 \\
\hline Sand and clay streaks & & & 11 & 345 \\
\hline Clay & & & 20 & 365 \\
\hline Sand and clay & & & 13 & 378 \\
\hline Rock & & & 1 & 379 \\
\hline Sand with clay & & & 21 & 400 \\
\hline Clay with rocks & & & 23 & 423 \\
\hline Clay & & & 4 & 427 \\
\hline Sand with clay & & & 10 & 437 \\
\hline Shale and rocks & & & 43 & 480 \\
\hline Sand with lime & & & 23 & 503 \\
\hline Gravel with lime & & & 22 & 525 \\
\hline Lime with sand & & & 24 & 549 \\
\hline Lime with gravel & & & 23 & 572 \\
\hline Soft lime with clay & & & 22 & 594 \\
\hline Lime and clay & & & 23 & 617 \\
\hline Clay with lime & & & 23 & 640 \\
\hline Clay with lime & & & 5 & 645 \\
\hline Lime & & & 9 & 654 \\
\hline Sand & & & 6 & 660 \\
\hline Rock & & & 5 & 665 \\
\hline Sand with lime breaks & & & 19 & 684 \\
\hline Rock & & & 2 & 686 \\
\hline Sand and rock & & & 2 & 688 \\
\hline Rock & & & 1 & 689 \\
\hline Sand & & & 1 & 690 \\
\hline Rock & & & 15 & 705 \\
\hline Sand and rock & & & 2 & 707 \\
\hline
\end{tabular}


Table 3.--Driller's logs of wells in the Fort Rucker area--Continued

\begin{tabular}{lccc}
\hline & Well 81 & & \\
\hline & $\begin{array}{c}\text { Thickness } \\
\text { (ft) }\end{array}$ & $\begin{array}{c}\text { Depth } \\
\text { (ft) }\end{array}$ \\
\hline Lime and sand & 11 & 718 \\
Lime & 12 & 730 \\
Lime and sand & 3 & 733 \\
Lime & Lime with sand & 7 & 740 \\
Lime & 18 & 758 \\
Lime and sand & 1 & 759 \\
Lime & 3 & 762 \\
& 35 & 797
\end{tabular}


Table 3.--Driller's logs of wells in the Fort Rucker area--Continued

Wel1 83

Owner: Town of Midland City - Well 2 Driller: Layne-Central Company

\begin{tabular}{|c|c|c|}
\hline & $\begin{array}{l}\text { Thickness } \\
\text { (ft) }\end{array}$ & $\begin{array}{l}\text { Depth } \\
\text { (ft) }\end{array}$ \\
\hline Clay, red & 28 & 28 \\
\hline Clay and gravel & 9 & 37 \\
\hline Rock & 6 & 43 \\
\hline Sand, yellow, loose, muddy & 31 & 74 \\
\hline Mud, sandy, loose & 31 & 105 \\
\hline Clay & 3 & 108 \\
\hline Sand & 4 & 112 \\
\hline Clay & 14 & 126 \\
\hline Sand and limestone & 16 & 142 \\
\hline Sand and clay & 16 & 158 \\
\hline Clay, blue & 7 & 165 \\
\hline Rock & 1 & 166 \\
\hline Clay, sandy & 10 & 176 \\
\hline Sand & 12 & 188 \\
\hline Sand & 3 & 191 \\
\hline Sand and limestone & 23 & 214 \\
\hline Clay; limestone streaks & 50 & 264 \\
\hline Rock & 2 & 266 \\
\hline Clay & 34 & 300 \\
\hline Rock, hard & 1 & 301 \\
\hline Clay & 72 & 373 \\
\hline Clay, sand streaks & 17 & 390 \\
\hline Limestone, hard & 7 & 397 \\
\hline Limestone, hard; and sand & 41 & 438 \\
\hline Limestone; streaks shale & 68 & 506 \\
\hline Shale, sandy; limestone breaks & 18 & 524 \\
\hline Limes tone & 128 & 652 \\
\hline Sand, packed & 14 & 666 \\
\hline Limestone & 3 & 669 \\
\hline Sand, packed & 13 & 682 \\
\hline Limestone & 2 & 684 \\
\hline Limestone; streaks sand & 48 & 732 \\
\hline Sand & 3 & 735 \\
\hline Rock & 2 & 737 \\
\hline Sand & 6 & 743 \\
\hline Rock & 2 & 745 \\
\hline Sand & 9 & 754 \\
\hline Limestone; sand breaks & - & - \\
\hline
\end{tabular}


Table 3.--Driller's logs of wells in the Fort Rucker area--Continued

\begin{tabular}{|c|c|c|c|}
\hline ner: Town of Midland City & $\begin{array}{l}\text { Well } 84 \\
\text { - Well } 1\end{array}$ & Layne-Central Company & \\
\hline & & $\begin{array}{l}\text { Thickness } \\
\text { (ft) }\end{array}$ & $\begin{array}{l}\text { Depth } \\
\text { (ft) }\end{array}$ \\
\hline Sandy clay & & 8 & 8 \\
\hline Clay & & 42 & 50 \\
\hline Sand & & 14 & 64 \\
\hline Sand & & 21 & 85 \\
\hline Sand & & 22 & 107 \\
\hline Sand & & 9 & 116 \\
\hline Sand, streaks clay & & 12 & 128 \\
\hline Sand, breaks small clay & & 20 & 148 \\
\hline Clay & & 16 & 164 \\
\hline Sand, fine & & 5 & 169 \\
\hline Rock, hard & & 1 & 170 \\
\hline Sand, fine & & 4 & 174 \\
\hline Sandy clay & & 17 & 191 \\
\hline Soft lime rock & & 7 & 198 \\
\hline Soft breaks lime rock & & 19 & 217 \\
\hline Shale & & 11 & 228 \\
\hline Lime rock & & 9 & 237 \\
\hline Sand and shale & & 15 & 252 \\
\hline Rock & & 13 & 265 \\
\hline Shale & & 110 & 375 \\
\hline Green sand, lime rock breaks & & 20 & 395 \\
\hline Sand and rock & & 22 & 417 \\
\hline Rock & & 15 & 432 \\
\hline Sand, no good & & 7 & 439 \\
\hline Rock and clay & & 53 & 492 \\
\hline Rock & & 15 & 507 \\
\hline Sand & & 3 & 510 \\
\hline Rock & & 4 & 514 \\
\hline Sand & & 5 & 519 \\
\hline Rock & & 3 & 522 \\
\hline Sand & & 1 & 523 \\
\hline Rock & & 1 & 524 \\
\hline Sand & & 9 & 533 \\
\hline Rock & & 1 & 534 \\
\hline Soft sandy lime rock & & 18 & 552 \\
\hline Soft sandy lime rock & & 22 & 574 \\
\hline Soft sandy lime rock & & 21 & 595 \\
\hline
\end{tabular}


Table 3.--Driller's logs of wells in the Fort Rucker area--Continued

\begin{tabular}{|c|c|}
\hline \multicolumn{2}{|c|}{ Well 85} \\
\hline & $\begin{array}{l}\text { Depth } \\
\text { (ft) }\end{array}$ \\
\hline Top soil & 2 \\
\hline Red clay & 27 \\
\hline Soft pipe clay & 57 \\
\hline Muddy sand & 104 \\
\hline Sandy clay & 120 \\
\hline Sand & 138 \\
\hline Sandy clay & 192 \\
\hline Soft rock & 200 \\
\hline Sandy clay and rock breaks & 222 \\
\hline Sandy clay and rock breaks & 238 \\
\hline Lime rock and clay breaks & 248 \\
\hline Hard clay and lime streaks & 259 \\
\hline Hard lime rock & 264 \\
\hline Hard clay and lime rock streaks & 276 \\
\hline Sandy clay and lime breaks & 293 \\
\hline Sandy clay & 315 \\
\hline Sandy clay & 330 \\
\hline Hard clay & 387 \\
\hline Lime rock and sand breaks & 406 \\
\hline Green sand and lime breaks & 428 \\
\hline Sand and lime streaks & 451 \\
\hline Sand and lime streaks & 473 \\
\hline Clay and lime streaks & 496 \\
\hline Clay and lime streaks & 512 \\
\hline Lime rock & 520 \\
\hline Lime rock & 541 \\
\hline Lime rock & 553 \\
\hline Sand and lime rock & 563 \\
\hline Lime and clay breaks & 578 \\
\hline Lime rock & 587 \\
\hline Lime rock & 609 \\
\hline Lime rock & 632 \\
\hline Lime rock & 655 \\
\hline Hard lime rock & 678 \\
\hline Lime rock & 687 \\
\hline Sand and rock breaks & 698 \\
\hline Lime and lime breaks & 712 \\
\hline Lime rock & 716 \\
\hline Sand and lime breaks & 720 \\
\hline Hard sand and lime breaks & 742 \\
\hline Hard sand and lime breaks & 765 \\
\hline
\end{tabular}


Table 3.--Driller's logs of wells in the Fort Rucker area--Continued

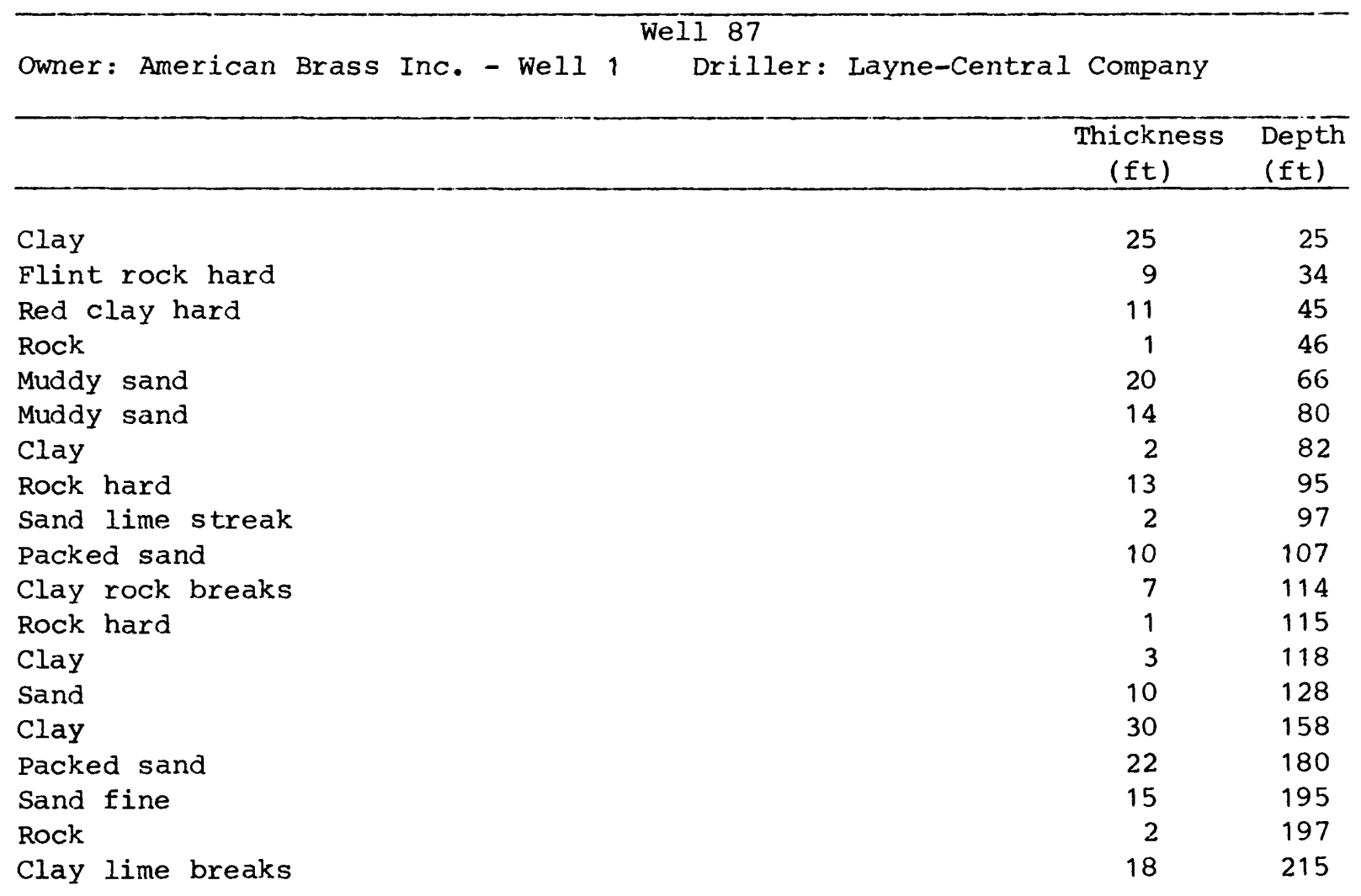


Table 3.--Driller's logs of wells in the Fort Rucker area--Continued

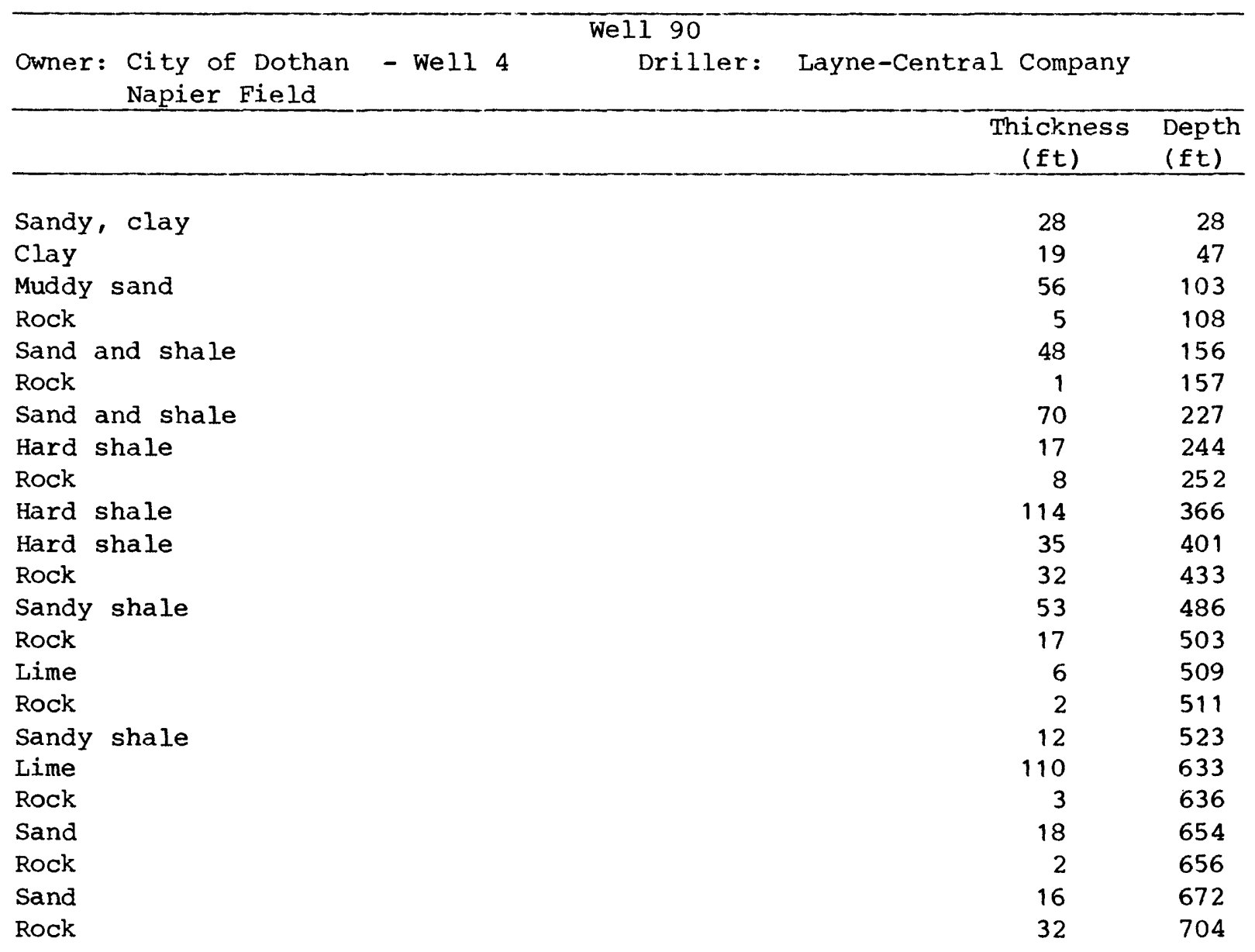


Table 3.--Driller's logs of wells in the Fort Rucker area--Continued

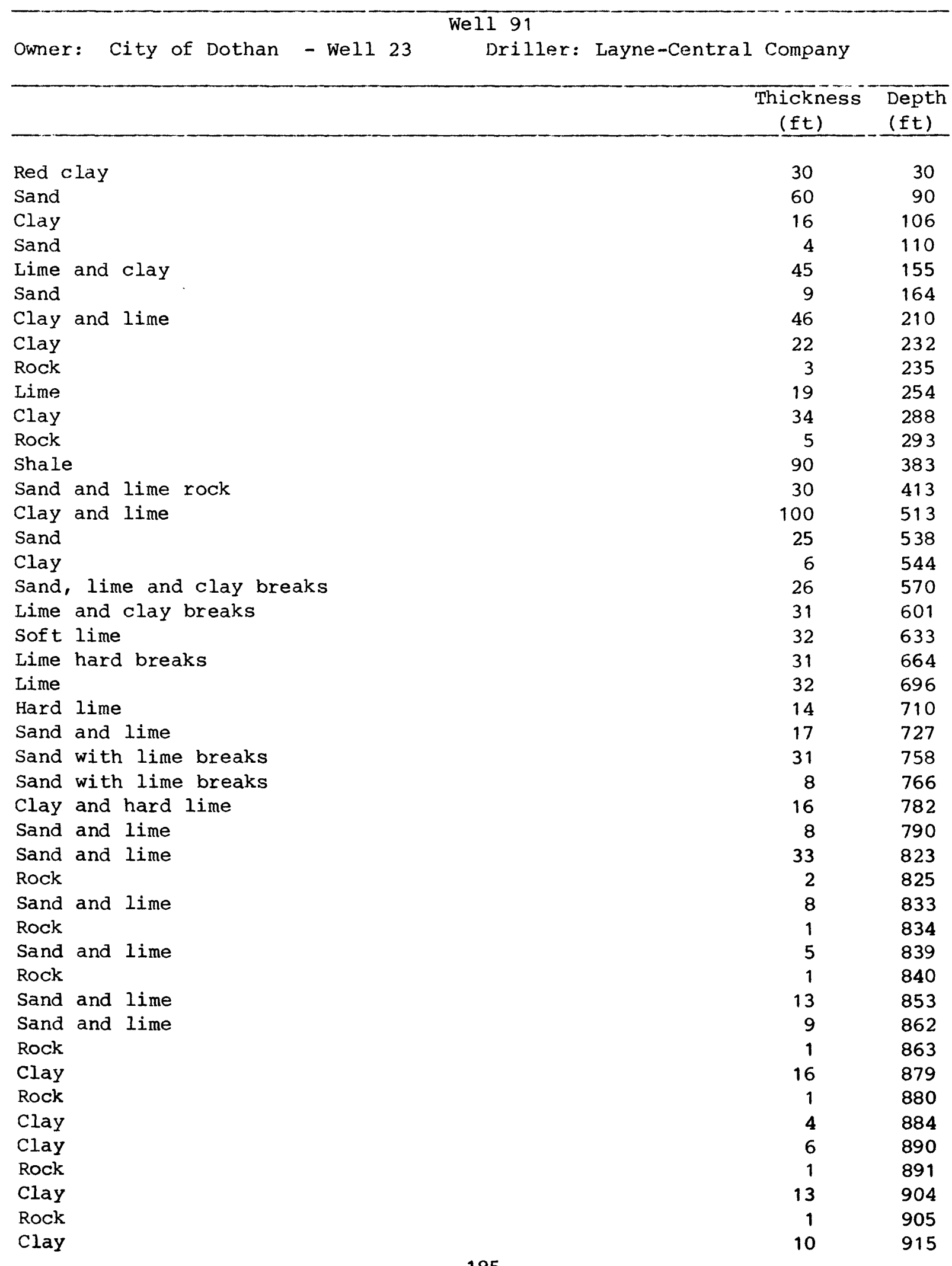


Table 3.--Driller's logs of wells in the Fort Rucker area--Continued

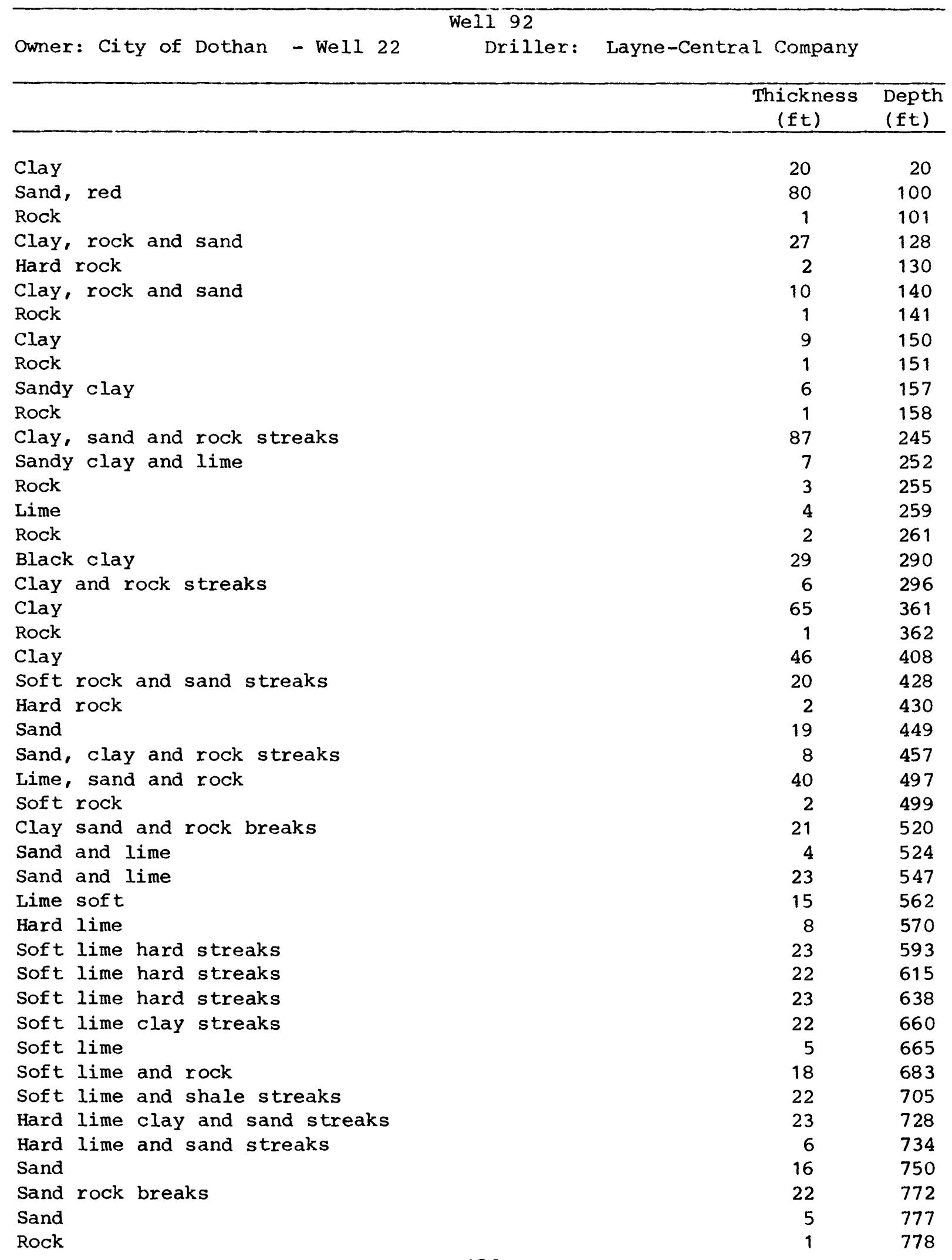


Table 3.--Driller's logs of wells in the Fort Rucker area--Continued

We11 92

$\begin{array}{cl}\text { Thickness } & \text { Depth } \\ (f t) & (f t)\end{array}$

ft)

Sand

Rock

$6 \quad 784$

$6 \quad 790$

Sand

$4 \quad 794$

Sand streaks of lime

22

816

Sand streaks of lime

$15 \quad 831$

Rock sand and clay streaks

7

831

Rock sand and clay streaks

22

860 
Table 3.--Driller's logs of wells in the Fort Rucker area--Continued

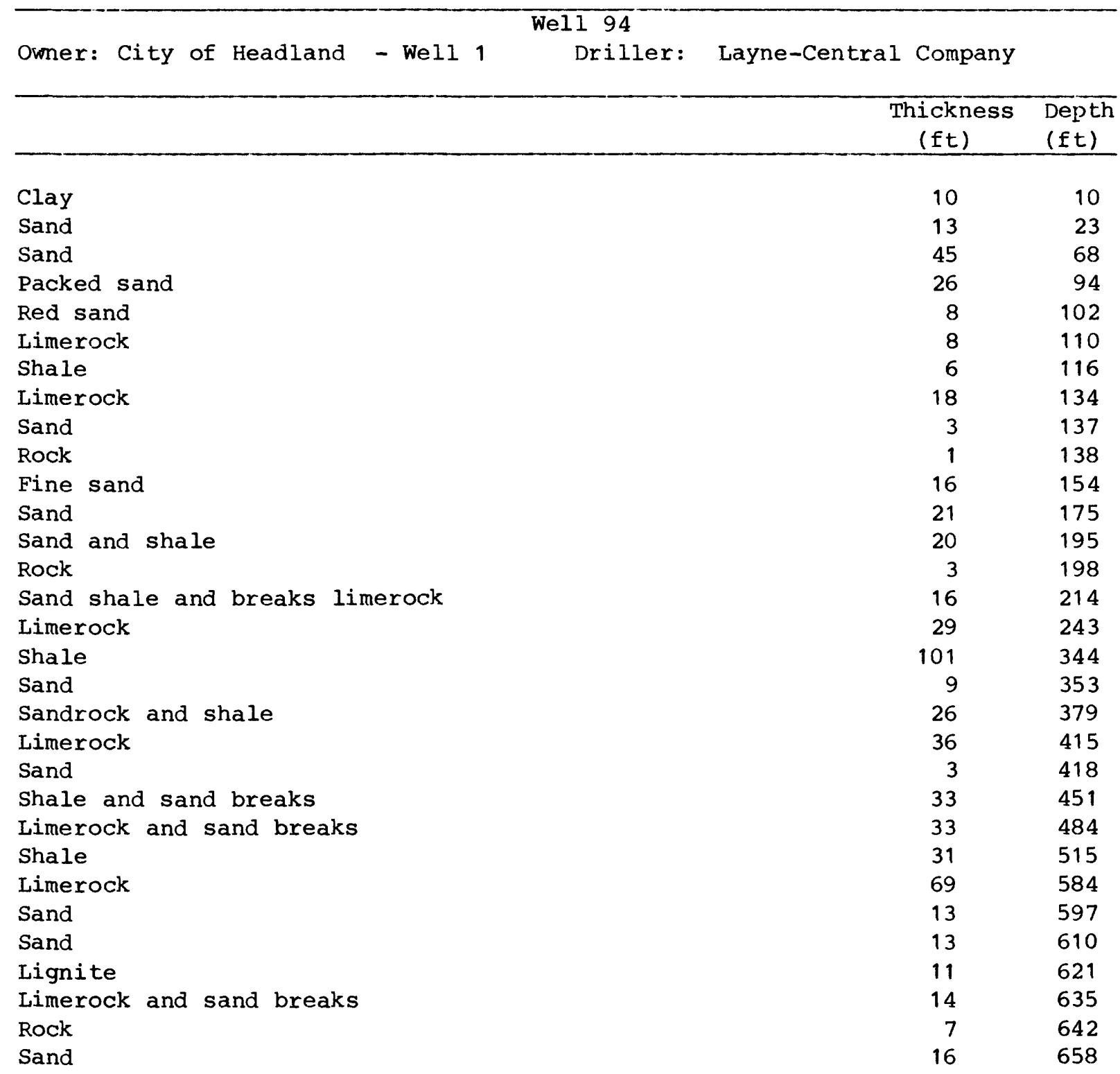


Table 3.--Driller's logs of wells in the Fort Rucker area--Continued

\begin{tabular}{|c|c|c|c|}
\hline \multirow[b]{2}{*}{ Owner: City of Headland } & \multicolumn{2}{|l|}{ We11 95} & \multirow{3}{*}{$\begin{array}{c}\cdot \\
\begin{array}{l}\text { Depth } \\
\text { (ft) }\end{array}\end{array}$} \\
\hline & - Well 2 Drillex: & Layne-Central Company & \\
\hline & & $\begin{array}{l}\text { Thickness } \\
(\mathrm{ft})\end{array}$ & \\
\hline Clay & & 19 & 19 \\
\hline Sand & & 19 & 38 \\
\hline Clay & & 6 & 44 \\
\hline Sand and gravel & & 38 & 82 \\
\hline Rock & & 2 & 84 \\
\hline Sand & & 13 & 97 \\
\hline Rock & & 3 & 100 \\
\hline Lime & & 31 & 131 \\
\hline Clay & & 56 & 187 \\
\hline Clay & & 14 & 201 \\
\hline Clay and sand & & 24 & 225 \\
\hline Clay & & 19 & 244 \\
\hline Rock & & 2 & 246 \\
\hline Lime & & 7 & 253 \\
\hline Rock & & 2 & 255 \\
\hline Sand and clay & & 54 & 309 \\
\hline Shale & & 51 & 360 \\
\hline Shale and sand & & 25 & 385 \\
\hline Lime and sand & & 10 & 395 \\
\hline Lime rock & & 6 & 401 \\
\hline Lime and sand & & 8 & 409 \\
\hline Lime rock & & 11 & 420 \\
\hline Sand & & 5 & 425 \\
\hline Sand & & 6 & 431 \\
\hline Clay & & 8 & 439 \\
\hline Lime, hard & & 4 & 443 \\
\hline Clay & & 12 & 455 \\
\hline Lime and clay & & 34 & 489 \\
\hline Sandy clay & & 11 & 500 \\
\hline Clay & & 4 & 504 \\
\hline Sandy clay & & 8 & 512 \\
\hline Lime & & 29 & 541 \\
\hline Lime & & 23 & 564 \\
\hline Lime & & 22 & 586 \\
\hline Lime & & 22 & 608 \\
\hline Lime & & 12 & 620 \\
\hline Lime & & 11 & 631 \\
\hline Lime & & 22 & 653 \\
\hline Lime & & 4 & 657 \\
\hline Sand & & 10 & 667 \\
\hline Lime & & 1 & 668 \\
\hline Sand & & 5 & 673 \\
\hline Lime & & 3 & 676 \\
\hline Lime & & 9 & 685 \\
\hline Lime & & 3 & 688 \\
\hline Lime & & 3 & 691 \\
\hline Lime & & 3 & 694 \\
\hline Sand and lime & & 5 & 699 \\
\hline Lime & 189 & 11 & 710 \\
\hline
\end{tabular}


Table 3.--Driller's logs of wells in the Fort Rucker area--Continued

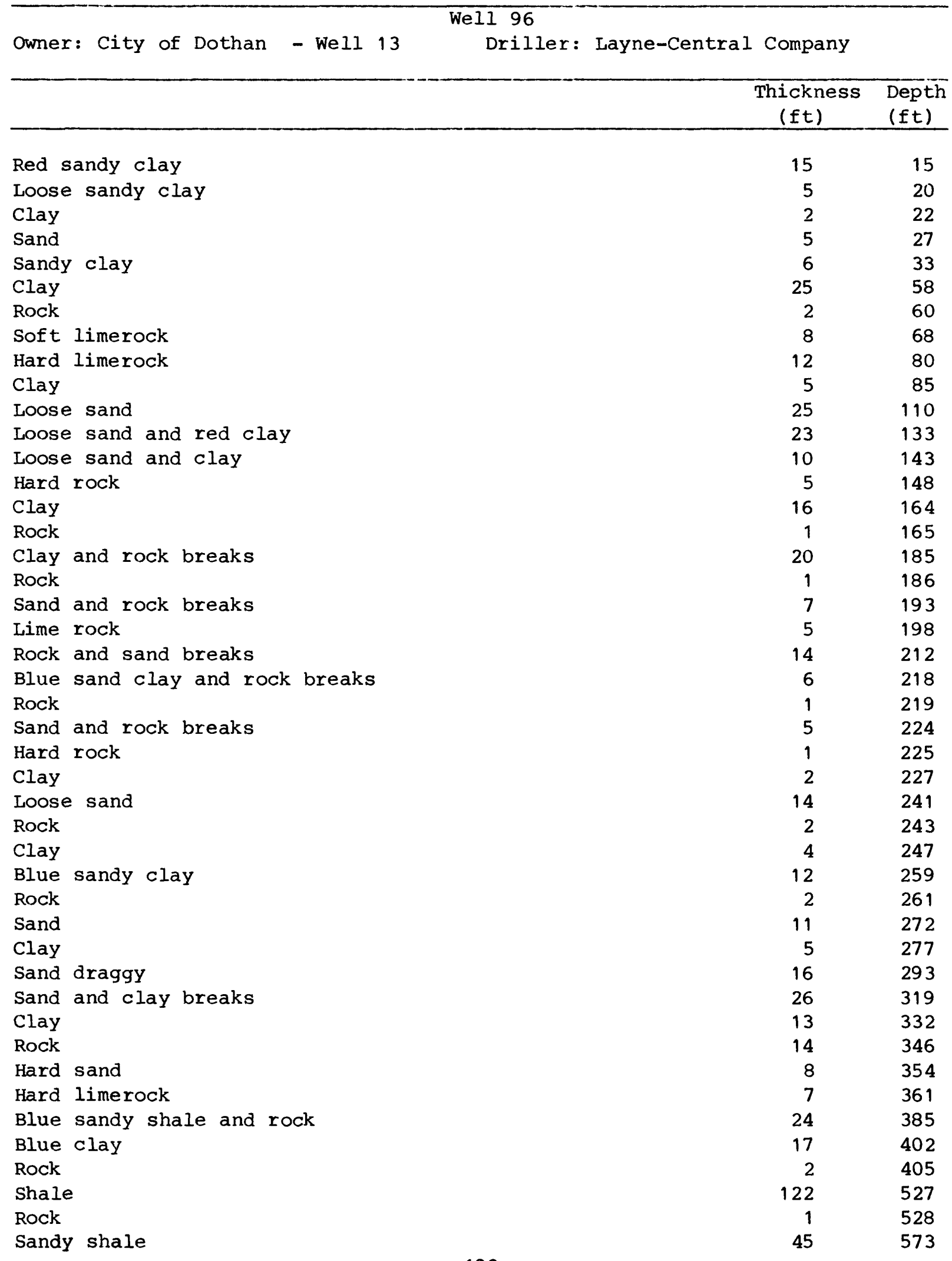


Table 3.--Driller's logs of wells in the Fort Rucker area--Continued

\begin{tabular}{lrr}
\hline & Well 96 & \\
& $\begin{array}{r}\text { Thickness } \\
\text { (ft) }\end{array}$ & $\begin{array}{c}\text { Depth } \\
\text { (ft) }\end{array}$ \\
\hline & & \\
Sand and streaks shale & 12 & 585 \\
Hard blue sand & 10 & 595 \\
Hard blue sand and rock breaks & 19 & 614 \\
Hard gray sand and rock breaks & 23 & 637 \\
Sand and sand rock breaks, bottom limestone cut better & 28 & 665 \\
Gray packed sand & 8 & 673 \\
Lime rock & 2 & 675 \\
Packed sand, limerock breaks & 7 & 682 \\
Packed sand fine & 10 & 692 \\
Limerock & 3 & 695 \\
Packed sand fine & 9 & 704 \\
Sand and rock breaks, rock 3 to 5 ft apart & 19 & 723 \\
Clay & 5 & 728 \\
Sand, clay, limerock & 22 & 750 \\
Limerock, hard and soft streaks & 100 & 850 \\
Hard rock & 20 & 870 \\
Hard shale & 18 & 888 \\
Rock and clay breaks & 23 & 911
\end{tabular}


Table 3.--Driller's logs of wells in the Fort Rucker area--Continued

\begin{tabular}{|c|c|c|c|}
\hline \multicolumn{4}{|c|}{ Well 97} \\
\hline Owner: City of Dothan - Well 14 & Driller: & Layne-Central Company & \\
\hline & & $\begin{array}{c}\text { Thickness } \\
(\mathrm{ft})\end{array}$ & $\begin{array}{l}\text { Depth } \\
(\mathrm{ft})\end{array}$ \\
\hline Clay & & 9 & 9 \\
\hline Soft sand & & 15 & 24 \\
\hline Clay & & 31 & 55 \\
\hline Limes tone & & 7 & 62 \\
\hline Sand & & 3 & 65 \\
\hline Sand & & 23 & 88 \\
\hline Clay & & 2 & 90 \\
\hline Sand & & 8 & 98 \\
\hline Clay & & 12 & 110 \\
\hline Sand and clay & & 32 & 142 \\
\hline Clay, sand and gravel & & 30 & 172 \\
\hline Clay and sand & & 15 & 187 \\
\hline Sand & & 90 & 277 \\
\hline Limerock & & 3 & 280 \\
\hline Sand & & 11 & 291 \\
\hline Lime rock & & 6 & 297 \\
\hline Sand & & 17 & 314 \\
\hline Limerock and clay & & 23 & 337 \\
\hline Sand, clay and limestone & & 24 & 361 \\
\hline Limestone and sand & & 6 & 367 \\
\hline Sand and limestone & & 27 & 394 \\
\hline Limestone & & 22 & 416 \\
\hline Limestone & & 13 & 429 \\
\hline Limes tone & & 13 & 442 \\
\hline Limestone & & 63 & 505 \\
\hline Clay & & 195 & 700 \\
\hline Sand & & 12 & 712 \\
\hline Limerock & & 5 & 717 \\
\hline Sand & & 13 & 730 \\
\hline Limerock & & 1 & 731 \\
\hline Sand & & 17 & 748 \\
\hline Limerock & & 1 & 749 \\
\hline Limerock and sand & & 23 & 772 \\
\hline Limerock and sand & & 23 & 795 \\
\hline Limerock and sand & & 23 & 818 \\
\hline Limestone and sand and clay & & 23 & 841 \\
\hline Shale and lime & & 69 & 910 \\
\hline
\end{tabular}


Table 3.--Driller's logs of wells in the Fort Rucker area--Continued

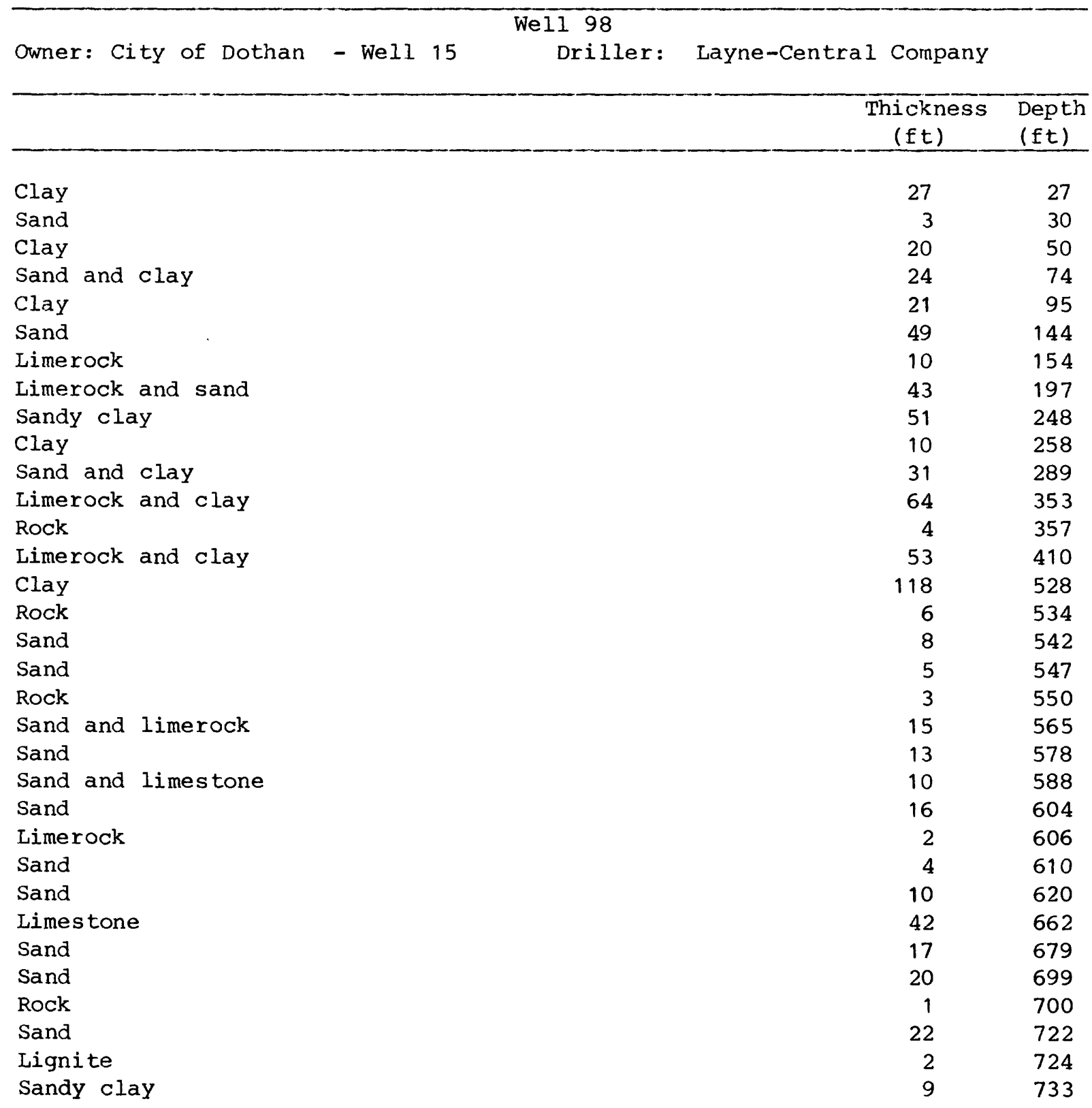


Table 3.--Driller's logs of wells in the Fort Rucker area--Continued

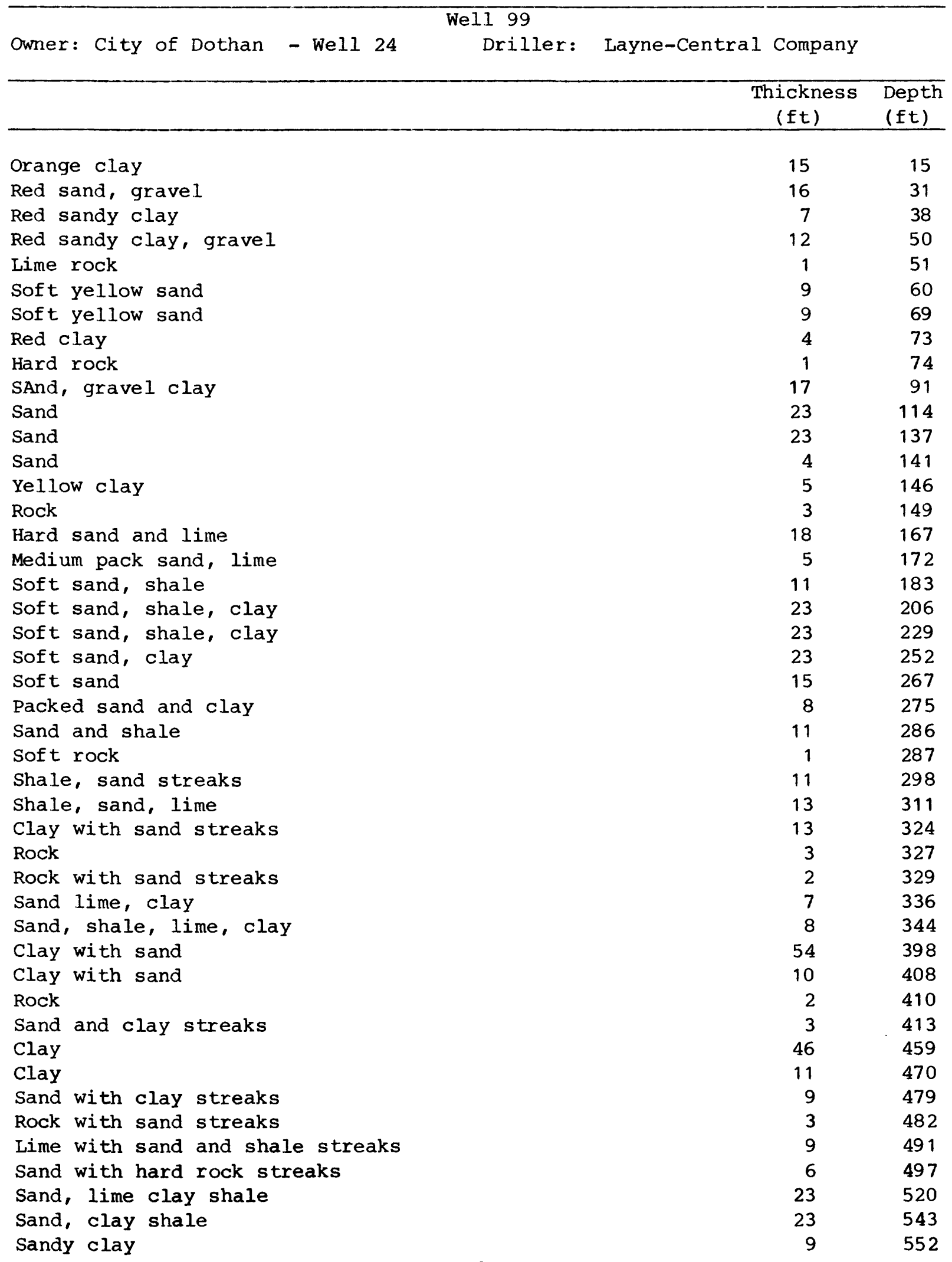


Table 3.--Driller's logs of wells in the Fort Rucker area--Continued

\begin{tabular}{|c|c|c|}
\hline & $\begin{array}{l}\text { Thickness } \\
\text { (ft) }\end{array}$ & $\begin{array}{l}\text { Depth } \\
\text { (ft) }\end{array}$ \\
\hline Rock & 1 & 553 \\
\hline Clay & 12 & 565 \\
\hline Clay & 6 & 571 \\
\hline Sandy lime & 17 & 588 \\
\hline Sandy lime & 9 & 597 \\
\hline Lime & 7 & 604 \\
\hline Lime & 7 & 611 \\
\hline Soft lime & 10 & 621 \\
\hline Hard lime & 12 & 633 \\
\hline White lime & 23 & 656 \\
\hline Soft sand, gravel clay & 9 & 665 \\
\hline Sand with hard streaks clay & 14 & 679 \\
\hline Hard sand, lime, clay & 22 & 701 \\
\hline Hard lime & 23 & 724 \\
\hline Hard lime & 13 & 737 \\
\hline Hard lime & 9 & 746 \\
\hline Hard lime, soft streaks & 23 & 769 \\
\hline Medium lime, hard streaks & 17 & 786 \\
\hline Hard lime & 6 & 792 \\
\hline Hard lime & 7 & 799 \\
\hline Medium lime, hard streaks & 11 & 810 \\
\hline Soft lime, hard streaks & 5 & 815 \\
\hline Hard lime & 6 & 821 \\
\hline Sand with lime & 16 & 837 \\
\hline Sand with lime & 6 & 843 \\
\hline Sand with hard lime & 3 & 846 \\
\hline Sand with lime & 14 & 860 \\
\hline Sand with lime & 7 & 867 \\
\hline Hard lime & 5 & 872 \\
\hline Sand, lime & 6 & 878 \\
\hline Hard lime-sand & 5 & 883 \\
\hline Sand with hard lime & 22 & 905 \\
\hline Sand with hard lime & 14 & 919 \\
\hline Hard rock & 5 & 924 \\
\hline Sandy lime & 4 & 928 \\
\hline Sand with rock & 22 & 950 \\
\hline Sand with rock & 16 & 966 \\
\hline Sand and lime & 6 & 972 \\
\hline Hard sand, lime & 23 & 995 \\
\hline Hard sand, lime & 22 & 1017 \\
\hline Hard sand, lime & 10 & 1027 \\
\hline
\end{tabular}


Table 3.--Driller's logs of wells in the Fort Rucker area--Continued

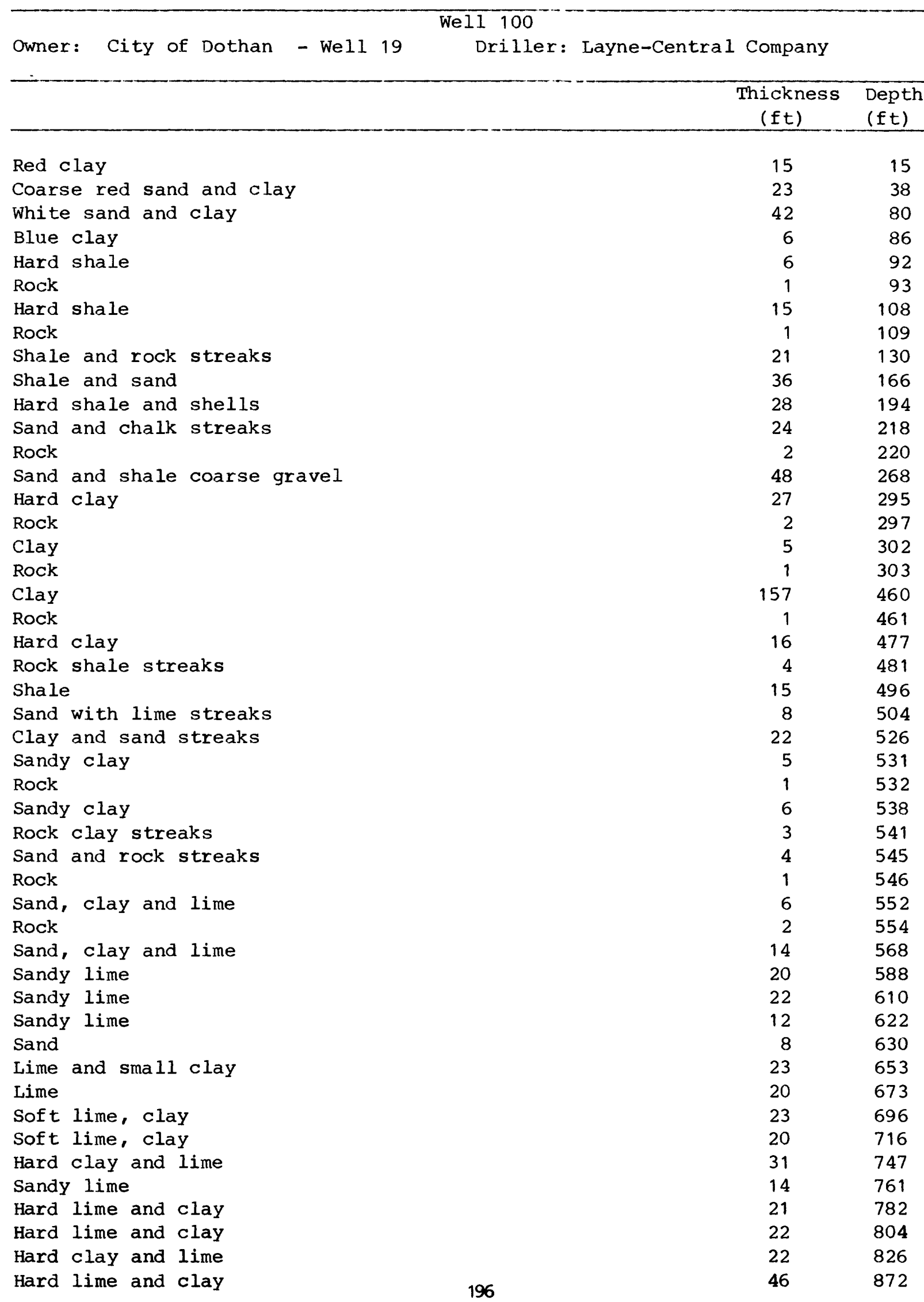


Table 3.--Driller's logs of wells in the Fort Rucker area--Continued

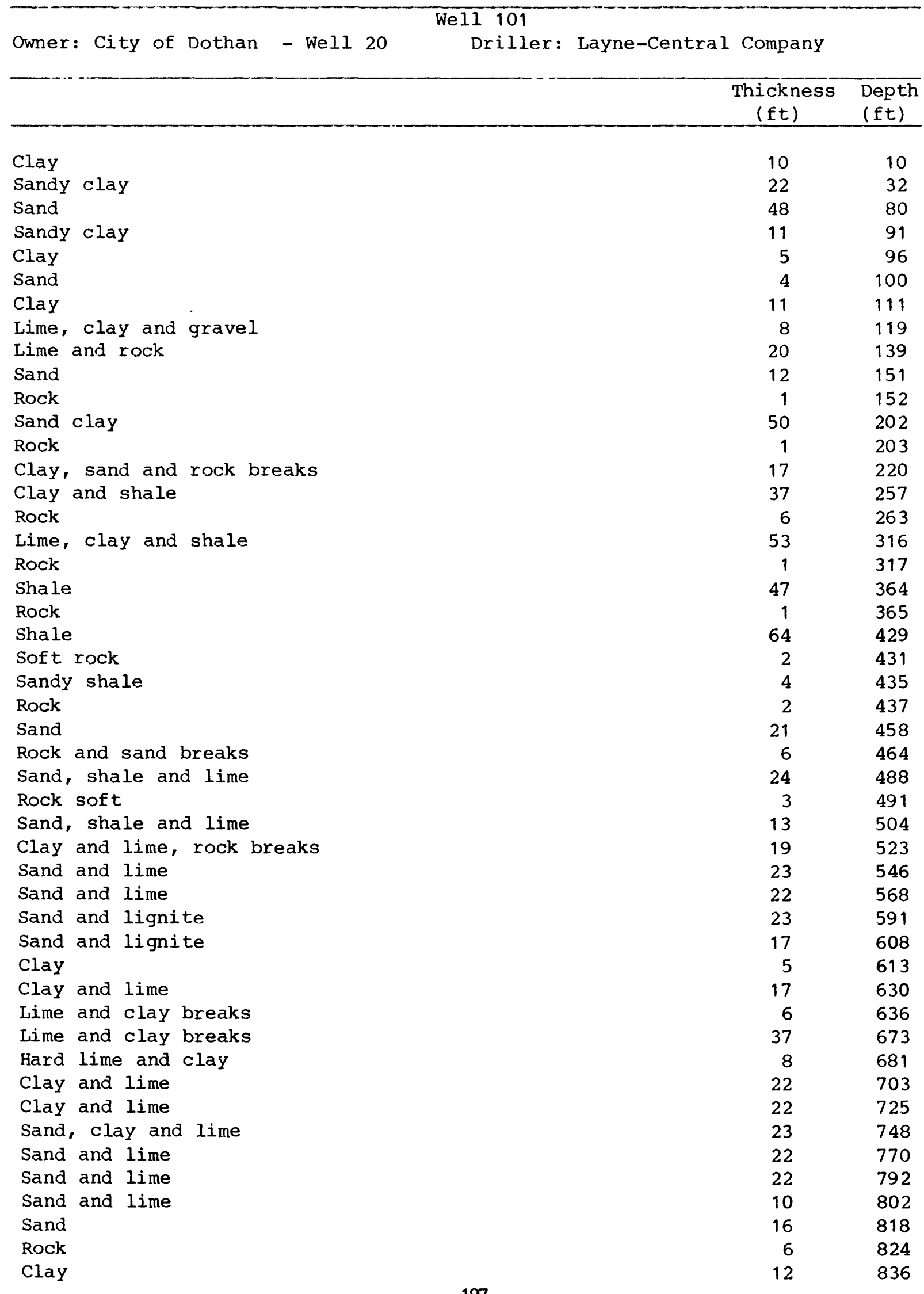


Table 3.--Driller's logs of wells in the Fort Rucker area--Continued

\begin{tabular}{|c|c|c|}
\hline \multirow{3}{*}{ Owner: City of Dothan } & \multirow{2}{*}{\multicolumn{2}{|c|}{ Layne-Central Company }} \\
\hline & & \\
\hline & $\begin{array}{l}\text { Thickness } \\
\text { (ft) }\end{array}$ & $\begin{array}{l}\text { Depth } \\
\text { (ft) }\end{array}$ \\
\hline Top soil & 1 & 1 \\
\hline Red clay & 16 & 17 \\
\hline Firm sand, small clay streaks & 9 & 26 \\
\hline Clay & 3 & 29 \\
\hline Loose sand & 57 & 86 \\
\hline Lime rock, hard & 1 & 87 \\
\hline Hard sand with lime & 8 & 95 \\
\hline Hard lime & 1 & 96 \\
\hline Coarse sand and lime & 7 & 103 \\
\hline Sand & 7 & 110 \\
\hline Hard rock & 1 & 111 \\
\hline Clay & 2 & 113 \\
\hline Soft sandy clay & 8 & 121 \\
\hline Rock & 1 & 122 \\
\hline Hard clay & 9 & 131 \\
\hline Hard packed coarse sand, fine gravel & 28 & 159 \\
\hline Sand, fine gravel, lime and green clay & 32 & 191 \\
\hline Rock, lime & 4 & 195 \\
\hline Coarse sand, lime and clay & 35 & 230 \\
\hline Gummy clay & 6 & 236 \\
\hline Sand and lime & 4 & 240 \\
\hline Gummy clay & 7 & 247 \\
\hline Hard rock & 11 & 258 \\
\hline Sand lime and shale & 15 & 273 \\
\hline Sand lime and shale (hard) & 49 & 322 \\
\hline Hard sand, some clay and rock & 41 & 363 \\
\hline Hard clay and rock & 45 & 408 \\
\hline Hard clay, rock and sand & 23 & 431 \\
\hline Sand, rock and clay, hard & 45 & 476 \\
\hline Sand with clay & 12 & 488 \\
\hline Sand lime and clay streaks, hard & 68 & 556 \\
\hline Soft lime & 4 & 560 \\
\hline Hard lime, soft streaks & 75 & 635 \\
\hline Soft lime & 11 & 646 \\
\hline Hard lime & 12 & 658 \\
\hline Hard lime, soft streaks (clay) & 22 & 680 \\
\hline Hard lime, brittle & 22 & 702 \\
\hline Hard lime, soft streaks (clay) & 22 & 724 \\
\hline Hard lime & 7 & 731 \\
\hline Packed sand, with lime, little clay & 16 & 747 \\
\hline Packed sand with lime, little clay & 22 & 769 \\
\hline Packed sand with lime, small clay streaks & 18 & 787 \\
\hline Hard rock (4 in.) & 1 & 788 \\
\hline Sand & 2 & 790 \\
\hline Packed sand and clay streaks & 8 & 798 \\
\hline
\end{tabular}


Table 3.--Driller's logs of wells in the Fort Rucker area--Continued

\begin{tabular}{lrr}
\hline & Well 102 & \\
\hline & $\begin{array}{c}\text { Thickness } \\
\text { (ft) }\end{array}$ & $\begin{array}{c}\text { Depth } \\
\text { (ft) }\end{array}$ \\
\hline Rock (2 in.) & 1 & 799 \\
Packed sand and clay streaks & 7 & 806 \\
Rock (2 in.) & 1 & 807 \\
Packed sand and clay streaks & 5 & 812 \\
Packed sand & 3 & 815 \\
(Hard) rock & 2 & 817 \\
Sand and clay & 6 & 823 \\
Lime rock, hard & 3 & 826 \\
Soft lime, some clay & 7 & 833 \\
Lime rock, hard & 1 & 834 \\
Soft lime, some clay & 1 & 835 \\
Soft lime & 2 & 837 \\
Lime rock, hard & 1 & 838 \\
Lime, sandy, some clay & 20 & 858 \\
Lime, sandy, some clay & 9 & 867 \\
Lime rock (extra hard) & 4 & 871 \\
Medium lime & 10 & 881 \\
Hard sandy lime & 23 & 904 \\
Hard sandy lime & 23 & 927 \\
Hard sandy lime & 23 & 950
\end{tabular}


Table 3.--Driller's logs of wells in the Fort Rucker area--Continued

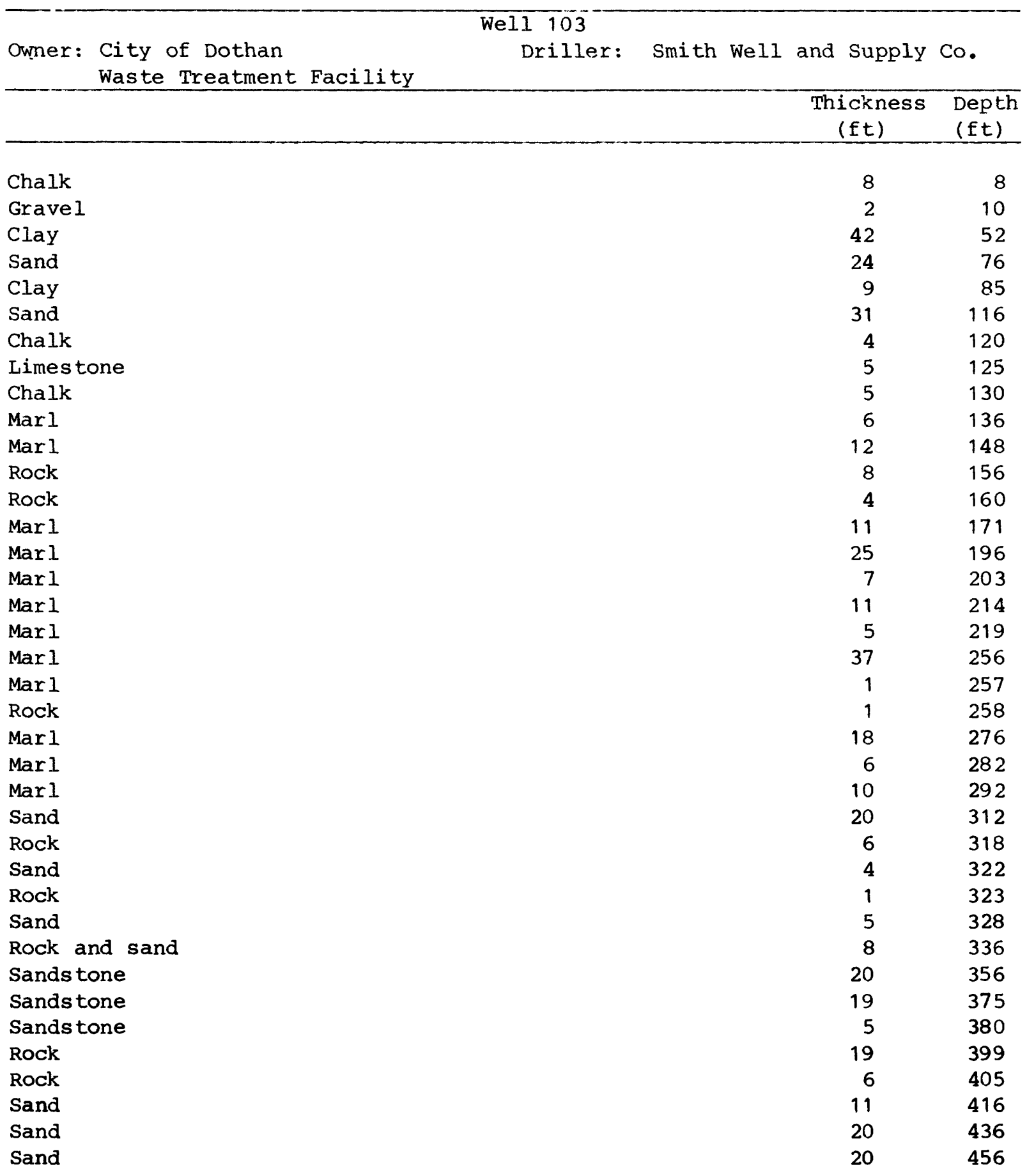


Table 3.--Driller's logs of wells in the Fort Rucker area--Continued

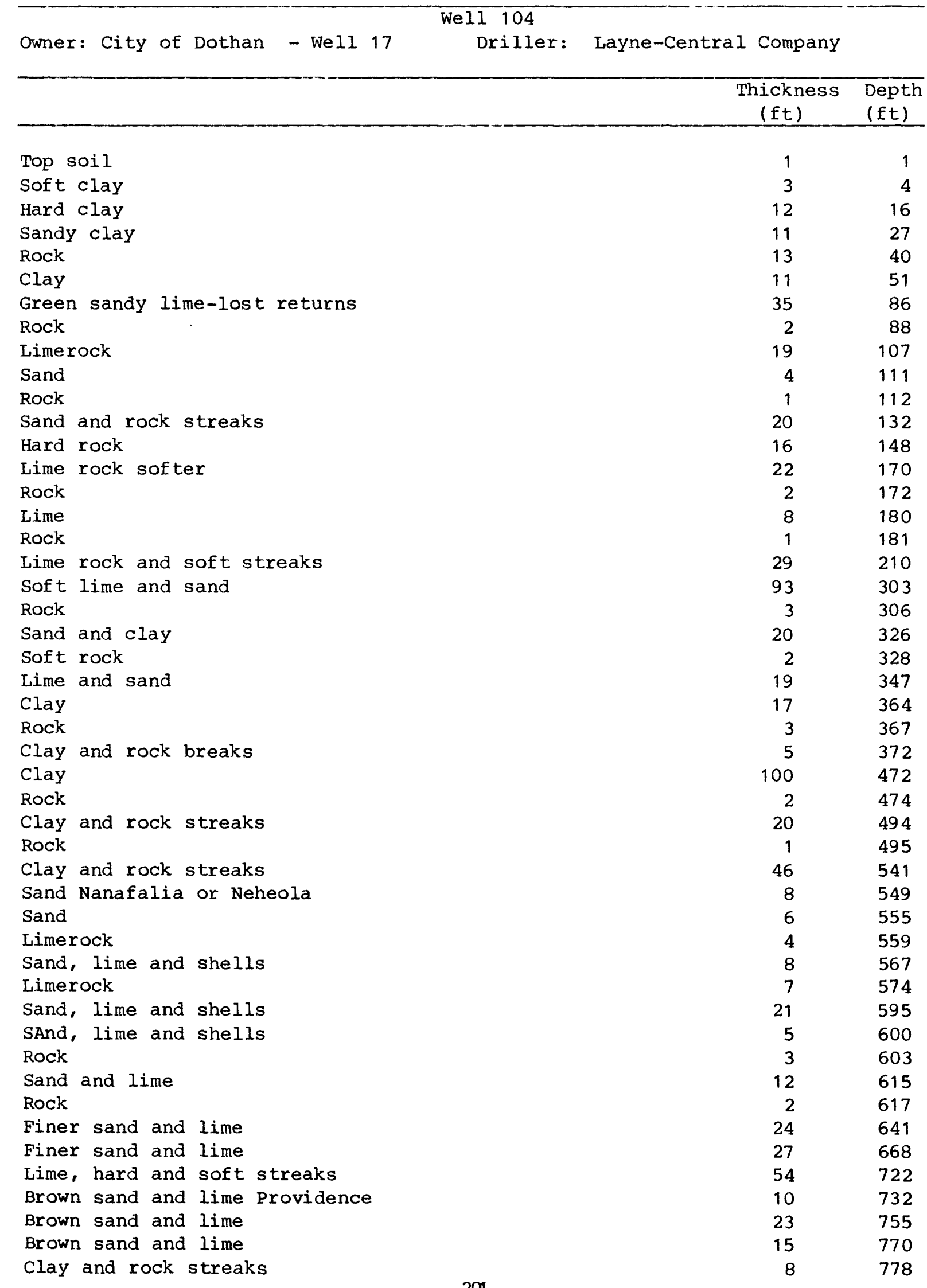


Table 3.--Driller's logs of wells in the Fort Rucker area--Continued

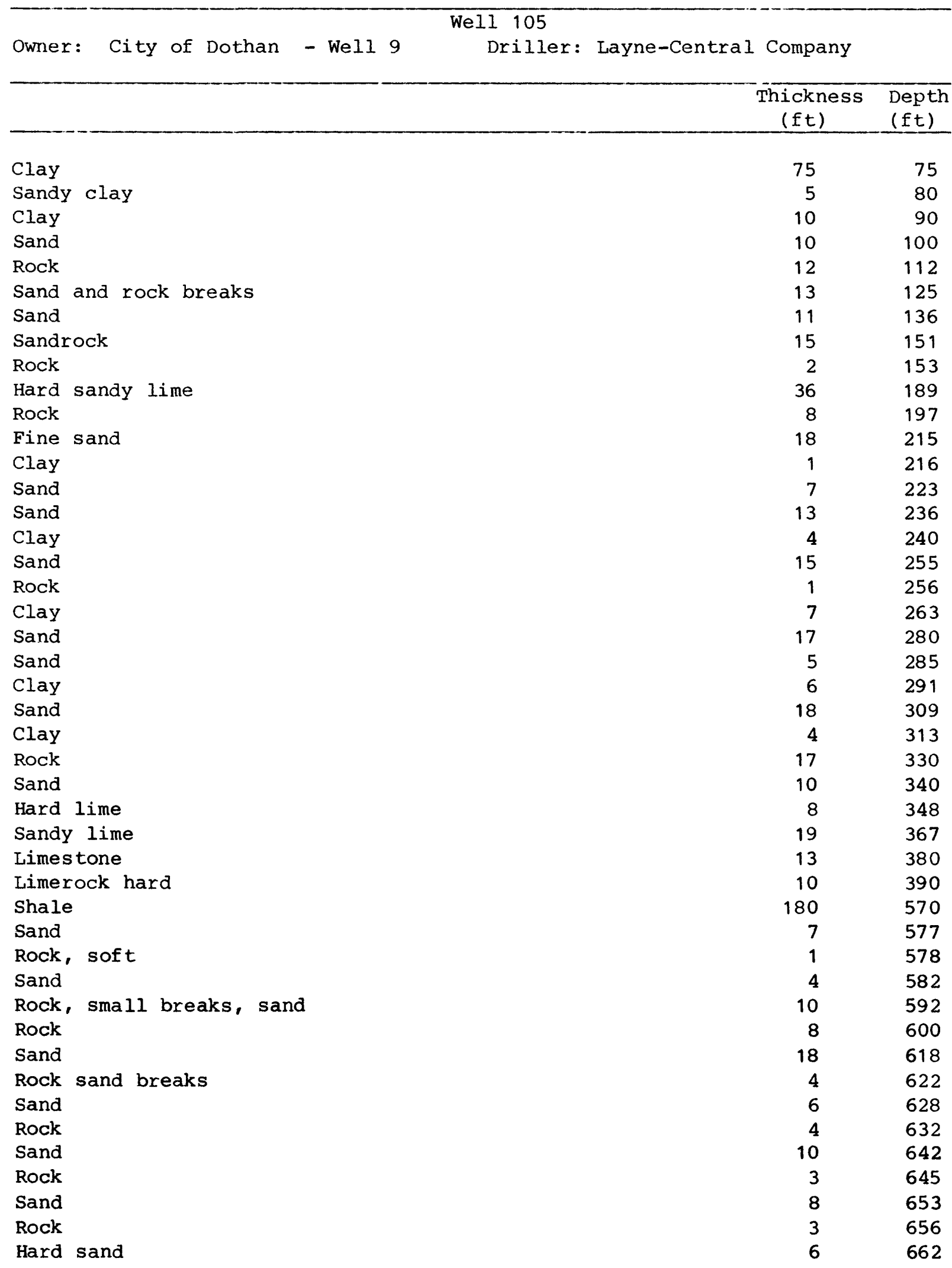


Table 3.--Driller's logs of wells in the Fort Rucker area--Continued

Well 105

\begin{tabular}{lrr}
\hline & $\begin{array}{c}\text { Thickness } \\
\text { (ft) }\end{array}$ & $\begin{array}{c}\text { Depth } \\
\text { (ft) }\end{array}$ \\
\hline Rock & & \\
Hard sand & 2 & 664 \\
Rock & 4 & 668 \\
Sand, three small boulders & 2 & 670 \\
Sand & 21 & 691 \\
Limerock & 5 & 696 \\
Pack sand & 54 & 750 \\
Clay & 40 & 790 \\
Hard rock & 35 & 825 \\
Rock & 10 & 835 \\
\end{tabular}


Table 3.--Driller's logs of wells in the Fort Rucker area--Continued

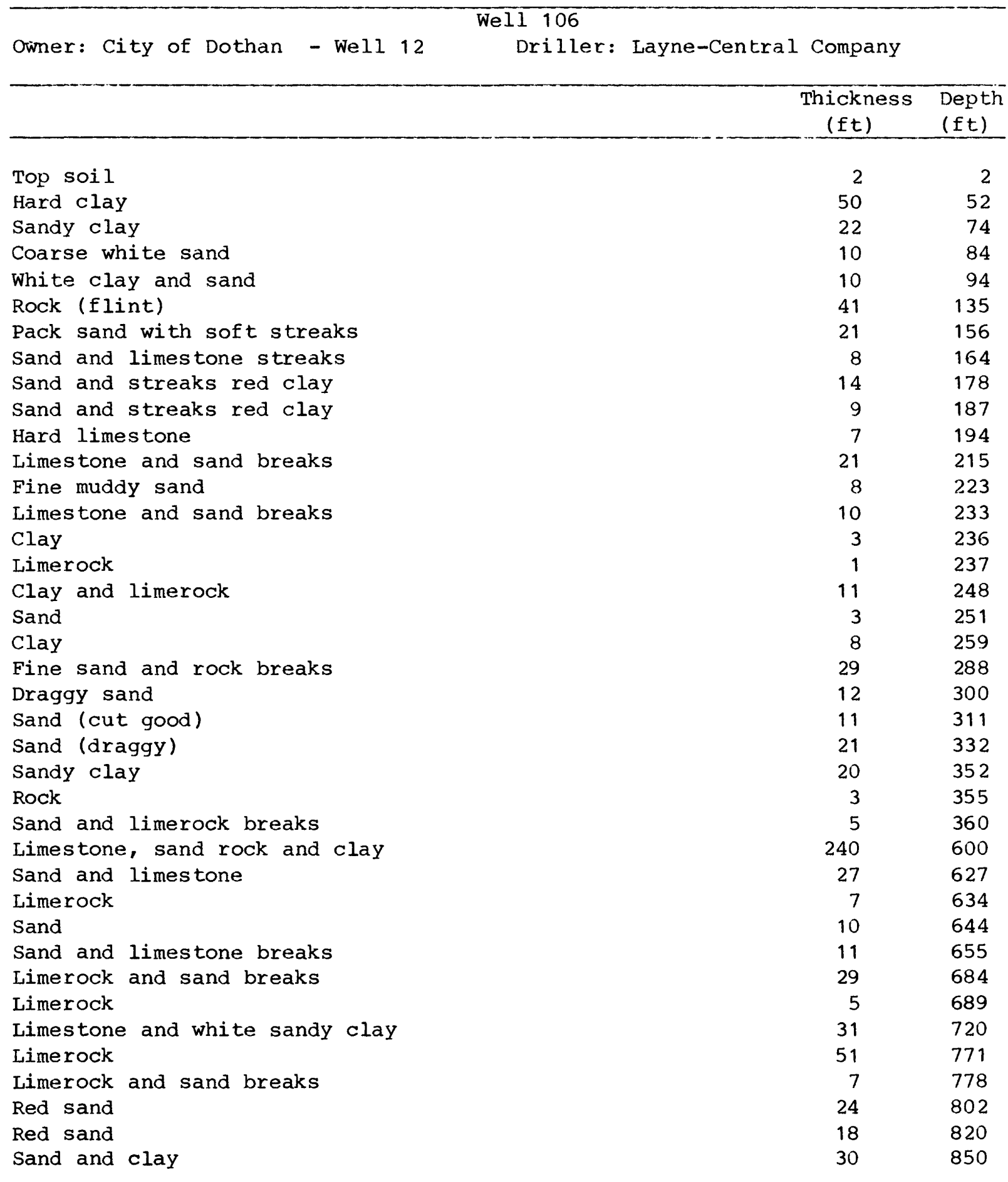


Table 3.--Driller's logs of wells in the Fort Rucker area--Continued

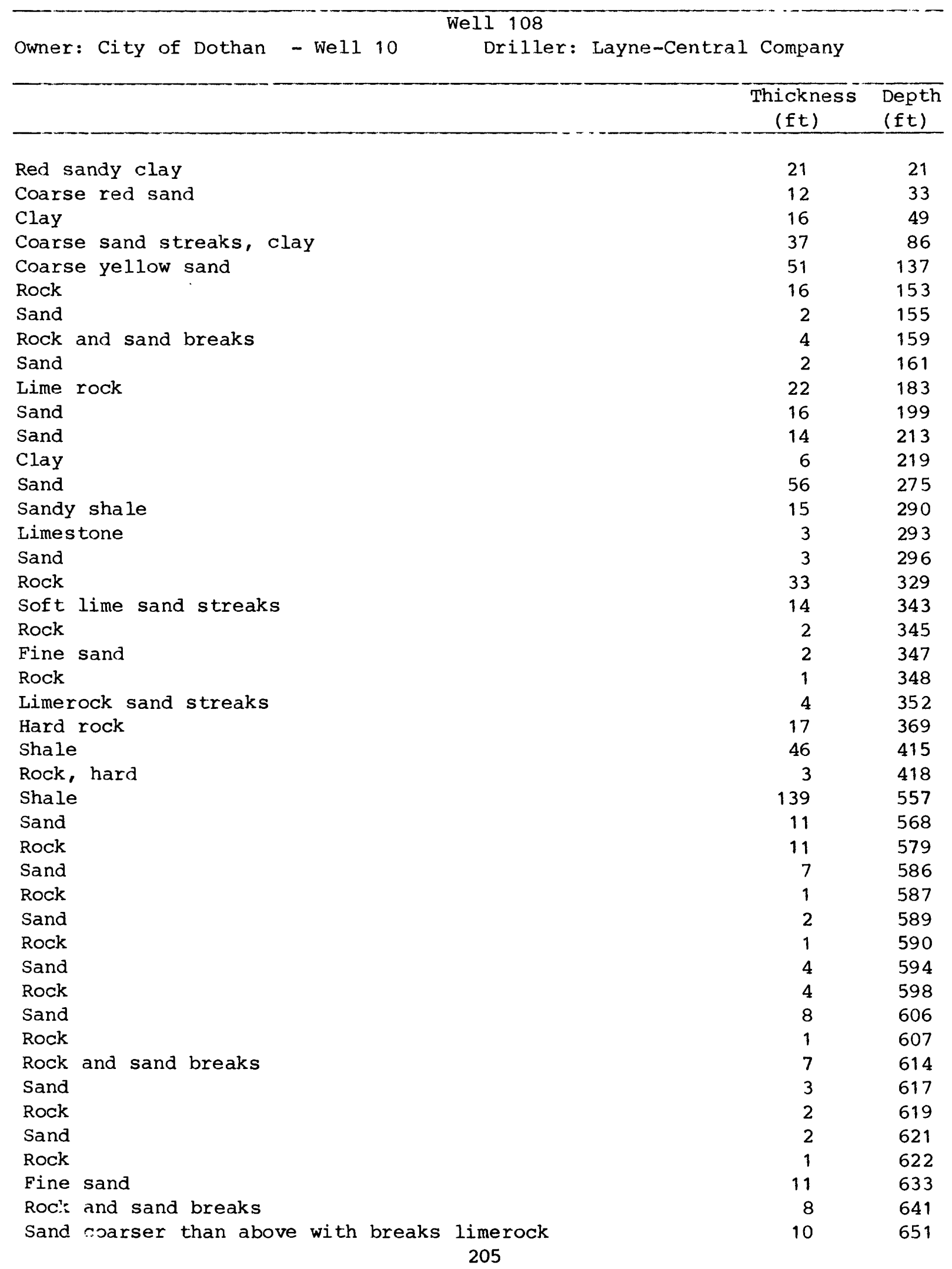


Table 3.--Driller's logs of wells in the Fort Rucker area--Continued

\begin{tabular}{|c|c|c|}
\hline & $\begin{array}{l}\text { Thickness } \\
\text { (ft) }\end{array}$ & $\begin{array}{l}\text { Depth } \\
(\mathrm{ft})\end{array}$ \\
\hline Rock & 2 & 653 \\
\hline Sand & 4 & 657 \\
\hline Rock & 1 & 658 \\
\hline Sand & 2 & 660 \\
\hline Limerock & 43 & 703 \\
\hline Limerock breaks red sand & 9 & 712 \\
\hline Pack sand & 13 & 725 \\
\hline Rock & 3 & 728 \\
\hline Pack sand & 44 & 772 \\
\hline Hard sandy lime and shale & 18 & 790 \\
\hline
\end{tabular}


Table 3.--Driller's logs of wells in the Fort Rucker area--Continued

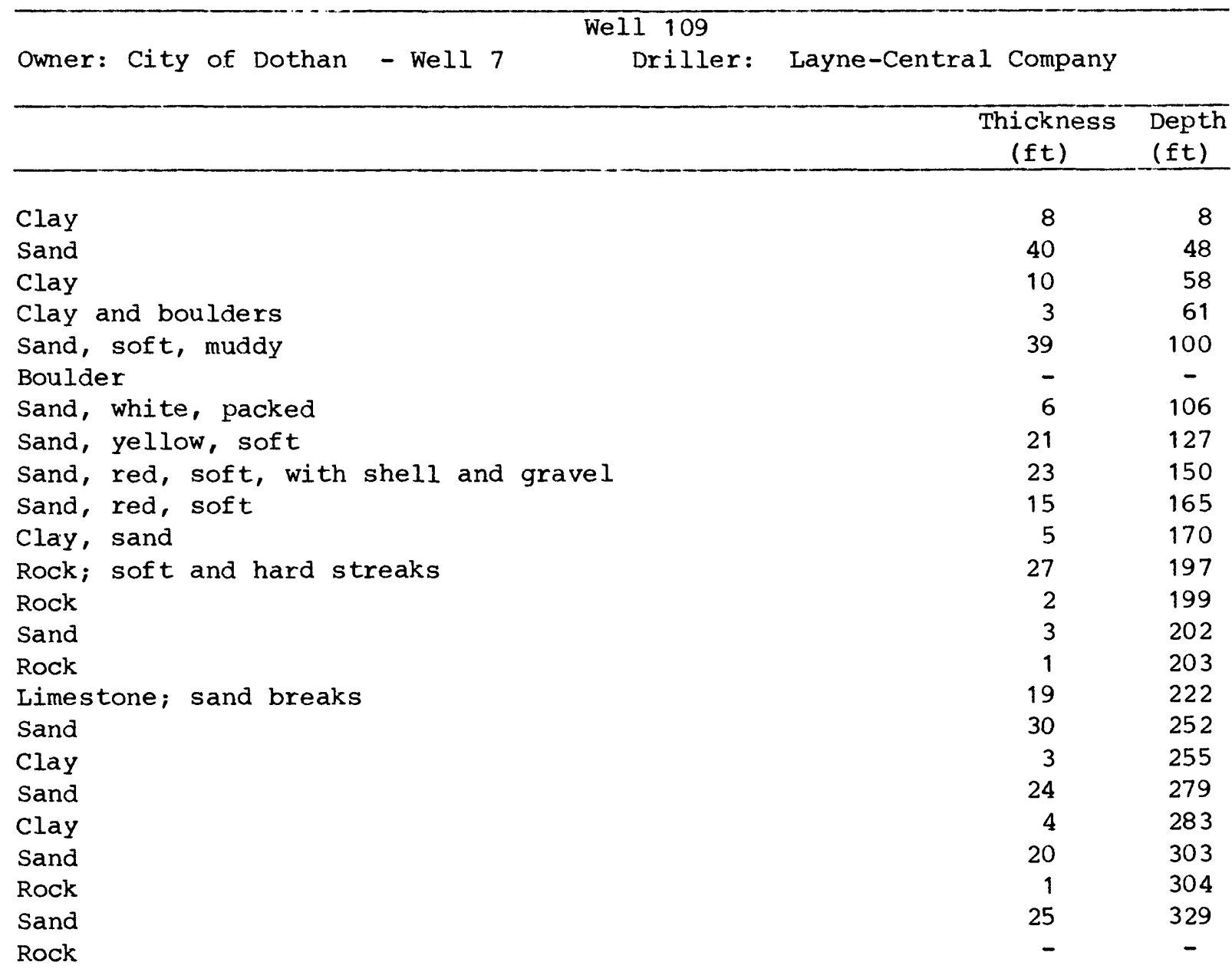


Table 3.--Driller's logs of wells in the Fort Rucker area--Continued

\begin{tabular}{|c|c|c|}
\hline $\begin{array}{l}\text { Owner: City of Dothan - Well } 11 \quad \text { Dell } 110 \\
\text { Driller: Layne- }\end{array}$ & I Company & \\
\hline & $\begin{array}{l}\text { Thickness } \\
\text { (ft) }\end{array}$ & $\begin{array}{l}\text { Depth } \\
(\mathrm{ft})\end{array}$ \\
\hline Clay & 52 & 52 \\
\hline $\begin{array}{l}\text { Limestone, lost returns pumped cement in it, } \\
\text { and finally set } 24 \mathrm{in.} \text { surface casing }\end{array}$ & 38 & 90 \\
\hline Packed sand with soft streaks & 53 & 143 \\
\hline Packed sand & 20 & 163 \\
\hline Rock & 1 & 164 \\
\hline Clay & 4 & 168 \\
\hline Limerock & 27 & 195 \\
\hline Sand and lime breaks & 34 & 229 \\
\hline Clay and lime breaks & 51 & 280 \\
\hline Sandy clay & 12 & 292 \\
\hline Sand & 6 & 298 \\
\hline Sandy clay & 25 & 323 \\
\hline Limestone & 95 & 418 \\
\hline Clay & 125 & 543 \\
\hline Blue and white clay & 63 & 606 \\
\hline Hard shale & 19 & 625 \\
\hline Limerock & 5 & 630 \\
\hline Dark gray sand & 2 & 632 \\
\hline Limerock & 3 & 635 \\
\hline Dark gray sand & 11 & 646 \\
\hline Dark gray sand & 12 & 658 \\
\hline Limerock & 3 & 661 \\
\hline Sand & 2 & 663 \\
\hline Limerock & 1 & 664 \\
\hline 3 to $4 \mathrm{ft}$ streaks sand with 6 to $8 \mathrm{in}$. breaks limerock & 70 & 734 \\
\hline Sand and limerock & 70 & 804 \\
\hline Brown sand and small rock breaks & 31 & 835 \\
\hline Blue shale & 15 & 850 \\
\hline
\end{tabular}


Table 3.--Driller's logs of wells in the Fort Rucker area--Continued

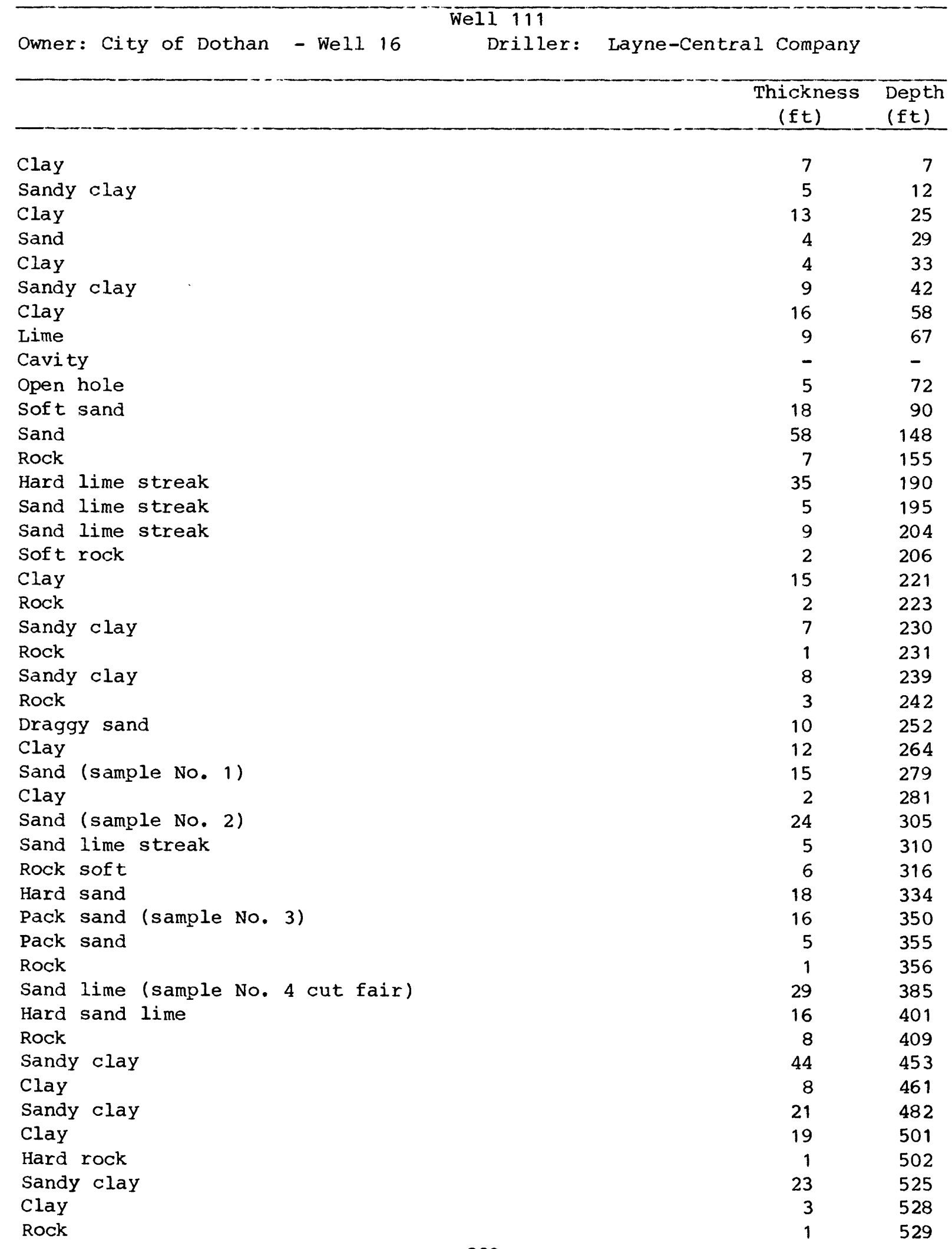


Table 3.--Driller's logs of wells in the Fort Rucker area--Continued

\begin{tabular}{|c|c|c|}
\hline & $\begin{array}{l}\text { Thickness } \\
\text { (ft) }\end{array}$ & $\begin{array}{l}\text { Depth } \\
\text { (ft) }\end{array}$ \\
\hline Sandy clay & 12 & 541 \\
\hline Rock & - & - \\
\hline Sandy clay & 10 & 551 \\
\hline Rock & - & - \\
\hline Clay & 5 & 556 \\
\hline Rock & 1 & 557 \\
\hline Sandy clay & 35 & 592 \\
\hline Green sand (sample No. $51 / 8$ in.) & 24 & 616 \\
\hline Rock & 1 & 617 \\
\hline Draggy green sand & 5 & 622 \\
\hline Hard lime rock & 6 & 628 \\
\hline Packed sand & 10 & 638 \\
\hline Sandy lime (sample No. $61 / 2$ in. mud) & 5 & 643 \\
\hline Hard lime sand & 17 & 660 \\
\hline Pack sand gray (sample No. 7 1/4 in. mud) & 4 & 664 \\
\hline Pack sand lime (sample No. $81 / 8$ in. mud) & 16 & 680 \\
\hline Clay lime & 20 & 700 \\
\hline Fine sand (sample No. 9) & 11 & 711 \\
\hline Hard lime sandy clay (sample No. 10) & 22 & 733 \\
\hline Hard lime sandy clay & 23 & 756 \\
\hline Same & 28 & 784 \\
\hline Pack sand 3 small lime breaks (sample No. 11 1/3 in. mud) & 20 & 804 \\
\hline Lime clay & 63 & 867 \\
\hline
\end{tabular}


Table 3.--Driller's logs of wells in the Fort Rucker area--Continued

\begin{tabular}{|c|c|c|}
\hline Owner: City of Dothan - Well 21 & Layne-Central Company & \\
\hline & $\begin{array}{l}\text { Thickness } \\
\text { (ft) }\end{array}$ & $\begin{array}{l}\text { Depth } \\
\text { (ft) }\end{array}$ \\
\hline Sandy clay & 12 & 12 \\
\hline Sand & 14 & 26 \\
\hline Pink clay & 20 & 46 \\
\hline Sand & 6 & 52 \\
\hline Clay & 33 & 85 \\
\hline Lime, hard & 16 & 101 \\
\hline Lime, hard and soft & 28 & 129 \\
\hline Sand and soft lime & 42 & 171 \\
\hline Rock & 2 & 173 \\
\hline Hard lime, blue clay & 13 & 186 \\
\hline Sand and blue clay streaks & 14 & 200 \\
\hline Soft lime with hard streaks & 69 & 269 \\
\hline Hard lime & 2 & 271 \\
\hline Lime rock & 20 & 291 \\
\hline Sand, gray & 27 & 318 \\
\hline Sand, gray & 16 & 334 \\
\hline Rock & 1 & 335 \\
\hline Sand, gray & 6 & 341 \\
\hline Sand, gray & 13 & 354 \\
\hline Sand lime and clay streaks & 47 & 401 \\
\hline Sand and gray & 10 & 411 \\
\hline Sand and limes streaks & 45 & 456 \\
\hline Lime rock & 2 & 458 \\
\hline Hard and soft lime & 38 & 496 \\
\hline Rock & 2 & 498 \\
\hline Clay & 39 & 537 \\
\hline Rock, hard lime & 8 & 545 \\
\hline Clay and shale & 100 & 645 \\
\hline Sand, green & 15 & 660 \\
\hline Sand, green & 8 & 668 \\
\hline Hard lime, clay and sand streaks & 14 & 682 \\
\hline Lime and sand streaks & 8 & 690 \\
\hline Sand, green & 14 & 704 \\
\hline Sand with lime breaks, gray sand & 6 & 710 \\
\hline Rock, hard & 1 & 711 \\
\hline Sand with lime breaks, gray sand & 16 & 727 \\
\hline Sand lime breaks with clay streaks & 22 & 749 \\
\hline Sand and lime streaks & 3 & 752 \\
\hline Hard clay and lime & 19 & 771 \\
\hline Hard clay and sandy lime & 43 & 814 \\
\hline Clay & 45 & 859 \\
\hline
\end{tabular}


Table 3.--Driller's logs of wells in the Fort Rucker area--Continued

\begin{tabular}{lrrr}
\hline Owner: U.S. Army & Well $\begin{array}{c}114 \\
\text { Allen Field }\end{array}$ & $\begin{array}{c}\text { Thickness } \\
\text { (ft) }\end{array}$ & $\begin{array}{c}\text { Depth } \\
\text { (ft) }\end{array}$ \\
\hline & & \\
Sandy clay & 15 & 15 \\
Gravel & 30 & 45 \\
Soft chalk & 25 & 70 \\
Stiff clay & 30 & 100 \\
Clay rock & 10 & 110 \\
Clay marl & 40 & 150 \\
Rock & 2 & 152 \\
Marl & 3 & 155 \\
Rock & 1 & 156 \\
Sandy marl & 12 & 168 \\
Rock & 2 & 170 \\
Mucky sand & 10 & 180 \\
Soft marl & 15 & 195 \\
Marl rock & 22 & 217 \\
Hard rock & 5 & 222 \\
Sandy marl & 23 & 245 \\
Marl & 25 & 270 \\
Rock & 5 & 275 \\
Marl & 100 & 375 \\
Sandy marl & 10 & 385 \\
Sand & 10 & 395 \\
Rock & 28 & 397 \\
Sand & & 425
\end{tabular}


Table 3.--Driller's logs of wells in the Fort Rucker area--Continued

\begin{tabular}{lrr}
\hline Owner: Mount Pleasant - Battens Crossroads & $\begin{array}{c}\text { Well } \\
\text { Water Authority }\end{array}$ & Driller: Foy English Drilling Co. \\
& $\begin{array}{r}\text { Thickness } \\
\text { (ft) }\end{array}$ & $\begin{array}{c}\text { Depth } \\
\text { (ft) }\end{array}$ \\
\hline & & \\
Clay & 20 & 20 \\
Sand and clay & 120 & 140 \\
Clay and rock & 20 & 160 \\
Sand and clay & 30 & 190 \\
Sand, marl, and rock & 40 & 230 \\
Sand and marl & 60 & 290 \\
Marl and rock & 20 & 310 \\
Marl & 320 & 630 \\
Limestone and sand & 40 & 670 \\
Limestone & 142 & 812
\end{tabular}


Table 3.--Driller's logs of wells in the Fort Rucker area--Continued

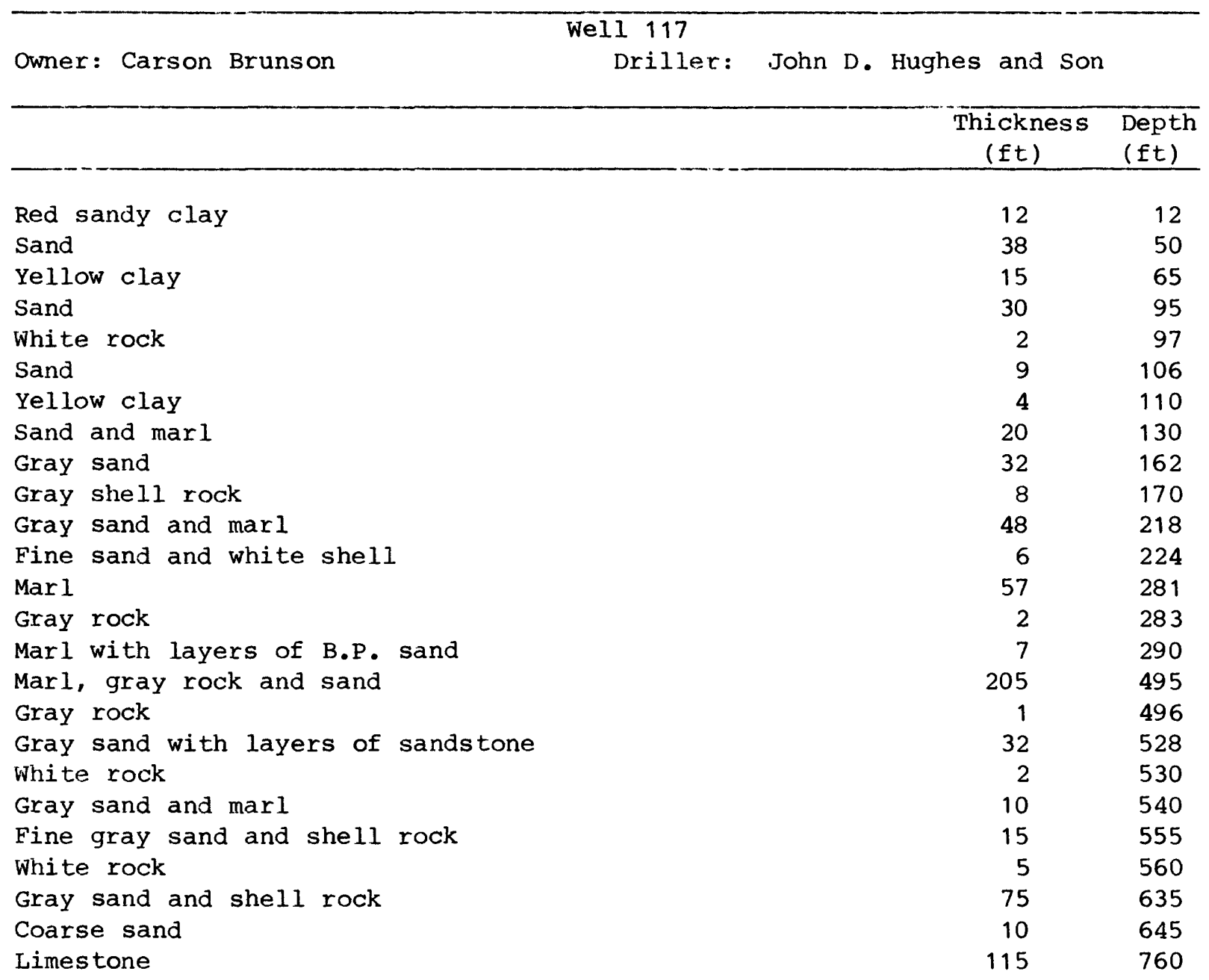


Table 3.--Driller's logs of wells in the Fort Rucker area--Continued

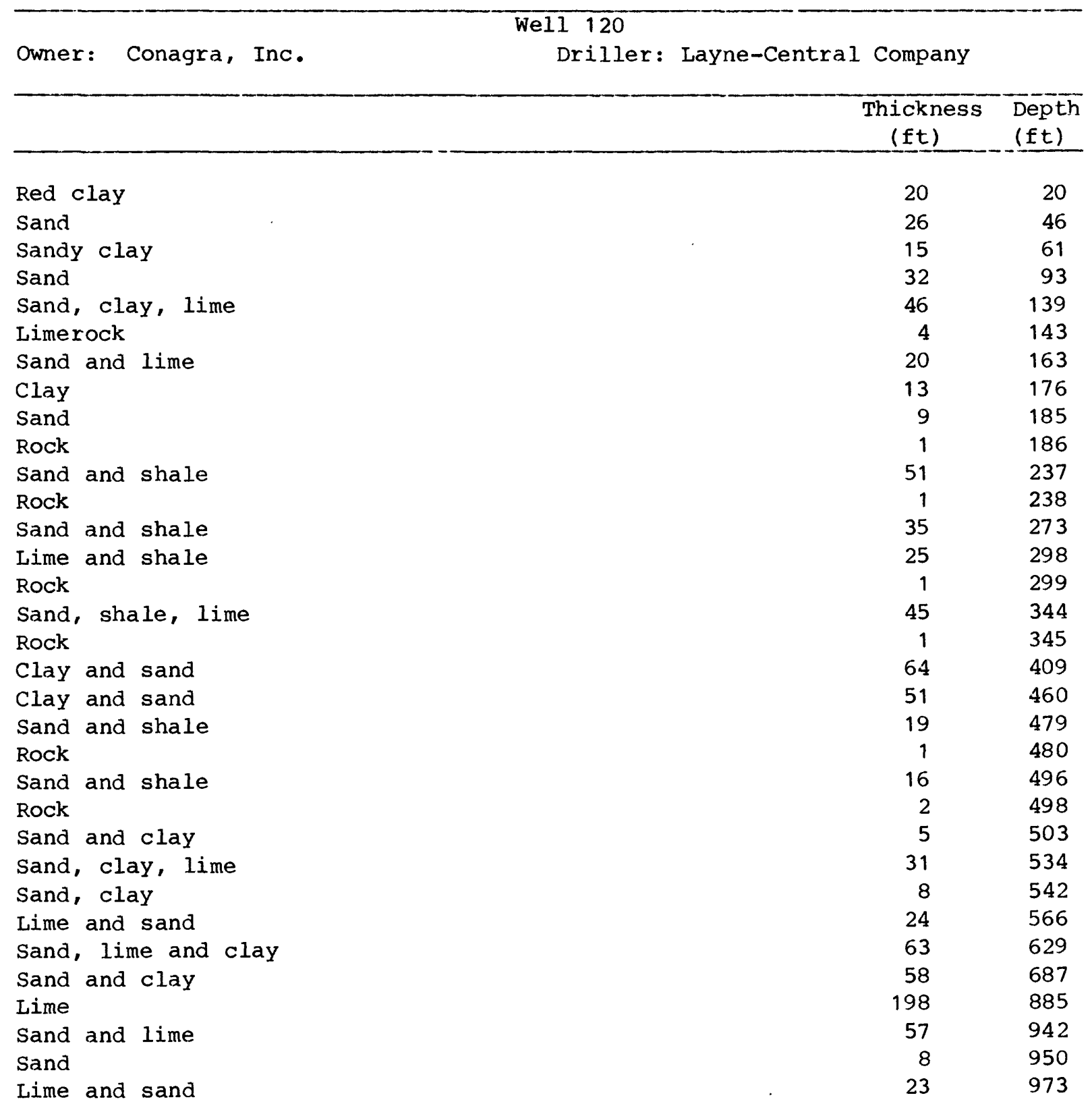


Table 3.--Driller's logs of wells in the Fort Rucker area--Continued

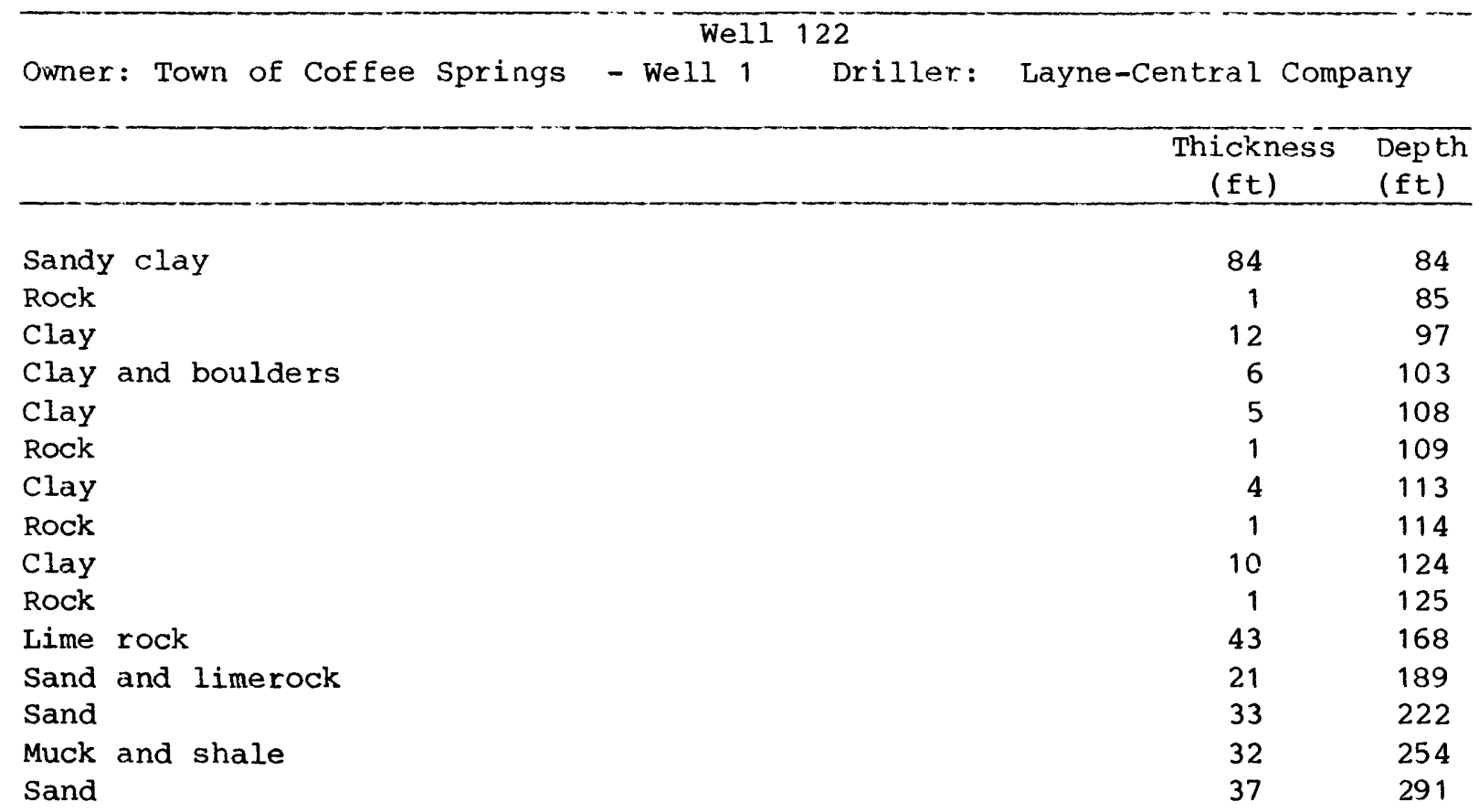


Table 3.--Driller's logs of wells in the Fort Rucker area--Continued

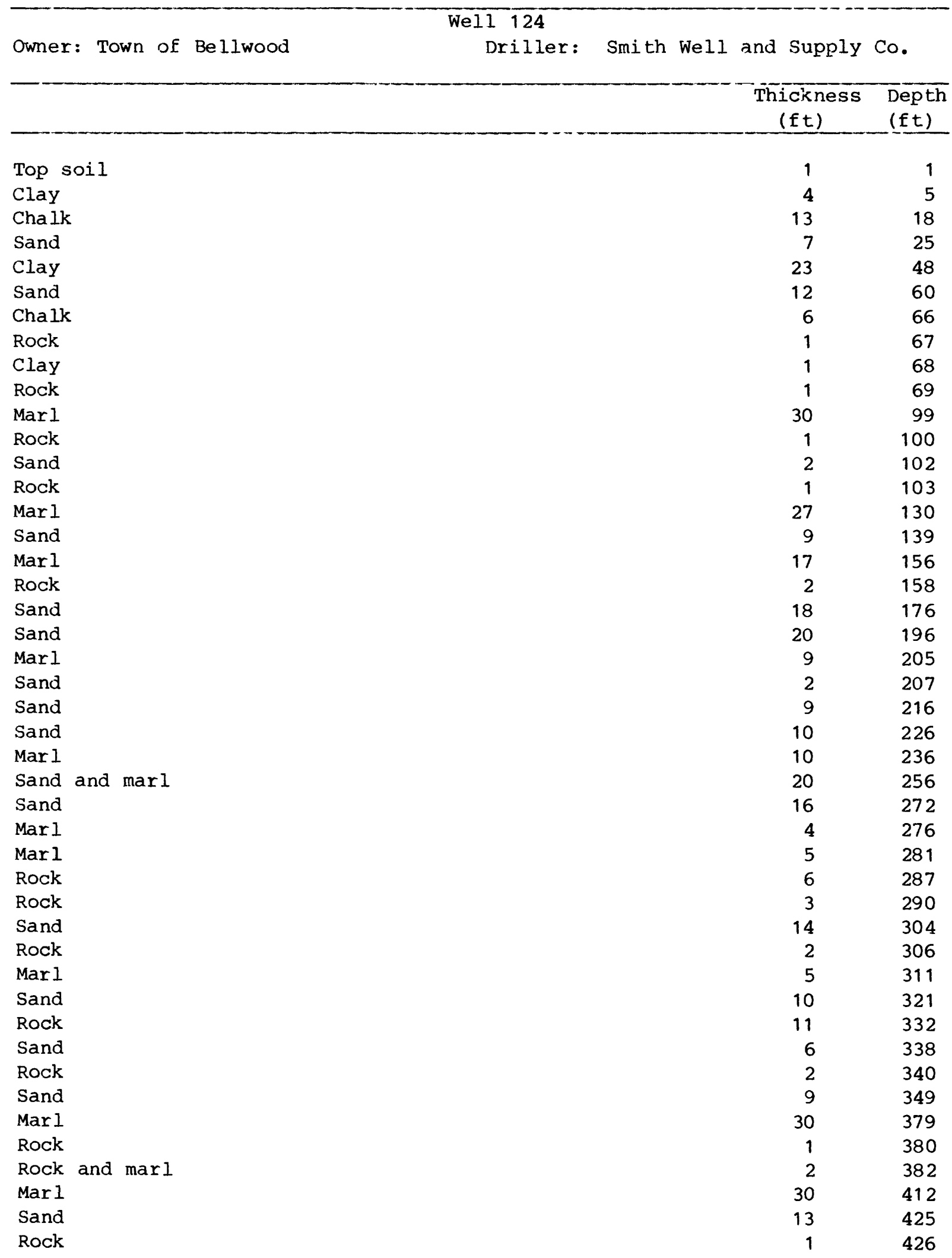


Table 3.--Driller's logs of wells in the Fort Rucker area--Continued

Well 124

Thickness

$(f t)$

Depth

Sand

Marl

Marl

Rock

Marl

Marl

Sand

Rock

Sand

Sand

$\begin{array}{rr}1 & 427 \\ 1 & 436 \\ 30 & 466 \\ 2 & 468 \\ 8 & 476 \\ 30 & 506 \\ 6 & 512 \\ 1 & 513 \\ 23 & 536 \\ 20 & 556\end{array}$


Table 3.--Driller's logs of wells in the Fort Rucker area--Continued

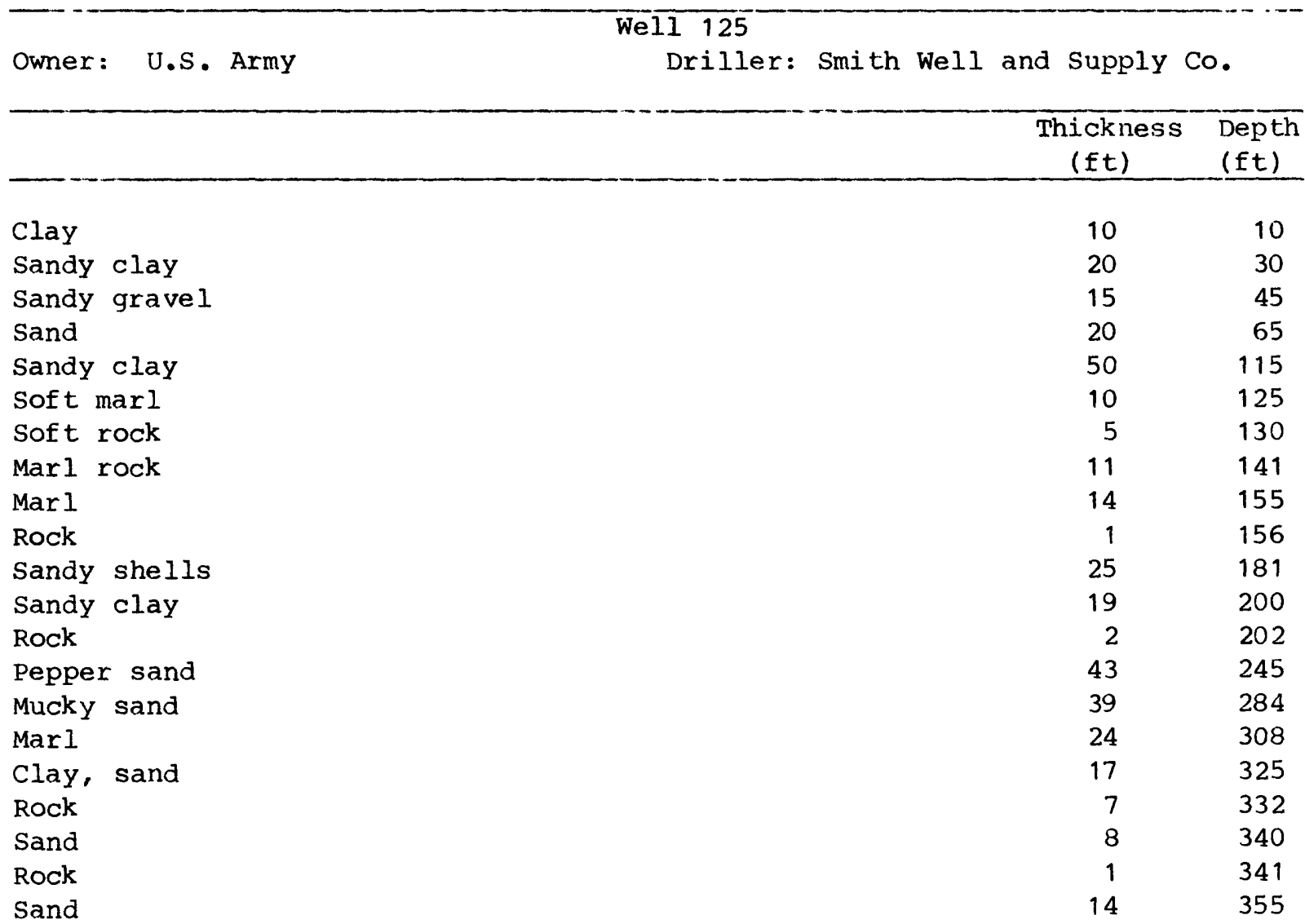


Table 3.--Driller's logs of wells in the Fort Rucker area--Continued

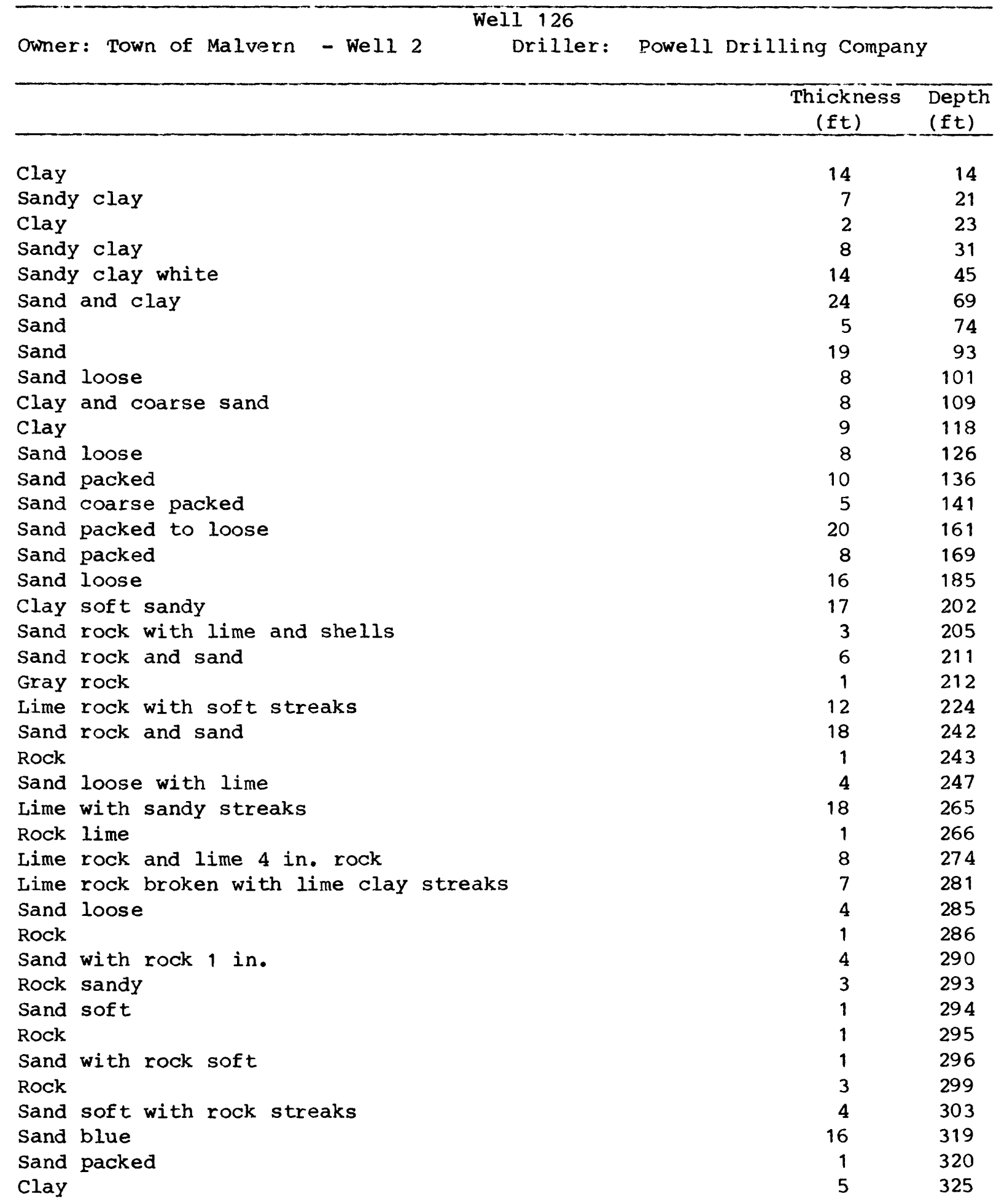


Table 3.--Driller's logs of wells in the Fort Rucker area--Continued

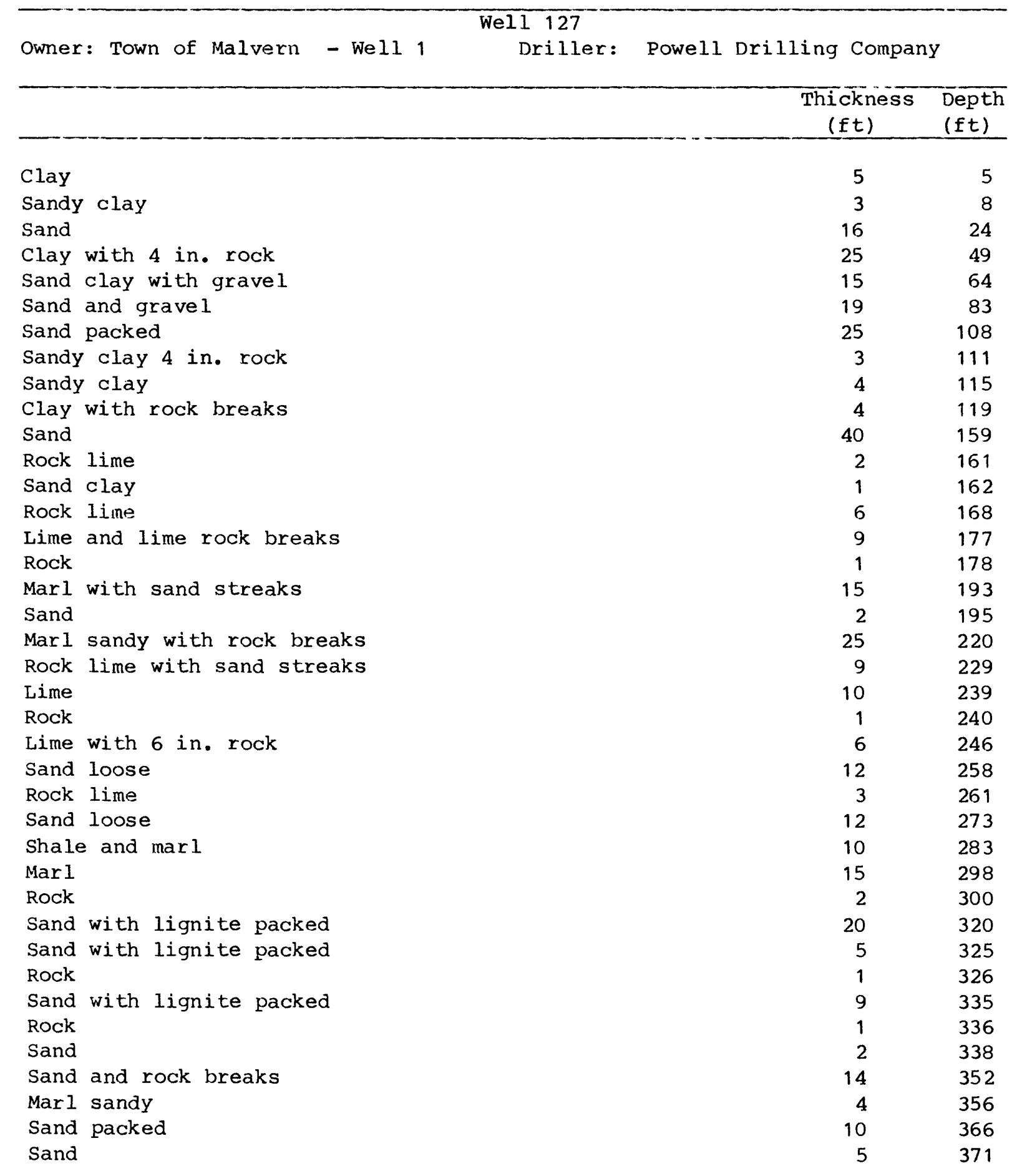

